Universidade de São Paulo

Faculdade de Economia, Administração e Contabilidade

Departamento de Economia

\title{
Duplo Caráter do Trabalho, Valor e ECONOMia CAPITALista
}

Jõ̃o MACHAdo Borges NeTO

Orientadora: Profa. Dra. Leda Maria Paulani

São Paulo

2002 


\section{DuPlo Caráter do Trabalho, VAlOR E ECONOMia Capitalista}

\section{JoÃo MACHAdo Borges Neto}

Orientadora: Profa. Dra. Leda Maria Paulani

Tese apresentada à Faculdade de Economia, Administração e Contabilidade da Universidade de São Paulo para a obtenção do título de Doutor em Economia

São Paulo 
Para meu pai, Jarbas (in memoriam)

Para minha mãe, Mercês

Para Maria Alice, minha companheira

Para meus filhos, Ana e Diogo 


\section{AGRADECIMENTOS}

Agradeço, em primeiro lugar, à minha orientadora, Profa. Leda Maria Paulani, pela rica discussão do tema da dissertação e pelas numerosas e úteis sugestões; suas aulas, bem como as discussões que tivemos, exerceram uma influência decisiva para o desenvolvimento de muitas das idéias expostas neste trabalho. Do mesmo modo, agradeço aos membros da Banca do Exame de Qualificação, Prof. Paul Singer e Prof. João Sayad, por seus comentários generosos e pelas sugestões que permitiram aperfeiçoar ou corrigir alguns aspectos da tese. Além disto, a oportunidade de ter sido aluno de ambos revelou-se extremamente feliz para a abertura de horizontes teóricos, em parte refletidos aqui.

Foi fundamental para o desenvolvimento deste trabalho a convivência com os colegas e amigos do Departamento de Economia da FEA-PUC/SP. Além dos docentes do Departamento, também os alunos me ajudaram a esclarecer minhas idéias sobre a economia marxista. A redação deste trabalho se beneficiou da oportunidade de tratar deste assunto com as numerosas turmas de Economia Política que tive desde meu ingresso na PUC. Pude contar, ainda, com a concessão por parte da PUC-SP de dez horas-aula para as atividades do doutorado, durante vinte e quatro meses.

A convivência que tive durante os anos de estudo no IPE da FEA-USP foi sempre uma ocasião de estímulo intelectual, cuja importância para o desenvolvimento das idéias aqui expostas deve ser registrada; expresso meu reconhecimento a todos os seus professores e funcionários, bem como aos colegas.

Tenho de agradecer também o apoio que sempre tive de minha família. O esforço considerável que foi necessário para redação desta tese não teria sido possível sem ele. Agradeço modo especial à minha companheira, Maria Alice.

Com todos devo dividir os eventuais méritos deste trabalho. Naturalmente, as falhas remanescentes são de minha inteira responsabilidade. 


\section{RESUMO}

Este trabalho expõe a estrutura conceitual básica da economia marxista, discute sua coerência à luz do debate das principais críticas que lhe são feitas, e procura mostrar sua utilidade para a compreensão da economia capitalista atual.

Isto é feito a partir de uma chave de interpretação que destaca duas questões: o duplo caráter do trabalho produtor de mercadorias, e a caracterização do trabalho abstrato como substância social do valor. Uma das idéias centrais deste trabalho é a afirmação de que esta abordagem permite tratar o dinheiro, o capital e a dinâmica da economia capitalista de modo mais realista e adequado que outras vertentes teóricas.

A solução dada por Marx para a transformação dos valores em preços de produção é um dos principais exemplos do emprego da concepção do valor como substância social, e ao mesmo tempo uma das construções mais criticadas na economia marxista; por isto esta discussão tem aqui um lugar central.

Este trabalho procura ainda mostrar a utilidade analítica do quadro conceitual da economia marxista para tratar diversas questões atuais da economia capitalista, como o intercâmbio desigual. Argumenta, ainda, que este quadro é um ponto de partida capaz de recolher contribuições teóricas originadas de outras abordagens. 


\begin{abstract}
This work exposes the basic conceptual structure of Marxian economics, discusses its coherence in the light of the main criticisms made to it, and tries to show its utility to the comprehension of today's capitalist economy.

This is done taking a key that stresses two questions: the dual character of the labor that produces commodities, and the characterization of abstract labor as substance of value. One of the main ideas of this work is the statement that this approach allows us to treat money, capital and the capitalist economy's dynamics in a more realist and proper way than other theoretical approaches.

Marx's solution to the transformation of commodities values into production prices is one of the main examples of value as a social substance, and also is one of the more criticized constructs of Marxian economics; for that reason, this discussion has here a central place.

This work still tries to show the analytical utility of the conceptual framework of Marxian economics to treat several questions of today's capitalist economy, as unequal exchange. It still argues that this framework is a foundation able to gather theoretical contributions from other approaches.
\end{abstract}




\section{SUMÁRIO}

INTRODUÇÃO

CAPÍTULO 1 - DA MERCADORIA AO CAPITAL: CONSTITUIÇÃo E DESENVOLVIMENTO DE UMA SUBSTANCIA SOCIAL SEMOVENTE

1.1 - INTRODUÇÃO

1.2 - MERCADORIA E DINHEIRO 9

1.2.1 - Mercadoria, valor e trabalho 9

1.2.2 — Forma do valor e dinheiro $\quad 15$

1.2.3 - Fetichismo da mercadoria e especificidade histórica da economia mercantil 22

1.2.4 - Desenvolvimento das trocas e da produção de mercadorias 27

1.3 - TEMPO DE TRABALHO, DINHEIRO E ACUMULAÇ̃̃O 32

1.3.1 - Distinção entre tempo de trabalho, valor e preço 32

1.3.2 - Entesouramento e acumulação

1.4 - O CAPITAL 39

1.4.1 - Substância do valor e capital

1.4.2 - O capital como sujeito $\quad 43$

1.4.3 - Valorização do capital e subsunção real do trabalho ao capital 44

1.4.4 - Negação da propriedade baseada no próprio trabalho 49

1.5 - A ESPECIFICIDADE DA TEORIA DA MERCADORIA, DO VALOR, DO DINHEIRO E DO CAPITAL DE

MARX $\quad 54$

1.5.1 — Especificidades da economia de Marx 54

1.5.2 - Especificidade da teoria da mercadoria e do dinheiro 55

1.5.3 - A distinção entre valor e preço $\quad 58$

1.5.4 - Valor, capital e dinâmica

CAPÍtulo 2 - Questões de Método

2.1 - INTRODUÇÃO

2.2 - O MÉTODO DE O CAPITAL

2.2.1 — "O método da Economia Política": do abstrato ao concreto 61

$\begin{array}{ll}2.2 .2 \text { - A Seção I } & 68\end{array}$

2.2.3 - Aparência e essência em O Capital $\quad 80$

2.2.4 - As alterações no Plano da Crítica da Economia Política 83

2.2.5 - Outro começo; outro método? 86

2.2.6 - A dialética 93

2.2.7 - A estrutura dos níveis de abstração em O Capital 95 
2.4 - A QUESTÃO DA “PROVA DO VALOR” 100

CAPÍTULO 3 - DUPLO CARÁTER do TRABALHO E SUBSTÂNCIA DO VALOR 103

$\begin{array}{ll}3.1 \text { - INTRODUÇÃO } & 103\end{array}$

3.2 - O DUPLO CARÁTER DO TRABALHO 104

3.2.1 — O "resultado crítico final de século e meio de pesquisas" 104

3.2.2 — Dualidade das categorias econômicas e especificidade histórica 106

3.2.3 - Substância social, dinheiro e capital 108

3.2.4 - A interação contraditória trabalho concreto x trabalho abstrato 109

3.2.5 - Trabalho, valor, improdutividade do capital e mais-valia 110

3.2.6 - Aspectos 'técnicos' vinculados ao duplo caráter do trabalho 113

3.3 - O TRABALHO ABSTRATO 114

3.3.1 - O que se exige do conceito 114

3.3.2 - Trabalho abstrato e generalização das trocas 119

$\begin{array}{ll}3.3 .3 \text { - A quantificação do trabalho abstrato } & 124\end{array}$

3.3.4 - Trabalho complexo / trabalho simples 132

3.3.5 - A sincronização dos trabalhos 135

3.3.6 - O reconhecimento social do trabalho 137

3.3.7 - O puro dispêndio produtivo de cérebro, músculos, nervos, mãos humanos 138

3.3.8 - Trabalho abstrato e valor: categorias da produção 144

3.3.9 - Trabalho abstrato e determinação social do valor $\quad 146$

3.4 - A SUBSTANNCIA DO VALOR 148

3.4.1 - Por que substância? $\quad 148$

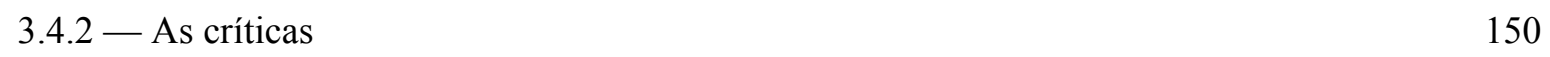

3.4.3 - Avaliação das críticas 154

$\begin{array}{ll}3.4 .4 \text { - Esta substância existe? } & 157\end{array}$

CAPÍTULO 4 - O PROBLEMA DA TRANSFORMAÇ̃̃o 159

4.1 - INTRODUÇÃO

4.2 - MARX E BORTKIEWICZ 161

4.2.1 - A solução de Marx 161

4.2.2 - A correção de Bortkiewicz e sua lógica 164

4.3 - A ABORDAGEM DO SISTEMA ÚNICO TEMPORAL 174

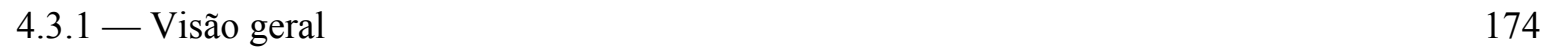

4.3.2 - Os níveis de abstração e a transformação 177

4.3.3 - Valores do capital constante, do capital variável, mais-valia e taxa de lucro 183 
4.3.5 - A transformação no movimento de produção e circulação dos capitais

4.4 - EXEMPLO NUMÉRICO DE UMA TRANSFORMAÇÃO COMPLETA DOS VALORES EM PREÇOS DE PRODUÇÃO EM UM SISTEMA ÚNICO TEMPORAL

4.5 - DIFERENÇAS ENTRE A ABORDAGEM DO SISTEMA ÚNICO TEMPORAL E A ABORDAGEM BORTKIEWICZIANA-SRAFFIANA

CAPÍTULO 5 - VALORES, PREÇOS E A LEI DO VALOR

5.1 - INTRODUÇÃO

\section{2 - TEMPO DE TRABALHO SOCIALMENTE NECESSÁRIO E MAIS-VALIA EXTRA}

5.2.1 - Referências sobre este tema em O Capital

5.2.2 - Produção de mais-valia extra a partir do trabalho de maior força produtiva

5.2.3 - Uma interpretação distinta

5.2.4 - Concorrência intra-setorial e progresso técnico

5.2.5 — A “difusão solidária" do aumento da produtividade do trabalho

5.3.2 - No Livro I de O Capital: preços e desvios dos preços em relação ao valor

5.3.5 - Desdobramentos ulteriores do conceito de preço 
CAPÍTUlo 6 - CONCLUSÃo: As CATEGORIAS da ECONOMIA MARXISTA DiANTE DE OUTRAS ABORDAGENS

6.1 - INTRODUÇÃO 262

6.2 - MERCADORIA, DINHEIRO E CAPITAL 262

6.2.1 - Duplo caráter do trabalho, substância do valor e dinheiro 262

6.2.2 - Capital e dinâmica $\quad 269$

6.2.3 - A determinação dos salários 275

6.2.4 - Diferenças entre preços e valores 276

6.3 - O DUPLO CARÁTER DO TRABALHO E AS CONTRADIÇÕES DO CAPITALISMO 277

6.3.1 - O caráter contraditório do progresso técnico 277

6.3.2 - A precariedade da mão invisível do mercado 278

6.4 - UM QUADRO TEÓRICO REALISTA, COERENTE, AMPLO E FLEXÍVEL 279

$\begin{array}{ll}\text { BIBLIOGRAFIA } & 281\end{array}$ 


\section{INTRODUÇÃO}

O objetivo geral da tese é expor a estrutura conceitual básica da economia marxista, discutir sua coerência à luz do debate das principais críticas que lhe são feitas, e mostrar sua utilidade para a compreensão da economia capitalista atual. Isto é feito a partir de uma chave de interpretação que destaca duas questões: o duplo caráter do trabalho produtor de mercadorias, e a caracterização do trabalho abstrato como substância social do valor.

O lugar central da dualidade do trabalho contido na mercadoria foi afirmado por Marx, que chegou a dizer que "esse é o ponto em torno do qual gira a compreensão da Economia Política", e além disso salientou ter sido quem a formulou pela primeira vez $[O$ Capital I-I: 49; El Capital I-I, p. 51] $]^{1}$.

A importância do tratamento do trabalho abstrato como substância social foi também enfatizada pelo próprio Marx. Como veremos no Capítulo 3, seção 3.4, ele usou diversas metáforas para representar a noção de substância do valor (gelatina de trabalho humano, objetividade fantasmagórica, cristal); além disto, esta noção ocupa um papel fundamental na sua construção teórica ${ }^{2}$.

O duplo caráter do trabalho que produz mercadorias e a caracterização do trabalho abstrato como substância do valor estão ademais na base de outra característica distintiva da economia de Marx - a análise da forma do valor —, a partir da qual desenvolveu sua teoria da gênese do dinheiro e afirmou a especificidade da economia capitalista. Como é amplamente conhecido, ele ressaltou tanto a importância desta questão quanto sua novidade $^{3}$.

\footnotetext{
${ }^{1}$ No Capítulo 3, seção 3.2, as diversas vezes em que Marx se referiu a este ponto são mencionadas, e ele é discutido de modo detalhado.

${ }^{2}$ Por exemplo, a análise da mais-valia independentemente de suas formas particulares (lucro, juro, renda fundiária), que Marx aponta como a segunda coisa que há de melhor no seu livro (a primeira é a análise do duplo caráter do trabalho) em carta a Engels de 24/08/1867 [Marx e Engels 1964, p. 174] repousa sobre a noção de uma substância do valor.

3 “Aqui cabe, no entanto, realizar o que não foi jamais nem tentado pela economia burguesa, isto é, comprovar a gênese dessa forma dinheiro, ou seja, acompanhar o desenvolvimento da expressão do valor
} 
Destas questões, a única incorporada de modo geral nas interpretações da economia marxista é a da especificidade da economia capitalista ${ }^{4}$. Em menor medida, a originalidade de sua teoria do dinheiro também tem sido reconhecida - embora o vínculo desta questão com a do caráter do trabalho abstrato como substância social do valor não seja sempre assinalado.

Nas últimas décadas, a importância do duplo caráter do trabalho que produz mercadorias na estrutura conceitual da economia marxista tem sido reconhecida, na forma de uma superação das interpretações do conceito de trabalho abstrato que tendem a banalizálo. A discussão do caráter do trabalho abstrato leva de modo quase direto à questão da substância do valor. Mas, em geral, não se vai além de uma menção a este tema. Em particular, segundo o meu conhecimento, o caminho de partir da atribuição ao valor de uma substância social para expor a estrutura conceitual da economia marxista ainda não foi trilhado, ou pelo menos não da maneira proposta nesta tese ${ }^{5}$.

Naturalmente, isto não impede que este trabalho se referencie na obra de diversos autores. Isaac Rubin antecipou várias das questões tratadas aqui no seu estudo clássico, $A$

contida na relação de valor das mercadorias, se sua forma mais simples e sem brilho até a ofuscante forma dinheiro. Com isto desaparece o enigma do dinheiro" [O Capital I-I: 54; El Capital I-I, p. 59].

“É uma das falhas básicas da Economia Política clássica não ter jamais conseguido descobrir, a partir da análise da mercadoria, e mais especificamente, do valor das mercadorias, a forma valor, que justamente o torna valor de troca. (...) A forma valor do produto do trabalho é a forma mais abstrata, contudo também a forma mais geral do modo burguês de produção, que por meio disso se caracteriza como uma espécie particular de produção social e, com isso, ao mesmo tempo, como algo histórico" [O Capital I-I: 76, nota 32; El Capital I-I, pp. 98-9, nota 32].

${ }^{4} \mathrm{O}$ que não significa, é claro, que esta especificidade tenha sido sempre compreendida da mesma maneira.

${ }^{5}$ Há algumas críticas às categorias de Marx que enfatizam o seu tratamento da substância do valor; talvez o exemplo mais claro seja o de Philip Mirowski [1989, Capítulo 4]; outros autores que desenvolvem uma crítica semelhante serão citados na seção 3.4 do Capítulo 3. Por outro lado, Ruy Fausto, principalmente em Abstração Real e Contradição: sobre o Trabalho Abstrato e o Valor [Fausto, 1987c], destaca e defende a caracterização do trabalho abstrato como substância social do valor, respondendo a Cornelius Castoriadis; a argumentação desenvolvida nesta tese se apóia neste e em outros aspectos de seus trabalhos, como ficará claro nos Capítulos 2 e 3. Fausto se ocupa sobretudo com a coerência lógica das categorias de Marx, e não se centra no seu significado econômico. 
teoria marxista do valor [Rubin 1980]. O mesmo fizeram Roman Rosdolsky em seu monumental estudo da economia de Marx [Rosdolsky 2001] e Ernest Mandel [Mandel 1967; 1976; 1981 e 1985]. Mais recentemente, Moishe Postone, em Time, labor and social domination [Postone 1993], colocou no centro da sua interpretação das categorias marxistas tanto o duplo caráter do trabalho quanto o fato de o trabalho abstrato constituir uma substância social.

$\mathrm{O}$ interesse do tema desta tese foi-me sugerido pelo estudo do problema da transformação a partir da abordagem do chamado sistema único temporal, que realizei em minha dissertação de mestrado. Esta abordagem tem implicações importantes para a estrutura conceitual da economia marxista. Os autores que a desenvolveram (sobretudo Andrew Kliman e Ted McGlone, e Alan Freeman), e os que desenvolveram a abordagem do sistema único simultâneo, que tem com ela muitos pontos de contato (sobretudo Wolff, Roberts e Callari, e Fred Moseley) mencionaram várias destas implicações, mas não fizeram uma apresentação sistemática delas. Por outro lado, não há entre estes autores pleno acordo sobre as questões conceituais, e nenhum deles centrou sua argumentação nos temas da substância do valor ${ }^{6}$ ou do duplo caráter do trabalho. Assim, a exposição da estrutura conceitual da economia marxista realizada aqui, embora se relacione com vários desenvolvimentos teóricos realizados nas últimas décadas, pode reivindicar um grau significativo de originalidade.

Minha convicção do interesse desta apresentação da estrutura conceitual da economia marxista foi muito reforçada pelo estudo da economia neoclássica que realizei desde 1998, no quadro do programa de doutorado em Teoria Econômica do IPE. Este estudo não apenas me chamou a atenção para a dificuldade (e em grande medida, me convenceu da artificialidade) do tratamento do dinheiro e do capital (para citar dois conceitos que estão, ou deveriam estar, no centro de qualquer teoria da economia capitalista) feito pela economia neoclássica, mas também sugeriu hipóteses sobre o que há de especial na economia marxista que lhe permite tratar estes conceitos de uma maneira muito mais sólida.

A tese mostra, a partir da chave de interpretação mencionada, que a coerência da economia marxista pode ser reivindicada diante das principais críticas que lhe são feitas; e

\footnotetext{
${ }^{6}$ Tema que, como veremos, pode ser claramente associado à abordagem do Sistema Único Temporal.
} 
também que ela tem o mérito de reproduzir nos seus conceitos aspectos fundamentais da economia capitalista, com relação aos quais outras abordagens, e em particular a economia neoclássica, têm dificuldades claras. Voltando aos exemplos já citados, enquanto os conceitos de dinheiro e de capital têm sido a origem de importantes dores de cabeça para a economia neoclássica, para Marx, ao contrário, tanto o tratamento do dinheiro quanto o do capital desdobram-se logicamente, de forma natural, da duplicidade do caráter do trabalho e da especificidade do trabalho abstrato enquanto uma substância social. É este ponto de partida que lhe permite caracterizar o dinheiro como figura geral do valor, concretização material do trabalho humano abstrato, e o capital como uma substância semovente, que se conserva e se expande através de metamorfoses, e que portanto é irredutível a uma coleção de "bens de capital" heterogêneos; e que, além disto, se torna sujeito, e faz de sua valorização a finalidade do processo econômico.

Ao longo da tese, e especialmente no Capítulo 6, serão feitas algumas comparações entre a economia marxista aqui interpretada e outras abordagens. O objetivo disto não é, contudo, realizar uma comparação sistemática entre as várias abordagens, o que seria sem dúvida muito interessante e útil, mas exigiria uma tese muito mais ambiciosa do que esta; e não é tampouco fazer propriamente uma crítica da economia neoclássica ou de outras abordagens. É apenas o de ressaltar características da abordagem marxista.

Um dos objetivos da tese é argumentar em favor das categorias econômicas de Marx como possivelmente o melhor ponto de partida existente para a análise da economia capitalista, já que através delas traços fundamentais da sua natureza e da sua dinâmica são apreendidos teoricamente. Isto não significa, entretanto, que seja adotado aqui o ponto de vista de que "tudo já está em Marx". Isto seria claramente absurdo. Por mais genial que tenha sido, Marx não dispunha de muitos dos instrumentos analíticos de que dispomos hoje, nem da experiência histórica, nem teve conhecimento dos debates teóricos dos últimos cento e vinte anos, etc. Além disto, ele deixou sua obra econômica dramaticamente incompleta; não concluiu a redação dos três livros de $O$ Capital, e pretendia ainda redigir outros livros que integrariam seu projeto de Crítica da Economia Política ${ }^{7}$. A economia de Marx não pode ser para nós senão um ponto de partida.

\footnotetext{
${ }^{7}$ Há uma controvérsia sobre o grau de incompletude da obra de Marx, que será comentada brevemente no Capítulo 2, subseção 2.2.4.
} 
Se tomamos em consideração apenas os aspectos mais diretamente econômicos da obra de Marx $^{8}$, podemos até mesmo arriscar uma comparação ${ }^{9}$ : a relação que a economia marxista contemporânea pode ter com Marx é semelhante à que a economia neoclássica contemporânea tem com Walras. Parte importante do progresso teórico no campo neoclássico no século XX foi realizado a partir de reinterpretações ou reconceptualizações da economia walrasiana; além disto, as dificuldades teóricas apontadas acima, dentre outras, atestam que com toda certeza estas reconceptualizações não chegaram a seu termo, e vão continuar.

Este trabalho se concentra nos aspectos econômicos da obra de Marx. Isto seria legítimo, diante do propósito deste autor de realizar uma crítica da Economia Política?

O sentido básico desta crítica para Marx é o de mostrar que as categorias da Economia Política, percebidas por esta como trans-históricas, são na verdade específicas ao modo capitalista de produção, às suas relações de produção, e são expressões fetichizadas destas relações; mostrar como estas categorias se constituem apenas nestas condições historicamente específicas; a partir daí, desvendar as leis de desenvolvimento do modo capitalista de produção e demonstrar sua tendência à própria superação. Murray Smith diz com propriedade:

Se é possível reduzir os vários milhares de páginas dos muitos livros e manuscritos que compreendem a 'crítica da economia política' de Marx a um único tema, é certamente este: para Marx, o modo de produção capitalista (e, inter alia, sua 'lei de movimento') não é 'eterno', mas sujeito a limites históricos especificáveis, que é tarefa da ciência revelar [Murray Smith, 1994, p. 47].

O fato de Marx ter definido seus escritos econômicos como "crítica da economia política" não implica portanto:

1) Que ele deixe de se ocupar da análise do funcionamento da economia capitalista. $O$ que ele pretende é ir além disto, isto é, deixar claros os limites desta análise, explicitar que as leis que a ciência econômica formula sobre esta economia são específi-

\footnotetext{
${ }^{8} \mathrm{O}$ que implica reduzir muito o seu alcance, mas é justificado pelo caráter da discussão realizada aqui.

${ }^{9}$ Que, como toda analogia, tem limites claros, mas — admitindo que seja uma analogia pertinente — ajuda a esclarecer alguma coisa.
} 
cas, não valem para qualquer época histórica ou para quaisquer relações de produção.

2) Que ele afirme que a "economia política clássica" não tem elementos úteis para a compreensão do funcionamento da economia capitalista. Pelo contrário, ele avalia que a Economia Política clássica "investiga o nexo interno das condições de produção burguesas" [O Capital, I-I, p. 76, nota 32]. É coerente com isto julgar que também as correntes que podem ser consideradas sucessoras da Economia Política clássica podem contribuir de modo fundamental para a compreensão da economia capitalista.

Não é incompatível com a abordagem de Marx do estudo da economia capitalista, portanto, o propósito de avaliá-la justamente a partir de suas contribuições para a compreensão do funcionamento da economia capitalista; é este o ângulo privilegiado nesta tese.

O Capítulo 1 expõe as categorias centrais da economia marxista segundo a interpretação adotada, seguindo o desenvolvimento do argumento na obra fundamental de Marx, O Capital.

O Capítulo 2 trata de questões de método importantes para a compreensão das categorias da economia de Marx, e da interpretação seguida neste trabalho em particular; o Capítulo 3 esclarece os fundamentos desta interpretação.

O Capítulo 4, que se ocupa do chamado problema da transformação, tem um lugar central na tese. A solução dada por Marx para a transformação dos valores em preços de produção é um dos principais exemplos do emprego da concepção do valor como substância social; ao mesmo tempo, a convicção (muito difundida) de que esta solução é indefensável tem sido uma das bases da afirmação de que esta concepção do valor não se sustenta, e representa mesmo uma das debilidades principais da construção teórica de Marx. Como o capítulo argumenta que a solução proposta por Marx é perfeitamente satisfatória (ou pode ser considerada como o ponto de partida de um tratamento perfeitamente satisfatório da questão), ele funciona tanto como um exemplo das vantagens da concepção marxiana de valor quanto como um complemento indispensável da fundamentação desta concepção, realizada no Capítulo 3.

O Capítulo 5 tem um caráter distinto dos anteriores: mostra como o quadro conceitual da economia marxista, tal como interpretada neste trabalho, é analiticamente útil para 
tratar algumas questões importantes da economia capitalista contemporânea. Além disso, ajuda a esclarecer alguns aspectos das categorias de Marx.

Finalmente, o Capítulo 6 faz uma série de comparações entre a abordagem de Marx e outras abordagens, com o objetivo de chamar a atenção, em primeiro lugar, para alguns pontos-fortes do quadro conceitual marxiano e, em segundo lugar, para o fato de que vários destes pontos-fortes se relacionam diretamente com o duplo caráter do trabalho e com a concepção do valor como substância social.

\section{Nota sobre as citações}

As citações de $O$ Capital são feitas, salvo indicação explícita em contrário, com base na edição brasileira da Editora Nova Cultural, em cinco volumes. Além disto, foram incluídos os grifos que havia na primeira edição de $O$ Capital, reproduzidos a partir da edição em castelhano de Siglo Veintiuno Editores, em oito volumes (como informa o responsável por esta edição, Pedro Scaron, os grifos foram suprimidos das edições posteriores por razões puramente econômicas) [El Capital, I-I, p. XII]. Eventualmente, quando necessário para esclarecer certos aspectos do texto, foram utilizadas edições em outras línguas, inclusive a edição alemã.

No caso das obras de Marx, as referências bibliográficas são feitas com o nome da obra, e não pelo nome do autor e a data da edição utilizada. No caso de $O$ Capital, a indicação da obra é seguida pelo número do Livro e do Volume na edição brasileira da Nova Cultural; em seguida é citada, da mesma maneira, a edição de Siglo Veintiuno Editores. Naturalmente, $O$ Capital indica a edição brasileira e El Capital a edição em castelhano; Das Kapital indica a edição em alemão, e assim por diante.

Todas as citações feitas com base em obras em línguas estrangeiras foram traduzidas para o português por mim. 


\section{Capítulo 1 - Da mercadoria Ao CAPITAL: CONSTITUiÇÃo E DESENVOLVIMENTO DE UMA SUBSTÂNCIA SOCIAL SEMOVENTE}

\section{1 - INTRODUÇÃO}

Este capítulo expõe as categorias centrais da economia marxista, segundo a interpretação defendida na tese. Segue o desenvolvimento do argumento na obra principal de Marx, $O$ Capital, e é constituído basicamente por citações do seu texto ${ }^{1}$ (recorrendo eventualmente também a outras obras) e por comentários a ele. Desta maneira, fica claro que a interpretação defendida aqui encontra grande apoio no texto do próprio Marx, e é no mínimo perfeitamente compatível com ele. Esta preocupação não se deve à convicção de que uma formulação teórica mais próxima ao texto de Marx seja obrigatoriamente melhor do que uma mais distante. Seu motivo é, simplesmente, a avaliação de que, sendo a formulação proposta nesta tese muito próxima ao texto de Marx, isto deve ficar claro.

A seção 1.2 expõe os aspectos centrais dos dois primeiros capítulos do Livro I de $O$ Capital. A seção 1.3 destaca alguns aspectos do Capítulo III do mesmo Livro que se relacionam mais diretamente com o tema da tese. A seção 1.4 se ocupa do conceito de capital, abordando temas de diversos capítulos do Livro I; destaca aspectos da concepção de Marx que diferem bastante de qualquer outra abordagem, e que além disto não são os mais conhecidos. Finalmente, a seção 1.5 chama a atenção para algumas das especificidades da teoria econômica de Marx que emergem ao longo do capítulo.

Dois temas atravessam o capítulo: a dupla natureza das categorias próprias à economia capitalista, e o caráter de substância social assumido pelo valor. Este serve de fio condutor. Inicialmente, a análise da mercadoria leva à descoberta do duplo caráter do trabalho e da existência de uma substância do valor, o trabalho humano abstrato. Depois, a forma adequada de expressão desta substância é encontrada no dinheiro. Em seguida, a formação desta substância é explicada, como resultado da reificação de relações sociais na economia mercantil. Esta substância é gerada pela objetivação do trabalho humano no pro-

\footnotetext{
${ }^{1}$ Restringe-se quase exclusivamente ao Livro I, embora sejam feitas menções aos outros livros, quando temas do Livro I são retomados.
} 
cesso de produção, mas pode ser transferida na circulação, a partir de desvios dos preços com relação aos valores.

Como capital, esta substância adquire movimento, e um movimento próprio: tornase uma substância social semovente. Este movimento impõe sua finalidade e sua marca ao conjunto das relações da economia capitalista; o processo de produção é submetido à sua lógica; os indivíduos humanos são tornados órgãos seus. Em conclusão, as relações sociais que os produtores de mercadorias estabelecem criam um movimento que os domina.

\section{2 - MERCADORIA E DINHEIRO}

\subsection{1 - Mercadoria, valor e trabalho}

O ponto de partida de $O$ Capital é a análise da mercadoria, forma elementar em que se apresenta a riqueza nas sociedades em que domina o modo capitalista de produção. A mercadoria é um objeto útil produzido pelo trabalho humano ${ }^{2}$, reprodutível portanto, não destinado ao consumo do seu próprio produtor, mas à venda. Em primeiro lugar, Marx analisa o seu caráter enquanto objeto físico que satisfaz necessidades humanas.

A mercadoria é antes de tudo, um objeto externo, uma coisa, a qual pelas suas propriedades satisfaz necessidades humanas de qualquer espécie. (...) A utilidade de uma coisa faz dela um valor de uso. Essa utilidade, porém, não paira no ar. Determinada pelas propriedades do corpo da mercadoria, ela não existe sem o mesmo. O corpo da mercadoria mesmo, como ferro, trigo, diamante etc., é, portanto, um valor de uso ou bem. (...) Os valores de uso constituem o conteúdo material da riqueza, qualquer que seja a forma social desta. $\mathrm{Na}$ forma de sociedade por nós examinada, eles constituem, ao mesmo tempo, os portadores materiais do - valor de troca [O Capital I-I, pp. 45-6; El Capital I-I, pp. 43-4].

Assim é introduzido o conceito de valor de uso, enquanto corpo da mercadoria e conteúdo material da riqueza. Há um aspecto do argumento deste parágrafo que é importante destacar: ao dizer que a "utilidade (...) não paira no ar", que "determinada pelas propriedades do corpo da mercadoria, ela não existe sem o mesmo", Marx está afirmando que

\footnotetext{
${ }^{2}$ Também bens que não são produtos do trabalho podem tornar-se mercadorias. Esta questão será tratada adiante, na subseção 1.3.1. Por outro lado, “objeto" deve ser entendido aqui em sentido amplo: serviços podem também ser mercadorias.
} 
a utilidade só existe como utilidade específica. Uma "utilidade em geral" só pode ser concebida como uma abstração, um gênero que só existe realmente em objetos particulares como utilidade específica ${ }^{3}$.

Imediatamente após esta análise inicial da mercadoria enquanto valor de uso, Marx afirma que, "na forma de sociedade por nós examinada", os valores de uso são os portadores materiais do valor de troca. Com isto, evidencia-se que a mercadoria tem um duplo caráter, que aparece na contraposição valor de uso x valor de troca; ao mesmo tempo, é explicitado que também a riqueza, "na forma de sociedade por nós examinada", tem um duplo caráter: riqueza material x riqueza em valor de troca (também chamada de riqueza abstrata).

Prosseguindo na análise, Marx constata que

[o] valor de troca aparece, de início, como a relação quantitativa, a proporção na qual valores de uso de uma espécie se trocam contra valores de uso de outra espécie, uma relação que muda constantemente no tempo e no espaço. $\mathrm{O}$ valor de troca parece, portanto, algo casual e puramente relativo (...). [O Capital I-I: 46; El Capital: I-I: 45]

A aparência de algo casual e puramente relativo logo se desfaz, com base em uma constatação fundamental que Marx faz implicitamente: a de que as proporções de troca não são arbitrárias, mas seguem alguma regra; de fato, isto significa que não estamos tratando de uma troca eventual, mas de uma troca que já acontece regularmente. Nestas condições, podemos analisar as trocas possíveis de uma mercadoria, e concluir que cada mercadoria se troca por outros artigos em proporções diversas, mas determinadas. Logo, se cada mercadoria assume diversos valores de troca, eles devem expressar algo de comum. Deve haver um conteúdo comum aos diversos valores de troca. Portanto, "o valor de troca, só pode ser o modo de expressão, a 'forma de manifestação' de um conteúdo dele distinguível" [ $O$ Capital I-I: 46; El Capital: I-I: 45].

O que pode ser este conteúdo comum? Constatamos que

(...) não pode ser uma propriedade geométrica, física, química ou qualquer outra propriedade natural das mercadorias. Suas propriedades corpóreas só entram em consideração à

\footnotetext{
${ }^{3}$ Geoffrey Kay [1979], pp. 51-3, chama a atenção para esta questão. Marx argumentará adiante, como veremos, que o trabalho abstrato tem existência real, ao contrário do que acontece com a utilidade.
} 
medida que elas lhes conferem utilidade, isto é, tornam-nas valores de uso. Por outro lado, porém, é precisamente a abstração de seus valores de uso que caracteriza evidentemente a relação de troca das mercadorias. Dentro da mesma um valor de uso vale exatamente tanto quanto outro qualquer, desde que esteja disponível em proporção adequada. (...) Como valores de uso, as mercadorias são, antes de mais nada, de diferente qualidade, como valores de troca só podem ser de quantidade diferente, não contendo, portanto, nenhum átomo de valor de uso [O Capital I-I: 46-7; El Capital: I-I: 46].

A afirmação central deste parágrafo é: "salta à vista que é precisamente a abstração de seus valores de uso que caracteriza a relação de troca das mercadorias"4. A relação de troca nega os valores de uso. Assim, para encontrar o que há de comum nas mercadorias enquanto valores de troca, temos de deixar de lado seus valores de uso, e com eles todas as suas propriedades naturais ${ }^{5}$. O que resta, então, é seu caráter de produtos do trabalho; entretanto, é preciso atentar para o fato de que, na medida em que os produtos do trabalho deixam de serem considerados como valores de uso, sofrem uma mudança, e esta mudança se estende para os trabalhos que os produziram.

Entretanto, o produto do trabalho também já se transformou em nossas mãos. Se abstraímos seu valor de uso, abstraímos também os componentes e formas corpóreas que fazem dele valor de uso. Deixa já de ser mesa ou casa ou fio ou qualquer outra coisa útil. Todas as suas qualidades sensoriais se apagaram. Também já não é o produto do trabalho do marceneiro ou do pedreiro ou do fiandeiro ou de qualquer outro trabalho produtivo determinado. Ao desaparecer o caráter útil dos produtos do trabalho, desaparece o caráter útil dos trabalhos nele representados e desaparecem também, portanto, as diferentes formas concretas

\footnotetext{
${ }^{4}$ Nesta repetição foi feita uma pequena alteração na redação ("evidentemente" foi substituído por "salta à vista”, como está na edição Siglo Veintiuno), para tornar a frase mais elegante.

${ }^{5}$ Observemos que, para excluir a utilidade, ao lado de todas as propriedades naturais, como possível conteúdo comum, este raciocínio se apóia implicitamente no argumento desenvolvido antes, de que não existe uma "utilidade em geral", a não ser como abstração de gênero. Se existisse uma "utilidade em geral", ela poderia servir de base para a troca. Apenas a partir daí poderia ser examinado se, de fato, as mercadorias se trocam em proporções em que suas utilidades são igualadas; e poder-se-ia chegar ao artifício da "utilidade marginal". A objeção de Marx contra a possibilidade de explicar as proporções de troca a partir da utilidade é mais profunda do que o chamado "paradoxo da água e do diamante". Voltaremos a esta questão no Capítulo 3, subseção 3.3.1.
} 
desses trabalhos, que deixam de diferenciar-se uns dos outros para reduzir-se em sua totalidade a igual trabalho humano, a trabalho humano abstrato.

Consideremos agora os resíduos dos produtos do trabalho. Nada restou deles salvo uma mesma objetividade fantasmagórica, uma simples gelatina de trabalho humano indiferenciado, isto é, do dispêndio de força de trabalho humana, sem consideração pela forma como foi despendida. O que essas coisas ainda representam é apenas que em sua produção foi despendida força de trabalho humano, foi acumulado trabalho humano. Como cristalizações desta substância social comum a todas elas, são valores — valores mercantis [ $\mathrm{OCa}$ pital I-I, p. 47; El Capital: I-I, pp. 46-7].

O que há de comum, que se revela na relação de troca ou valor de troca da mercadoria é, portanto, seu valor [O Capital I-I, p. 47; El Capital, pp. I-I: 47].

Nesta passagem densa, a partir da idéia de que os valores de troca expressam um conteúdo comum, são introduzidos os conceitos de trabalho útil (ou concreto), de trabalho abstrato e de valor. O valor é o conteúdo comum aos valores de troca; ele é a cristalização de uma substância social, o trabalho abstrato. O trabalho abstrato é trabalho humano indiferenciado, dispêndio de força de trabalho humana, sem consideração pela forma como foi despendida; sua cristalização tem uma existência social objetiva, embora fantasmagórica (Marx fala de "uma mesma objetividade fantasmagórica"!). O valor de troca é a forma de manifestação do valor. Por isso, a mercadoria é uma unidade (contraditória) de valor de uso e valor, e não de valor de uso e valor de troca.

A argumentação de Marx para passar do valor de troca ao trabalho abstrato como substância do valor foi desenvolvida em cinco passos. Em primeiro lugar, ele afirmou que o valor de troca só pode ser manifestação de um conteúdo distinto dele (o que, como vimos, implica as pressuposições de que as proporções de troca não são arbitrárias, e portanto de que as trocas já adquiriram alguma regularidade); em segundo lugar, que este conteúdo, sendo algo homogêneo, não pode vir, de nenhuma maneira, do valor de uso, domínio da diversidade, negado na relação de troca (este argumento se baseia na inexistência real de uma "utilidade em geral"); em terceiro lugar, que só lhe resta vir do fato de serem as mercadorias produtos do trabalho; em quarto, que se abstraímos o valor de uso dos produtos do trabalho, fazemos desaparecer também o caráter útil dos trabalhos neles representados, e resta então apenas uma "objetividade fantasmagórica", o trabalho abstrato (enfatizemos que, com esta afirmação, Marx está implicitamente dizendo que há algo comum aos diversos trabalhos que não é uma mera abstração de gênero; este algo comum tem 
existência real, ainda que fantasmagórica!); o quinto passo é a conclusão do argumento: o valor é uma cristalização do trabalho nesta forma de trabalho abstrato, que se revela então como a substância social comum aos valores.

Voltaremos, nos Capítulos 2 e 3, à discussão do sentido desta argumentação, que tem aspectos que podem ser considerados insólitos. Por ora, enfatizemos apenas que, ao afirmar que o valor tem um conteúdo, que ele tem uma substância, que ele não é uma simples relação entre as mercadorias, Marx começa a desenvolver um tema que representa uma das características distintivas de sua abordagem.

$\mathrm{Na}$ seqüência da sua argumentação, Marx passa sem maiores dificuldades para a questão da determinação quantitativa do valor a partir do tempo de trabalho.

Como medir, então, a grandeza de seu valor? Por meio do quantum nele contido da "substância constituidora do valor", o trabalho. A própria quantidade de trabalho é medida pelo seu tempo de duração ... [O Capital I-I: 47; El Capital: I-I: 47-8].

Aqui, é claro, impõe-se esclarecer que

[sendo o] tempo de trabalho socialmente necessário (...) aquele requerido para produzir um valor de uso qualquer, nas condições dadas de produção socialmente normais, e com o grau social médio de habilidade e intensidade do trabalho (...), [é] apenas o quantum de trabalho socialmente necessário, ou o tempo de trabalho socialmente necessário para a produção de um valor de uso o que determina a grandeza de seu valor. A mercadoria individual vale aqui apenas como exemplar médio de sua espécie. (...) "Enquanto valores todas as mercadorias são apenas medidas determinadas de tempo de trabalho cristalizado" ${ }^{6}$ [ $O$ Capital I-I: 48; El Capital: I-I: 48-9].

Na segunda parte do capítulo, Marx retoma alguns pontos de sua argumentação, a partir de uma análise mais detalhada da dupla natureza do trabalho contido na mercadoria, "ponto crucial em torno do qual gira a compreensão da economia política" [O Capital I-I, p. 49; El Capital I-I, p. 51].

O trabalho útil (ou concreto) é

uma espécie determinada de atividade produtiva (...) determinada por seu fim, modo de operar, objeto, meios e resultado. [É] o trabalho cuja utilidade representa-se, assim, no va-

\footnotetext{
${ }^{6}$ Citação feita por Marx de sua própria obra, Para a Crítica da Economia Politica.
} 
lor de uso de seu produto ou no fato de que seu produto é um valor de uso... [O Capital I-I, p. 50; El Capital I-I, p. 51].

Tal como havia feito com relação aos valores de uso, Marx enfatiza a necessária especificidade do trabalho útil que os produz. Ao mesmo tempo, destaca a constituição de uma divisão social do trabalho.

$\mathrm{Na}$ totalidade dos vários tipos de valores de uso ou corpos de mercadorias aparece uma totalidade igualmente diversificada, de acordo com o gênero, espécie, família, subespécie, variedade de diferentes trabalhos úteis — uma divisão social do trabalho. (...) Numa sociedade cujos produtos assumem, genericamente, a forma de mercadoria, isto é, numa sociedade de produtores de mercadorias, desenvolve-se esta diferença qualitativa dos trabalhos úteis, executados independentemente uns dos outros, como negócios privados de produtores autônomos, num sistema complexo, numa divisão social do trabalho [O Capital I-I, p. 50; El Capital I-I, p. 52].

Esta existência de uma divisão social do trabalho, e portanto de uma interdependência entre os diversos produtores, implica que o trabalho tem um caráter social. Embora a divisão social do trabalho e a interdependência entre os produtores sejam reforçadas pelo desenvolvimento da produção mercantil, este caráter social pertence ao trabalho enquanto trabalho útil, enquanto trabalho que satisfaz necessidades humanas determinadas. (Por outro lado, veremos mais adiante que o trabalho produtor de mercadorias tem um caráter social num segundo sentido; também o caráter social do trabalho adquire uma dupla natureza.)

Além disso, enquanto trabalho útil, criador de valores de uso, o trabalho é uma condição de existência do homem, independente de todas as formas de sociedade, eterna necessidade natural de mediação do metabolismo entre homem e natureza e, portanto, da vida humana [O Capital I-I, p. 50; El Capital I-I, p. 53].

Os valores de uso são o produto de

dois elementos, matéria fornecida pela natureza e trabalho. (...) o trabalho não é a única fonte dos valores de uso que produz, da riqueza material. Dela o trabalho é o pai, como diz William Petty, e a terra a mãe [O Capital I-I, pp. 50-1; El Capital I-I, p. 53].

Esta afirmação de que o trabalho não é a única fonte dos valores de uso e da riqueza material, que contrasta com sua condição de fonte exclusiva do valor, é reforçada um pouco adiante, quando Marx trata da influência do progresso técnico, do desenvolvi- 
mento da produtividade (ou força produtiva, como ele mais freqüentemente prefere dizer). Ao retomar com maior detalhe o conceito de tempo de trabalho socialmente necessário, ele assinala que o aumento da força produtiva do trabalho implica a produção de maior quantidade de valores de uso em determinada fração de tempo, mas não a produção de maior quantidade de valor. Isto porque a

[f]orça produtiva é sempre, naturalmente, força produtiva de trabalho útil concreto, e determina, de fato, apenas o grau de eficácia de uma atividade produtiva adequada a um fim, num espaço de tempo dado. O trabalho útil torna-se, portanto, uma fonte mais rica ou mais pobre de produtos, em proporção direta ao aumento ou à queda de sua força produtiva. Ao contrário, uma mudança da força produtiva não afeta, em si e para si, de modo algum o trabalho representado no valor. Como a força produtiva pertence à forma concreta útil de trabalho, já não pode esta, naturalmente, afetar o trabalho, tão logo faça-se abstração da sua forma concreta útil [O Capital I-I, p. 53; El Capital I-I, pp. 56-7].

Ou seja, a produção física diverge da produção de valor; a produção de riqueza material se separa da produção da riqueza em valor (abstrata). Voltaremos a esta questão, que é um dos desdobramentos mais importantes da dupla natureza do trabalho na economia capitalista, no Capítulo 3 (subseção 3.2.4) e no Capítulo 5.

Outra questão relativa à quantificação do valor deve ser mencionada. Para medir o valor pelo tempo de trabalho não basta considerar o tempo socialmente necessário, é necessário que, além disto, o trabalho seja simples, "dispêndio de força de trabalho simples que em média toda pessoa comum, sem desenvolvimento especial, possui em seu organismo físico"; o trabalho mais complexo "vale apenas como trabalho simples potenciado ou, antes, multiplicado, de maneira que um pequeno quantum de trabalho complexo é igual a um grande quantum de trabalho simples" [O Capital I-I, p. 51; El Capital I-I, pp. 54-5]. Este tema será discutido na subseção 3.3.4 do Capítulo 3.

\subsection{2 - Forma do valor e dinheiro}

Depois da análise do duplo caráter da mercadoria e do trabalho que a produz, segue-se o estudo da gênese do dinheiro, feito na terceira parte do Capítulo I do Livro I de $O$ Capital ("A forma de valor ou o valor de troca"). Partindo da existência de mercadorias como unidades de valor de uso e valor, e portanto também do duplo caráter do trabalho 
produtor de mercadorias, Marx analisa como o valor se expressa na relação entre duas ou mais mercadorias, até chegar ao dinheiro ${ }^{7}$. Parte da constatação de que a forma mercadoria se desdobra em forma natural e forma de valor; e de que o valor deve se expressar em algo distinto do corpo da própria mercadoria (que constitui seu valor de uso), e além disto distinto dele próprio, uma vez que não pode fazê-lo diretamente como quantidade de trabalho abstrato: este não é visível, não tem existência material e, além disso, sua objetividade é puramente social, só se manifesta na relação entre duas ou mais mercadorias:

As mercadorias vêm ao mundo sob a forma de valores de uso ou de corpos de mercadorias, como ferro, linho, trigo etc. Essa é a sua forma natural com que estamos habituados. Elas só são mercadorias, entretanto, devido à sua duplicidade, objetos de uso e simultaneamente portadores de valor. Elas aparecem, por isso, como mercadoria ou possuem a forma de mercadoria apenas na medida em que possuem forma dupla, forma natural e forma de valor.

A objetividade do valor das mercadorias diferencia-se de Mrs. Quickly ${ }^{8}$, pois não se sabe por onde apanhá-la. Em direta oposição à palpável e rude objetividade dos corpos das mercadorias, não se encerra nenhum átomo de matéria natural na objetividade de seu valor. Podemos virar e revirar uma mercadoria, como queiramos, como coisa de valor ela permanece imperceptível. Recordemo-nos, entretanto, que as mercadorias apenas possuem objetividade de valor na medida em que elas sejam expressões da mesma unidade social de trabalho humano, pois sua objetividade de valor é puramente social e, então, é evidente que ela pode aparecer apenas numa relação social de mercadoria para mercadoria [O Capital II, p. 53-4; El Capital: I-I, p. 58].

Sendo o valor a cristalização do trabalho abstrato, a tarefa de expressá-lo deve ser entendida como a de expressar o trabalho abstrato, expressar o caráter específico do trabalho gerador de valor. Mas como o trabalho só é valor em estado cristalizado, e o valor

\footnotetext{
${ }^{7}$ A importância que ele dá a este desenvolvimento fica clara: “Aqui cabe, no entanto, realizar o que não foi jamais tentado pela economia burguesa, isto é, comprovar a gênese dessa forma dinheiro, ou seja, acompanhar o desenvolvimento da expressão de valor contida na relação de valor das mercadorias, de sua forma mais simples e sem brilho até a ofuscante forma dinheiro. Com isso desaparece o enigma do dinheiro" $[O$ Capital I-I, p. 54; El Capital I-I, p. 59].

${ }^{8}$ Personagem de Shakespeare. Na edição brasileira consta o nome germânico — Wittib Hurtig. Parece preferível, evidentemente, citar o nome em inglês, conforme faz a edição de Siglo Veintiuno Editores.
} 
das diversas mercadorias consiste naquilo que elas têm em comum, o valor e o trabalho abstrato devem expressar-se através da equivalência de espécies diferentes de mercadorias:

Somente a expressão de equivalência de diferentes espécies de mercadorias revela o caráter específico do trabalho gerador de valor, ao reduzir, de fato, os diversos trabalhos contidos nas mercadorias diferentes a algo comum neles, ao trabalho humano em geral.

Não basta, porém, expressar o caráter específico do trabalho em que consiste o valor do linho. A força de trabalho do homem em estado líquido ou trabalho humano cria valor, porém não é valor. Ele torna-se valor em estado cristalizado, em forma concreta. Para expressar o valor do linho como gelatina de trabalho humano, ele deve ser expresso como uma "objetividade" concretamente diferente do linho mesmo e simultaneamente comum ao linho e a outra mercadoria. A tarefa já está resolvida [O Capital I-I, p. 56; El Capital: I-I, pp. $62-3]$.

Podemos acrescentar uma razão adicional para que o valor só possa se expressar, por assim dizer, com um desvio. Marx já tocou brevemente nesta questão, mas só a explicitará mais adiante, ao justificar porque o dinheiro não pode ser substituído por "certificados de trabalho". O dinheiro deve expressar a quantidade de trabalho abstrato, e esta quantidade não corresponde exatamente à quantidade de trabalho concreto realizada, não se mede diretamente pelas horas efetivamente trabalhadas; exige processos de igualação social e de reconhecimento social $^{9}$ (já que é preciso determinar qual é a quantidade de trabalho socialmente necessário, bem como fazer a redução do trabalho complexo - qualificado - a trabalho simples ${ }^{10}$, e ainda verificar em que medida o trabalho despendido atende necessidades sociais).

O valor deve se expressar, portanto, como relação entre mercadorias. Tomemos inicialmente a relação entre duas mercadorias. Nela existem dois pólos: a forma relativa e a forma equivalente de valor. Uma mercadoria está na forma relativa quando expressa seu valor em outra; está na forma equivalente quando empresta seu corpo (seu valor de uso) para que outra mercadoria expresse nele seu valor. Na forma equivalente, uma vez que o corpo da mercadoria B é usado para expressar o valor da mercadoria A, "o valor de uso

\footnotetext{
${ }^{9}$ Ver adiante a subseção 1.3.1 deste Capítulo, e o Capítulo 3, subseção 3.3.6.

${ }^{10}$ A segunda parte do Capítulo I de O Capital trata brevemente da distinção entre trabalho simples e trabalho complexo, questão que deixamos para o Capítulo 3, subseção 3.3.4.
} 
torna-se forma de manifestação de seu contrário, do valor" [O Capital I-I: 59]. Ao mesmo tempo, "o trabalho concreto" se converte "na forma de manifestação de seu contrário, trabalho humano abstrato", e o trabalho privado (o trabalho do produtor da mercadoria B, que está na forma de equivalente) se converte "na forma de seu contrário, trabalho em forma diretamente social" [O Capital I-I: 61].

A análise desta relação permite então concluir que:

A antítese interna entre valor de uso e valor, oculta na mercadoria, é, portanto, representada por meio de uma antítese externa, isto é, por meio da relação entre duas mercadorias, na qual uma delas, cujo valor deve ser expresso, funciona diretamente apenas como valor de uso; a outra, ao contrário, na qual o valor é expresso, vale diretamente apenas como valor de troca. [O Capital I-I, p. 63; El Capital, I-I, p. 75].

Vê-se claramente, nesta relação entre duas mercadorias, a origem do dinheiro. " $A$ tarefa já está resolvida".

A relação entre forma relativa e forma de equivalente se desenvolve partindo da forma simples (que ele chama também de forma I), passando pela forma total ou desdobrada (a forma II), e chegando à forma geral de valor (a forma III). Na primeira, uma mercadoria A qualquer está na forma relativa, e expressa seu valor numa outra mercadoria $\mathrm{B}$ qualquer, que está na forma equivalente. Na segunda, uma mercadoria A qualquer está na forma relativa, e expressa seu valor em todas as outras mercadorias, que ficam portanto na forma equivalente - nesse caso, trata-se então da forma relativa desdobrada e da forma equivalente particular. Na terceira, que é a segunda forma invertida, uma única mercadoria fica na forma equivalente - torna-se portanto o equivalente geral — e todas as outras mercadorias, na forma relativa geral, expressam nela seu valor. Forma relativa e forma equivalente se desenvolvem simultaneamente.

Na versão do Capítulo I da primeira edição de $O$ Capital $^{11}$, Marx resume de maneira sugestiva a progressão das três formas, pondo em destaque o desenvolvimento da sua capacidade de expressar o valor. Inicialmente, compara a forma I e a forma II $^{12}$.

\footnotetext{
${ }^{11}$ Reproduzida como apêndice na edição de El Capital da Siglo Veintiuno Editores, volume I-III, pp. 9691016.
} 
Na expressão: 20 varas de linho $=1$ casaco, o casaco contava como forma de objetivação do trabalho objetivado no linho. Desta maneira, o trabalho contido no linho se equiparava ao contido no casaco, ficando determinado, por conseguinte, como trabalho humano indiferenciado. Entretanto, esta determinação não se manifesta de maneira expressa. Diretamente, a primeira forma se limita a equiparar o trabalho contido no linho ao trabalho de alfaiate. O mesmo não acontece no caso da segunda forma. Na série infinita, sempre prolongável, de suas expressões relativas de valor, o linho se relaciona com todos os corpos possíveis de mercadorias como meras formas de manifestação do trabalho contido no mesmo. É aqui, pois, onde pela primeira vez o valor do linho se representa verdadeiramente como valor, isto é, cristal de trabalho humano em geral [El Capital I-III, p. 996].

A forma III representa mais um passo, e decisivo, para a expressão do valor. O casaco, o café, o chá, o ferro, o trigo, etc., representam seu valor no corpo do linho, que ocupa a posição de equivalente geral.

Agora, a mesma forma representa o casaco como valor também frente a todas as demais mercadorias e é, por conseguinte, a forma de valor válida geralmente do casaco. Não apenas o casaco, mas também o café, o ferro, o trigo, em suma, todas as demais mercadorias expressam agora seu valor no material linho. Todas se representam assim uma na outra como a mesma concretização material de trabalho humano. Diferem unicamente no quantitativo, pelo que 1 casaco, $u$ café, $x$ ferro, etc., isto é, quantidades diferentes destas coisas diferentes, $=20$ varas de linho, igual à mesma quantidade de trabalho humano objetivado. Enquanto valores de troca, todas as mercadorias se distinguem - por sua comum expressão de valor no material linho - de seus próprios valores de uso, e por sua vez se relacionam entre si como magnitudes de valor, se equiparam qualitativamente e se igualam quantitativamente. Tão somente nesta expressão relativa unitária de valor todas as mercadorias se manifestam reciprocamente como valores e o valor das mesmas, por conseguinte, adota pela primeira vez sua forma de manifestação adequada como valor de troca [El Capital IIII, p. 997].

O equivalente geral é a mercadoria em que todas as outras - que se colocam na forma relativa geral de valor — se reconhecem, e pela qual são imediatamente intercambiáveis; é, portanto, a forma social por excelência do valor. O trabalho que produz o equiva-

\footnotetext{
${ }^{12}$ Esse desenvolvimento corresponde, na versão final do Capítulo I, às pp. 66-7 da edição Nova Cultural, e às pp. 80-1 da edição Siglo Veintiuno.
} 
lente geral é reconhecido de imediato como trabalho social, e torna-se uma representação positiva das características comuns a todos os trabalhos humanos.

Assim, o trabalho objetivado no valor das mercadorias não se representa apenas de um modo negativo, como trabalho em que todas as formas concretas e propriedades úteis dos trabalhos reais são abstraídas. Sua própria natureza positiva é expressamente ressaltada. Ele é a redução de todos os trabalhos reais à sua característica comum de trabalho humano, ao dispêndio de força de trabalho do homem.

A forma geral de valor ${ }^{13}$, que representa os produtos de trabalho como meras gelatinas de trabalho humano indiferenciado, mostra por meio de sua própria estrutura que é a expressão social do mundo das mercadorias. Assim, ela evidencia que no interior desse mundo o caráter humano geral do trabalho constitui seu caráter especificamente social ${ }^{14}$ [O Capital I-I, p. 67; El Capital: I-I, p. 82].

Finalmente, a progressão da forma III para a forma IV (o dinheiro) é relativamente mais simples. A forma equivalente geral implica "naturalmente a exclusão social de uma classe determinada de mercadoria com respeito a todas as demais mercadorias". Para passar à forma dinheiro,

[t]rata-se unicamente de que esta exclusão ganhe consistência objetivamente social e vigência geral, e portanto não recaia de maneira alternada em mercadorias diferentes, nem tenha um campo de ação meramente local, restringido apenas a esferas particulares do mundo das mercadorias. A dificuldade que apresenta o conceito da forma de dinheiro se reduz a compreender a forma de equivalente geral, e conseqüentemente a forma geral de valor em geral, a forma III. Porém a forma III se resolve por sua vez na II; e o elemento constitutivo da forma II é a forma I [El Capital I-III, p. 1042] ${ }^{15}$.

A forma de equivalente deve pois se desenvolver até chegar a uma forma que seja geral, aceita como expressão do valor de todas as mercadorias, e que tenha reconhecimento social - a forma de dinheiro. A antítese interna a cada mercadoria entre valor de uso e valor se desdobra até chegar à antítese externa entre mercadoria e dinheiro.

\footnotetext{
${ }^{13}$ A tradução da Nova Cultural foi ligeiramente alterada. Estava “forma valor geral”, o que é menos claro.

${ }^{14} \mathrm{O}$ “caráter especificamente social” do trabalho é analisado adiante, na próxima subseção.

${ }^{15}$ Esta citação é do anexo sobre A Forma de Valor do Capítulo I na primeira edição do Livro I de O Capital, publicado como apêndice à edição de Siglo Veintiuno Editores.
} 
$\mathrm{Na}$ análise lógica da forma de valor que Marx realiza no Capítulo I do Livro I de $O$ Capital, são as limitações da forma simples que fazem a antítese valor de uso $x$ valor se desenvolver até a separação entre mercadoria e dinheiro; a progressão forma simples do valor $\rightarrow$ forma total $\rightarrow$ forma geral $\rightarrow$ dinheiro reflete a busca por parte do valor de uma forma adequada de expressão. O dinheiro, como vimos, já se anuncia na relação de troca entre duas mercadorias, na forma simples do valor — pois já neste caso uma mercadoria, colocada na forma relativa de valor, faz da forma natural de outra mercadoria, colocada na forma equivalente, sua forma de valor.

É importante salientar qual é o conceito de dinheiro a que se chegou. Em toda a análise da forma do valor, o que se explicita é que a substância social que constitui o valor encontra uma forma adequada de expressão no dinheiro. Assim, o dinheiro é:

“a encarnação visível, a crisálida social geral de todo trabalho humano" [O Capital I-I, p. 67; El Capital I-I, p. 82]; “(...) forma adequada de manifestação do valor ou materialização do trabalho humano abstrato" [O Capital I-I, p. 83; El Capital I-I, p. 109]; “...equivalente geral, corpo geral do valor, concretização material geral do trabalho humano abstrato" [El Capital I-III, p. $998^{16}$ ].

O dinheiro é a mercadoria geral:

Sendo todas as mercadorias meros equivalentes particulares do dinheiro e o dinheiro seu equivalente geral, elas se relacionam como mercadorias particulares em relação ao dinheiro, como a mercadoria geral [O Capital I-I, p. 83; El Capital I-I, p. 110].

E para concluir estas citações com fórmulas especialmente sugestivas:

(...) o ouro é o modo de ser material da riqueza abstrata. (...) Por sua forma, é a encarnação imediata do trabalho geral... [Para a Crítica da Economia Política, p. 92].

Uma última observação é, no entanto, necessária. O dinheiro é a forma adequada e necessária da representação do valor das mercadorias; no entanto, expressa o valor de modo imperfeito: seu próprio valor é variável. Como Marx explicitou na análise da determinação quantitativa da forma relativa do valor, ainda no quadro da forma simples - mas tudo o que é dito vale igualmente quando o dinheiro está na forma equivalente.

\footnotetext{
${ }^{16}$ Texto do Capítulo I na $1^{\mathrm{a}}$ edição de $O$ Capital.
} 
As mudanças reais na grandeza de valor não se refletem, nem clara nem completamente, em sua expressão relativa ou na grandeza do valor relativo. $O$ valor relativo de uma mercadoria pode mudar, apesar de seu valor permanecer constante. Seu valor relativo pode permanecer constante, apesar de mudar seu valor e, finalmente, não necessitam, de nenhuma forma, coincidir as mudanças simultâneas em sua grandeza de valor e na expressão relativa desta grandeza [O Capital I-I, p. 59; El Capital I-I, p. 67].

\subsection{3 - Fetichismo da mercadoria e especificidade histórica da econo-}

\section{mia mercantil}

A última parte do Capítulo I de O Capital chama-se "o caráter fetichista da mercadoria e seu segredo". Como já foi observado ${ }^{17}$, o fetichismo da mercadoria, é um tema decisivo para todo o projeto de crítica da economia política; perpassa todo O Capital $^{18}$.

As mercadorias têm um caráter misterioso que provém de sua forma mesma de mercadoria. O fetichismo da mercadoria consiste na transformação de características das relações sociais entre os homens em propriedades das mercadorias, isto é, das coisas:

O misterioso da forma mercadoria consiste, portanto, simplesmente no fato de que ela reflete aos homens as características sociais do seu próprio trabalho como características objetivas dos próprios produtos de trabalho, como propriedades naturais sociais dessas coisas e, por isso, também reflete a relação social dos produtores com o trabalho total como uma relação social existente fora deles, entre objetos. Por meio deste qüiproquó os produtos do trabalho se tornam mercadorias, coisas sensíveis e supra-sensíveis ou sociais ${ }^{19}$ [O Capital I-I, p. 71; El Capital I-I, p. 88].

\footnotetext{
${ }^{17}$ Isaak Rubin diz que "o fundamento dialético completo da teoria de Marx sobre o valor só pode ser exposto sobre a base de sua teoria do fetichismo da mercadoria, que analisa a estrutura geral da economia mercantil" [Rubin 1980, p. 76; a tradução foi modificada com base na edição em espanhol, Rubin 1974, p. 113].

${ }^{18}$ Exemplos dessa onipresença do tema do fetichismo são a análise que Marx faz no Capítulo I do Livro II, quando retoma a questão da circulação do capital, e a discussão da última seção do Livro III, "Os Rendimentos e suas Fontes".

${ }^{19}$ Como a palavra metafisicas tem conotações muito especiais, e não foi usada no original alemão, modificamos ligeiramente a tradução brasileira. A edição da Nova Cultural diz "coisas físicas metafísicas ou sociais". No entanto, o original alemão é "sinnliche übersinnliche oder gesellchaftliche Dinge" [Das Kapital I, p. 86], que corresponde a "coisas sensíveis supra-sensíveis ou sociais". A tradução francesa de Joseph Roy, revista
} 
(...) $[\mathrm{P}]$ ara encontrar uma analogia temos de nos deslocar à região nebulosa do mundo da religião.Aqui, os produtos do cérebro humano parecem dotados de vida própria, figuras autônomas, que mantêm relações entre si e com os homens. Assim, no mundo das mercadorias, acontece com os produtos da mão humana. Isso eu chamo o fetichismo que adere aos produtos do trabalho, tão logo são produzidos como mercadorias, e que, por isso, é inseparável da produção de mercadorias.

Este caráter fetichista do mundo das mercadorias provém, como a análise precedente já demonstrou, do caráter social peculiar do trabalho que produz mercadorias [O Capital I-I, p. 71; El Capital I-I, p. 89].

$\mathrm{O}$ fetichismo da mercadoria tem origem portanto no fato de que a forma mercadoria reflete para os homens as características sociais do seu próprio trabalho como características objetivas dos próprios produtos do trabalho. Trata-se, portanto, do caráter social peculiar do trabalho que produz mercadorias — ou seja, do seu duplo caráter. Marx já havia mencionado, como vimos, o desenvolvimento de uma divisão social do trabalho - portanto, de um caráter social do trabalho, vinculado às características do trabalho concreto, produtor de valores de uso, de coisas que satisfazem necessidades sociais. Além disso, na discussão sobre a forma do valor, falou de um caráter especificamente social do trabalho produtor de mercadorias. Cabe agora destacar e explicar esse desdobramento, a duplicação do caráter social do trabalho.

Na produção mercantil, o caráter social do trabalho concreto torna-se indireto, pois este só atua como trabalho social por meio de relações de troca. Por isso, o trabalho concreto torna-se privado e indiretamente social; as relações sociais entre as pessoas são reificadas, mediadas pelos produtos do seu trabalho (ou o que é o mesmo: o caráter social do trabalho é objetivado, transformado num atributo do produto do trabalho):

por Marx, diz: “choses qui tombent et ne tombent pas sous les sens, ou choses sociales” [Le Capital I, p. 606], que corresponde a "coisas que caem e não caem sob os sentidos, ou coisas sociais", equivalente ao original alemão. Nesta expressão, a edição Siglo Veintiuno também não é feliz: diz "coisas sensorialmente supra-sensíveis ou sociais", o que tornaria as mercadorias apenas "supra-sensíveis", quando parece claro que Marx pretendia chamar a atenção para que as mercadorias são tanto sensíveis quanto supra-sensíveis ou sociais. A edição inglesa [Capital I, Penguin Books, p. 165] diz corretamente "sensuous things which are at the same time supra-sensible or social". 
(...) Como os produtores somente entram em contato social mediante a troca de seus produtos do trabalho, as características especificamente sociais de seus trabalhos privados só aparecem dentro desta troca. Em outras palavras, os trabalhos privados só atuam, de fato, como membros do trabalho social total por meio das relações de troca que se estabelecem entre os produtos do trabalho e, por meio dos mesmos, entre os produtores. Por isso, aos últimos aparecem as relações sociais entre seus trabalhos privados como o que são, isto é, não como relações diretamente sociais entre pessoas em seus próprios trabalhos, senão como relações reificadas entre as pessoas e relações sociais entre as coisas [O Capital I-I, p. 71; El Capital I-I, p. 89].

O duplo caráter social do trabalho resulta de uma duplicação dos trabalhos privados dos produtores: estes satisfazem determinada necessidade social como trabalhos úteis (nesta qualidade, são trabalhos indiretamente sociais, como já vimos); e satisfazem às necessidades de seus próprios produtores como trabalhos permutáveis por qualquer outra espécie de trabalho privado, assumem a forma de socialidade própria à economia mercantil (nesta qualidade, podemos dizer que são diretamente sociais $^{20}$ ):

Somente dentro da sua troca, os produtos recebem uma objetividade de valor socialmente igual, separada de sua objetividade de uso, fisicamente diferenciada. Essa cisão do produto de trabalho em coisa útil e coisa de valor realiza-se apenas na prática, tão logo a troca tenha adquirido extensão e importância suficientes para que se produzam coisas úteis para serem trocadas, de modo que o caráter de valor das coisas já seja considerado ao serem produzidas. A partir deste momento, os trabalhos privados dos produtores adquirem realmente duplo caráter social [grifo JM]. Por um lado, eles têm de satisfazer determinada necessidade social, como trabalhos determinados úteis, e assim serem participantes do trabalho total, do sistema naturalmente desenvolvido da divisão social do trabalho. Por outro lado, só satisfazem às múltiplas necessidades de seus próprios produtores, na medida em que

\footnotetext{
${ }^{20}$ Algumas páginas adiante, contrapondo o caráter social do trabalho na economia mercantil e na "sombria Idade Média européia”, Marx diz: “A forma natural do trabalho, sua particularidade, e não, como na base da produção de mercadorias, sua generalidade, é aqui sua forma diretamente social” [O Capital I-I, p. 74; El Capital I-I, p. 94]. Assim, "na base da produção de mercadorias" a generalidade do trabalho é sua "forma diretamente social". Moishe Postone chama enfaticamente a atenção para que o trabalho no capitalismo é diretamente social enquanto trabalho abstrato [Postone 1993, pp. 46-9]; voltaremos à interpretação de Postone desta questão logo adiante, na subseção 1.4.3.
} 
cada trabalho útil particular é permutável por toda outra espécie de trabalho privado, portanto lhe equivale [O Capital I-I, pp. 71-2; El Capital I-I, pp. 89-90].

É o desenvolvimento desta segunda forma de socialidade — isto é, a permutabilidade geral dos trabalhos —, ao lado da "socialidade natural" da divisão social do trabalho (da utilidade social), que torna o trabalho, além de concreto, também abstrato, e que constitui os valores das mercadorias como sua objetivação:

A igualdade de trabalhos toto coelo diferentes só pode consistir numa abstração de sua verdadeira desigualdade, na redução ao caráter comum que eles possuem como dispêndio de força do trabalho do homem, como trabalho humano abstrato. O cérebro dos produtores privados apenas reflete esse duplo caráter social de seus trabalhos privados sob aquelas formas que aparecem na circulação prática, na troca de produtos - o caráter socialmente útil de seus trabalhos privados, portanto, sob aquela forma que o produto do trabalho tem de ser útil, isto é, útil aos outros - o caráter social da igualdade dos trabalhos de diferentes espécies sob a forma do caráter de valor comum a essas coisas materiais diferentes, os produtos do trabalho.

Portanto, os homens relacionam entre si seus produtos do trabalho como valores não porque considerem essas coisas como meros envoltórios materiais de trabalho humano da mesma espécie. Ao contrário. Ao equiparar seus produtos de diferentes espécies na troca, como valores, equiparam seus diferentes trabalhos como trabalho humano. Não o sabem, mas of fazem [O Capital I-I, p. 72; El Capital I-I, p. 90].

O texto de Para a Crítica da Economia Política destaca o tipo específico da socialidade do trabalho produtor de mercadorias: o trabalho é social enquanto geral:

As condições do trabalho que põe valor de troca ${ }^{21}$, tais como resultam da análise do valor de troca, são determinações sociais do trabalho, ou determinações de trabalho social, mas não pura e simplesmente social, mas de um modo particular: é um tipo específico de socialidade. A simplicidade indiferenciada do trabalho é, em primeiro lugar, igualdade dos trabalhos de diferentes indivíduos, relacionamento recíproco de seus trabalhos como iguais, e isso mediante uma redução de fato de todos os trabalhos a trabalho de igual tipo. O traba-

\footnotetext{
${ }^{21}$ Aqui seria mais correto, de acordo com a terminologia definitiva de Marx, falar de valor, e não de valor de troca, já que a referência é ao conteúdo, e não à forma de expressão. Marx só passou a adotar de modo rigoroso a diferenciação entre os dois termos a partir da $2^{\mathrm{a}}$ edição do Livro I de $O$ Capital. Ver, a este respeito, o artigo esclarecedor de Gary Young [1976].
} 
lho de qualquer indivíduo, enquanto se apresente em valores de troca, possui esse caráter social de igualdade, e só se apresenta no valor de troca enquanto se relacione como igual com o trabalho de todos os outros indivíduos. Além disso, no valor de troca o tempo de trabalho de um só indivíduo aparece diretamente como tempo de trabalho geral e esse caráter geral do trabalho individualizado aparece como caráter social dele. O tempo de trabalho apresentado no valor de troca é tempo de trabalho do indivíduo, mas de um indivíduo que não se distingue de outro nem de todos os demais indivíduos enquanto realizem trabalho igual; daí ser o tempo de trabalho requerido por um deles para a produção de uma determinada mercadoria o tempo de trabalho necessário que qualquer outro empregaria para a produção da mesma mercadoria. É o tempo de trabalho do indivíduo, é seu tempo de trabalho, mas somente como tempo de trabalho comum a todos, que, por isso mesmo, é indiferente de qual indivíduo seja tempo de trabalho. Como tempo de trabalho geral, ele se apresenta em um produto geral, um equivalente geral, uma determinada quantia de tempo de trabalho objetivada que é indiferente à forma determinada do valor de uso, na qual aparece como produto imediato de um indivíduo, e é traduzível à vontade em qualquer outra forma de valor de uso, na qual se apresenta como o produto de qualquer outro. Só enquanto grandeza geral é grandeza social. Para que o trabalho do indivíduo possa resultar em valor de troca, deve resultar em um equivalente geral, isto é na apresentação do tempo de trabalho do indivíduo como tempo de trabalho geral, ou na apresentação do tempo de trabalho geral como tempo de trabalho do indivíduo. É como se os indivíduos diversos tivessem juntado seu tempo de trabalho e tivessem apresentado as quantias diversas do tempo de trabalho de que dispõem coletivamente em valores de uso diversos. O tempo de trabalho do indivíduo é, de fato, o tempo de trabalho que a sociedade necessita para a apresentação de um valor de uso determinado, ou seja, para a satisfação de uma necessidade determinada. Trata-se porém, aqui, apenas da forma específica pela qual o trabalho recebe um caráter social [Para a Crítica da Economia Política, p. 34-5].

Outra passagem da mesma obra também deixa claro que o trabalho se torna social enquanto geral, enquanto assume a forma da generalidade abstrata:

O trabalho que se apresenta no valor de troca é pressuposto como trabalho do indivíduo particularizado e se torna social assumindo a forma do seu oposto direto: a forma da generalidade abstrata [Para a Crítica da Economia Política, p. 35].

Assim, ao trabalhar para a troca, os produtores dão origem a um segundo tipo de socialidade do trabalho: o trabalho assume a forma da generalidade abstrata; torna-se abstrato; neste sentido, é diretamente social 
Os produtores, na sua prática social, relacionam seus produtos como valores, e é através deles que se relacionam uns com os outros. O trabalho - objetivado - torna-se uma forma de mediação social ${ }^{22}$. Assim, as características sociais da atividade produtiva aparecerem como propriedades naturais sociais das mercadorias, se reificam, e se tornam um fetiche. Neste processo de reificação de relações sociais a substância do valor é constituída. A substância que constitui o valor se forma pela reificação de relações sociais. É por isso que ela é uma substância peculiar, especialíssima, uma substância social, na qual não é possível descobrir nenhum átomo de matéria física.

No restante da discussão sobre o fetichismo da mercadoria, Marx aponta que as características da economia mercanti1 ${ }^{23}$ estudadas não existem em outras formas de organização econômica. O que estas outras formas econômicas não têm é precisamente a duplicação das categorias econômicas: têm trabalho concreto mas não trabalho abstrato, valor de uso mas não valor (e portanto não têm mercadoria), riqueza material mas não riqueza abstrata; o trabalho assume aí um caráter social (se há divisão social do trabalho, o que exclui, naturalmente, o caso de Robinson), mas não se trata do caráter social próprio à economia mercantil; portanto não há fetichismo. A economia mercantil é historicamente específica.

\subsection{4 - Desenvolvimento das trocas e da produção de mercadorias}

No Capítulo II do Livro I de O Capital, Marx retoma vários dos temas do Capítulo I. Para os objetivos deste trabalho, é importante ressaltar um deles: como o desenvolvimento e a generalização das trocas impulsionam dois processos estreitamente vinculados (na verdade, não se trata propriamente de dois processos, mas de dois aspectos de um mesmo processo social):

a) A alteração da natureza dos produtos do trabalho que, adquirindo uma segunda natureza - a de valores —, tornam-se mercadorias. Ao mesmo tempo, é duplicado o caráter do trabalho: ao lado do trabalho concreto, constitui-se o trabalho abstrato, substância do valor. (Sendo o trabalho

\footnotetext{
${ }^{22}$ Moishe Postone destaca esta característica específica ao modo capitalista de produção: o trabalho torna-se uma forma de mediação social, substituindo relações sociais abertas [Postone 1993, pp. 148-57].

${ }^{23}$ Como diz Ruy Fausto, o que é analisado aqui é de fato a produção capitalista enquanto produção de mercadorias [Fausto 1983c, p. 122, nota 50]. Voltaremos a esta questão no Capítulo 2, subseção 2.2.2.
} 
abstrato a substância do valor, isto é, sendo o valor trabalho abstrato objetivado, esta duplicação é feita conjuntamente com a transformação dos produtos do trabalho em mercadoria; duplicação dos produtos do trabalho - sua transformação em mercadorias - e duplicação do trabalho em abstrato e concreto são um e o mesmo processo.)

b) A formação do dinheiro.

De que maneira os produtos do trabalho tornam-se mercadorias? Esta transformação não é uma coisa simples, e não pode ser apenas suposta, tem de ser também explicada. Marx já abordou esta questão no texto sobre o fetichismo da mercadoria, quando a analisou juntamente com a questão da duplicação do caráter social do trabalho produtor de mercadorias. No Capítulo II ele a retoma de modo mais amplo.

Inicialmente, a constituição dos diversos trabalhos individuais e privados em tempo de trabalho geral, e a transformação dos produtos do trabalho em mercadorias, parecem ser inviabilizadas por um círculo vicioso:

Todas as mercadorias são não-valores de uso para seus possuidores e valores de uso para seus não-possuidores. Elas precisam, portanto, universalmente mudar de donos. Mas esta mudança de donos constitui sua troca e essa troca as refere como valores entre si e as realiza como valores. As mercadorias, pois, têm primeiro que realizar-se como valores, antes de poderem realizar-se como valores de uso.

Por outro lado, as mercadorias têm de comprovar-se como valores de uso, antes de poderem realizar-se como valores. Pois o trabalho humano, despendido em sua produção, conta somente na medida em que seja despendido de forma útil para outros. Se o trabalho é útil para outros, se, portanto, seu trabalho satisfaz a necessidades alheias, somente sua troca pode demonstrar.

Todo possuidor de mercadorias só quer alienar sua mercadoria por outra mercadoria cujo valor de uso satisfaça à sua própria necessidade. Nessa medida, a troca é para ele apenas um processo individual. Por outro lado, ele quer realizar sua mercadoria enquanto valor, e portanto convertê-la em qualquer outra mercadoria que o agrade e valha o mesmo, sendo indiferente que sua própria mercadoria tenha ou não valor de uso para o possuidor da outra. Nessa medida, a troca é para ele um processo social geral. Mas o mesmo processo não pode ser simultaneamente para todos os possuidores de mercadorias apenas individual e, ao mesmo tempo, apenas social geral. 
Vista a coisa mais de perto, percebe-se que para todo possuidor de mercadoria toda mercadoria alheia se lhe apresenta como equivalente particular de sua mercadoria, e esta, portanto, como equivalente geral de todas as outras mercadorias. Mas como todos os possuidores de mercadorias fazem o mesmo, nenhuma mercadoria é equivalente geral e por isso as mercadorias não possuem também nenhuma forma valor geral relativa, na qual elas possam equiparar-se como valores e comparar-se como grandezas de valor. Portanto, elas não se defrontam, de modo algum, como mercadorias, mas apenas como produtos ou valores de uso [O Capital I-I: 80; El Capital: I-I: 105].

Esse impasse só pode ser resolvido pela ação dos produtores de mercadorias:

Em sua perplexidade, pensam os nossos possuidores de mercadorias como Fausto. No começo era a ação. Eles já agiram, portanto, antes de terem pensado. As leis da natureza das mercadorias atuam através do instinto natural dos seus possuidores. Eles somente podem referir suas mercadorias, umas às outras, como valores, e por isso apenas como mercadorias, ao referi-las, antiteticamente, a outra mercadoria como equivalente geral. É o que resultou da análise da mercadoria. Mas apenas a ação social pode fazer de uma mercadoria equivalente geral. A ação social de todas as outras mercadorias, portanto, exclui determinada mercadoria para nela representar universalmente seus valores. A forma natural dessa mercadoria vem a ser assim a forma equivalente socialmente válida. Ser equivalente geral passa, por meio do processo social, a ser função especificamente social da mercadoria excluida. Assim ela torna-se — dinheiro [O Capital I-I: 80-1; El Capital I-I: 105-6].

O processo de desenvolvimento das trocas, portanto, procede simultaneamente à transformação dos produtos do trabalho em mercadorias, através da sua duplicação em valor de uso e valor, e à transformação de uma mercadoria em dinheiro.

A ampliação e aprofundamentos históricos da troca desenvolvem a antítese entre valor de uso e valor latente na natureza da mercadoria. A necessidade de dar a esta antítese representação externa para a circulação leva a uma forma independente do valor da mercadoria e não se detém nem descansa até tê-la alcançado definitivamente por meio da duplicação da mercadoria em mercadoria em dinheiro. Na mesma medida, portanto, em que se dá a transformação do produto do trabalho em mercadoria, leva-se a cabo a transformação da mercadoria em dinheiro [O Capital I-I: 81; El Capital I-I: 106].

Identificamos essas transformações à medida que a troca deixa de ser uma coisa eventual e passa ser um processo social regular. Parte dos produtos começam a ser produzidos para a troca, com o que a proporção quantitativa em que se trocam começa a adquirir regularidade (de início é completamente fortuita) e a depender de sua produção; esses pro- 
dutos vão assumindo a forma de mercadoria, ou seja, tomando o duplo caráter de valor de uso e de valor.

A constante repetição da troca transforma-a em um processo social regular. Com o correr do tempo, torna-se necessário, portanto, que parte do produto do trabalho seja intencionalmente feita para a troca. A partir deste momento, consolida-se, por um lado, a separação entre a utilidade das coisas para as necessidades imediatas e sua utilidade para a troca. Seu valor de uso dissocia-se de seu valor de troca. Por outro lado, torna-se a relação quantitativa, em que se trocam, dependente de sua própria produção. O costume fixa-as como grandezas de valor [O Capital I-I: 82; El Capital I-I: 107-8].

A argumentação de que a transformação dos produtos do trabalho em mercadorias e a formação do dinheiro são concomitantes é completada por Marx com a consideração de que um passo decisivo é o artigo de troca adquirir uma forma de valor independente; essa forma (a forma relativa de valor) é desenvolvida a partir do fato de que para a generalização das trocas os possuidores de mercadorias devem compará-las com uma terceira mercadoria, sempre a mesma. Nasce o equivalente geral, e a partir daí o dinheiro; a forma relativa de valor das mercadorias torna-se forma relativa geral.

$\mathrm{Na}$ troca direta de produtos, cada mercadoria é diretamente meio de troca para seu possuidor, equivalente para seu não-possuidor, mas somente enquanto for valor de uso para ele. $\mathrm{O}$ artigo de troca não adquire ainda nenhuma forma de valor independente de seu próprio valor de uso ou da necessidade individual dos permutantes. A necessidade desta forma desenvolve-se com o crescente número e variedade das mercadorias que vão entrando no processo de troca. O problema surge simultaneamente com os meios para sua solução. Uma circulação em que possuidores de mercadorias trocam e comparam seus artigos com outros artigos diferentes jamais se realiza sem que diferentes mercadorias de diferentes possuidores de mercadorias em sua circulação sejam trocadas e comparadas como valores com uma terceira mercadoria, sempre a mesma. Tal terceira mercadoria, ao se tornar equivalente de outras mercadorias diferentes, recebe diretamente, ainda que em limites estreitos, a forma de equivalente geral ou social. Essa forma de equivalente geral surge e desaparece com o contato social momentâneo que lhe deu vida. É atribuída alternativa e transitoriamente a esta ou aquela mercadoria. Com o desenvolvimento da troca de mercadorias ela se fixa exclusivamente em espécies particulares de mercadorias ou se cristaliza na forma dinheiro [O Capital I-I: 82; El Capital I-I: 108].

Outra maneira de justificar por que a transformação dos produtos do trabalho em mercadorias (o que significa a duplicação valor de uso x valor, concomitantemente com a 
duplicação do caráter do trabalho) só pode ser feita ao mesmo tempo e no mesmo processo que a constituição social do dinheiro é chamar a atenção para as respectivas formas lógicas. Como vimos na seção 1.2.2, forma relativa geral do valor e equivalente geral são dois pólos da mesma relação. Produtos que assumem em geral a forma de mercadoria estão na forma relativa geral de valor, e o dinheiro é equivalente geral. O dinheiro só pode ser equivalente geral enquanto expressão da dimensão de valor das mercadorias que se encontram na forma relativa; as mercadorias só podem ter a dimensão de valor confrontando-se com o equivalente geral. Não pode existir dinheiro (no sentido pleno, de equivalente geral estabelecido socialmente) sem produção geral de mercadorias, nem produção geral de mercadorias sem dinheiro; do mesmo modo, a existência parcial do dinheiro e a existência de uma produção parcial de mercadorias se condicionam mutuamente. As duas coisas só podem andar juntas, e só podem portanto ser desenvolvidas conjuntamente.

Em resumo, o trabalho dos diversos produtores de mercadorias é trabalho concreto e privado; e na medida em que estes produtores participam de uma divisão social do trabalho, seu trabalho já é também (indiretamente) social enquanto trabalho concreto, útil satisfaz necessidades sociais. Por outro lado, como trabalho produtor de mercadorias, ele ganha também uma segunda natureza, uma segunda dimensão: é trabalho abstrato, e além disto social no sentido da socialidade específica da economia mercantil: é intercambiável por qualquer outro; desenvolve-se socialmente a indiferença com relação a seu conteúdo concreto. Embora esta duplicação se inicie quando as trocas começam a ganhar regularidade, só se completa quando elas se generalizam; isto passa pelo desdobramento das mercadorias em mercadorias e dinheiro.

A segunda natureza do trabalho, o trabalho abstrato, é uma substância social, a substância que constitui o valor. Sua formação exige, como vimos, a presença do dinheiro: é pela equiparação generalizada dos produtos do trabalho ao dinheiro que eles se tornam mercadorias, que se constitui o trabalho abstrato, que se desenvolve a socialidade específica do trabalho como intercambiabilidade geral dos trabalhos dos diversos produtores. $O$ processo de desenvolvimento das trocas transforma os produtos do trabalho em mercadorias, constitui progressivamente a substância social que é o trabalho abstrato, ao mesmo tempo constitui a forma de valor das mercadorias e impulsiona seu desenvolvimento até a forma de dinheiro. 


\section{3 - TEMPO DE TRABALHO, DINHEIRO E ACUMULAÇÃO}

\subsection{1 - Distinção entre tempo de trabalho, valor e preço}

O Capítulo III do Livro I de $O$ Capital trata das funções do dinheiro; representa uma parte fundamental da teoria monetária de Marx. Para o tema deste trabalho, contudo, apenas alguns aspectos interessam diretamente. Esta subseção aborda dois deles, estreitamente relacionados aliás: a possibilidade de divergência entre preço e valor, e a impossibilidade de o dinheiro representar diretamente o tempo de trabalho.

A partir da forma de dinheiro do valor define-se o preço (ou a forma preço) de uma mercadoria.

Dinheiro, como medida de valor, é a forma de manifestação necessária da medida do valor imanente das mercadorias: o tempo de trabalho.

A expressão do valor de uma mercadoria em ouro $-\mathrm{x}$ da mercadoria $\mathrm{A}=\mathrm{y}$ da mercadoria monetária - é sua forma de dinheiro ou seu preço [O Capital I-I, p. 86; El Capital I-I, pp. $115-6]$.

O preço é a denominação monetária do trabalho objetivado na mercadoria. (...) A grandeza de valor da mercadoria expressa, assim, uma relação necessária e imanente a seu processo de formação com o tempo de trabalho social. Com a transformação da grandeza do valor em preço, essa relação necessária aparece como a relação de troca de uma mercadoria com a mercadoria monetária, que existe fora dela [O Capital I-I, p. 91; El Capital I-I, pp. 124$5]$.

O preço é o valor expresso em dinheiro, é a medida da substância do valor de uma mercadoria - o trabalho abstrato - a partir da quantidade de trabalho representada pelo dinheiro, e não da quantidade de trabalho que ela própria custou. O preço, portanto, é um valor de troca específico, e é o que importa em uma economia monetária.

Mas, por outro lado, esta expressão do valor como preço permite a distinção entre preços e valores. Para mostrar como Marx trata desta questão, retomamos a citação anterior de forma mais ampla, destacando outro aspecto dela:

Mas se o preço, como expoente da grandeza de valor da mercadoria, é expoente de sua relação de troca com o dinheiro, não se segue, ao contrário, que o expoente de sua relação de troca com o dinheiro seja necessariamente o expoente de sua grandeza de valor. Suponhamos que trabalho socialmente necessário de igual grandeza represente-se em um quarter de 
trigo e em 2 libras esterlinas (...). As 2 libras esterlinas são a expressão monetária da grandeza de valor do quarter de trigo ou seu preço. Se as circunstâncias permitirem sua cotação a 3 libras esterlinas ou forçarem sua cotação a 1 libra esterlina, então, como expressão da grandeza de valor do trigo, 1 libra esterlina e 3 libras esterlinas são ou pequenas ou grandes demais, mas mesmo assim elas são preços do mesmo, pois são, primeiro, sua forma valor, dinheiro e, segundo, expoentes de sua relação de troca com o dinheiro. Com condições de produção constantes ou força produtiva de trabalho constante, deve-se despender para a reprodução de 1 quarter de trigo, tanto antes como depois, a mesma quantidade de tempo social de trabalho. Essa circunstância não depende da vontade do produtor de trigo nem da de outros possuidores de mercadorias. A grandeza de valor da mercadoria expressa, assim, uma relação necessária e imanente a seu processo de formação com o tempo de trabalho social. Com a transformação da grandeza do valor em preço, essa relação necessária aparece como a relação de troca de uma mercadoria com a mercadoria monetária, que existe fora dela. Mas nesta relação pode expressar-se tanto a grandeza de valor da mercadoria como o mais ou o menos em que, sob dadas circunstâncias, ela é alienável. A possibilidade de uma incongruência quantitativa entre o preço e a grandeza de valor é, portanto, inerente à própria forma preço. Isto não é um defeito desta forma, mas torna-a, ao contrário, a forma adequada a um modo de produção em que a regra somente pode impor-se como lei cega da média à falta de qualquer regra [O Capital I-I, p. 91; El Capital I-I, pp. 124-5].

Esta citação é importante para deixar claro como é falsa a idéia, muito difundida, de que Marx, no Livro I de $O$ Capital, pressupõe a troca das mercadorias por preços proporcionais aos seus valores, ou, o que dá no mesmo, que ele define a vigência da lei do valor como sendo a troca das mercadorias na proporção das quantidades de trabalho contidas na sua produção ${ }^{24}$. Ao contrário: desde a primeira vez em que fala de preço, Marx deixa claro que pode haver (na verdade, deve haver) incongruências quantitativas entre valor e preço.

Assim, quando o valor se expressa como preço, perde-se em "fidedignidade" do valor - pois o preço expressa o valor como algo diferente dele próprio, e entre ambos pode haver portanto uma diferença. Que acontece, então, quando o valor se expressa em um preço que difere dele quantitativamente? Simplesmente: se uma mercadoria é alienada por um preço distinto do seu valor, faz-se uma transferência de valor entre o comprador e o vendedor. Nesse caso, ocorre o que se pode chamar de troca desigual, isto é, troca + trans-

\footnotetext{
${ }^{24}$ Voltaremos, no Capítulo 5, à questão do significado da lei do valor.
} 
ferência de valor na circulação. A lei do valor significa que não pode haver criação de valor sem trabalho produtivo ${ }^{25}$, e que portanto não pode haver criação de valor na circulação. Mas não impede que haja desvios entre preços e valores, transferências de valor na circulação.

Mais ainda: a diferença entre preços e valores não é apenas quantitativa; pode ser também qualitativa:

A forma preço, porém, não só admite a possibilidade de incongruência quantitativa entre grandeza de valor e preço, isto é, entre grandeza do valor e sua própria expressão monetária, mas pode encerrar uma contradição qualitativa, de modo que o preço deixa de todo de ser expressão do valor, embora dinheiro seja apenas a forma valor das mercadorias. Coisas que, em si e para si, não são mercadorias, como por exemplo consciência, honra etc., podem ser postas à venda por dinheiro pelos seus possuidores e assim receber, por meio de seu preço, a forma mercadoria. Por isso, uma coisa pode, formalmente, ter um preço, sem ter um valor [O Capital I-I, p. 91; El Capital I-I, p. 125].

Ou seja, também coisas que não são produtos do trabalho, ou que não são produzidas para a troca, podem assumir a forma de mercadoria. Adquirem um preço, que não corresponde neste caso a nenhum valor, e é regulado apenas pela oferta e procura. Os possuidores destas coisas "mercantilizadas" participam portanto da divisão geral do valor (apropriam-se de valor pela sua venda), sem terem participado (enquanto proprietários destas coisas) na produção de valor.

Além de Marx mencionar a possibilidade da existência de desvios entre preços e valores logo depois de definir preço, outra prova da grande importância que ele dava a esta questão é toda sua argumentação, desde a Miséria da Filosofia, contra a idéia proudhoniana (e de vários outros autores) de que o dinheiro poderia ser substituído por bônus de trabalho ou outras formas similares, nas quais o tempo de trabalho seria representado diretamente e de maneira fiel. Em Para a Crítica da Economia Política este tema é tratado lon-

\footnotetext{
${ }^{25}$ A discussão das condições em que o trabalho é produtivo ultrapassa os limites desta tese; há na literatura ótimos tratamentos desta questão como, por exemplo, o segundo capítulo da obra de Shaikh e Tonak, Measuring the Wealth of Nations [1994, pp. 20-37]. Aqui, basta lembrar que o trabalho só é produtivo no interior do processo de produção (o que inclui atividades que se caracterizem como seus prolongamentos, como o transporte).
} 
gamente; e o capítulo sobre o dinheiro dos Grundrisse (primeira versão do que seria a primeira seção de $O$ Capital) se organiza a partir da crítica a estas concepções. Nesta crítica, a necessidade de que os preços possam divergir dos valores é um dos pontos centrais.

Vejamos como o tema é tratado em Para a Crítica da Economia Política. Após resumir a proposta de "recibos de tempos de trabalho" de John Gray, Marx comenta o seguinte:

Tendo em vista que o tempo de trabalho é a medida imanente dos valores, por que fazer valer paralelamente outra medida exterior? Por que o valor de troca se desenvolve em preço? Por que todas as mercadorias estimam seu valor em uma mercadoria exclusiva que assim é transformada no modo de ser adequado do valor de troca, em dinheiro? Esse era o problema que Gray tinha para resolver. Ao invés de resolvê-lo, imaginou que as mercadorias poderiam relacionar-se mutuamente como aquilo que são. As mercadorias são diretamente produtos de trabalhos privados, isolados e independentes, que precisam confirmar-se como trabalho social geral através de sua alienação no processo de troca privada. Em outras palavras, o trabalho, base da produção de mercadorias, só depois da alienação multilateral dos trabalhos individuais é que se torna trabalho social. Mas se Gray supõe o tempo de trabalho contido nas mercadorias como diretamente social, supõe-no como tempo de trabalho comunitário, isto é, como tempo de trabalho de indivíduos diretamente associados. Só assim seria possível que uma mercadoria, específica como o ouro ou a prata, se defrontasse com outras sem se transformar na encarnação do trabalho geral; o valor de troca não se tornaria preço, mas nem o valor de uso chegaria a ser o valor de troca, e o produto não seria mais mercadoria, eliminando com isso a própria base da produção burguesa. Mas não é essa, absolutamente, a opinião de Gray. Os produtos devem ser produzidos como mercadorias, mas não devem ser trocados como mercadorias [Para a Crítica da Economia Politica, p. 68].

Marx complementa sua argumentação no início do Capítulo III do Livro I de $\mathrm{O} C a$ pital, na nota 50 [O Capital I-I, p. 86; El Capital I-I, p. 115-6]:

A pergunta por que o dinheiro não representa diretamente o próprio tempo de trabalho, de forma que, por exemplo, uma nota de papel represente $x$ horas de trabalho, se reduz simplesmente à pergunta por que, na base da produção de mercadorias, os produtos do trabalho precisam representar-se como mercadorias, pois a representação de mercadorias implica sua duplicação em mercadoria e mercadoria monetária. Ou por que o trabalho privado não pode ser tratado como seu contrário, trabalho diretamente social. Já tratei minuciosamente, em outra parte [Marx refere-se aqui a Para a Crítica da Economia Política], do utopismo 
superficial de uma "moeda trabalho", com base na produção de mercadorias. Observaria ainda que a "moeda trabalho" de Owen é tão pouco dinheiro como um bilhete de teatro. Owen pressupõe trabalho diretamente socializado, uma forma de produção diametralmente oposta à produção de mercadorias. $\mathrm{O}$ certificado de trabalho constata apenas a participação individual do produtor no trabalho comum e seu direito individual à parte do produto comum destinada ao consumo.

Marx complementa dizendo que Owen pressupõe a produção de mercadorias e, apesar disto, quer "escamotear suas condições necessárias por meio de artimanhas monetárias".

A impossibilidade do uso dos "certificados de trabalho" decorre da dupla natureza social do trabalho produtor de mercadorias. Ele é social enquanto produtor de valores de uso, na medida em que satisfaz as necessidades sociais desenvolvidas pela divisão social do trabalho. Mas este caráter social do trabalho, não sendo o trabalho diretamente comunitário, planejado, só pode se realizar a partir de sua socialidade no sentido especificamente mercantil, de trabalho para a troca, produtor de valor, abstrato - as mercadorias só podem realizar-se como valores de uso realizando-se como valores. Esta socialidade abstrata, no entanto, exige que o trabalho passe por um processo de igualação social, pelo qual só é reconhecido o tempo de trabalho médio, isto é, de intensidade, habilidade e tecnologia médias $^{26}$. Mesmo o trabalho médio, contudo, pode exceder as necessidades sociais, ou ficar aquém delas; deve receber um reconhecimento quantitativo no momento da venda. Com isto, o tempo de trabalho efetivamente realizado pode ser reconhecido como um tempo menor, ou maior. Por estas duas razões - o trabalho individual tem de ser reduzido a trabalho médio, socialmente necessário ${ }^{27}$, e tem de haver uma comprovação social de que o trabalho despendido atendeu a necessidades sociais - deve haver uma forma social de medir o tempo de trabalho reconhecido dando-lhe a possibilidade de ser diferente do tempo de trabalho efetivamente realizado. Esta forma social, naturalmente, é o dinheiro. Sua existência resolve o problema, permitindo em primeiro lugar que o tempo de trabalho abstrato medido não seja igual ao tempo efetivamente despendido, mas sim ao tempo de tra-

\footnotetext{
${ }^{26}$ Deixamos de lado no momento, para simplicidade, a questão da distinção entre trabalho qualificado (complexo) e trabalho simples.

${ }^{27}$ E o trabalho complexo reduzido a trabalho simples.
} 
balho médio, socialmente necessário; e em segundo lugar que o preço (que mede a quantidade de trabalho socialmente reconhecida) possa desviar-se do valor (que mede a quantidade de trabalho socialmente médio efetivamente despendido).

Voltaremos a tratar da questão da igualação e do reconhecimento social do trabalho realizado, bem como da distinção entre preços e valores, nos Capítulos 3 e 5 . Também as questões da transformação dos valores em preços de produção, da formação dos preços comerciais (da distinção entre os preços dos produtores e dos preços de venda dos comerciantes), dos preços pós-impostos e dos preços internacionais giram em torno de desvios quantitativos dos preços em relação aos valores (as duas primeiras são tratadas no Livro III de $O$ Capital, as duas últimas anunciadas, mas não tratadas sistematicamente por Marx voltaremos a estas questões brevemente adiante neste Capítulo, e de forma mais extensa nos Capítulos 4 e 5).

\subsection{2 - Entesouramento e acumulação}

A análise das funções do dinheiro realizada no Capítulo III do Livro I de O Capital interessa ao tema deste trabalho também pela relação entre entesouramento e acumulação; o entesouramento é uma das funções que o dinheiro cumpre na sua "terceira determinação, a de "dinheiro como dinheiro".

O dinheiro como dinheiro é a unidade (contraditória) de suas funções anteriores:

A mercadoria que funciona como medida do valor e também, corporalmente ou por intermédio de representantes, como meio circulante, é dinheiro. (...) Como dinheiro funciona, por um lado, onde aparece em sua corporalidade áurea (ou prateada), isto é, como mercadoria monetária, portanto, nem apenas de forma ideal, como na medida do valor, nem sendo suscetível de representação, como no meio circulante; por outro lado, onde sua função, quer a execute em pessoa, quer por meio de representantes, fixa-o como figura de valor exclusiva ou única existência adequada do valor de troca perante todas as demais mercadorias, enquanto simples valores de uso [O Capital I-I, p. 109; El Capital I-I, p. 158].

A questão da importância da "corporalidade áurea" do dinheiro para Marx (ligada à função do dinheiro como dinheiro mundial) coloca problemas para uma interpretação atual: parece claro que o ouro já não desempenha nenhum papel decisivo no sistema mo- 
netário internacional de hoje $\mathrm{e}^{28}$. Para os objetivos deste trabalho esta questão não é decisiva, e podemos deixá-la de lado, ficando aqui apenas com a definição do dinheiro como dinheiro como figura única do valor, ou única existência adequada do valor de troca, "quer execute esta função corporalmente, quer por meio de representantes".

Nesta sua terceira determinação, como dinheiro propriamente, o que interessa mais de perto ao tema deste trabalho é o entesouramento. Na formação de um tesouro:

O dinheiro imobiliza-se ou transforma-se, como disse Boisguillebert, de meuble em immeuble, de moeda em dinheiro, assim que se interrompe a série de metamorfoses e a venda não se completa com a compra seguinte.

Com o desenvolvimento inicial da própria circulação de mercadorias, desenvolve-se a necessidade e a paixão de fixar o produto da primeira metamorfose, a forma modificada da mercadoria ou a sua crisálida áurea. Vendem-se mercadorias não para comprar mercadorias, mas para substituir a forma mercadoria pela forma dinheiro. De simples intermediação do metabolismo, essa mudança de forma torna-se fim em si mesma. (...) O dinheiro petrifica-se, então, em tesouro e o vendedor de mercadorias torna-se entesourador [O Capital II, pp. 109-10; El Capital I-I, p. 159].

\footnotetext{
${ }^{28}$ Não há acordo entre os intérpretes de Marx no tratamento da questão do vínculo do dinheiro com o ouro na atualidade; há os que consideram que, ainda que de forma mais indireta que antes, o ouro continua a ter um papel monetário decisivo. É o caso de Claus Germer, em diversos trabalhos; por exemplo, Germer [1998]. Leda Paulani, por outro lado, argumenta de forma convincente que o vínculo do dinheiro com o ouro não é mais necessário: “(...) as limitações que a natureza do capitalismo (...) [da época de Marx] impôs a sua apresentação teórica são muito claras. Para ele, a vinculação do dinheiro a uma mercadoria particular (o ouro) impunha-se como uma necessidade. Portanto, apesar de forma autônoma do valor, o dinheiro não podia ser assim tão autônomo. Na aparência o dinheiro tinha de ser mercadoria (como de fato tem de sê-lo ainda hoje) mas mercadoria 'de verdade', ou seja, o ouro. Assim, se ele tinha consciência do caráter puramente formal do dinheiro, que se realiza quando de sua determinação de meio de pagamento geral, acreditava também que, quando era necessário o 'valor em pessoa', era o ouro a única aparência capaz de conferir ao dinheiro esta dignidade. Enquanto dinheiro mundial, por exemplo, era sempre necessário que ele existisse em sua corporeidade metálica, de modo que não fosse apenas forma do valor mas o próprio valor, situação diferente da existente no âmbito interno, onde ele era substituído por signos do valor. (...) não pôde Marx perceber que a essência da aparência de mercadoria do dinheiro é, ela própria, puramente forma e não pôde perceber isso porque efetivamente a realidade do capitalismo do século XIX obrigava que o dinheiro se mostrasse como ouro" [Paulani 1991, pp. 146-7].
} 
O impulso à formação do tesouro não tem nenhuma relação com necessidades da circulação. É uma busca da acumulação de riqueza na sua forma mais universal, na sua única forma adequada. Esse impulso é, por sua própria natureza, ilimitado:

O impulso para entesourar é por natureza sem limite. Qualitativamente, ou segundo a sua forma, o dinheiro é ilimitado, isto é, representante geral da riqueza material, pois pode trocar-se diretamente por qualquer mercadoria. Porém, ao mesmo tempo, toda a soma efetiva de dinheiro é quantitativamente limitada, portanto também apenas meio de compra de eficácia limitada. Essa contradição entre a limitação quantitativa e o caráter qualitativamente ilimitado do dinheiro impulsiona incessantemente o entesourador ao trabalho de Sísifo da acumulação [O Capital I-I: 111-2; El Capital I-I: 162].

Um dos grandes temas de Marx para caracterizar a economia capitalista é justamente o fato de esse impulso para acumular riqueza fazer parte necessariamente da sua lógica. O dinheiro como forma geral da riqueza desperta a paixão pelo tesouro, e o impulso a entesourar é por natureza ilimitado. Mas entesourar é retirar dinheiro da circulação; é vender sem comprar, é despojar-se de uma mercadoria renunciando à aquisição do valor de uso de uma outra; "o enriquecimento se apresenta como empobrecimento voluntário" [Grundrisse, p. 936]. Assim, a acumulação do dinheiro pelo dinheiro é ainda uma "forma bárbara”.

Com o decorrer do desenvolvimento da economia capitalista, o impulso para entesourar será transformado em um impulso superior, o impulso para acumular capital, para ampliar a riqueza de forma recorrente. Por isto mesmo a produção capitalista é produção de valor e mais-valia, produção para acumulação (e não produção de valores de uso, para satisfazer necessidades).

\section{$1.4-O$ CAPITAL}

\subsection{1 — Substância do valor e capital}

A limitação do entesouramento é superada na circulação do capital, que segue a fórmula: $D-M-D+\Delta D$ (dinheiro - mercadoria - dinheiro acrescido de uma maisvalia). Esta fórmula $D-M-D+\Delta D$ ou, mais sinteticamente, $D-M-D$ ', é chamada de fórmula geral do capital. Embora a circulação do capital exija uma constante metamorfose do valor, de dinheiro a mercadoria, de mercadoria a dinheiro, o dinheiro é sua forma 
por excelência, pois é a partir dela que o sentido do movimento, isto é, o acréscimo permanente de valor, pode ser apreendido. O dinheiro é a forma autônoma do capital.

Na circulação $D-M-D(\ldots)$ ambos, mercadoria e dinheiro funcionam apenas como modos diferentes de existência do próprio valor, o dinheiro o seu modo geral, a mercadoria o seu modo particular, por assim dizer apenas camuflado, de existência. Ele passa continuamente de uma forma para outra, sem perder-se nesse movimento, e assim se transforma num sujeito automático. Fixadas as formas particulares de aparição, que o valor que se valoriza assume alternativamente no ciclo de sua vida, então se obtêm as explicações: capital é dinheiro, capital é mercadoria. De fato, porém, o valor se torna aqui o sujeito de um processo em que ele, por meio de uma mudança constante das formas de dinheiro e mercadoria, modifica a sua própria grandeza, (...) se autovaloriza. Pois o movimento, pelo qual ele adiciona mais-valia, é seu próprio movimento, sua valorização, portanto autovalorização. Ele recebeu a qualidade oculta de gerar valor porque ele é valor. Ele pare filhotes vivos ou põe ovos de ouro.

Como sujeito dominante ${ }^{29}$ de tal processo, em que ele ora assume, ora se desfaz da forma dinheiro e da forma mercadoria, mas se conserva e se dilata nessa mudança, o valor precisa, antes de tudo, de uma forma autônoma, por meio da qual a sua identidade consigo mesmo é constatada. E essa forma ele só possui no dinheiro. Este constitui, por isso, o ponto de partida e o ponto final de todo o processo de valorização [O Capital I-I, p. 126; El Capital I-I, p. 188].

Se na circulação simples o valor das mercadorias adquire, no máximo, em confronto com seu valor de uso, a forma autônoma de dinheiro, aqui ele se apresenta subitamente como uma substância em processo e semovente, para a qual mercadoria e dinheiro são ambas meras formas $(\ldots)$.

O valor torna-se, portanto, valor em processo, dinheiro em processo e, como tal, capital. Ele provém da circulação, entra novamente nela, sustenta-se e se multiplica nela, retorna aumentado dela e recomeça o mesmo ciclo sempre de novo. $D-D^{\prime}$, dinheiro que gera dinheiro - money which begets money —, diz a descrição do capital na boca de seus primeiros tradutores, os mercantilistas [O Capital I-I :126-7; El Capital I-I: 189].

O capital é desta forma definido como valor que se movimenta, mudando de forma, para se valorizar. Além disso, nós nos deparamos neste momento com um novo desenvol-

\footnotetext{
${ }^{29}$ Na edição brasileira lia-se "usurpador" no lugar de "dominante".
} 
vimento da substância social que constitui o valor: ao tornar-se capital, ela adquire uma dinâmica própria, se transforma em substância semovente e sujeito automático. Deixemos por hora a questão do sentido deste novo desenvolvimento, e ocupemo-nos apenas com a questão do caráter de substância que o capital tem.

De fato, a necessidade de identificar uma substância do valor fica muito mais clara quando analisamos o conceito de capital. Pois capital é valor que se valoriza; e falar em valorização implica comparar valores em momentos distintos, exige comparações intertemporais do valor, implica portanto explicar o que se mantém nas várias metamorfoses (de dinheiro a mercadorias e de mercadorias a dinheiro) que o capital tem de realizar para poder se valorizar; só o valor como substância pode percorrer um ciclo em que assume várias formas (dinheiro, mercadorias, capital produtivo), conservando-se sempre na passagem de uma para a outra ${ }^{30}$.

Por isso Marx retoma no Capítulo IV do Livro II de $O$ Capital, quando trata do ciclo do capital industrial (toda esta parte é um desdobramento do Capítulo IV do Livro I) a crítica a Bailey que ele realizara antes nas Teorias da Mais-Valia ${ }^{31}$.

'Value', diz Bailey contra a autonomização do valor que caracteriza o modo de produção capitalista e que ele trata como ilusão de certos economistas, 'is a relation between

${ }^{30}$ Hans Backhaus trata disso brilhantemente: "O capital é de um lado dinheiro, do outro mercadoria. Aparentemente ainda uma outra coisa. É justamente o que é irritante. Não é nem uma coisa nem outra, e contudo é tanto uma quanto a outra. Logo, 'alguma coisa invasora', dir-se-ia. Para pensar esta 'alguma coisa', somos levados a pensar o que não pode ser pensado sobre a base da teoria subjetiva do valor: o 'valor absoluto'. Alguma coisa que toma em um momento dado a forma ouro - sem ser todavia idêntico a este ouro como ouro - para retomar logo sua forma de mercadoria, ou de força de trabalho. Na troca simples de mercadorias, este dilema parece ainda não se colocar: a mercadoria aparece como coisa e se distingue desta outra coisa que é o ouro. Aqui, acreditamos que ainda é possível prescindir da análise da 'interdependência interna' e do 'movimento interno'. No caso do capital, em compensação, nós nos vemos constrangidos a construir uma 'soma abstrata de valor', que não poderia ser idêntica ao ouro como ouro, porque ela deve entretanto poder 'encarnar-se' também em outros bens de capital. 'Todo capital muda incessantemente de forma', escreve Zwiedeneck. Pode entretanto parecer estranho que partidários da economia subjetiva falem de 'mudança de forma', dando conta da fórmula marxiana da relação do capital $\mathrm{D}$ - M — D', mas não possam dar o nome ao sujeito que tem a particularidade de realizar esta 'mudança de forma"' [Backhaus 1974, p. 29].

${ }^{31}$ Como se sabe, a redação do Livro II de O Capital é posterior à das Teorias da Mais-Valia. 
contemporary commodities, because such only admit of being exchanged with each other, 32 .

Ele diz isto contra a comparação de valores de mercadorias em diferentes épocas, uma comparação que, uma vez fixado o valor monetário para cada época, significa apenas uma comparação entre o gasto de trabalho exigido nas diferentes épocas para o mesmo tipo de mercadoria. Isso se origina de seu equívoco geral, segundo o qual valor de troca $=$ valor, como se a forma de valor fosse o próprio valor; valores de mercadorias não são, portanto, comparáveis, quando já não funcionam como valores de troca e, por conseguinte, não podem ser realiter intercambiados entre si. Ele não suspeita de que o valor só funciona como valor-capital ou capital à medida que, nas diferentes fases do seu ciclo (que, de jeito nenhum são contemporary, mas se sucedem umas às outras), ele permanece idêntico a si mesmo e é comparado a si mesmo [O Capital II-III, p. 74].

Compreender o capital exige então o conceito de substância do valor, de um conteúdo que pode assumir sucessivamente várias formas, que pode se objetivar de diversas maneiras. Exige também que essa substância seja real, objetiva - mesmo que sua objetividade seja puramente social. Só desta maneira ela pode autonomizar-se, e só assim o valor-capital pode ser acumulado como capital propriamente, isto é, como valor, como dinheiro - e não apenas como estoque de mercadorias. Um pouco antes da crítica a Bailey, no mesmo capítulo, podemos ler:

Aqueles que consideram a autonomização do valor como mera abstração esquecem que o movimento do capital industrial é esta abstração in actu. (...) Caso o valor-capital sofra uma revolução de valor, então pode ocorrer que seu capital individual sucumba ante ela e submerja por não poder preencher as condições desse movimento de valor. Quanto mais agudas e freqüentes se tornam as revoluções de valor, tanto mais se impõe, atuando com a violência de um processo natural elementar, o movimento automático do valor autonomizado em face da previsão e do cálculo do capitalista individual, tanto mais se torna o curso da produção normal vassalo da especulação anormal, tanto maior se torna o perigo para a existência dos capitais individuais. Essas periódicas revoluções de valor confirmam, portanto, o que pretensamente devem refutar: a autonomização que o valor enquanto capital

\footnotetext{
32 "Valor é uma relação entre mercadorias contemporâneas, pois somente estas são passíveis de serem trocadas umas pelas outras".
} 
experimenta e que por seu próprio movimento conserva e acentua [O Capital II-III, pp. 73$4]$.

O valor tem uma substância que encontra uma existência autônoma no dinheiro. E a realidade específica do valor se demonstra do modo mais nítido no fato de que podem ocorrer revoluções de valor (isto é, processos de desvalorização - ou eventualmente de revalorização - do capital): o valor do capital se altera, sem que seus elementos materiais sofram modificações ${ }^{33}$.

\subsection{2 - O capital como sujeito}

Ocupemo-nos agora com a questão do desenvolvimento assumido pelo valor enquanto substância social quando ele se torna capital: torna-se uma substância semovente e um sujeito automático. Deparamo-nos, assim, com novas razões de estranheza. Qual o sentido destas expressões? Marx está certamente se referindo ao fato de que a estrutura de relações sociais reificadas, alienadas, à qual os indivíduos são submetidos, adquire uma dinâmica própria. Aponta a constituição, no capitalismo, de uma dialética de desenvolvimento, de uma lógica, que se sobrepõe às vontades individuais O valor é uma "abstração", mas não apenas é uma abstração real, como além disso se movimenta, e ao se movimentar, subordina os sujeitos humanos ao seu movimento, torna-se ele próprio sujeito. Esta subordinação dos indivíduos ao resultado alienado das suas relações sociais constitui um novo desenvolvimento do fetichismo.

Ao juntar dois termos que em geral se excluem — "sujeito" e "automático" —, Marx está chamando a atenção para as peculiaridades deste sujeito. Como expressão de relações sociais reificadas e alienadas, não se trata de um sujeito no sentido de sujeito moral, uma vez que lhe falta vontade, subjetividade, ao contrário dos indivíduos que lhe são submetidos. De fato, vale o que Postone aponta de modo brilhante, na sua contraposição entre o capital e o Geist hegeliano: como sujeito, o capital é um sujeito notável.

\footnotetext{
${ }^{33}$ Naturalmente, esse caráter do valor e do capital é um fetiche — mas um fetiche real. Essa autonomização do valor que se impõe sobre os capitalistas individuais se explica porque reflete uma complexa teia de relações sociais mediadas pelo mercado, que escapam portanto ao controle de cada capitalista. Voltaremos a esta questão no Capítulo 3.
} 
Como Sujeito, o capital é um "sujeito" notável. Enquanto o Sujeito de Hegel é trans-histórico e cognoscente, na análise de Marx ele é historicamente determinado e cego. O capital, como uma estrutura constituída por determinadas formas de prática, pode por sua vez ser constitutivo de formas de prática e de subjetividade embora, como Sujeito, ele não tenha ego. Ele é auto-reflexivo e, como uma forma social, pode induzir à autoconsciência, mas diferentemente do Geist de Hegel, não possui autoconsciência. A subjetividade e o Sujeito sócio-histórico precisam, em outras palavras, ser distinguidos na análise de Marx [Postone 1993, p. 77].

Vale a pena enfatizar: a emergência do capital como sujeito impõe uma marca a todo o funcionamento da economia, transforma seu objetivo em acumulação de riqueza na forma geral, abstrata, de dinheiro. A finalidade da atividade econômica em uma economia capitalista é portanto a valorização do capital, e não a produção de bens para o seu posterior consumo, ou a "maximização da utilidade" trazida por este consumo.

\subsection{3 - Valorização do capital e subsunção real do trabalho ao capital ${ }^{34}$}

Para se valorizar o capital precisa produzir; a mais-valia se forma no processo de produção, a partir do intercâmbio entre o capital e a força de trabalho. Isto é bem conhecido, e não será retomado aqui. O que importa salientar neste momento é que a produção capitalista tem um caráter especial, distinto da produção em outros tipos de organização econômica. No Capítulo V do Livro I de O Capital, Marx chama a atenção para o fato de que, nas condições da economia capitalista, o processo produtivo ganha também um duplo caráter: é processo de produção material e processo de valorização do capital, ou seja, processo de produção de valores de uso e processo de produção de valor. Na primeira parte do capítulo, ele examina o processo de trabalho no primeiro aspecto; na segunda parte, no segundo aspecto, com o que o ângulo de análise passa ser totalmente diverso. Pela ótica do processo de valorização, em primeiro lugar, o trabalho interessa apenas como dispêndio de trabalho socialmente necessário.

Agora temos de observar esse trabalho sob um aspecto totalmente diverso daquele sob o qual o consideramos durante o processo de trabalho. Lá, tratava-se da atividade orientada ao fim de transformar algodão em fio. Quanto mais adequado o trabalho a esse fim, tanto

\footnotetext{
34 A redação desta subseção deve muito à análise de Moishe Postone, sobretudo em “The sphere of production", in Postone [1993, pp. 277-85], e "Production and valorization" [idem, pp. 324-48].
} 
melhor o fio, supondo-se inalteradas todas as demais circunstâncias. O trabalho do fiandeiro era especificamente diferente de outros trabalhos produtivos, e a diversidade manifestava-se subjetiva e objetivamente no fim particular da fiação, em seu modo particular de operar, na natureza particular de seus meios de produção, no valor de uso particular de seu produto. (...) Na medida em que o trabalho do fiandeiro é, pelo contrário, formador de valor, isto é, fonte de valor, não se distingue em nada do trabalho do perfurador de canhões, ou, que está aqui mais próximo, dos trabalhos do plantador de algodão e do produtor de fusos, realizados nos meios de produção do fio. É apenas por causa desta identidade que plantar algodão, fazer fusos e fiar podem formar partes apenas quantitativamente diferentes do mesmo valor total, do valor do fio. Aqui já não se trata da qualidade, da natureza e do conteúdo do trabalho, mas apenas de sua quantidade. (...)

Agora é de importância decisiva que durante o processo, isto é, durante a transformação do algodão em fio, somente o tempo de trabalho socialmente necessário seja consumido. (...) Pois apenas o tempo de trabalho socialmente necessário conta como formando valor $[O$ Capital I-I, pp. 149-50; El Capital I-I, pp. 229-30].

Os meios de produção interessam apenas como absorvedores de tempo de trabalho; o produto é apenas "uma escala graduada que mede o trabalho absorvido"; "quantidades de produto determinadas (...) representam agora nada mais que (...) determinada massa de tempo de trabalho solidificado".

Como o próprio trabalho, assim a matéria-prima e o produto aparecem aqui sob uma luz totalmente diferente da projetada pelo ponto de vista do processo de trabalho propriamente dito. A matéria-prima funcionou aqui apenas como algo que absorve determinado quantum de trabalho. Por meio desta absorção transforma-se, de fato, em fio, porque a força de trabalho foi despendida e lhe foi acrescentada sob a forma de fiação. Mas o produto, o fio, é agora apenas uma escala graduada que mede o trabalho absorvido pelo algodão. (...) Quantidades de produto determinadas, verificadas pela experiência, representam agora nada mais que determinadas quantidades de trabalho, determinada massa de tempo de trabalho solidificado. São apenas a materialização de 1 hora, de 2 horas, de 1 dia de trabalho social [O Capital I-I, p. 150; El Capital I-I, p. 230].

Esse caráter do processo de produção enquanto processo de valorização obriga o capitalista, naturalmente, a uma vigilância estrita, uma vez que o tempo despendido pelo trabalhador na produção e o consumo de meios de produção só contam na medida em que são socialmente necessários. O capitalista deve cuidar para que a força de trabalho tenha caráter normal ("grau médio de habilidade, destreza e rapidez"), e para que não haja ne- 
nhum desperdício, nem de tempo, nem de material e meios de trabalho, "porque material e meios de trabalho desperdiçados representam quantidades despendidas em excesso de trabalho objetivado, que, portanto, não contam nem entram no produto da formação do valor" [O Capital I-I, p. 154; El Capital I-I, pp. 237-8].

No entanto, o capitalista não pode se contentar apenas com o ganho médio. A busca de maiores ganhos ${ }^{35}$ leva à transformação permanente das condições de produção; trata-se do processo de produção de mais-valia relativa, analisado por Marx na Seção IV do Livro I de $O$ Capital. Esta seção examina o desenvolvimento do progresso técnico, tal como realizado sob o domínio da busca de valorização do capital; a análise parte da cooperação simples, passa pela divisão do trabalho no interior da manufatura, e chega à grande indústria maquinizada.

O capital remodela de forma cada vez mais profunda o processo produtivo; molda-o segundo sua lógica; ao fazê-lo, submete o trabalho a uma dominação crescente. Ao caracterizar estas transformações no Capítulo XIV do Livro I de O Capital e no chamado Capítulo VI Inédito de O Capital, Marx lhes dá o nome de criação de "um modo de produção especificamente capitalista" e de "subsunção real do trabalho no capital" [O Capital I-II, p. 102; Capítulo VI Inédito de O Capital, pp. 104-7] $]^{36}$.

Marx descreve longamente como este processo de dominação progressiva do capital sobre o trabalhador e de transformação do processo produtivo leva à opressão e à alienação crescentes do trabalho. Não examinaremos esta questão neste trabalho. É importante mencionar apenas dois aspectos.

\footnotetext{
${ }^{35}$ Analisamos este processo no Capítulo 5, seção 5.2.

36 “A produção da mais-valia absoluta gira apenas em torno da duração da jornada de trabalho; a produção da mais-valia relativa revoluciona de alto a baixo os processos técnicos do trabalho e os agrupamentos sociais. Ela supõe portanto um modo de produção especificamente capitalista, que com seus métodos, meios e condições nasce e é formado naturalmente apenas sobre a base da subordinação real do trabalho ao capital" [O Capital I-II, p. 102; El Capital I-II, p. 618]. A edição da Siglo Veintiuno Editores fala em "subsunção" (formal ou real) no lugar de "subordinação"; o mesmo procedimento é utilizado na edição brasileira do Capítulo VI Inédito. O termo "subsunção", embora não usual em português, deve ser preferido: é um termo mais forte, e representa uma tradução mais literal do alemão.
} 
O primeiro é que o processo de dominação crescente do capital sobre os trabalhadores, de controle do processo de produção, é uma conseqüência do caráter especificamente social (e imediatamente social) que o trabalho adquire no capitalismo, enquanto trabalho abstrato; os gastos diretos e indiretos de trabalho devem ser minimizados. Como diz Moishe Postone:

(...) Marx afirma explicitamente que o caráter imediatamente social do trabalho na sociedade capitalista está no coração desta sociedade. Considera este caráter diretamente social do trabalho como central para os processos históricos que caracterizam o capitalismo, processos nos quais poderes sociais gerais e riqueza são desenvolvidos, mas à custa dos indivíduos:

"De fato, só com o mais monstruoso desperdício de desenvolvimento individual é que o desenvolvimento da humanidade é assegurado e efetivado ao todo na época histórica que precede imediatamente a reconstrução consciente da sociedade humana. Já que toda a parcimônia [JM: Marx refere-se à economia de capital constante; o título da parte do capítulo em que esta passagem está é: "Economia nas condições de trabalho à custa do trabalhador".], de que aqui se fala, deriva do caráter social do trabalho, então é, de fato, exatamente este caráter imediatamente social do trabalho que gera esse desperdicio de vida e saúde dos trabalhadores" [O Capital, III-IV, p. 67; o grifo é de Postone] [Postone 1993, pp. 478].

O segundo aspecto, é que com as transformações no processo de produção que levam à constituição de um "modo de produção especificamente capitalista", as formas tecnológicas adotadas passam a ser características do capital, que é o sujeito do processo, e não o fruto de alguma necessidade puramente técnica ${ }^{37}$. Como observa Postone:

Com o desenvolvimento da produção em grande escala, os trabalhadores tornaram-se os objetos de um processo que se tornou ele próprio o "sujeito", de acordo com Marx. Ele se refere à fábrica como um autômato mecânico que é o sujeito, composto de vários órgãos conscientes (os trabalhadores) e inconscientes (os meios de produção), todos subordinados a sua força motora central. Em outras palavras, Marx descreve a fábrica industrial nos

\footnotetext{
${ }^{37}$ Aproveitemos para assinalar uma diferença importante entre a economia neoclássica e a de Marx: na análise neoclássica, as "tecnologias" são em geral tomadas como dadas, como pré-existentes à decisão das empresas, que apenas selecionam a mais lucrativa; para Marx, elas são antes de qualquer coisa moldadas pelo processo de valorização capitalista, pela lógica do capital.
} 
mesmos termos que usou antes para descrever o capital, implicando portanto que aquela deve ser vista como a expressão física deste último. Logo, analisando a grande indústria, Marx busca compreender em termos sociais um sistema caracterizado por enormes forças produtivas, de um lado, e por trabalho humano direto fragmentado, vazio, do outro. A natureza do trabalho e da divisão social do trabalho no capitalismo industrial não são subprodutos necessários (ainda que indesejados) de nenhum método de produzir riqueza, de acordo com Marx; antes, são expressões do processo de trabalho moldado pelo processo de valorização [Postone 1993, pp. 345-6].

Esta questão tem implicações muito importantes para o entendimento do trabalho abstrato e do valor, às quais retornaremos no Capítulo 3.

Finalmente, a dominação do processo de produção de valores de uso pelo processo de valorização tem ainda uma conseqüência fundamental: a "produção pela produção".

"A produção pela produção" — a produção como fim em si mesma — já entra, é claro, em cena com a subordinação formal do trabalho no capital, logo que o objetivo imediato da produção é produzir a maior quantidade possível de mais-valia, logo que o valor de troca ${ }^{38}$ do produto se torna o objetivo decisivo. Mas esta tendência inerente à relação capitalista só se realiza de maneira adequada — convertendo-se numa condição necessária inclusivamente do ponto de vista tecnológico - logo que se desenvolve o modo de produção especificamente capitalista e, com ele, a subordinação real do trabalho ao capital ${ }^{39}$ [Capitulo VI Inédito de O Capital, p. 107].

Reencontramos, portanto, a idéia de que, no capitalismo, a finalidade da atividade econômica é a valorização do capital $^{40}$, e lhe acrescentamos uma nova determinação: a produção (de valores de uso) pela produção (de fato, pela valorização; é por isto que não é limitada pelas necessidades socais).

Em suma, Marx argumenta que o que caracteriza a produção capitalista é que "a transformação da matéria pelo trabalho é apenas um meio para a criação da forma social

\footnotetext{
${ }^{38}$ Mais correto seria dizer "valor do produto". Ver nota 21, acima.

${ }^{39}$ Embora no título da seção esta edição esteja "subsunção", aqui foi deixado o termo "subordinação".

${ }^{40}$ Este é, naturalmente, um tema central de O Capital. Na Seção I do Livro II, Marx retomará esta idéia, assinalando que a própria produção (necessária, aliás, para que o movimento de valorização possa ter lugar) torna-se um momento da circulação do capital.
} 
constituída pelo trabalho (o valor)" [Postone 1993, p. 280]. O objetivo de valorização domina o objetivo de produzir valores de uso, transforma-o num meio.

\subsection{4 - Negação da propriedade baseada no próprio trabalho}

A análise do processo de subsunção real do trabalho ao capital pela ótica das modificações impostas ao processo produtivo não esgota ainda, contudo, a questão da subordinação do trabalhador e de sua inclusão no movimento do capital. Fica faltando um aspecto, estudado por Marx nos dois primeiros capítulos da Seção VII (“O Processo de Acumulação de Capital") do Livro I de O Capital, os Capítulos XXI ("Reprodução Simples") e XXII (“Transformação da Mais-valia em Capital”) ${ }^{41}$.

Quando consideramos o movimento do capital de forma descontínua, capitalista e trabalhador aparecem como agentes livres, e sua relação como uma troca de equivalentes. Já se trata, é verdade, de uma troca de equivalentes em um sentido apenas parcial; ela se restringe à superfície da circulação, uma vez que em cada relação entre capitalista e trabalhador assalariado já se observa que o primeiro recebe um quantum de valor superior ao que paga ao segundo — ou seja, a mais-valia já pode ser discernida.

Do mesmo modo, a liberdade do trabalhador, mesmo quando consideramos uma relação isolada com um capitalista, já é limitada, ou melhor, contraditória e formal; pois para que o trabalhador venda sua força de trabalho ao capitalista ele deve estar desprovido de meios próprios de produção — Marx diz livre de meios de produção —, e ser portanto obrigado a fazê-lo por uma coação objetiva, impessoal. Sobre a liberdade do trabalhador, contudo, o ponto fundamental a frisar aqui é que, numa relação examinada isoladamente, a privação dos meios de produção aparece como externa à própria relação; a possibilidade de

\footnotetext{
${ }^{41}$ Ruy Fausto chama a atenção para a importância destes capítulos em dois ensaios do Tomo I de Marx, Lógica e Política. No primeiro ensaio, "Dialética Marxista, Humanismo, Anti-humanismo", sobretudo nas pp. 46-54, e no quarto ensaio, “Circulação de Mercadorias, Produção Capitalista”, sobretudo nas pp. 186-95. Estes ensaios são uma referência importante para esta subseção, embora haja algumas diferenças entre a exposição feita aqui e a argumentação de Fausto. Outro autor que chama a atenção para a importância destes capítulos é Roman Rosdolsky, em “O processo de reprodução e a inversão da lei de apropriação” [Rosdolsky 2001, Capítulo 19].
} 
o capitalista comprar a força de trabalho se beneficia, por assim dizer, de uma circunstância que é favorável para o capitalista, mas que ele não provocou.

Por isso, e porque a relação entre capitalista e trabalhador mantém ainda a forma de uma troca de equivalentes, a negação que a circulação capitalista, quando considerada de forma descontínua, realiza da circulação simples (na qual agentes livres trocam livremente equivalentes) ainda é parcial. Como observa Ruy Fausto, "a passagem da circulação simples à produção capitalista não é aí plenamente realizada" [Fausto 1983d, p. 186] ${ }^{42}$.

No entanto, a mera continuidade do movimento do capital — sua reprodução, ainda que nos limites da reprodução simples -, completa a negação da circulação simples. A troca de equivalentes é reduzida a uma mera aparência, a extração de mais-valia se mostra como extorsão de trabalho, e o contrato entre agentes livres "é agora a aparência de um ato que não é mais de liberdade" [Fausto, 1983d, pp. 191-2; no mesmo sentido, Fausto, 1983b, pp. 47-8]. Isto porque, como explica Marx, com a repetição do processo, fica claro que:

1) O capitalista paga como salário uma parte do produto que o próprio trabalhador lhe entrega. $\mathrm{O}$ fato de ele pagar com dinheiro que tinha previamente oculta este fato; parece que ele paga ao trabalhador com seus próprios recursos. Mas isto se revela, na verdade, uma ilusão.

A ilusão, gerada pela forma monetária, desaparece imediatamente tão logo sejam consideradas a classe capitalista e a classe trabalhadora em vez do capitalista individual e do trabalhador individual. A classe capitalista dá constantemente à classe trabalhadora, sob forma monetária. títulos sobre parte do produto produzido por esta e apropriado por aquela. Esses títulos, o trabalhador os restitui, do mesmo modo constante, à classe capitalista e re-

\footnotetext{
${ }^{42}$ Contudo, como já no exame de um ato isolado de intercâmbio entre capitalista e assalariado a mais-valia é extraída, e o trabalhador já aparece despojado de meios de produção, não podemos concordar com Fausto quando diz: "De um modo geral, deve-se dizer que o que se modifica, ao passar da circulação simples à produção capitalista enquanto produção capitalista, é a finalidade do processo que se encontra no objeto. Nos limites da circulação simples de mercadorias (...) a finalidade da produção e da circulação é o valor de uso, isto é, a satisfação das necessidades. Na produção capitalista enquanto produção capitalista (...) a produção que visa o valor de uso se revela na realidade como produção que visa a valorização do valor" [Fausto, 1983d, pp. 186-7]. Esta inversão da finalidade certamente ocorre, e é fundamental; mas não é a única mudança. Outras mudanças começam aí, embora só se completem depois.
} 
tira-lhe, com isso, aquela parte de seu próprio produto que é atribuída a ele. A forma mercadoria do produto e a forma monetária da mercadoria disfarçam a transação.

O capital variável, portanto, é apenas, uma forma histórica particular em que aparece o fundo dos meios de subsistência ou fundo de trabalho, de que o trabalhador necessita para sua própria manutenção e reprodução e que em todos os sistemas de produção social ele mesmo sempre tem de produzir e reproduzir [O Capital I-II, p. 146; El Capital I-II, pp. 697-8].

2) Todo o capital inicial, após certo número de anos, é consumido integralmente como renda do capitalista; o capital se mantém apenas porque o capitalista recebe de volta na forma de mais-valia, em cada período, o equivalente da parcela consumida de seu capi$\operatorname{tal}^{43}$.

(...) [Q] uando o capitalista consumiu o equivalente de seu capital adiantado, o valor desse capital representa apenas a soma global da mais-valia de que se apropriou gratuitamente. Não subsiste nenhum átomo de valor de seu antigo capital [O Capital I-II, p. 147; El Capital I-II, pp. 700].

3) O trabalhador sai do processo mantido como trabalhador, que terá de vender novamente sua força de trabalho, ao mesmo tempo em que seu produto se transforma no capital que o explora. Permanentemente despojado dos meios de produção pelo próprio processo de produção capitalista, o trabalhador é portanto submetido de maneira permanente ao capital, transformado em seu acessório.

(...) $[\mathrm{O}]$ trabalhador sai do processo sempre como nele entrou - fonte pessoal de riqueza, mas despojado de todos os meios para tornar essa riqueza realidade para si. (...) [O] produto do trabalhador transforma-se continuamente não só em mercadoria, mas em capital, em valor que explora a força criadora de valor, em meios de subsistência que compram pessoas, em meios de produção que empregam o produtor. O próprio trabalhador produz, por isso, constantemente a riqueza objetiva como capital, como poder estranho, que o domina e explora (...) [O Capital I-II, p. 148; El Capital I-II, p. 701].

Do ponto de vista social, a classe trabalhadora é, portanto, mesmo fora do processo direto de trabalho, um acessório do capital, do mesmo modo que o instrumento morto de traba-

\footnotetext{
${ }^{43} \mathrm{Na}$ hipótese de reprodução simples. Se houver acumulação de capital, o capitalista recebe na forma de mais-valia mais do que consome.
} 
lho. (...) O escravo romano estava preso por correntes a seu proprietário, o trabalhador assalariado o está por fios invisíveis. A aparência de que é independente é mantida pela mudança contínua dos patrões individuais e pela fictio juris do contrato [O Capital I-II, p. 150; El Capital I-II, p. 706].

A consideração do processo como um todo, já no quadro da reprodução em escala ampliada - a "Transformação de mais valia em capital", que Marx estuda no Capítulo XXII —, permite acrescentar mais uma inversão (de fato, uma interversão, uma inversão que vem "de dentro" ${ }^{44}$ ): a lei de propriedade da economia mercantil simples se transmuta em lei da apropriação capitalista. A partir do fato de que o capital se acumula a partir da adição de mais-valia, apropriada pelo capitalista a partir do intercâmbio com a força de trabalho; e de que este intercâmbio, juridicamente, consiste numa troca de equivalentes, e respeita a lei do intercâmbio de mercadorias,

(...) [A] lei da apropriação ou lei da propriedade privada, baseada na produção de mercadorias e na circulação de mercadorias, evidentemente se converte mediante sua própria dialética interna, inevitável, em seu contrário direto. O intercâmbio de equivalentes, que apareceu como a operação original, se torceu de tal modo que se troca apenas na aparência, pois, primeiro, a parte do capital que se troca por força de trabalho nada mais é do que uma parte do produto do trabalho alheio, apropriado sem equivalente, e segundo, ela não somente é reposta por seu produtor, o trabalhador, como este tem de repô-la com novo excedente. A relação de intercâmbio entre capitalista e trabalhador torna-se portanto apenas mera aparência pertencente ao processo de circulação, mera forma, que é alheia ao próprio conteúdo e apenas o mistifica. A contínua compra e venda da força de trabalho é a forma. O conteúdo é que o capitalista sempre troca parte do trabalho alheio já objetivado, do qual se apropria incessantemente sem equivalente, por um quantum maior de trabalho vivo alheio. Originalmente, o direito de propriedade apareceu-nos fundado sobre o próprio trabalho. Pelo menos tinha de valer essa suposição, já que somente se defrontam possuidores de mercadorias com iguais direitos, e o único meio de apropriação de mercadoria alheia é a alienação da própria mercadoria, e esta pode ser produzida apenas mediante trabalho ${ }^{45}$.

\footnotetext{
${ }^{44}$ Leda Paulani explica o que é agregado com a substituição do conceito de inversão pelo de interversão: "A inversão vem de dentro das próprias leis, é interna e inerente a elas; por isso não há só aí inversão mas interversão" [Paulani 1991, p. 62].

${ }^{45}$ A redação desta frase, que estava bastante confusa na edição brasileira, foi modificada com base na edição de Siglo Veitinuno Editores.
} 
A propriedade aparece agora, do lado do capitalista, como direito de apropriar-se de trabalho alheio não pago ou de seu próprio produto; do lado do trabalhador, como impossibilidade de apropriar-se de seu próprio produto. A separação entre propriedade e trabalho torna-se conseqüência necessária de uma lei que, aparentemente, se originava em sua identidade [O Capital I-II, p. 157; El Capital I-II, pp. 720-2 $]^{46}$.

Dada a centralidade que a defesa do direito de propriedade tem na ideologia capitalista, é preciso atribuir a máxima importância a este argumento de Marx. A partir dele, é possível, entre outras coisas, chamar a atenção para o fato de que dois conceitos opostos de propriedade são em geral confundidos: a propriedade baseada no próprio trabalho e a propriedade capitalista. ( $\mathrm{O}$ fato de a segunda nascer da interversão da primeira pode explicar esta confusão, mas de nenhuma maneira justificá-la.) $\mathrm{O}$ direito de propriedade capitalista de meios de produção costuma ser fundamentado com base na defesa do "direito de propriedade" em geral ${ }^{47}$; entretanto, este direito capitalista depende da não propriedade dos trabalhadores: no dia em que todos os trabalhadores se transformarem em proprietários e

\footnotetext{
${ }^{46}$ Ruy Fausto comenta esse desenvolvimento de modo preciso: (...) "[N]o momento em que se considera o capital num fluxo contínuo, o valor que em forma de dinheiro é transferido para o operário enquanto salário aparece como valor extorquido sem equivalente no movimento anterior - extorquido talvez de um outro operário, mas todas as diferenças individuais desaparecem na perspectiva da acumulação que só considera a relação entre classe e classe - e por isso a compra da força de trabalho deixa de ser uma verdadeira compra: o que o capitalista dá ao operário (à classe operária) em forma de salário é na realidade uma parte da riqueza criada pela própria classe operária. (...) Assim, não há equivalente, nem a rigor troca, mas apropriação sem equivalente do trabalho alheio. E isto num duplo sentido: o que a classe operária recebe é riqueza produzida pela própria classe operária. (...) A riqueza produzida por uma classe é sugada continuamente por representantes de uma outra classe - esta é a maneira pela qual se apresenta agora o processo. Essa mudança de perspectiva que representa na realidade uma mudança de sentido, objetiva, do processo, constitui o que Marx chama de interversão da lei da apropriação ou da propriedade, interversão cujos dois momentos poderiam ser resumidos da seguinte maneira: uma volta do capital ou cada volta do capital obedece à lei de apropriação ou de propriedade das economias mercantis, lei segundo a qual a apropriação dos produtos se faz pela troca de equivalentes e depende, em última instância, do trabalho próprio. Mas a repetição das voltas do capital - e portanto o cumprimento reiterado da lei de apropriação pelo trabalho e pela troca de equivalentes - interverte esta lei na lei da apropriação sem equivalente do trabalho alheio [Fausto 1983b, p. 48].

${ }^{47}$ Em geral as Constituições - e a brasileira não é diferente - tratam o direito à casa própria e o direito de propriedade capitalista dos meios de produção como sendo no fundo o mesmo direito.
} 
tiverem a sua fábrica, nenhuma delas poderá funcionar ${ }^{48}$. O direito à propriedade capitalista é portanto um direito que não pode ser generalizado. Um direito que só vale para alguns, contudo, não é propriamente um direito. Além disso, seu conteúdo real de direito de apropriar-se gratuitamente de trabalho alheio torna-o ainda mais absurdo como direito.

Igualmente importante - e, além disso, com uma relação mais direta com o tema deste trabalho - é que o argumento estudado nesta seção completa a demonstração de que o capital é uma substância social semovente, um sujeito automático, que no processo de seu desenvolvimento subsume o trabalhador ao seu movimento, torna-o um órgão do seu próprio corpo.

\section{5 - A ESPECIFICIDADE DA TEORIA DA MERCADORIA, DO VALOR, DO}

\section{DINHEIRO E DO CAPITAL DE MARX}

\subsection{1 - Especificidades da economia de Marx}

A exposição realizada neste capítulo chamou a atenção para algumas características da economia marxista que a distinguem de outras vertentes teóricas; em particular, para a importância do duplo caráter do trabalho produtor de mercadorias e para a existência, na economia capitalista, de uma substância do valor, o trabalho abstrato. Do duplo caráter do trabalho decorre uma dualidade geral das categorias econômicas próprias à economia capitalista: a mercadoria tem um duplo caráter, o mesmo acontecendo com a riqueza e com o processo de produção. Por outro lado, o fato de o valor ter uma substância, o trabalho abstrato, permite explicar o dinheiro como sua concretização material, e o capital como esta substância em movimento. Como estas características (a dualidade das categorias econômicas, a existência de uma substância do valor) são peculiares à estrutura das relações econômicas capitalistas, chamar a atenção para elas implicou também chamar a atenção para a especificidade histórica do modo capitalista de produção.

Nesta seção, são agregados três comentários mais sobre a especificidade das categorias marxistas. O primeiro diz respeito à natureza da mercadoria e do dinheiro, e ao vín-

\footnotetext{
${ }^{48}$ Enquanto não houver "replicantes" (para citar o filme Blade Runner) que substituam os humanos. Se isto vier a acontecer, por outro lado, dará origem a grandes complicações. Os "replicantes" não terão o direito de se considerarem humanos e de lutar contra sua exploração?
} 
culo entre ambos; o segundo, à distinção entre preço e valor; o terceiro, à natureza do capital e à dinâmica que seu domínio impõe à economia capitalista.

\subsection{2 - Especificidade da teoria da mercadoria e do dinheiro}

Comentando a visão de Marx sobre a gênese do dinheiro, Roman Rosdolsky ${ }^{49}$ chama a atenção para aspectos da sua argumentação, já mencionados nas seções anteriores (sobretudo nas subseções 1.2.2 e 1.2.4), que aparecem ainda mais claramente nas diversas críticas feitas à teoria do dinheiro de Ricardo (que estão presentes tanto em $O$ Capital e em Para a Crítica da Economia Política quanto nas Teorias da Mais-Valia). É útil retomar esta argumentação.

Ricardo erra ao ocupar-se apenas com a magnitude do valor [a tradução em inglês é mais enfática: "Ricardo's mistake is that he is concerned only with...", isto é, "O erro de Ricardo é que se ocupa apenas ...". Economic Manuscript of 1861-63, vol. III, p. 318]. Por isso tem em mira apenas a quantidade relativa de trabalho que diferentes mercadorias configuram, contêm como valores nelas corporificados. Mas o trabalho nelas contido tem de apresentar-se como trabalho social, como trabalho individual alienado. (...) Ricardo não explica essa conversão do trabalho dos indivíduos particulares, contido nas mercadorias, em trabalho social igual e por isso em trabalho representável em todos os valores de uso e por todos eles intercambiável; esse aspecto qualitativo da coisa, o qual se encerra na configuração do valor de troca em dinheiro. Ricardo omite essa circunstância - a necessidade de apresentar o trabalho nelas contido como trabalho social igual, isto é, como dinheiro [Teorias da Mais-Valia III, p. 1186].

Esta necessidade de ser o trabalho individual representado pelo geral é a necessidade de uma mercadoria ser representada pelo dinheiro [Teorias da Mais-Valia III, p. 1191].

Para compreender o dinheiro, não basta conceber o aspecto quantitativo do valor, por exemplo vinculando-o ao tempo de trabalho necessário. Isto foi feito por Ricardo. É preciso ter em conta o aspecto qualitativo do valor, isto é, que as diversas mercadorias enquanto valores assumem uma forma em que existem como encarnação do trabalho social, e são por isto intercambiáveis por qualquer outra mercadoria. Ou seja, adquirem a forma de

\footnotetext{
${ }^{49}$ No capítulo "A transição do valor ao dinheiro", segunda seção, “Os aspectos quantitativo e qualitativo do problema do valor (magnitude e forma do valor)" [Rosdolsky 2001, p. 111-115].
} 
trabalho geral, abstrato. A necessidade de os produtos do trabalho se apresentarem desta forma só existe, naturalmente, em uma sociedade em que são mercadorias. Esta sociedade só pode existir com o dinheiro.

Em que medida a teoria da gênese do dinheiro desenvolvida por Marx se distingue da argumentação convencional, de que o dinheiro se torna necessário a partir da complicação trazida pela generalização das trocas? Esta argumentação diz, resumidamente, que na troca entre poucas pessoas, o que A tem e não quer deve ser desejado por B, e vice-versa, o que B tem e não quer deve ser desejado por A. Quando poucas pessoas participam do processo de troca, encontrar correspondências deste tipo é possível. Mas quando são muitos os participantes, tais correspondências passam a ser difíceis ou impossíveis; daí um intermediário das trocas, aceito por todos, fazer-se necessário.

Em Para a Crítica da Economia Política, Marx critica esta maneira de conceber a gênese do dinheiro:

Os economistas costumam derivar o dinheiro das dificuldades exteriores com as quais se defronta o comércio de troca, mas aí se esquecem de que estas dificuldades surgem do desenvolvimento do valor de troca, e, por isso, do trabalho social como trabalho geral [grifo $\mathrm{JM}$ ]. Por exemplo, as mercadorias como valores de uso não são divisíveis livremente, o que elas devem ser como valores de troca. Ou então, pode acontecer que a mercadoria de A seja valor de uso para B, mas a mercadoria de B não seja valor de uso para A; ou que os possuidores de mercadorias necessitem mutuamente de proporções desiguais de valor de suas mercadorias indivisíveis a serem trocadas mutuamente. Em outras palavras, com o pretexto de tratar do comércio de trocas diretas, os economistas fazem a idéia de alguns aspectos da contradição, que o modo de ser da mercadoria envolve como unidade imediata de valor de uso e de valor de troca. Por outro lado, prendem-se conseqüentemente ao comércio à base de troca como a forma adequada do processo de troca das mercadorias que, segundo eles, estaria vinculado apenas a certos incômodos de caráter técnico, para cuja solução o dinheiro seria um expediente habilmente inventado [Para a Crítica da Economia Política, p. 46].

$\mathrm{Na}$ argumentação convencional sobre a necessidade do dinheiro, não há nenhuma diferença entre os bens trocados numa troca com poucos participantes e numa troca com muitos participantes, generalizada; o que distingue as duas situações é a complexidade da última em contraposição à simplicidade da primeira. Ou seja: não é compreendida a especi- 
ficidade da mercadoria, que ela não é um bem qualquer, que ela só se constitui a partir de um processo social específico.

Na teoria de Marx, ao contrário, a generalização das trocas, antes de tudo, implica a transformação dos bens (produtos do trabalho) em mercadorias; isto significa acrescentarlhes, ao lado do seu valor de uso, um caráter de valor; e ao mesmo tempo atribuir ao trabalho de produzi-los, ao lado do seu caráter específico, concreto, o caráter de trabalho abstrato. Ou seja: a passagem de uma economia de trocas eventuais (em que não há ainda propriamente mercadorias) a uma economia mercantil é uma mudança profunda, qualitativa, que altera tanto o caráter dos produtos do trabalho humano (que se tornam mercadorias, e adquirem com isto uma dupla determinação), quanto o caráter do trabalho que os produz (que se torna igualmente bifacético).

A produção de mercadorias exige que cada mercadoria busque ser reconhecida como parte do trabalho social, da riqueza social geral, e isto só pode ser feito com a sua equiparação a uma mercadoria que seja a expressão geral da riqueza. Para que haja produção de mercadorias, tem de haver dinheiro, e não um simples numerário, nem um simples intermediário das trocas ${ }^{50}$.

Para apreendermos o que é o dinheiro, é preciso portanto partir da natureza dos produtos do trabalho como mercadorias, ou melhor, da natureza da economia que se organiza para a produção de mercadorias. Não é possível entender o dinheiro a partir dele mesmo, ou com um exame das suas funções: é preciso estudar as relações fundamentais da economia que o faz necessário ${ }^{51}$. Em resumo: o dinheiro não é uma mera conveniência é uma necessidade lógica, econômica e social, que decorre da própria natureza da mercadoria e do trabalho que a produz, isto é, das dualidades valor de uso - valor e trabalho concreto - trabalho abstrato.

\footnotetext{
${ }^{50}$ Isto não significa que o dinheiro deva ser uma mercadoria como o ouro, conforme foi destacado na nota 28.

${ }^{51}$ Embora reduza o dinheiro a meio de troca, Frank Hahn propõe basicamente a mesma questão: "Quais características essenciais de uma economia devem ser capturadas por um modelo, se ele deve explicar o uso, ou o uso exclusivo, de um meio particular de troca?" [Hahn 1975, p. 33]. E no mesmo sentido: "É claramente desejável estudar economias que tenham sido modeladas de uma maneira na qual os fenômenos que explicam o uso do dinheiro são intrínsecos" [Hahn 1975, p. 43].
} 


\subsection{3 - A distinção entre valor e preço}

Em um artigo cujo tema central é a especificidade da teoria econômica de Marx, Bruce Roberts faz a seguinte observação:

(...) [E]m toda a história do pensamento econômico, apenas Marx não está interessado meramente nos preços, mas em um conjunto de valores que diferem destes preços. Para Ricardo, valores-trabalho eram preços naturais, logo o interesse em um é a mesma coisa que o interesse no outro. Para os neoclássicos, valorações subjetivas refletem-se imediatamente nos preços, logo também não há um sentido separado para o valor distinto do preço. Sraffianos contemporâneos dispensaram completamente qualquer conceito de valor enquanto resolvem seus sistemas lineares de preços. Cada uma destas abordagens procura como sua solução uma 'estrutura única' de preços, um único número ligado a cada mercadoria. Apenas Marx e a tradição marxista procuram determinar teoricamente uma 'estrutura dupla' de preços, incluindo tanto o preço de uma mercadoria (ou uma forma de valor) quanto, separadamente, seu valor [Roberts 1987, p. 85].

Pode haver algum exagero nesta afirmação; a distinção clássica entre preço natural e preço de mercado é uma das maneiras de contrapor valor e preço; mesmo autores neoclássicos ocuparam-se por vezes desta questão. Mas o ponto destacado corretamente por Roberts é que na economia marxista esta distinção tem uma importância teórica qualitativamente maior da que pode ter em outras abordagens.

Roberts explica esta importância pelo objeto específico da teoria de Marx, a análise das relações de classe [Idem, p. 86]. Nesta perspectiva, deve haver uma distinção entre padrões de dispêndio de trabalho e de apropriação; é esta distinção que abre a possibilidade de transferências de tempo de trabalho.

Por exemplo, se o 'quantum pago' por uma certa mercadoria excede o 'quantum despendido' na sua produção, então o vendedor se apropria da diferença como, de fato, uma transferência de tempo de trabalho despendido em outro lugar; (...) Estes resultados são a regra mais do que a exceção (...). Em termos mais diretos, então, a distribuição capitalista dos rendimentos de lucro expressa uma transferência ou redistribuição de trabalho não pago através do mecanismo dos preços de mercado [Roberts 1987, p. 89].

Uma teoria de uma estrutura única não pode, pela própria natureza dos conceitos que usa, dar nenhum sentido sério à noção de que alguma coisa 'não é paga'. Se o único modo rele- 
vante de contar é com números que medem o que é pago, então o sentido capitalista ${ }^{52}$ da categoria fundamental para a definição de classe — a de trabalho excedente - foi simplesmente eliminado previamente [Idem, p. 90].

Esta observação é correta, no sentido de que para poder expressar uma transferência de valor na circulação é necessário dispor das categorias distintas de preço e de valor. No entanto, nos termos da economia marxista, a relação fundamental de classe - a extração direta de mais-trabalho (ou trabalho excedente) na produção, a partir do intercâmbio entre capitalista industrial e trabalhador assalariado — pode sim ser expressa independentemente desta distinção (como é bem sabido, o capitalista se apropria de uma mais valia comprando a força de trabalho por ser valor e vendendo suas mercadorias igualmente por seu valor). É a participação das demais classes proprietárias (capitalistas comerciais, capitalistas prestamistas, proprietários de terra) na distribuição da mais-valia que só pode ser explicada através da distinção entre preço e valor.

Nos Capítulos 5 e 6 voltaremos a esta questão, procurando mostrar que as vantagens analíticas da distinção entre preço e valor vão além da possibilidade de explicar a participação do conjunto das classes proprietárias na apropriação da mais-valia.

\subsection{4 - Valor, capital e dinâmica}

Finalmente, é útil ressaltar algumas peculiaridades e implicações do conceito de capital de Marx.

Marx define o capital como uma substância social - o valor - que encontra uma existência autônoma no dinheiro e se movimenta, mudando de forma, para se valorizar. $\mathrm{O}$ capital só pode ser entendido portanto como um movimento; e a idéia de que muda continuamente de forma é essencial para que possa ser compreendido. Isto naturalmente, já marca uma diferença enorme com relação às maneiras pelas quais o capital é em geral conceptualizado - na economia neoclássica, por exemplo, mas não apenas nela. Em geral, o que se faz é contrapor dois tipos de capital: capital como um estoque de bens de capital, e capital monetário ou financeiro. Para Marx, "bens de capital” e capital monetário são duas formas do capital, que só têm de fato este caráter no interior do movimento de conjunto.

\footnotetext{
52 "Sentido capitalista", por oposição ao sentido que o trabalho excedente tem em outros modos de produção, como por exemplo na corvéia.
} 
Além disso, sendo substância social, o capital só existe a partir de relações sociais historicamente específicas.

Mas o capital não é apenas movimento, mudança contínua de forma. Este movimento é um movimento autônomo: ele é uma substância semovente e um sujeito automático. É uma realidade social - formada pela reificação de relações sociais — que impõe uma marca a todo o funcionamento da economia, que faz que seu objetivo seja a acumulação de riqueza na forma geral, abstrata, de dinheiro — de dinheiro como capital.

Em todas as formas de sociedade se encontra uma produção determinada, superior a todas as demais, e cuja situação aponta sua posição e influência sobre as outras. É uma luz universal de que se embebem todas as cores, e que modifica suas particularidades ${ }^{53}$. É um éter especial, que determina o peso específico de todas as coisas emprestando relevo a seu modo de ser.

(...) O capital é a potência econômica da sociedade burguesa, que domina tudo. Deve constituir o ponto inicial e o ponto final ... [Introdução à Crítica da Economia Política, 1857, pp. 18-9].

Não é por acaso que Marx deu a seu livro fundamental o título de $O$ Capital $^{54}$.

Sendo o objetivo do capital a sua valorização, o objetivo da economia capitalista não é portanto a produção de bens para o seu posterior consumo, ou a "maximização da utilidade" trazida por este consumo. Além disto, este fato não se limita a impor uma finalidade para a produção capitalista distinta da satisfação das necessidades humanas; impõe também uma dinâmica, em que os indivíduos são subordinados ao movimento do capital. Na subseção 1.4.3 já examinamos alguns de seus aspectos; no Capítulo 5 voltaremos a esta questão. A especificidade do conceito de capital de Marx será tratada, além disso, nos Capítulos 3 e 6 .

\footnotetext{
53 A redação do texto da edição brasileira foi ligeiramente modificada, com base na edição de Siglo Veintiuno Editores [Marx 1971c], p. 27-8.

${ }^{54} \mathrm{Na}$ verdade, a história do título do livro se liga à dos diversos planos formulados por Marx para a redação de sua obra econômica. Voltaremos a isto no Capítulo 2, seção 2.2.
} 


\section{Capítulo 2 - Questões de Método}

\section{1 - INTRODUÇÃo}

Este capítulo compreende, além da Introdução, uma seção bastante longa sobre o método de $O$ Capital (a seção 2.2), e duas seções muito curtas, complementos da anterior. O maior interesse aqui é a questão da organização geral de $O$ Capital, e especialmente sua divisão em níveis de abstração nos quais se faz uma progressão do simples e abstrato ao complexo e concreto. Esta visão metodológica é muito importante para vários temas desta tese, em especial para a questão da distinção entre produção e distribuição de valor, abordada nos Capítulos 4 e 5.

A crítica ao "método das aproximações sucessivas", realizada na seção 2.3, é importante porque este método é diferente do método de Marx e, num sentido fundamental, oposto a ele; não obstante, é desta maneira que quase todos os críticos da economia de Marx o compreendem, de Böhm-Bawerk e Bortkiewicz até os mais modernos sraffianos. Além disto, esta compreensão predomina até mesmo entre os economistas marxistas.

O argumento de que Marx não tentou “provar" o valor através de uma dedução puramente lógica, apresentado na seção 2.4, esclarece um aspecto do método de $O$ Capital.

\section{2 - O MÉTODO DE O CAPITAL}

\subsection{1 — "O método da Economia Política": do abstrato ao concreto}

Em seu texto "O método da Economia Política" [Marx 1982b, pp. 14-19], que é a terceira parte da sua Introdução à Crítica da Economia Política redigida em 1857, Marx se refere à existência de dois caminhos, ou métodos ${ }^{1}$, para "[estudar] um dado país do ponto de vista da Economia Política". O primeiro, "que foi historicamente seguido pela nascente economia", começa "pelo real e pelo concreto", "pelo todo vivo"; mas os economistas que o adotaram começavam de fato por uma "representação caótica do todo", e eram depois

\footnotetext{
${ }^{1}$ Marx usa os dois termos. Na verdade, o sentido grego original da palavra "método" é justamente o de "caminho".
} 
levados a "descobrir, por meio da análise, certo número de relações gerais abstratas que são determinantes, tais como a divisão do trabalho, o dinheiro, o valor etc.”. Tendo chegado às determinações mais simples, ao cabo de uma viagem de ida, eram obrigados a fazer uma viagem de volta para retornar ao concreto, já então não mais como uma representação caótica, mas como "uma rica totalidade de determinações e relações diversas" [Introdução à Crítica da Economia Política / 1857, p. 14]².

O segundo método inicia a exposição pelo mais simples, e se apóia no trabalho dos que seguiram o primeiro:

Esses elementos isolados, uma vez mais ou menos fixados e abstraídos, dão origem aos sistemas econômicos que se elevam do simples, tal como trabalho, divisão do trabalho, necessidade, valor de troca, até o Estado, a troca entre as nações e o mercado mundial [Idem, p. 14].

Segundo Marx, este último é "manifestamente o método cientificamente exato". E agrega, para justificar esta afirmação:

O concreto é concreto porque é a síntese de muitas determinações, isto é, unidade do diverso. Por isso o concreto aparece no pensamento como o processo da síntese, como resultado, não como ponto de partida, ainda que seja o ponto de partida efetivo e, portanto, o ponto de partida também da intuição e da representação. No primeiro método, a representação plena volatiliza-se em determinações abstratas, no segundo, as determinações abstratas conduzem à reprodução do concreto por meio do pensamento. Por isso é que Hegel caiu na ilusão de conceber o real como resultado do pensamento que se sintetiza em si, se aprofunda em si, e se move por si mesmo; enquanto que o método que consiste em elevar-se do abstrato ao concreto não é senão a maneira de proceder do pensamento para se apropriar do concreto, para reproduzi-lo como concreto pensado.Mas não é de modo nenhum o processo da gênese do próprio concreto. (...)

(...) O todo, tal como aparece no cérebro, como um todo de pensamentos, é um produto do cérebro pensante que se apropria do mundo do único modo que lhe é possível, modo que difere do modo artístico, religioso e prático-mental de se apropriar dele [Introdução / 1957, pp. 14-5].

\footnotetext{
${ }^{2}$ Em seguida, este texto será referido como Introdução / 1857.
} 
A densidade deste texto recomenda um exame cuidadoso. Deixemos de lado a questão de saber se Marx resumiu corretamente a concepção de Hegel sobre a relação entre o pensamento e a realidade, que não é fundamental nesse momento ${ }^{3}$. Registremos também apenas de passagem o sentido das referências à existência de outras formas de conhecimento distintas da ciência (ou da filosofia). Marx diz que o concreto é o ponto de partida "também da intuição e da representação", e algumas linhas adiante diz que o modo de proceder do conhecimento científico difere do "modo artístico, religioso e prático mental". Nestas referências, Marx mostra uma clara influência de Hegel; segue a divisão das formas de conhecimento, de apropriação do mundo pela consciência, exposta por Hegel na última parte da sua Enciclopédia das Ciências Filosóficas (na terceira seção da terceira parte, intitulada "O Espírito Absoluto") [Hegel 1970]. Aí, o conhecimento científico é englobado pelo conhecimento filosófico, que é o conhecimento conceitual; aparece como a terceira forma de conhecimento. As outras duas, a arte e a religião, apóiam-se na intuição e na representação. Marx menciona estas outras formas de conhecimento para distingui-las do conhecimento científico, que é o seu tema.

Passando às questões que dizem respeito diretamente ao método proposto por Marx, registremos, em primeiro lugar, sua filiação inequivocamente hegeliana. Para que isto fique claro, basta comparar a afirmação "o concreto é concreto porque é a síntese de muitas determinações, isto é, unidade do diverso" com o que Hegel diz na "Pequena Lógica":

Mas o conceito enquanto é concreto - e mesmo toda determinidade em geral - é essencialmente em si mesmo uma unidade de determinações diferentes [Hegel, 1970b, pp. 296-7].

Bernard Bourgeois, tradutor e responsável pelas notas desta edição da Pequena Lógica, observa que este sentido de concreto como unidade do diverso corresponde à etimologia da palavra:

Hegel entende por concreto ("konkret"), seguindo a etimologia latina ("concrecere", crescer junto), o que é constituído por uma unidade de determinações diferentes, o resultado do processo, ele mesmo concreto, que inclui em sua identidade a diferença do movimento da

\footnotetext{
${ }^{3}$ É uma questão complexa. Mesmo alguns autores marxistas, como Tony Smith, avaliam que Marx simplificou de modo excessivo a concepção de Hegel, que não era idealista em um sentido tão direto como as frases da Introdução / 1857 citadas acima deixam entender [Smith, 1990, Capítulos I e II, pp. 3-42].
} 
diferenciação da identidade, e do movimento da identificação das diferenças [Bourgeois, Bernard, in Hegel 1970b, p. 125, nota 22].

Em segundo lugar, é preciso indicar que o contexto deixa claro que, na sua defesa deste método, Marx não está se referindo a um estudo qualquer de Economia Política, mas a uma exposição de um tipo de obra muito especial, um "tratado geral", isto é, uma obra que começa com os fundamentos e não pressupõe nenhum conhecimento anterior da matéria. Esta exposição exige um estudo anterior - uma pesquisa. No posfácio da segunda edição de $O$ Capital, lemos:

É, sem dúvida, necessário distinguir o método de exposição formalmente do método de pesquisa. A pesquisa tem de captar detalhadamente a matéria, analisar as suas várias formas de evolução e rastrear sue nexo interno. Só depois de concluído este trabalho é que se pode expor adequadamente o movimento real. Caso se consiga isto, e se chegue a espelhar idealmente a vida da matéria, talvez possa parecer ao observador estar diante de uma construção a priori [O Capital I-I, p. 26; El Capital I-I, p. 19] $]^{4}$.

Como fica claro pelas citações acima, esta pesquisa pode se estender por gerações até que seja possível começar uma exposição com o método "cientificamente exato". De fato, a pesquisa não se conclui jamais, uma vez que novas descobertas podem ser realizadas, e a exposição científica aperfeiçoada. Ernest Mandel propõe a seguinte esquematização do método defendido por Marx:

1) Assimilação pormenorizada do material empírico e domínio desse material (aparências superficiais) em todo o seu detalhe historicamente relevante.

2) Divisão analítica deste material segundo seus elementos abstratos constituintes (progressão do concreto ao abstrato).

3) Exploração das conexões gerais decisivas entre esses elementos, que explicam as leis abstratas de movimento do material — a sua essência, em outras palavras.

4) Descoberta dos elos intermediários fundamentais, que efetuam a mediação entre a essência e a aparência superficial da matéria (progressão do abstrato ao concreto, ou a reprodução do concreto pensado como uma combinação de múltiplas determinações).

5) Verificação empírica prática da análise $(2,3,4)$ no movimento em curso da história concreta.

\footnotetext{
${ }^{4}$ A redação da edição Nova Cultural foi modificada ligeiramente, em benefício da clareza.
} 
6) Descoberta de dados novos, empiricamente relevantes, e de novas conexões - muitas vezes até mesmo de novas determinações elementares abstratas —, mediante a aplicação dos resultados do conhecimento, e da prática neles baseada, à infinita complexidade do real [Mandel 1985, pp. 9-10].

$\mathrm{Na}$ verdade, Mandel se concentrou nesta esquematização no método de pesquisa e nas suas conexões com o método de exposição, deixando num segundo plano as questões da exposição propriamente dita $^{5}$. Com relação ao método de exposição, podemos identificar os seguintes elementos nas passagens citadas de Marx:

1) Toda exposição científica é uma "maneira de proceder do pensamento para se apropriar do concreto, para reproduzi-lo como concreto pensado". Neste sentido, o concreto é seu "ponto de partida efetivo", embora a exposição não comece por ele.

2) O concreto "aparece no pensamento como o processo da síntese, como resultado", uma vez que ele "é concreto porque é a síntese de muitas determinações, isto é, unidade do diverso". Neste contexto, o concreto é complexo.

3) A exposição deve começar com "determinações as mais simples", com "as determinações abstratas". No contexto do método proposto por Marx, simples e abstrato são praticamente sinônimos. Neste sentido, abstrato e concreto são termos relativos: mais simples, menos determinações - mais abstrato; mais complexo, mais determinações - mais concreto.

4) Após o começo pelo simples e abstrato, a exposição deve realizar um processo de síntese, acrescentar progressivamente novas "determinações". Chegará por esta via ao todo, ao concreto, "mas desta vez não com uma representação caótica de um todo, porém como uma rica totalidade de determinações e relações diversas" [Introdução / 1957, p. 14].

\footnotetext{
${ }^{5}$ Uma variante da mesma posição - mas que, de nenhuma maneira, coloca em segundo plano o método de exposição - é expressa por Tony Smith. Ele menciona um ponto de partida que é a experiência imediata num contexto histórico particular; depois um "estágio de apropriação" e um "estágio de reconstrução", correspondentes, naturalmente, à pesquisa e à exposição [Smith 1990, pp. 4-6 e 33-35].
} 
5) Este método é chamado de "o método que consiste em elevar-se do abstrato ao concreto".

No texto sobre "O método da Economia Política", Marx não explicita de modo completamente claro quais seriam as "determinações mais simples" das quais a exposição deveria partir. Na verdade, podemos até afirmar que toca no tema de modo um tanto incoerente. De um lado, sua discussão da ordem das categorias conclui dizendo que:

(...) O capital é a potência econômica da sociedade burguesa, que domina tudo. Deve constituir o ponto inicial e o ponto final e ser desenvolvido antes da propriedade da terra ${ }^{6}$. Depois de considerar particularmente um e outro, deve-se estudar sua relação recíproca.

Seria, pois, impraticável e errôneo colocar as categorias econômicas na ordem segundo a qual tiveram historicamente uma ação dominante. A ordem em que se sucedem se acha determinada, ao contrário, pelo relacionamento que têm umas com as outras na sociedade burguesa moderna, e que é precisamente o inverso do que parece ser uma relação natural, ou do que corresponde à série do desenvolvimento histórico. (...) Trata-se da sua hierarquia no interior da moderna sociedade burguesa [Introdução / 1957, pp. 18-9].

Por outro lado, no final do texto, Marx enumera uma ordenação das "seções" que deveriam ser adotadas na sua obra econômica (que ele viria a chamar de Crítica da Economia Política). Esta enumeração segue claramente uma progressão abstrato $\rightarrow$ concreto, ou simples $\rightarrow$ complexo; podemos identificar aí níveis de abstração, etapas da exposição teórica que se distinguem umas das outras pelo grau de abstração (ou de concreticidade) e de simplicidade (ou de complexidade) em que se colocam, começando pelo nível mais simples e abstrato e terminando com o mais complexo e concreto. Isto está de acordo, sem dúvida, com a concepção exposta sobre o método de exposição; mas não começa pelo capital.

A primeira "seção" trataria do seguinte:

1 - as determinações abstratas gerais, que convêm portanto mais ou menos a todas as formas de sociedade, mas consideradas no sentido acima discutido [Idem, p. 19].

\footnotetext{
${ }^{6}$ Nos parágrafos anteriores, Marx havia discutido a hipótese de começar a exposição pela propriedade da terra. A parte inicial desta frase foi citada no Capítulo 1, na subseção 1.5.4, para destacar que, na economia capitalista, o capital impõe sua marca a todas as relações econômicas.
} 
Por "determinações abstratas gerais" Marx certamente entende aqui a discussão geral da produção, do consumo, da distribuição e da troca, feita nas duas primeiras partes da própria Introdução à Crítica da Economia Política.

É só a segunda "seção" que se refere ao capital. Seu conteúdo é indicado da seguinte maneira:

2 - as categorias que constituem a articulação interna da sociedade burguesa e sobre as quais assentam as classes fundamentais. Capital, trabalho assalariado, propriedade fundiária. Os seus relacionamentos recíprocos. Cidade e campo. As três grandes classes sociais. A troca entre estas. A circulação. O sistema de crédito (privado) [Idem, p. 19].

Ou seja, é esta segunda "seção" que começa pelo capital.

No entanto, nem Para a Crítica da Economia Política, publicada dois anos depois da redação da Introdução /1857, nem O Capital, começam pela primeira "seção" indicada; começam pela análise da mercadoria (que não havia sido mencionada - explicitamente ${ }^{7}$, ao menos - como começo nem na segunda "seção"). Tampouco o plano geral destas obras corresponde à enumeração mencionada acima.

As referências feitas por Marx ao método seguido em $O$ Capital, no seu último escrito sobre economia, as Notas Marginais ao Tratado de Economia Política de Adolph Wagner $^{8}$, também parecem indicar uma concepção diferente da enunciada na Introdução / 1857. Nestas notas, ao polemizar com a concepção de Wagner de que um tratado de economia deve partir da análise de conceitos (que Wagner atribuíra também a ele próprio), Marx chama a atenção para o caráter concreto do ponto de partida de sua exposição.

Segundo o senhor Wagner, valor de uso e valor de troca devem derivar-se d'abord do conceito de valor, e não como eu faço, de um concretum das mercadorias (...) [Notas sobre Wagner, p. 39].

Algumas páginas depois, Marx reforçou este argumento:

De prime abord, eu não parto de "conceitos", e portanto tampouco do "conceito de valor", razão pela qual não tenho por que dividir de modo algum este "conceito". De onde parto, é

\footnotetext{
${ }^{7}$ Como veremos adiante, começar pela mercadoria é, de fato, começar pelo capital.

${ }^{8}$ A partir daqui citadas como Notas sobre Wagner. As referências das páginas são da edição em espanhol das Ediciones Pasado y Presente.
} 
da forma social mais simples em que toma corpo o produto do trabalho na sociedade atual, que é a "mercadoria". (...) Como se vê, não divido o valor em valor de uso e valor de troca, como termos antitéticos em que se decomponha a abstração "valor", senão digo que a forma social concreta do produto do trabalho, a "mercadoria", é de um lado valor de uso e de outro "valor", não valor de troca, pois este é uma simples forma de aparecer e não seu próprio conteúdo [Idem, pp. 48-9].

E um pouco mais adiante:

(...) $[\mathrm{N}]$ osso vir obscurus (...) nem sequer se deu conta de que meu método analítico, que não parte do homem, mas de um período social economicamente dado, não guarda nem a mais remota relação com esse método de entrelaçamento de conceitos que gostam de empregar os professores alemães (...) [Idem, p. 51].

Segundo Marx, portanto, a exposição começa por uma forma social concreta ${ }^{9}$. Além disso, a ênfase em que parte de "um período social economicamente dado" contrasta claramente com o conteúdo da primeira "seção", apontada na Introdução / 1857 como início de sua obra econômica.

Temos, portanto, razões suficientes para colocar a questão: qual a relação entre o texto sobre o "método da Economia Política" e a obra posterior? O método de "elevar-se do abstrato ao concreto", que é o tema central do texto de 1857, corresponde ao seguido por Marx na redação posterior de sua obra? Ou é outro o método de $O$ Capital?

Antes de tentar responder a estas perguntas, é preciso examinar de uma forma mais ampla o significado do começo de $O$ Capital. Ou seja, procurar avaliar qual é o objeto da Seção I do Livro I, e qual é o lugar que ocupa no conjunto da obra. Isto nos levará, como veremos, ao tema da relação entre essência e aparência, de modo que também esta questão terá de ser brevemente examinada. Em seguida, será necessário ainda avaliar as implicações das mudanças no plano geral da obra econômica de Marx até $O$ Capital. Só depois estaremos em condições de retomar as perguntas do parágrafo anterior.

\subsection{2 - A Seção I}

\footnotetext{
${ }^{9}$ O sentido de concreto , aqui, parece ser o de "historicamente determinado".
} 
Na Seção I do Livro I de $O$ Capital, Marx parte da mercadoria, como unidade de valor de uso e valor; da análise da forma do valor chega ao dinheiro; e as funções do dinheiro são analisadas. Só na seção seguinte o capital será definido.

Em seu artigo "A lei do valor e a taxa de lucro", escrito em 1895 para figurar como apêndice ao Livro III de $O$ Capital [Engels 1976], Engels propôs uma interpretação para o significado desta seção e para seu lugar no livro que, como seria de se esperar, teve grande influência: Marx aí não estaria ainda tratando da economia capitalista, mas sim de uma "produção mercantil simples"10. Este tipo de sociedade teria existido "desde o começo do intercâmbio que transforma os produtos em mercadorias até o século XV de nossa era", um lapso de tempo que pode ser calculado como tendo entre "cinco e sete milênios" [Engels 1976, p. 1137]. A lei do valor, entendida como a venda das mercadorias por preços que oscilam em torno de seus valores ${ }^{11}$, teria então vigência plena e direta. Já na economia capitalista, ela ainda tem vigência, mas de uma forma modificada, já que os preços (de mercado) das mercadorias passaram a oscilar em torno dos preços de produção ${ }^{12}$.

Esta posição de Engels é vulnerável por várias razões. Destas, talvez a que chame a atenção mais rapidamente seja o caráter duvidoso de sua descrição histórica. Embora se possa dizer que houve algum tipo de comércio e, neste sentido, de produção de mercadorias por milhares de anos, em nenhuma sociedade antes da economia capitalista esta forma de produção foi predominante; a maior parte da produção era destinada ao consumo dos produtores ou de senhores, e não passava por nenhum tipo de mercado. Ainda que fosse possível chamar a parte que se destinava ao comércio de "produção mercantil simples" e dizer que os produtos se trocavam na proporção do tempo de trabalho necessário à sua

\footnotetext{
${ }^{10}$ Christopher Arthur [1996] dá numerosas indicações, inclusive, de como muitos autores se referiram a este texto de Engels como se fosse do próprio Marx.

${ }^{11}$ Como vimos no Capítulo 1, e veremos de modo mais completo no Capítulo 5, a "lei do valor" é bem mais complexa do que isto.

${ }^{12} \mathrm{O}$ objetivo do artigo de Engels era defender a teoria do valor de Marx da crítica de que ela não teria validade prática, já que, no capitalismo, como o próprio Marx havia reconhecido, as mercadorias se vendem na média segundo seus preços de produção. A questão da relação entre valores e preços de produção será abordada no Capítulo 4, e a do significado da lei do valor, no Capítulo 5. Tratamos aqui apenas da afirmação de que a Seção I do Livro I se refere a uma "produção mercantil simples”, distinta da economia capitalista.
} 
produção $^{13}$, a vantagem disto seria muito reduzida: não daria à lei do valor assim entendida mais que um estatuto muito parcial e subordinado.

Por esta razão Ronald Meek, no apêndice sobre o "método econômico de Karl Marx" que conclui seus Studies in the Labour Theory of Value [Meek 1973, pp. 299-318], modificou em parte o argumento de Engels. Justificando o emprego do que ele chama (seguindo Engels também neste ponto) de “abordagem lógico-histórica”, ele diz o seguinte, em uma passagem que merece ser citada por extenso:

(...) [S]e alguém desejava analisar o capitalismo em termos de relações de produção, a melhor maneira de fazê-lo era imaginar o capitalismo subitamente se impondo sobre uma espécie de sociedade pré-capitalista generalizada, na qual não há ainda classes proprietárias de capital e da terra separadas. O que alguém deveria fazer, em outras palavras, seria começar postulando uma sociedade na qual, embora se assumisse que a livre concorrência e a produção de mercadorias reinavam mais ou menos supremas, os trabalhadores ainda seriam proprietários de todo o produto do seu trabalho. Tendo investigado as leis que governam a produção, a troca e a distribuição em uma sociedade deste tipo, seria preciso então imaginar o capitalismo subitamente se impondo sobre esta sociedade. Qual diferença esta imposição faria para as leis econômicas que operavam antes da mudança, e por que? Se alguém puder dar respostas adequadas a estas questões, Marx acreditava, estaria na rota de revelar a essência real do modo capitalista de produção. Adotando este tipo de abordagem, Marx estava, naturalmente, seguindo - e desenvolvendo - uma longa e respeitável tradição que tinha sido estabelecida por Smith e Ricardo. A postulação por Marx de uma sociedade précapitalista baseada no que ele ${ }^{14}$ chamou de produção mercantil "simples" não era essencialmente diferente nos seus objetivos da postulação por Adam Smith de uma sociedade "antiga e rude" habitada por caçadores de cervos e castores. Nem no caso de Marx nem no de Smith a sociedade pré-capitalista postulada pretendia ser uma representação acurada da realidade histórica em algo além de um sentido muito amplo. Nem pretendia ser o retrato de uma forma de sociedade ideal, uma espécie de idade do ouro do passado que a vinda dos capitalistas e proprietários de terra maldosos estava destinada rudemente a destruir. Era claramente parte de um artifício analítico muito complexo, e a seu tempo muito

\footnotetext{
${ }^{13}$ Como veremos em seguida, tampouco esta afirmação se sustenta.

${ }^{14}$ Na verdade, a designação "produção mercantil simples” não foi de Marx, mas de Engels. O termo só aparece uma vez em O Capital, no Livro III, em uma passagem acrescentada por Engels. Cf. Arthur 1998, p. 15, nota 10 .
} 
poderoso. Costumo dizer a meus estudantes que não se tratava de um mito, mas antes de mitodologia [Meek 1973, pp. 303-4].

Não há dúvida de que o artifício analítico "mitodológico" descrito — essencialmente, o de comparar o funcionamento da economia capitalista com um modelo construído de sociedade mercantil pré-capitalista - é coerente, e pode eventualmente ser aplicado com proveito, sobretudo se o objetivo for chamar a atenção para as diferenças entre as leis do capitalismo e as deste modelo de sociedade. Este era certamente o caso de Adam Smith, que argumentou justamente que, após o desenvolvimento da propriedade privada do "capital" e da terra, o valor das mercadorias não pode ser proporcional às quantidades de trabalho requeridas para a sua produção.

Mas não é possível defender que o mesmo se aplica a Marx. O tema central do Livro I, por exemplo, é a análise das relações gerais entre capital e trabalho no processo de produção; apóia-se de forma decisiva no conceito de mais-valia ${ }^{15}$. Ora, a teoria do valor exposta na primeira seção é imprescindível para que o conceito de mais-valia faça sentido! Uma modificação na concepção do valor semelhante à proposta por Adam Smith tiraria todo o sentido deste conceito, que depende diretamente da idéia de que os valores das mercadorias são proporcionais às quantidades de trabalho (abstrato) necessárias à sua produção ${ }^{16}$. Para a construção teórica que Marx faz em $O$ Capital, pouco adianta dizer que a lei do valor teve plena vigência por mais de cinco mil anos antes do capitalismo; o que é necessário é mostrar como esta lei tem vigência na economia capitalista. Assim, tentativas de defender a teoria do valor, tal como as feitas por Engels e por Meek, na verdade não defendem os aspectos fundamentais da teoria econômica de $\operatorname{Marx}^{17}$.

\footnotetext{
${ }^{15}$ Autores sraffianos, como Pierangelo Garegnani, têm afirmado que a existência da exploração na economia capitalista pode ser justificada sem os conceitos de valor e mais-valia [Garegnani 1979]. Mas de fato ao fazêlo reduzem a exploração à oposição entre lucros e salários na distribuição, o que fica muito aquém do conceito marxista de exploração. Para este, e para fundamentar a partir daí toda a compreensão da relação capital — trabalho, o conceito de mais-valia é indispensável.

${ }^{16}$ Mas o conceito de mais-valia não perde sua coerência quando agregamos que o preço pode desviar-se do valor, realizando assim uma transferência de valor na circulação, tal como analisamos na subseção 1.3.1 do Capítulo 1. Voltaremos a esta questão nos Capítulo 4 e 5.

${ }^{17}$ Há ainda uma outra versão da idéia de que a Seção I do Livro I não trata ainda propriamente do capitalismo (que aliás é perfeitamente compatível com a posição de Meek). É a concepção de que Marx seguiria o "mé-
} 
As interpretações de Engels e de Meek para o significado da Seção I do Livro I não cumprem, portanto, seu objetivo. Isto, contudo, não implica obrigatoriamente que a idéia de que esta seção não trata ainda da economia capitalista seja incorreta. É a questão do significado desta seção, pois, que é necessário examinar agora.

Um argumento bastante óbvio é o de fazer referência a como o próprio Marx pensava a respeito. Neste aspecto, parece não haver dúvidas. A frase com que ele começou $O$ Capital explica que a investigação começa com a análise da mercadoria enquanto "forma elementar" da "riqueza das sociedades em que domina o modo de produção capitalista" [ $O$ Capital I-I, p. 45]. Nas Notas sobre Wagner, ele retomou a mesma idéia, como vemos na frase já citada anteriormente:

De onde parto, é da forma social mais simples em que toma corpo o produto do trabalho na sociedade atual, que é a "mercadoria” [p. 48].

Naturalmente, a "sociedade atual" de que fala só pode ser a sociedade capitalista.

A posição do próprio Marx, contudo, é em si mesma insuficiente para fundamentar uma conclusão. É possível pensar, como vários críticos o fazem, que ele foi inconsistente.

Dos autores que já abordaram este problema, muitos divergiram de Engels e Meek, isto é, concluíram que Marx fez de fato aquilo a que se propusera, que a Seção I do Livro I de $O$ Capital trata realmente da economia capitalista. O primeiro a defender esta posição foi, provavelmente, Isaac Rubin, desde os anos 20 do século XX [Rubin, 1980] - mas sua obra só passou a ser bem conhecida quando foi publicada em inglês, em 1972. Outro pioneiro foi Roman Rosdolsky [Rosdolsky, 2001], cuja obra fundamental foi publicada em 1968. Desde então, o número dos que criticam a interpretação de Engels aumentou muito ${ }^{18}$.

Rubin e Rosdolsky, apoiando-se na concepção de que Marx segue em $O$ Capital o método de "elevar-se do abstrato ao concreto", argumentaram que a Seção I representa um

todo das aproximações sucessivas", da qual Maurice Dobb e Paul Sweezy são os principais proponentes. Deixaremos o comentário desta posição para a seção 2.3 .

${ }^{18}$ Ruy Fausto, num trabalho publicado inicialmente em 1978, diz com certo exagero: "Esta resposta de Engels é criticada hoje quase unanimemente" [Fausto, 1983c]. A contribuição de Ruy Fausto para a compreensão desta questão será comentada mais adiante. 
nível mais abstrato da reprodução teórica da própria economia capitalista. É um argumento importante, que será retomado adiante.

Outro argumento, mais direto, está também presente nos dois autores citados: o de que o desenvolvimento da economia capitalista é necessário para que as categorias expostas na Seção I possam existir plenamente; ao contrário de uma das bases do argumento de Engels, os produtos do trabalho não podem se constituir plenamente como mercadorias e desenvolver seu aspecto de valores em uma "economia mercantil pré-capitalista". O próprio Marx, em "O método da Economia Política", vinculou a categoria de trabalho abstrato ao capitalismo desenvolvido.

(...) [E]ssa abstração do trabalho em geral não é apenas o resultado intelectual de uma totalidade concreta de trabalhos. A indiferença em relação ao trabalho determinado corresponde a uma forma de sociedade na qual os indivíduos podem passar com facilidade de um trabalho a outro e na qual o gênero determinado de trabalho é fortuito e, portanto, é-lhes indiferente. Nesse caso, o trabalho se converteu não só como categoria, mas na efetividade, em um meio de produzir riqueza em geral, deixando, como determinação, de se confundir com o indivíduo na sua particularidade. Esse estado de coisas se encontra mais desenvolvido na forma de existência mais moderna da sociedade burguesa - nos Estados Unidos. Aí, pois, a abstração da categoria "trabalho", "trabalho em geral", trabalho sans phrase, ponto de partida da Economia moderna, torna-se pela primeira vez praticamente verdadeira [Introdução à Crítica da Economia Política / 1857, p.17].

E de novo, relacionando o trabalho abstrato ${ }^{19}$ com a categoria de valor:

Naturalmente, Steuart sabia muito bem que o produto também em épocas pré-burguesas assume a forma de mercadoria, e esta a forma do dinheiro, mas demonstra detalhadamente que a mercadoria, como forma básica elementar da riqueza, e a alienação, como forma predominante da apropriação, pertencem apenas ao período burguês de produção, e que o caráter do trabalho que põe valor de troca é, por conseguinte, especificamente burguês [Para a Crítica da Economia Política, p. 51].

Há um outro argumento que vincula a plena existência do valor ao desenvolvimento do capitalismo. Como vimos no Capítulo 1, na subseção 1.2.4, a comparação das mercadorias como valores com um equivalente geral, com o dinheiro, é um elemento cen-

\footnotetext{
${ }^{19} \mathrm{O}$ "trabalho que põe o valor de troca" é, naturalmente, o trabalho abstrato.
} 
tral da conclusão do processo que transforma os produtos de trabalho em mercadorias, duplica o caráter do trabalho e constitui o dinheiro. Ora, este elemento de comparação é fundamental também para fixar os valores quantitativamente, e portanto para estabelecer o tempo de trabalho (abstrato) socialmente necessário para a produção de cada mercadoria. O socialmente necessário é uma norma social objetiva, coercitiva, que se impõe aos produtores. Mas esta norma só tem de fato este caráter se todos os insumos, inclusive a força de trabalho, precisam ser comprados, e a concorrência entre os capitais tem plena vigência. Como diz Christopher Arthur:

De acordo com Marx, a lei do valor se baseia na troca de acordo com os tempos de trabalho socialmente necessários ${ }^{20}$, mas no caso da produção mercantil simples não há mecanismo que force um dado produtor a obedecer esta norma ou ser posto para fora do negócio. Quando todos os insumos, inclusive a própria força de trabalho, têm uma forma de valor e a produção é subordinada à valorização, então uma comparação objetiva de taxas de retorno sobre o capital é possível e a concorrência entre capitais permite a imposição da lei do valor [Arthur 1998, pp. 6-7].

Arthur desenvolve esta argumentação mais longamente em um artigo de 1996 [Arthur 1996, pp. 188-193]; aí, cita uma passagem de Para a Crítica da Economia Política em que Marx se refere a esta questão:

Em oposição a Adam Smith, David Ricardo salienta a determinação do valor da mercadoria pelo tempo de trabalho, e mostra que essa lei domina também as relações burguesas de produção, que aparentemente mais a contradizem. As investigações de Ricardo limitam-se exclusivamente à grandeza de valor, com relação à qual ele ao menos suspeita que a realização da lei depende de pressupostos históricos determinados. Diz que a determinação da grandeza de valor, através do tempo de trabalho, vale somente para as mercadorias, "que podem ser multiplicadas pela indústria e cuja produção é regida por uma concorrência ilimitada". De fato isso quer dizer apenas que a lei do valor para seu pleno desenvolvimento pressupõe a sociedade da grande produção industrial e da livre concorrência, isto é, a sociedade burguesa moderna [Para a Crítica da Economia Política, p. 52; comentário de Arthur em Arthur 1996, p. 191-3].

\footnotetext{
${ }^{20}$ Como já mencionamos antes, e trataremos de modo mais completo no Capítulo 5, a "lei do valor" é bastante mais complexa do que isto.
} 
O mesmo ponto é desenvolvido por John Weeks [Weeks 1981, pp. 29-40] ${ }^{21}$.

Ou seja: antes do capitalismo, o valor das mercadorias só pode existir como uma aproximação, como uma realidade em formação, ainda não completamente desenvolvida; como diz Ruy Fausto, como uma realidade contraditória.

O valor antes do capitalismo tem um estatuto análogo ao de um ser qualquer no nível da sua pré-história. No nível da sua pré-história, um ser não existe enquanto sujeito; uma préhistória é exatamente a história de seu surgimento enquanto sujeito. Existem entretanto, no nível da pré-história, certas determinações que exprimem mas que ao mesmo tempo não exprimem esse ser, isto é, existem certas determinações que exprimem esse ser (ausente enquanto sujeito) em forma negativa, em forma contraditória [Fausto, 1983c, p. 113].

Portanto, a Seção I do Livro I de O Capital não trata de algum tipo de sociedade anterior ao modo de produção capitalista, quer referindo-se a alguma sociedade que tenha existido historicamente de fato, quer como um expediente lógico: trata da própria economia capitalista. Esta conclusão, porém, traz com ela alguns problemas. Como podemos afirmar que a Seção I trata da economia capitalista, se nela não aparecem nem o capital, nem o trabalho assalariado? E se nela, além disto, a finalidade do movimento é o consumo de valores de uso, e não a valorização do capital ${ }^{22}$

A resposta de Rubin e Rosdolsky, que acreditam que Marx segue em $O$ Capital o método de "elevar-se do abstrato ao concreto" é, como vimos, que a Seção I representa um nível mais abstrato da reprodução teórica da própria economia capitalista. A análise da

\footnotetext{
${ }^{21}$ Em sua crítica à teoria do valor de Marx, Castoriadis lança mão do mesmo argumento, embora de uma forma menos precisa. Fala da necessidade, para que a "lei do valor-trabalho" e o cálculo do tempo de trabalho socialmente necessário possam se aplicar, de um grau de concorrência entre os produtores que só poderia existir no capitalismo "e mediante os mais delirantes postulados da economia burguesa neoclássica". Menciona como exemplos destes postulados a necessidade de "mobilidade perfeita e instantânea dos capitais e dos operários", além de outras condições [Castoriadis 1987, pp. 274-5]. O exagero de, como condições da lei do valor, incluir a necessidade dos postulados delirantes da economia neoclássica se explica porque Castoriadis afirma que a existência do trabalho socialmente necessário estaria ligada a que os tempos efetivos de trabalho fossem "em qualquer período, para todos os ramos, efetivamente reconduzidos, na grande maioria dos casos, aos tempos médios" [Idem, p. 274]. Esta exigência, contudo, não é de nenhuma maneira necessária.

${ }^{22}$ Ruy Fausto expôs estes problemas de forma clara: Fausto 1983d, pp. 181-2 e Fausto 1997, pp. 25-7.
} 
mercadoria e da sua circulação (a circulação simples) seria um passo prévio necessário, que prepararia a inclusão posterior do capital e do trabalho assalariado.

Esta resposta ainda deixa, contudo, um problema: na medida em que na circulação simples de mercadorias a finalidade do processo é o consumo de valores de uso, não se trata apenas de que faltam determinações essenciais ao capitalismo; este é, além disto, negado. Como destaca Ruy Fausto, esta questão se apresenta como uma antinomia: há razões para afirmar que a tese - a Seção I trata do capital (como vimos acima), mas há igualmente razões para afirmar a antítese — o capital está ausente da Seção I [Fausto, 1983d, p. 182; Fausto, 1997, pp. 25-6]. Fausto mostra também como resolvê-la: a antinomia pode ser superada quando compreendemos que "a Seção I do livro I de $O$ Capital tem por objeto a aparência do modo de produção capitalista" [Fausto, 1983d, p. 181; cf. igualmente Fausto, 1997, p. 26]. Ele explica por que:

A solução da antinomia está na redução da tese e da antítese a "momentos" em sentido dialético rigoroso: "momento" como equivalente do "ser-suprimido" (aufgehobensein).

A resposta [à questão: a Seção I trata do capitalismo? - JM] é sim e não, ou antes simnão: trata-se do capitalismo (tese), mas na forma — que é dele entretanto — do não capitalismo (antítese) [Fausto, 1997, p. 26].

(...) [A] passagem da antinomia à contradição dialética se opera através da noção de aparência, como (auto) negação da essência (...) [Fausto, 1997, p. 27].

A aparência que nega a existência do capitalismo é, portanto, um momento do próprio capitalismo. O capitalismo é um sistema que oculta suas relações essenciais, e se apresenta como circulação simples, como pura troca de mercadorias tendo em vista o valor de uso.

A relação entre circulação simples e aparência já havia sido apontada pelo próprio Marx. Nos Grundrisse, ele escreveu que a circulação simples “[é] o fenômeno de um processo que ocorre por detrás dela" [Grundrisse, I, p. 194]. No mesmo sentido, na primeira versão de Para a Crítica da Economia Política, podemos ler a seguinte passagem:

A circulação simples é, mais que nada, uma esfera abstrata do processo de produção burguês em seu conjunto, uma esfera que em virtude de suas próprias determinações se acredita como momento, mera forma de manifestação de um processo mais profundo situado detrás dela, que deriva dela e que por sua vez a produz: o capital industrial [Grundrisse, III, p. 188]. 
A idéia da circulação simples como aparência do processo mais profundo, que é o movimento do capital, está portanto claramente apoiada no texto do próprio Marx.

A citação anterior também diz que a circulação simples constitui uma esfera abstrata do processo de produção capitalista. Abstrata porque muitas determinações da economia capitalista não estão presentes. Assim, não está presente nenhuma das características da economia capitalista que se desenvolvem a partir da relação capital — trabalho; o caráter antagônico das relações capitalistas é abstraído, do mesmo modo que a exploração dos trabalhadores. Aliás, não há na Seção I trabalhadores, no sentido que esta palavra tem para Marx, de trabalhadores assalariados, nem proprietários de capital (não há capital). Há apenas agentes que produzem e trocam mercadorias. A natureza profunda, essencial, do antagonismo, da exploração capitalista é oculta; o que aparece é uma economia de trocas, a circulação simples de mercadorias ${ }^{23}$; esta aparência decorre da própria natureza da economia capitalista.

A idéia de que a Seção I trata da aparência do modo de produção capitalista tem portanto ampla fundamentação.

Permanecem ainda, no entanto, alguns problemas.

Em primeiro lugar, é certamente impossível dizer que a Seção I trata apenas da aparência da produção capitalista. Valor e, mais ainda, trabalho abstrato, além de serem categorias que só se desenvolvem completamente no capitalismo, são também categorias que de nenhuma maneira podem ser classificadas como pertencendo à aparência. Também $a$ mercadoria, como observa Moishe Postone, é uma das categorias que constituem "a estrutura profunda da sociedade capitalista" [Postone 1993, p. 135], embora seja igualmente uma categoria que aparece ${ }^{24}$.

\footnotetext{
${ }^{23}$ Mesmo quando a força de trabalho se transforma em mercadoria, a exploração não aparece no nível da circulação; a força de trabalho aparece como mais uma mercadoria que se troca por seu valor.

${ }^{24}$ Ponto que é explicitado por Marx desde a primeira frase do Capítulo I do Livro I. Mas quando aparece na circulação simples, a mercadoria só o faz parcialmente; fica oculto, por exemplo, o fato de que, como categoria da economia capitalista, ela é um produto do capital.
} 
Ruy Fausto notou este problema, já no seu trabalho de $1983^{25}$, e esclareceu que a Seção I não trata apenas da aparência do modo de produção capitalista, mas desta aparência e do seu fundamento.

A circulação simples é a aparência do modo de produção capitalista: isto significa que, considerado num nível puramente fenomenal, o sistema nos revela um conjunto de intercâmbios que tomados em si mesmos se apresentam como simples intercâmbios de mercadorias. Mas o problema é difícil porque a circulação simples não trata só da aparência, entendida como circulação simples. A análise da seção I tem como objeto não só o intercâmbio de mercadorias, ela se interroga, e sobretudo, sobre os fundamentos desse intercâmbio. Temos assim a aparência e o fundamento dessa aparência [Fausto 1983d, p. 183].

Em um texto posterior, publicado em $1997^{26}$, Ruy Fausto retomou a idéia de que na Seção I está presente também o fundamento da aparência, e retrabalhou toda a discussão, "dando especial atenção às relações entre aparência e fundamento" [Fausto 1997, p. 28; a discussão da relação entre aparência e fundamento na Seção I de $O$ Capital é tratada nas pp. 24-32].

A afirmação de que a Seção I trata do fundamento da aparência (da circulação simples) pode ser entendida, em dois sentidos: fundamento da aparência no sentido de explicação, de por que as relações capitalistas aparecem assim; e fundamento da aparência no sentido da essência que lhe corresponde. Os dois sentidos estão presentes na Seção I. O primeiro liga-se a questões como a do fetichismo da mercadoria, e o segundo à presença de categorias essenciais como valor e trabalho abstrato. Mas se aceitamos este segundo sentido, especialmente se dizemos que a análise na Seção I "se interroga, e sobretudo, sobre os fundamentos desse intercâmbio", já não é possível dizer propriamente que "a Seção I trata da aparência do modo de produção capitalista"27.

\footnotetext{
${ }^{25}$ Redigido em 1981, cf. Fausto 1983a, p. 15, nota.

${ }^{26}$ Dialética Marxista, Dialética Hegeliana: A Produção Capitalista como Circulação Simples.

${ }^{27}$ Ruy Fausto argumenta, para justificar a razão de privilegiar a aparência na sua caracterização da Seção I: "Entretanto, os fundamentos são introduzidos aqui só como fundamentos dessa aparência. Não que eles desaparecerão quando se passar à teoria do capital, mas eles sofrerão uma operação fundamental" [Fausto 1983d, p. 183]. Esse argumento, contudo — retomado e ampliado no texto de 1997 — não é completamente convincente.
} 
Há ainda outro problema na caracterização da Seção I: Marx trata da aparência do modo de produção capitalista ao longo de todo O Capital, e em especial no Livro III (como ele próprio anuncia no parágrafo introdutório do Capítulo I deste livro ${ }^{28}$ ). Neste livro, o tratamento da aparência é especialmente destacado na última Seção (a VII) "Os Rendimentos e Suas Fontes”. Dentro desta Seção, o Capítulo XLVIII, “A Fórmula Trinitária”, é uma crítica à economia vulgar que, segundo Marx, rumina aparências; e o Capítulo L, "A Ilusão da Concorrência" - ou "A Aparência da Concorrência", dependendo da tradução - trata justamente de como, na concorrência, as coisas aparecem invertidas. A Seção I do Livro I trata de uma parte importante da aparência da economia capitalista - mas de uma parte apenas.

Para resumir as dificuldades com a interpretação de que "a Seção I do livro I de $O$ Capital tem por objeto a aparência do modo de produção capitalista": esta seção não trata apenas da aparência do modo de produção capitalista; trata também de aspectos da sua essência. E nem todo o tratamento da aparência do modo de produção capitalista é feito na Seção I: ela se estende ao longo de todo $O$ Capital, sendo que uma parte decisiva é feita no Livro III, sobretudo na sua última seção.

Estas dificuldades não anulam a importância de ressaltar o lugar central que a aparência tem na Seção I. Isto permite explicar por que, embora o objeto desta seção seja já a economia capitalista, as relações capitalistas não aparecem ainda explicitamente ${ }^{29}$ e, mais do que isto, são negadas pela posição do valor de uso como finalidade do movimento.

Há uma última questão, decisiva para o entendimento do lugar que a Seção I do Livro I ocupa em $O$ Capital. Por que Marx começou sua exposição por aí, privilegiando a aparência, e chegando a fundamentos da economia capitalista a partir da análise da sua aparência? Retomaremos esta questão adiante, na subseção 2.2.5.

\footnotetext{
28 “As configurações do capital, como as desenvolvemos neste livro, aproximam-se, portanto, passo a passo, da forma em que elas mesmas aparecem na superfície da sociedade, na ação dos diferentes capitais entre si, na concorrência e na consciência costumeira dos agentes da produção” [O Capital III-IV, p. 21].

${ }^{29}$ As relações capitalistas estão presentes — são pressupostas — já que sem elas não poderia haver trabalho abstrato e valor, como vimos. Ruy Fausto enfatiza este ponto: “(...) a ausência do capital na Seção I não é uma ausência pura e simples, mas uma ausência-presença, e quando se diz que a finalidade não é o valor, esse ‘não’ é também outra coisa que não uma simples negação” [Fausto 1997, p. 26].
} 
Antes, é preciso abordar brevemente a questão de como as relações entre essência e aparência se colocam no conjunto de $O$ Capital.

\subsection{3 - Aparência e essência em $O$ Capital}

Em $O$ Capital, Marx fala repetidamente em aparência e essência ou, equivalentemente, em exotérico e esotérico, em conexões de superfície e nexos internos.

É possível estabelecer uma correspondência entre a contraposição essência $x$ aparência e a contraposição abstrato $x$ concreto. Isto parece ser sugerido por vários textos do próprio Marx, inclusive por "O Método da Economia Política” e pelo parágrafo introdutório do Livro III citado acima ${ }^{30}$. Neste, Marx relaciona a exposição das "formas concretas que surgem do movimento do capital" com a aproximação "da forma em que elas mesmas aparecem na superfície da sociedade" [O Capital III-IV, p. 21]. A essência corresponderia ao abstrato, e a aparência ao concreto. Em particular, o Livro I trataria da essência do modo de produção capitalista. O Capital, começando pelo mais abstrato, começaria ao mesmo tempo pelo "mais essencial". Uma tal interpretação seria, de certa maneira, o oposto exato da de Ruy Fausto ${ }^{31}$.

É assim que as coisas são postas por Moishe Postone. Ao se contrapor a interpretações da relação entre valores e preços como as de Engels, Meek, e sobretudo as dos defensores do "método das aproximações sucessivas"32, como Dobb e Sweezy, para os quais a passagem aos preços de produção no Livro III representaria uma aproximação da realidade da economia capitalista, Postone diz o seguinte:

O movimento da exposição de Marx do primeiro para o terceiro livro de $O$ Capital deve, portanto, ser entendido não como um movimento de aproximação da "realidade" do capitalismo, mas como um movimento de aproximação das suas múltiplas formas de aparência. Marx não prefaciou o terceiro livro com uma declaração de que iria examinar um sistema capitalista completamente desenvolvido, nem afirmou que introduziria um novo conjunto de aproximações, de modo a apreender mais adequadamente a realidade capitalista. (...)

\footnotetext{
${ }^{30}$ Ver nota 28.

${ }^{31}$ Com a importante ressalva de que Ruy Fausto não tratou, nos textos comentados, do conjunto de $O$ Capital; concentrou-se na relação da Seção I com outras partes do Livro I.

${ }^{32}$ Que comentaremos na Seção 2.3.
} 
Enquanto a análise do valor no Livro I é a análise da essência do capitalismo, sua análise do preço no Livro III é a de como esta essência aparece na "superfície da sociedade" [Postone 1993, p. 134].

Postone toca num ponto chave: não há dúvida de que, para Marx, o preço é uma forma do valor, que o valor aparece como preço. E que de nenhum modo os preços de produção são "mais reais" que os valores ${ }^{33}$.

Mas dizer que o Livro I trata da essência do modo de produção capitalista, enquanto o Livro III trata de suas formas de aparência não se sustenta. Como vimos na subseção anterior, Marx trata da aparência do modo capitalista de produção — ou de uma parte fundamental dela — desde a Seção I do Livro I.

Seria possível dizer que o método de exposição de $O$ Capital envolveria começar pela aparência e depois voltar a ela?

É uma interpretação sedutora, mas tampouco se sustenta, pelo menos desta forma simples. Em primeiro lugar, registremos que seria preciso, pelo menos, esclarecer que a passagem da aparência para a essência começaria já na Seção I do Livro I. Além disto, examinando esta questão com mais detalhe, podemos observar que essência e aparência estão presentes ao longo de todo o livro.

A Seção I trata da aparência do capitalismo e da sua essência. Nas seções seguintes do Livro I, e também nos Livros II e III, ao sintetizar progressivamente mais determinações do modo de produção capitalista, Marx acrescenta tanto aspectos da essência quanto da aparência. Na Seção II do Livro I, por exemplo, trata tanto da exploração dos trabalhadores (essência) quanto de que a venda da força de trabalho aparece como venda de trabalho. Na Seção IV do mesmo Livro, trata da produção de mais-valia relativa (essência), mas igualmente de como o crescimento da força produtiva social do trabalho aparece como força produtiva do capital, e de como o capital parece ser uma coisa, e além disso necessário à produção (este é um aspecto do tema do fetichismo do capital, que é tratado extensivamente no Livro II e no Livro III). É possível mostrar que em todas as seções dos três Livros Marx trata tanto da essência quanto da aparência do modo de produção capitalista. Mesmo na Seção VII do Livro III (a última seção do livro), em que o tema privilegiado é a

\footnotetext{
${ }^{33}$ Trataremos de modo amplo desta questão no capítulo 4.
} 
aparência, e de certa forma a aparência do modo de produção capitalista no seu conjunto, o tema das classes sociais, por exemplo, que começa a ser tratado no último capítulo, diz respeito à essência.

Quando consideramos a relação entre essência e aparência ao longo de O Capital, portanto, fica difícil aceitar mesmo uma tese mais sofisticada do começo pela aparência e da volta a ela, como a defendida por Jairus Banaji. Este autor argumenta que o movimento em $O$ Capital é composto por vários ciclos que começam e terminam com a esfera da circulação, entendida como reino das aparências.

A estrutura total de $O$ Capital é melhor entendida em termos de uma imagem que o próprio Marx usa em um ponto. Ou seja, se é vista como uma "curva expansiva" ("expanding curve"), ou movimento em espiral, composta por sucessivos ciclos de abstração. Cada ciclo de abstração, e portanto a curva como um todo, começa e termina com a Esfera da Circulação (o reino das aparências), que é finalmente, no fim do movimento inteiro, determinada por sua vez como a Esfera da Concorrência dos Capitais [Banaji 1979, pp. 27-8].

A idéia de sucessivos ciclos de abstração corresponde à idéia de niveis de abstração que, como veremos na subseção 2.2.7, é sem dúvida importante para a compreensão da estrutura de $O$ Capital. Do mesmo modo, depois do que foi exposto acima, não podemos fazer nenhuma objeção à idéia de que cada nível de abstração inclui aparência e essência. O problema do argumento de Banaji é sua rigidez, sua definição de um modelo de exposição para todo $O$ Capital que não corresponde bem ao que encontramos no livro.

Parece mais razoável dizer apenas que em todos os níveis de abstração de $\mathrm{O}$ Capital Marx trata de aparência e essência. Os níveis de abstração em que se organiza o livro (o começo da exposição com o nível mais abstrato, e a redução progressiva do nível de abstração pelo acréscimo de mais determinações) não se distinguem por uma caminhada da essência para a aparência, e nem da aparência para a essência; mas tampouco por um movimento rigidamente repetido da aparência para a essência e de volta à aparência. A questão da relação essência $x$ aparência atravessa todo o livro, diz respeito a todos os níveis de abstração em que ele se articula. É transversal, como observou Alain Lipietz [Lipietz 1983, p. 21]. Não é possível, portanto, identificar essência com abstrato, aparência com concreto.

Finalmente, para concluir esta subseção, um esclarecimento adicional é útil. Dizer aparência não significa dizer ilusão. As aparências são um conjunto de realidade e irreali- 
dade, de verdade e ilusão. Como disse Hegel, a essência tem de aparecer [Hegel 1968, p. 421] - e ela aparece. Mas aparece numa forma distinta de si mesma, que a revela e esconde ao mesmo tempo. Se a realidade empírica traduzisse fielmente a essência, elas seriam uma coisa só, só haveria essência - e a ciência não seria necessária ${ }^{34}$. É possível distinguir na economia dois tipos de aparências, segundo Norman Geras:

a) (...) as aparências, ou formas de manifestação, em que as relações sociais se apresentam e que não são mistificatórias ou falsas em si mesmas, já que correspondem a uma realidade objetiva; tornam-se mistificadas apenas quando vistas como produtos da natureza ou das intenções subjetivas dos homens; e

b) as aparências, ou formas de manifestação, que são simplesmente falsas, ilusões no pleno sentido, não correspondendo a uma realidade objetiva [Geras 1971, p. 75].

Uma maneira de distinguir as duas situações é dizer que a ilusão do primeiro caso é objetiva, decorre de uma necessidade lógica do próprio objeto. Contrariamente, no segundo caso, a ilusão é puramente subjetiva; é engano, equívoco. Esta distinção é fundamental para a compreensão dos conceitos em $O$ Capital. Com o desenvolvimento do fetichismo da mercadoria (do dinheiro, do capital), as categorias em que as relações econômicas aparecem são fetiches, relações sociais fetichizadas; desta maneira constituem ilusões objetivas, uma mistura complexa de realidade e ilusão.

\subsection{4 - As alterações no Plano da Crítica da Economia Política}

Como observamos no fim da subseção 2.2.1, o texto "O método da Economia Política" termina com um plano da obra econômica a ser redigida, que não foi seguido nem em Para a Crítica da Economia Política, nem em O Capital.

Marx começou a modificar este plano durante a redação dos Grundrisse [Rosdolsky 2001, Capítulo 2, pp. 27-37; Oakley 1983, Chapter 4, pp. 52-80]. Aí foi se gestando um plano em 6 partes (ao longo do tempo, chamadas alternativamente de "Seções" e de "Livros"), citadas na abertura do "Prefácio" a Para a Crítica da Economia Política. São elas: Capital, propriedade fundiária, trabalho assalariado; Estado, comércio exterior, mercado mundial [Para a Crítica da Economia Política, p. 23]. Como é indicado parcialmente no

\footnotetext{
34 “(...) [T]oda a ciência seria supérflua se a forma de manifestação e a essência das coisas coincidissem imediatamente..." [Marx: O Capital III-V, p. 253].
} 
próprio prefácio, e podemos ver de forma mais detalhada nos Grundrisse ou em cartas escritas no período em que estes eram redigidos, a primeira parte (o livro do Capital) seria subdividida em quatro: Capital em geral, Concorrência dos capitais, Crédito e Capital por ações; a primeira parte do Livro do Capital seria subdividida em três "capítulos": Mercadorias, Dinheiro e Capital. Este terceiro "capítulo" incluiria três seções: o processo de produção do capital, o processo de circulação do capital, capital e lucro [Para a Crítica da Economia Política, p. 23; Rosdoslky 2001, p. 49; Oakley 1983, pp. 81-2].

O livro Para a Crítica da Economia Política foi publicado, em 1859, com os dois primeiros capítulos da primeira parte do Livro I — o livro do Capital. Entre 1859 e 1867, no entanto, quando foi publicado o Livro I do atual $O$ Capital, o plano sofreu modificações; e Marx se concentrou, a partir daí, na redação de $O$ Capital, fazendo apenas referências episódicas a eventuais outros livros.

Não há consenso quanto a quais foram exatamente as modificações do plano. Algumas coisas são claras: $O$ Capital evoluiu a partir daquilo que seria, no plano de 1859, a primeira parte (O Capital em Geral) do Livro do Capital; é possível, no entanto, argumentar que esta primeira parte cresceu incorporando temas que estavam inicialmente previstos para depois, e engoliu os livros seguintes.

Há basicamente três versões para qual teria sido, então, o plano definitivo ${ }^{35}$.

A primeira, é a de que, além do crescimento do volume da obra, só houve mudanças de detalhe no plano de 1859. O Capital (com seus três livros) corresponderia à primeira parte (das quatro partes previstas) do primeiro livro (de seis previstos). O defensor mais extremado desta posição é Enrique Dussel, para quem o Livro I, publicado por Marx, representa apenas 1/72 da obra projetada, e portanto os três livros no seu conjunto representam $1 / 24^{36}$; outros defensores são Maxilien Rubel [Rubel 1868, pp. XCIV-XCVII] e Michael Lebowitz [Lebowitz 1992, especialmente pp. 11-4].

\footnotetext{
${ }^{35} \mathrm{O}$ resumo que se segue foi baseado em Oakley 1983, pp. 107-8, no Capítulo 2 do livro de Rosdolsky [2001], em Rubel [1968] e Lebowitz [1992].

36 'De seu 'Plano', Marx só conseguiu publicar 1/72: apenas a 'produção do capital' (primeira de três partes, das quatro partes do tratado do capital; primeiro dos seis tratados projetados: $3 \times 4 \times 6=72$ )" [Dussel 1999, p. 139].
} 
A segunda versão é a de que Marx modificou o plano original absorvendo as outras partes do projetado Livro do Capital e os dois livros seguintes (sobre a propriedade da terra e sobre o trabalho assalariado) em $O$ Capital. Teriam ficado fora os três últimos livros, sobre o Estado, o comércio exterior e o mercado mundial. Esta posição foi defendida por Roman Rosdolsky [Rosdolsky 2001], Ronald Meek [Meek 1973, pp. VIII-X] e Ernest Mandel [Mandel 1976, pp. 25-32].

A terceira versão diz que depois dos anos 1860, Marx modificou seu plano original, de modo que $O$ Capital (incluindo os volumes publicados por Engels) abrange toda a sua “crítica da Economia Política”. Esta posição foi defendida por Karl Kautsky e Henrik Grossmann [Grossmann 1979].

$\mathrm{Na}$ verdade, é muito claro que os temas do Estado, do comércio exterior e do mercado mundial não foram abordados de forma sistemática em $O$ Capital. A terceira posição, portanto, só pode ser entendida no sentido de que Marx passou a considerar que estes temas não eram necessários ao seu projeto, ou pelo menos não eram essenciais. Em uma carta escrita por ele em 1862, quando ainda defendia o plano em seis livros, ele já apresentava a parte então chamada de "o capital em geral" como a mais importante — a "quintessência":

A segunda parte [de Para a Crítica da Economia Política, que era então visto por Marx como a primeira parte do primeiro livro dos seis previstos - JM] está agora enfim terminada, isto é, exceto a revisão e o último polimento para a impressão. (...) É a seqüência do fascículo I, mas a obra aparecerá separadamente sob o título $O$ Capital, e "Contribuição à Crítica da Economia Política" só figurará como subtítulo. De fato, a obra só engloba o que deveria constituir o terceiro capítulo da primeira parte: "O Capital em Geral". Não estão portanto incluídas a concorrência dos capitais nem o crédito. Este volume conterá o que os ingleses chamam de "princípios da Economia Política". É (junto com a primeira parte) a quintessência, e o desenvolvimento do que virá a seguir poderia facilmente ser realizado por outros, sobre a base do que já está escrito (com exceção talvez da relação entre as diversas formas do Estado e as diversas estruturas econômicas)... [Marx a Kugelmann, 2812-1862, in Marx e Engels, 1964, p. 130].

De fato, $O$ Capital ainda demoraria cinco anos para ter seu Livro I publicado (o que representa apenas a primeira parte do que Marx anunciava na carta já ter quase pronto); nesse meio tempo o projeto sofreria modificações, e o "capítulo" "O Capital em Geral”, transformado em três livros, concentraria todos os esforços. Por outro lado, como esta carta 
foi escrita claramente no quadro do projeto de seis livros, é possível concluir que os três livros de $O$ Capital representam a "quintessência" da obra no seu conjunto, mesmo na versão que mais acentua seu caráter incompleto.

O aprofundamento desta discussão vai além dos objetivos desta tese. Para estes, só é importante assinalar que qualquer das três versões é compatível com a concepção de que a exposição em $O$ Capital seguiu o método de "elevar-se do abstrato ao concreto", ou pelo menos de começar com o mais simples e progressivamente chegar ao mais complexo. Qualquer das três versões pode ser considerada uma variação do plano exposto por Marx ao final do texto sobre o método; a supressão do que deveria ser a primeira "seção" — as determinações abstratas gerais - não impede que, em qualquer das versões, seja possível dizer que o nível de complexidade cresce progressivamente. De fato, nenhum dos autores que afirmam que Marx abandonou o "método de elevar-se do abstrato ao concreto" justifica esta posição com base na mudança do plano da obra.

\subsection{5 - Outro começo; outro método?}

Estamos agora em condições de retomar a discussão da pergunta colocada no final da subseção 2.2.1 deste capítulo. O "método de elevar-se do abstrato ao concreto" foi mantido em $O$ Capital, apesar da possível mudança no plano da obra e, principalmente, da escolha da mercadoria como ponto de partida?

Para muitos estudiosos, nenhuma das duas questões é suficiente para lançar dúvidas sobre a visão geral sobre método resumida na subseção $2.2 .1^{37}$. Para mencionar apenas alguns autores que são uma referência para esta tese e que tratam com destaque deste tema: Roman Rosdolsky toma o "método de elevar-se do abstrato ao concreto" como uma referência fundamental na discussão da estrutura da obra de Marx [Rosdolsky 2001, Capítulo

\footnotetext{
${ }^{37}$ Rafael Echeverria afirma mesmo, de modo bastante exagerado: "Tanto quanto sabemos, não há exceções a esta abordagem para o problema da lógica da investigação de Marx”, referindo-se à assunção da identidade entre a discussão sobre método de 1857 e o método de $O$ Capital. Ele prossegue: "A Introdução de 1857 foi elevada ao posto de autoridade para a decodificação da lógica de $O$ Capital a partir de diversas posições políticas e teóricas, produzindo interpretações diversas. Althusser atribuiu à Introdução o nível de Discurso do Método de Marx. Em geral, o conteúdo deste texto foi tratado acriticamente como a posição de Marx sobre a lógica da investigação" [Echeverria, 1978, p. 334]. Veremos a seguir que não é este o caso.
} 
2, pp. 27-74]; o mesmo fazem Ernest Mandel, na esquematização reproduzida acima (e no conjunto da discussão que a precedeu) [Mandel 1985, pp. 7-10], tomando apenas o cuidado de precisar que a "progressão do abstrato ao concreto" na exposição exige uma prévia "progressão do concreto ao abstrato" na investigação, e Tony Smith [Smith 1990, especialmente Capítulos 1 e 2, e Smith 1993, especialmente p. 115] ${ }^{38}$.

Para outros autores, no entanto, do texto de 1857 para $O$ Capital as mudanças de método foram decisivas. Uma opinião influente é a de Martin Nicolaus, que traduziu os Grundrisse para o inglês pela primeira vez, para Penguin Books. No prefácio desta edição, ele chama a atenção, corretamente sem dúvida, para o fato de que, no decorrer da redação dos Grundrisse, Marx decidiu-se por começar sua exposição pelo conceito de mercadoria; a primeira vez em que este ponto de partida foi adotado foi no fragmento sobre o valor do final desta obra. Nicolaus interpreta que a adoção da mercadoria como ponto de partida representa uma opção por começar pelo concreto, e um abandono da concepção da progressão do abstrato ao concreto.

É esta categoria, a mercadoria, que forma o ponto de partida (...) de O Capital (1867). É um começo que é tanto concreto, material, quase tangível, quanto historicamente específico (a produção capitalista); e ele contém em si (é a unidade de) uma antítese chave (valor de uso $x$ valor de troca), cujo desenvolvimento envolve todas as outras categorias deste modo de produção. Ao contrário da Lógica de Hegel, e das próprias tentativas iniciais de Marx antes, este começo não começa com uma abstração pura, indeterminada, eterna e universal, mas antes com um todo composto, determinado, delimitado e concreto - "uma concentração de muitas determinações, logo unidade do diverso" "39. Em uma palavra, este começo 'impuro' com o qual os Grundrisse terminam é superior, como dialética, aos pontos de partida prévios, porque contém contradição desde o início, em embrião (...). Só um começo materialista, isto é, o começo com o concreto, o determinado, e logo (como o próprio Hegel sustentava) o contraditório mesmo, pode portanto ser um começo verdadeiramente dialético, e só ele pode realizar os poderes latentes no método que Hegel tanto aperfeiçoou quanto mistificou.

\footnotetext{
${ }^{38}$ Como vimos na nota 5, também Tony Smith chama a atenção para um estágio de "apropriação" antes do estágio de "reconstrução" em que a ascensão do abstrato ao concreto é feita.

${ }^{39}$ Nesta citação do texto $O$ método da Economia Política seguimos a tradução ao inglês feita pelo próprio Nicolau.
} 
(...) A noção de que o caminho da investigação ${ }^{40}$ deve proceder das relações simples, gerais, abstratas para todos particulares complexos não mais parecia a ele, então, como "obviamente o procedimento científico correto" [Nicolaus 1973, p. 38].

Para Nicolaus, portanto, só um começo materialista, pelo concreto, o determinado, o contraditório (ou seja, o que contém em si o diverso) ${ }^{41}$ pode ser verdadeiramente dialético $^{42}$, e este foi o ponto de vista de Marx desde o final da redação dos Grundrisse.

Outro autor que conclui, a partir do começo da exposição pela mercadoria, que Marx abandonou o método de "elevar-se do abstrato ao concreto", é Rafael Echeverria [Echeverria 1978 e 1980]. Após examinar criticamente a Introdução /1857, ele resume sua posição num texto denso, que merece uma citação longa.

A mercadoria é concreta, mas também um concreto simples. Diferentemente da posição assumida na Introdução, a identidade entre o abstrato e o simples é quebrada. Entretanto, isto invalida a unidade do argumento proposto na Introdução para o ponto de partida. Marx ainda afirma que a totalidade concreta, sendo a concentração e a unidade de várias determinações, não pode constituir o ponto de partida da análise. Ele ainda afirma a necessidade da abstração para fazer a explanação da totalidade concreta. Entretanto, não é deduzido daí que o ponto de partida deve ser abstrato. Os mesmos conceitos abstratos que a ciência deve usar precisam ser apoiados no concreto e derivados dele. Se a totalidade concreta emerge, do ponto de vista do conhecimento, de determinações abstratas, estas por sua vez requerem condições concretas a partir das quais podem ser extraídas. Marx tinha compreendido previamente que conceitos abstratos são determinados por condições históricas concretas. Até agora, entretanto, isto só tinha sido reconhecido do ponto de vista da determinação prática das categorias científicas. Agora é visto também como uma exigência lógica da análise. $\mathrm{O}$ processo global da lógica da exposição não pode se apoiar apenas no reconhecimento da determinação concreta de conceitos abstratos. Deve reproduzir este reconhecimento numa

\footnotetext{
${ }^{40}$ De fato, Marx falava do caminho da exposição científica, não da investigação.

${ }^{41}$ Para reforçar o caráter concreto do começo, Nicolaus indica aqui os vários sentidos que esta palavra pode ter. Cria, com isto, uma certa falta de clareza.

${ }^{42}$ A questão da dialética, e portanto do caráter dialético do começo, será comentada depois, na subseção 2.2.6. Antecipemos apenas que a afirmação de que a mercadoria é um ponto de partida dialeticamente superior às determinações válidas para qualquer forma de sociedade que haviam sido indicadas antes como ponto de partida é o argumento mais forte usado aqui por Nicolaus.
} 
seqüência lógica específica, apoiando os conceitos abstratos nesta realidade concreta, que os torna possíveis. (...) É necessário que a lógica do pensamento seja capaz de expressar a prioridade do concreto com relação às variantes do pensamento que não encontram uma referência direta na realidade. Esta prioridade lógica é afirmada numa determinada seqüência entre conceitos abstratos e concretos [Echeverria 1978, pp. 355-6].

Echeverria, portanto, argumenta que um concreto deve ser o ponto de partida pela necessidade de apoiar os conceitos abstratos numa realidade concreta, para "expressar a prioridade do concreto com relação às variantes do pensamento que não encontram uma referência direta na realidade". O concreto inicial, portanto, funciona como uma base de apoio para os conceitos abstratos subseqüentes. Por outro lado, este concreto do qual se parte não é a totalidade concreta, que continua sendo vista como um resultado a ser atingido no fim da investigação. É um "concreto simples".

O ponto de partida é portanto a unidade econômica concreta de um modo particular de produção. É a expressão simples e particular concreta (em oposição à totalidade concreta) de uma fase particular (em oposição a pertencente a todas as formas de sociedade) [Echeverria 1978, p. 356].

Toda esta argumentação se apóia numa interpretação das passagens das Notas sobre Wagner citadas acima:

A importância de ter um ponto de partida concreto, nos termos de Marx, é dada como um modo de iniciar a análise a partir da base mais firme possível. Se, como Wagner sugerira, Marx tivesse começado pelo conceito abstrato de valor, todos seus desenvolvimentos teóricos subseqüentes teriam ficado sujeitos à discussão de um tal conceito inicial. Isto parece explicar a preocupação de Marx de se opor à interpretação de Wagner e de enfatizar o caráter concreto de seu ponto de partida. O conceito abstrato de valor, que Marx indubitavelmente usa, tem base na análise da realidade concreta da qual foi derivado [Echeverria 1978, p. 359].

Podemos dizer que os pontos centrais desta argumentação de Echeverria são:

1) Marx manteve alguns dos aspectos da orientação metodológica exposta na Introdução / 1857, os de que a exposição deve caminhar do simples ao com- 
plexo $^{43}$ e de que o concreto como totalidade deve ser o ponto de chegada, e ser reproduzido a partir de determinações abstratas.

2) Há no entanto uma mudança decisiva: não basta afirmar que o concreto é o ponto de partida da investigação prévia ao início da exposição; é necessário começar a exposição apoiando as determinações abstratas iniciais no concreto — num concreto simples, como é no caso a mercadoria, mas determinado historicamente.

3) Em resumo, a exposição deve começar com um concreto simples, derivar daí conceitos abstratos, e reproduzir então a partir deles a totalidade concreta; o caminho pode então ser resumido como:

concreto simples $\rightarrow$ determinações abstratas $\rightarrow$ totalidade concreta (complexo).

É perfeitamente legítimo concluir que, segundo Echeverria, a mudança de método não foi afinal assim tão grande. Basicamente, ele aponta que o ponto de partida tornou-se mais complexo; a partir daí, aceita que a exposição de Marx não apenas segue do mais simples ao mais complexo, mas que isto igualmente representa uma progressão do abstrato ao concreto. Apesar de seu tom muito crítico com relação à Introdução / 1857, a conclusão deste autor é que o método de $O$ Capital não se afasta muito do que é aí proposto.

Esta proximidade de Echeverria com a Introdução / 1857 pode também ser confirmada indiretamente: um autor que não compartilha sua opinião crítica sobre este texto, o já citado Jairus Banaji, tem uma interpretação do começo de $O$ Capital que é bastante semelhante.

Banaji se contrapõe à interpretação de Nicolaus. Após citar a frase de Marx que diz que o concreto aparece no pensamento como um resultado, diz que "a mercadoria que forma o ponto de partida não pode ser então, por nenhum esforço da imaginação, um 'todo concreto ${ }^{44}$ no sentido sugerido por Nicolaus" [Banaji, 1979, p. 27]. Acrescenta que esta confusão levou Nicolaus a rejeitar a idéia de que a exposição para Marx segue o caminho

\footnotetext{
${ }^{43}$ Echeverria não é o único a propor esta versão do método de Marx; Geert Reuten [1993, p. 96] sugere esta interpretação.

${ }^{44}$ Banaji não nega que a mercadoria seja um concreto; nega apenas que seja o todo concreto, isto é, o ponto de chegada do processo de reconstrução do real no pensamento.
} 
do simples e abstrato para o concreto e complexo, e conclui que isto, "se fosse verdadeiro, tornaria todo o movimento da dialética algo incompreensível” [Idem, p. 27]. Resume o erro de Nicolaus da seguinte maneira:

a partir do fato de que Marx não começa com um abstrato historicamente indeterminado, a produção em geral, Nicolaus conclui que Marx não começa com um abstrato de nenhuma maneira [Idem, p. 27].

Assim, Banaji considera a idéia da progressão do abstrato ao concreto fundamental para a compreensão de $O$ Capital. E diz que Marx começa, sim, com o abstrato. Mas não é possível ignorar que o concreto também está presente no ponto de partida. A saída é dizer que o ponto de partida é duplo:

(...) [O] começo é um movimento entre dois pontos de partida. (...) [A] mercadoria individual forma o ponto de partida analítico. Daí, entretanto, não passamos diretamente ao conceito de capital. Analisando a mercadoria, desvendando suas determinações, chegamos ao conceito de valor como a forma abstrata-reificada do trabalho social. Isto, como o fundamento de todas a determinações conceituais posteriores (dinheiro, capital) forma o ponto de partida sintético de $O$ Capital. (...) A passagem de um ponto ao outro constitui a dupla estrutura do começo como tal. (...) A análise é simplesmente um prelúdio, como Marx aponta, mesmo se um prelúdio necessário, ao processo que ele chama de 'exposição genética' (genetische Darstellung) (Teorias da Mais-Valia). Este é o movimento geneticamente contínuo do abstrato ao concreto, o movimento que Hegel chama 'o desenvolvimento da forma', o movimento que Marx descreve como 'o princípio entrando na aparência', ou o desenvolvimento das diversas formas através de suas gênesis internas. [Banaji, 1979, p. 3940]

A idéia de um ponto de partida concreto, a partir do qual se realiza uma análise, que "é apenas um prelúdio, embora um prelúdio necessário", que se move para um ponto de partida sintético, a partir do qual se faz a "exposição genética", pode ser tomada como uma formulação um pouco mais sofisticada da interpretação de Echeverria, para quem o concreto que serve de ponto de partida é um apoio para os conceitos abstratos, a partir dos quais a construção posterior das categorias é feita.

Uma interpretação na mesma linha permite explicar também por que Marx começa O Capital fazendo referência à aparência, e por que a aparência do capitalismo como circulação simples tem um lugar tão importante na Seção I. A frase 
A riqueza das sociedades em que domina o modo de produção capitalista aparece como "uma imensa coleção de mercadorias"; a mercadoria individual como sua forma elementar. Nossa investigação ${ }^{45}$ começa, portanto, com a análise da mercadoria [O Capital I-I, p. 45; El Capital I-I, p. 43].

pode ser entendida no sentido de que o começo pela aparência, por um concreto (a mercadoria) que em alguma medida aparece $^{46}$, constitui uma porta de entrada pela qual é possível fundamentar os conceitos abstratos que se seguem.

Lembremos, finalmente, que Marx faz um uso de abstrato e concreto como termos relativos; por isso podemos falar de níveis de abstração. $\mathrm{O}$ mais simples inclui menos determinações, e por isto é mais abstrato que o mais complexo, que inclui mais determinações. A mercadoria de que a exposição parte é um concreto, mas tomado da forma mais simples possível. Diversas determinações da mercadoria não estão ainda postas no começo; por exemplo, não está posta a determinação fundamental de que, no capitalismo, as mercadorias são produtos do capital. Logo, a mercadoria é tomada inicialmente da forma mais abstrata. A Seção I de $O$ Capital é sem dúvida a mais abstrata de todo o livro, embora seu ponto de partida - a mercadoria - seja um concreto, nos sentidos de unidade do diverso, de historicamente determinado e de algo que aparece.

O que é fundamental no método de elevar-se do abstrato ao concreto não é partir do abstrato; ele não exige começar com conceitos abstratos. Exige começar com o mais simples possível - neste sentido, com o mais abstrato possível - e caminhar para a totalidade concreta pela síntese progressiva de múltiplas determinações. O começo deve permitir que se faça a partir dele a reprodução conceitual da realidade. Deve ser anterior logicamente a todos os outros conceitos que fazem parte da totalidade que se busca reconstruir (por isto deve ser o mais simples possível). Ao mesmo tempo, deve ser concreto, no sentido de diferenciado dentro de si mesmo, para poder ser objeto de análise. O começo da exposição deve, ainda, mostrar seu vínculo com o verdadeiro ponto de partida, que é o

\footnotetext{
${ }^{45}$ É útil observar que Marx usa aqui o termo investigação em um sentido diferente da investigação prévia ao início da redação. O que ele começa com esta frase é a exposição; o termo investigação pode ser usado porque a exposição reproduz certos aspectos, certas conclusões da investigação.

${ }^{46}$ Podemos dizer que um concreto que aparece corresponde ao "real e concreto" do texto de 1857 sobre o método.
} 
real e concreto; deve aparecer como parte desta realidade; portanto, deve ser historicamente determinado.

A avaliação da discussão sobre o texto "O método da Economia Política" e da questão do método de $O$ Capital pode concluir com uma combinação das posições de Echeverria e Banaji, da maneira resumida acima. O que nos leva à seguinte resposta à pergunta formulada no fim da subseção 2.2.1: o texto de 1857 não representa a última palavra de Marx sobre o método de exposição de $O$ Capital; mas as mudanças posteriores mais complementam certos aspectos da discussão feita aí do que representam uma mudança fundamental. O "elevar-se do abstrato ao concreto" não resume, certamente, todo o método de $O$ Capital; mas é um aspecto central dele.

\subsection{6 - A dialética}

É necessário, agora, explicitar uma questão central numa discussão do método de $O$ Capital: seu caráter dialético.

Esta questão pode ser abordada de muitas maneiras. Aqui, é suficiente enfatizar dois pontos.

O primeiro é a importância decisiva da contradição como algo existente na realidade, e portanto da unidade na diversidade ou da unidade de contrários como características que devem necessariamente estar presentes nos conceitos com que a teoria busca apreendê-la. Este ponto fica claro quando nos lembramos da dualidade das categorias centrais da economia de Marx estudadas no Capítulo 1.

O segundo ponto é o caráter sistemático da progressão das categorias com as quais o "real e concreto" vai sendo reconstruído no pensamento. Tony Smith fundamenta este ponto com grande clareza:

O Capital de Marx pode ser lido como uma reconstrução no pensamento do modo capitalista de produção. Uma reconstrução no pensamento de uma forma de produção social necessariamente envolve o uso de categorias. Para ser abrangente, requer um sistema de categorias. Estas categorias não ficam todas no mesmo nível teórico. Algumas categorias articulam estruturas sociais que são mais simples e abstratas do que outras. Para nossos objetivos, pode-se dizer que uma teoria segue uma lógica dialética se: a) categorias que articulam estruturas sociais simples e abstratas são colocadas antes de categorias que definem estruturas mais complexas e concretas, e b) cada categoria fixa uma estrutura que incorpora as es- 
truturas apresentadas nas categorias prévias e por sua vez é incorporada nas estruturas fixadas pelas categorias subseqüentes [Smith 1993, p. 115].

A lógica dialética é o método que nos permite movermo-nos sistematicamente de uma determinação do pensamento para outra [Smith 1993, p. 36].

Christopher Arthur enfatiza também o caráter sistemático de uma exposição dialética:

Se miramos Hegel e Marx, é claro que a análise de todos (wholes) através de um argumento dialético sistemático é o mais importante em seu trabalho. O problema que quero tratar é: em que exatamente consiste o método lógico de desenvolvimento do argumento em $O$ Capital? Ele deve ser adequado a seu objeto: eu argumento que o objeto é uma espécie de todo. De qual tipo? Bem, não é uma mera agregação; isto nós temos numa pilha de tijolos, onde um tijolo é posto casualmente sobre o outro. É, antes, uma totalidade, em que cada parte claramente requer a complementação de outras para ser o que é; logo, relações internas caracterizam o todo, de modo que a essência mesma de cada elemento depende de sua relação com outros e com o todo. Uma coisa relaciona-se internamente com outra se esta outra é uma condição necessária de sua natureza. Não podemos dizer 'o que é' sem referência a todo o contexto de suas relações e determinações. Se os elementos estão ligados em um tal todo, podemos até falar de uma causalidade holística que traz uma transformação substancial das esferas envolvidas.

O problema que enfrentamos é que uma totalidade não pode ser apresentada imediatamente; sua articulação tem de ser exibida; temos de começar em algum lugar, com algum aspecto dela. Mas na exposição o argumento pode mover-se através da reconstrução do todo a partir de um começo porque podemos mover-nos logicamente de um elemento a outro ao longo de uma cadeia de relações internas; em estrita lógica, se o sentido mesmo de um elemento está em questão (o que, argumento, é o caso nas formas do valor mercadoria - dinheiro - capital, cada uma das quais requer as outras para completar seu sentido ou desenvolver seu conceito), ou com um razoável grau de confiança se condições materiais de existência estão envolvidas (como com a relação de valorização com a produção) [Arthur 1996, p. 194].

Esta concepção da exposição sistemática das categorias dá um especial relevo à questão do ponto de partida da exposição. Como vimos, ele deve ter características que tornem possível empreender o movimento de reconstrução da realidade no pensamento deve ser portanto um concreto, no sentido de diferenciado em si mesmo, de unidade do diverso; além disto, deve ser o mais simples possível. 
Naturalmente, o caráter contraditório dos conceitos se manifesta também no sistema como um todo. A passagem do simples ao complexo não se faz apenas acrescentando determinações que se ligam às anteriores; se a estrutura conceitual se torna progressivamente mais complexa, ela também une determinações mais diversas. Como diz Ruy Fausto: "A novidade da dialética é que o complexo vem a ser o contraditório do simples" [Fausto 1983d, p. 194].

O caráter sistemático da reprodução conceitual da realidade torna, em $O$ Capital, o método de ordenar a exposição e a arquitetura do conjunto tão ou mais importantes que a definição de cada conceito. É o conjunto desta construção que constitui o esforço de Marx para desvendar o funcionamento da economia capitalista; é impossível compreender os conceitos de $O$ Capital isoladamente.

A fonte fundamental desta concepção metodológica é a dialética hegeliana. Talvez a afirmação mais enfática de sua importância para a compreensão da obra de Marx seja o aforismo proposto por Lênin em seus Cadernos Filosóficos:

Aforismo: É completamente impossível entender O Capital de Marx, e em especial seu primeiro capítulo, sem ter estudado e entendido a fundo toda a Lógica de Hegel. Por conseguinte, há meio século nenhum dos marxistas entendeu a Marx! [Lênin 1972, p. 172]

Este aforismo está no "Resumo da Ciência da Lógica de Hegel”, redigido em 1914. O "meio século" começa, portanto, antes da publicação do Livro I de O Capital. A afirmação é, pois, que nenhum marxista até a época tinha entendido Marx, com a possível exceção de Engels.

\subsection{7 - A estrutura dos níveis de abstração em $O$ Capital}

A discussão sobre o método de $O$ Capital nas subseções anteriores nos permite concluir que a organização da exposição em níveis de abstração, já anunciada no texto de 1857, se manteve. A progressão das categorias vai do simples e abstrato ao complexo e concreto; além disto, a relação da essência com a aparência é feita transversalmente, está presente em todos os níveis de abstração. Por isso, o passo fundamental para a compreensão da lógica dos conceitos em $O$ Capital é o de apreender a lógica do ordenamento dos temas, e, conseqüentemente, o de identificar o nível de abstração em que cada conceito é colocado. É possível agrupar seus temas em quatro grandes níveis de abstração: 
1) O nível da Seção I do Livro I, Mercadoria e Dinheiro, que é constituída de três capítulos. Este nível de abstração pode ser chamado de mercadoria em geral, ou de características gerais da economia mercantil. Marx trata de forma genérica do funcionamento de uma economia mercantil, sem introduzir ainda a especificação da relação capital-trabalho, isto é, da especificidade da economia capitalista (mas apesar disto a economia capitalista já está pressuposta, como foi discutido na subseção 2.2.2).

2) O segundo grande nível de abstração inclui o restante do Livro I. Marx trata das relações entre capital e trabalho no processo de produção. São consideradas apenas características gerais do capital no processo de produção e circulação, ou seja, o capital é tratado do ponto de vista do capital em geral.

O ponto de partida deste nível de abstração é a análise da circulação do capital, feita no Capítulo IV do Livro I (Seção II). Aí é mostrado que a explicação da origem da maisvalia exige mudar o nível da análise, considerar a relação capital-trabalho, e mergulhar no processo de produção, o que é feito no resto do Livro I. Neste nível já é possível deduzir algumas leis de desenvolvimento mais gerais da economia capitalista: a tendência à produção de mais-valia relativa (pela incorporação contínua de progresso técnico) e a tendência à polarização econômica e social que é chamada de lei geral da acumulação capitalista.

A importância da categoria de capital em geral, explicitada por Marx a partir dos Grundrisse, foi posta em relevo principalmente por Roman Rosdolsky [Rosdolsky 2001, pp. 49-56]. Recentemente Paul Burkett [1991] e Fred Moseley [1995] reafirmaram esta importância, respondendo a uma crítica de Michael Heinrich [1989]. O capital em geral contrapõe-se aos muitos capitais e à concorrência; é neste nível que Marx trata da produção da mais-valia "em geral", isto é, como algo logicamente anterior à sua distribuição em várias formas (lucro industrial, lucro comercial, juro, renda da terra) e entre os vários agentes. Marx considerava este tratamento da mais-valia em geral como um dos maiores méritos de sua teoria, ao lado da afirmação do duplo caráter do trabalho produtor de mercadorias.

3) O terceiro grande nível de abstração, que abrange o Livro II, é o da circulação do capital, tomada ainda do ponto de vista do capital em geral. Completada a análise do processo de produção, ao final do Livro I, é necessário retomar o estudo da circulação, o que é feito no Livro II. Nas duas primeiras seções deste livro, a análise da circulação do capital, iniciada no Capítulo IV do Livro I, é retomada, desdobrada e concretizada. Por 
outro lado, a Seção III do Livro II, que se centra nos esquemas de reprodução, já trata a produção e a circulação do capital em conjunto ${ }^{47}$, realizando assim uma redução do nível de abstração, e funcionando portanto como uma transição para o Livro III.

4) O quarto grande nível de abstração é constituído pelo Livro III de O Capital. Corresponde à inclusão da diversidade dos capitais e da concorrência entre eles na análise; e à aproximação da "superfície da sociedade" capitalista, ao ponto de vista da "consciência costumeira dos agentes da produção" [O Capital III-IV: 21]. Abreviadamente, costuma ser chamado de nível dos muitos capitais. No entanto, parte do Livro III ainda trata do capital em geral: a primeira seção, que trata da transformação da mais-valia em lucro no contexto do capital em geral [Moseley 1995]; e a Seção III, que trata da lei da tendência à taxa decrescente de lucro.

A Seção II representa, de certa forma, uma transição para o tratamento dos muitos capitais: ocupa-se da concorrência dos capitais industriais e da formação dos preços de produção, mas não ainda das formas particulares do capital (capital comercial, capital que rende juros) e da renda da terra, o que é feito nas seções IV, V e VI. Estas seções tratam da diferenciação da mais-valia e da sua distribuição (transformação da mais-valia em lucro, formação dos preços de produção, do lucro comercial e dos preços dos comerciantes, divisão do lucro em juro e ganho empresarial, renda da terra).

A Seção VII, a última de todo o livro, sistematiza a aparência da economia capitalista, em torno do tema de como as coisas aparecem invertidas na concorrência.

Esta divisão em quatro grandes níveis de abstração, por sua vez, pode ser mais concretizada, isto é, estes níveis podem subdividir-se. Por exemplo: no Livro III, Marx começa tratando a questão do lucro, da taxa de lucro e dos preços de produção, ignorando a influência do capital comercial sobre estas categorias; a partir do capítulo XVI, e especialmente no capítulo XVII, esta determinação é incluída. Mas ainda estão sendo ignoradas a divisão do lucro em juro e ganho (lucro) do empresário e a questão da renda da terra, que só são analisadas depois.

\section{3 - O "MÉTODO DAS APROXIMAÇÕES SUCESSIVAS"}

\footnotetext{
${ }^{47}$ Como o próprio Marx observa no parágrafo introdutório ao Capítulo I do Livro III [O Capital III-IV: 21].
} 
Vimos que "elevar-se do abstrato ao concreto" é um aspecto fundamental do método de Marx em O Capital. É necessário ter claro que este método não é igual ao que costuma ser chamado de "método das aproximações sucessivas", e que podemos resumir da seguinte maneira: começar introduzindo muitas hipóteses simplificadoras, que depois são progressivamente relaxadas; à medida que estas hipóteses vão sendo retiradas, aproximamo-nos cada vez mais da realidade.

Economistas marxistas importantes confundem os dois métodos. É o caso de Maurice Dobb, no seu livro clássico Economia Política e Capitalismo [Dobb 1945, publicado em inglês inicialmente em 1937], e de Paul Sweezy, no seu muitíssimo influente Teoria do Desenvolvimento Capitalista [Sweezy 1967, publicado em inglês inicialmente em 1942]. Estes livros foram decisivos na formação de gerações de economistas marxistas.

No primeiro capítulo de seu livro, “O método de Marx”, Sweezy afirma o seguinte: Marx acreditava e praticava o que os teóricos modernos chamam de método de 'aproximações sucessivas', e que consiste em passar do mais abstrato para o mais concreto, em fases sucessivas, afastando suposições simplificadoras nos sucessivos estágios da investigação, de modo que a teoria possa explicar e levar em conta um número de fenômenos cada vez maior [Sweezy 1967, pp. 39-40].

Dobb se refere ao método de Marx da mesma maneira [1945, principalmente Capítulos 1 e 3].

Segundo o método das "aproximações sucessivas", a exposição começa com um modelo muito simples e muito irrealista, porque assume muitas hipóteses simplificadoras contrafactuais. Os últimos modelos se aproximam mais da realidade porque não assumem hipóteses contrafactuais, ou as assumem com menos abundância. A "mitodologia" de Ronald Meek pode ser considerada, portanto, uma variante sofisticada deste método. Além disto, ele corresponde a uma concepção de modelização amplamente utilizada na economia neoclássica. Esta compreensão do método de Marx é compartilhada por quase todos os seus críticos, de Böhm-Bawerk e Bortkiewicz até os mais modernos sraffianos.

No entanto, quando comparamos esta concepção das "aproximações sucessivas" com o método de Marx com algum cuidado, vemos que ambos são em muitos sentidos não apenas distintos, mas opostos. Nas "aproximações sucessivas", o primeiro "modelo" é o menos geral, pois contém mais hipóteses simplificadoras, e o último é o mais geral, porque contém menos hipóteses. No método de Marx, ao contrário, a progressão do abstrato ao 
concreto se faz sintetizando progressivamente mais determinações; acrescentar determinações, é claro, significa restringir, reduzir o grau de generalidade. Para passar da Seção I ao Livro III, segundo as "aproximações sucessivas", é preciso retirar a hipótese simplificadora de que as mercadorias se vendem (na média) por seus valores; para fazer a mesma passagem segundo Marx, o que é preciso é acrescentar a relação capital-trabalho, a diversidade dos capitais e a concorrência entre eles.

O método de Marx visa "reproduzir o concreto no pensamento"; mantém em todos os momentos a realidade concreta como referência; ela está sempre pressuposta. Não é possível, portanto, introduzir hipóteses simplificadoras contrafactuais, a não ser no sentido estrito de simplificações que não alteram o fundamento do argumento. É exatamente neste sentido que Marx adota no Livro I a hipótese da venda das mercadorias por seus valores. Vejamos como isto acontece. No Capítulo IV, após formular a hipótese de que as mercadorias são vendidas por seus valores, Marx insere a seguinte nota:

De acordo com esta discussão, o leitor compreende que isso significa apenas: a formação de capital tem de ser possível também quando o preço da mercadoria seja igual ao valor da mercadoria. Ela não pode ser explicada pelo desvio dos preços das mercadorias em relação aos valores das mercadorias. Se os preços se desviam realmente dos valores, então é preciso começar por reduzi-los aos últimos, ou seja, abstrair esta circunstância como sendo casual, para ter pela frente, em sua pureza, o fenômeno da formação de capital com base no intercâmbio de mercadorias e não ser confundido em sua observação por circunstâncias secundárias, perturbadoras e estranhas ao verdadeiro decurso [O Capital I-I: 134, nota 37].

Ou seja, esta hipótese simplificadora é legítima porque apenas simplifica, não altera o fundo do problema que está sendo analisado. Marx já havia demonstrado que a mais-valia não pode ser explicada por desvios dos preços em relação aos valores; portanto, tratar destes desvios aqui apenas complicaria as coisas desnecessariamente.

Alguns autores que se ocuparam com a questão da relação entre valores e preços de produção (que discutiremos no Capítulo 4) criticam, e por vários ângulos, esta concepção das "aproximações sucessivas". Fred Moseley diz o seguinte:

Podemos ver, a partir da distinção metodológica de Marx entre capital em geral e muitos capitais, que a interpretação das 'aproximações sucessivas' do método de Marx, adotada por Sweezy e por muitos outros, é errônea. De acordo com a interpretação das aproximações sucessivas, o Livro I de $O$ Capital faz a suposição simplificadora de que os preços das mercadorias individuais são iguais (ou proporcionais) a seus valores, e que a composição 
do capital em todas as indústrias é igual. Depois, no Livro III, composições desiguais dos capitais são introduzidas, e uma teoria mais realista dos preços é desenvolvida. (...) Entretanto, de acordo com a distinção de Marx entre capital em geral e muitos capitais, a análise do Livro I do capital em geral desconsidera tanto os preços das mercadorias individuais quanto as composições dos capitais individuais. Nenhuma suposição é feita sobre a igualdade das composições individuais dos capitais, porque capitais individuais não entram na análise $^{48}$ [Moseley 1993c: 182, nota 3].

Alan Freeman caracteriza o sentido do nível mais abstrato para Marx tomando o exemplo da geometria euclidiana, e contrapondo seu método ao das "simplificações":

A palavra 'simplificação' é usada abusivamente na literatura. O método axiomático abstrai fatores particulares que são reintroduzidos num estágio posterior. O poder da geometria euclidiana, o mais belo exemplo clássico deste método, reside na formulação de axiomas a respeito de retas e pontos que expressam apenas as relações entre eles. A largura de uma reta euclidiana ou o tamanho de um ponto euclidiano não são zero: são indefinidos. (...) A 'simplificação' de que as taxas de lucro são iguais, ou de que a oferta iguala a demanda, é de um tipo diferente. Simplifica restringindo, não removendo restrições [Freeman 1996b: 275 , nota 1$]$.

Assim, segundo a concepção das "aproximações sucessivas", o nível mais abstrato é apenas uma construção mental, não existe na realidade; a aproximação do real cresce à medida que vamos suprimindo hipóteses simplificadoras. De acordo com o método de Marx, ao contrário, o que construímos no nosso conhecimento como nível abstrato são aspectos da realidade, são conceitos que têm uma correspondência real — é a realidade tomada de modo mais simplificado, isto é, apenas em suas determinações mais fundamentais. O nível mais concreto inclui estes aspectos, não os exclui como no método das "aproximações sucessivas”.

\section{4 - A QUESTÃO DA "PROVA DO VALOR"}

\footnotetext{
${ }^{48}$ As afirmações de que no Livro I Marx desconsidera os preços das mercadorias individuais e de que os capitais individuais não entram na análise são corretas apenas no sentido de que, dado o foco no "capital em geral”, estes aspectos são secundários. De fato, ao mencionar, no Capítulo III, que os preços podem divergir dos valores (como vimos na subseção 1.3.1), de uma forma aliás incompatível com o "método das aproximações sucessivas", Marx está falando, naturalmente, do preço de mercadorias individuais. Sob a limitação da interpretação de Moseley desta questão, ver a nota 32 do Capítulo 4, p. 177.
} 
Desde Böhm-Bawerk [1974; publicado originalmente em alemão em 1896], Marx tem sido acusado de tentar provar a existência do valor por uma "dedução lógica-dialética" inconsistente, nas primeiras páginas de $O$ Capital. No entanto, a idéia de que Marx quer “provar" alguma coisa pelo desenvolvimento lógico dos conceitos é absurda; um tal método seria considerado por ele idealista. Seu método, ao contrário, procura explicar a lógica presente na realidade, e reproduzi-la conceitualmente; seus argumentos lógicos são uma maneira de analisar determinadas formas sociais para extrair suas conseqüências.

Os aspectos centrais da "prova do valor" de Marx são: a) a existência necessária de uma "substância comum" das mercadorias para que possa haver troca; b) o fato de que valor de uso e utilidade são do domínio da diversidade, não existem "em geral", e que "salta à vista que é precisamente a abstração de seus valores de uso que caracteriza a relação de troca das mercadorias" [O Capital I-I: 46-7; El Capital: I-I: 46]; c) que, por outro lado, podemos encontrar no trabalho abstrato uma realidade que constitui esta substância comum. Voltaremos ao conteúdo destes pontos (a noção de uma substância comum e a afirmação de que o trabalho abstrato tem uma existência real, enquanto a utilidade em geral não) no Capítulo 3. O importante aqui é ressaltar que nenhuma destas afirmações é uma dedução puramente lógica; em todas o ponto de partida são dados da realidade, da experiência concreta do capitalismo (e não da análise lógica de uma troca qualquer).

O Capital parte do capitalismo, de uma concepção geral de como ele funciona: indivíduos produzindo em sociedade, regulando sua atividade pelo mercado; troca de mercadorias tratadas como equivalentes; proporções de troca regulares, determinadas socialmente, e não subjetivamente. A atitude dos "agentes econômicos", tal como identificada por Marx a partir de sua percepção do capitalismo, é diferente da suposta pelos neoclássicos. Para estes, cada agente avalia simplesmente se prefere uma ou outra "cesta" de bens. Para Marx, cada agente procura avaliar quanto valem seus bens, para saber o que pode conseguir em troca. É fácil ver que a idéia de um valor formado objetivamente a partir de relações sociais é uma decorrência bastante direta deste tipo de percepção.

Isaac Rubin, referindo-se à argumentação sobre a existência de uma substância comum, também destaca que o ponto de partida de Marx é a estrutura concreta da economia mercantil:

(...) Marx não examina o caso individual de igualação de uma mercadoria a outra. O ponto de partida do argumento é a afirmação de um fato bem conhecido sobre a economia mer- 
cantil, o fato de que todas as mercadorias podem ser igualadas umas às outras, e o fato de que uma determinada mercadoria pode ser igualada a uma infinidade de outras mercadorias. Em outras palavras, o ponto de partida de todo o raciocínio de Marx é a estrutura concreta da economia mercantil, e não o método puramente lógico de comparação de duas mercadorias entre si [Rubin 1980, p. 124; Rubin 1974, p. 162].

Moishe Postone contrapõe outro argumento à afirmação de que Marx teria tentado “provar" o valor através de uma dedução lógica: o do caráter reflexivo, circular, da fundamentação das categorias em $O$ Capital:

A natureza do argumento marxiano, então, não deve ser o de uma dedução lógica: não começa com primeiros princípios inquestionáveis dos quais tudo o mais pode ser derivado, pois a forma mesma deste procedimento implica um ponto de vista trans-histórico. Antes, o argumento de Marx tem uma forma muito peculiar, reflexiva: o ponto de partida, a mercadoria - que é posta como o coração estruturante fundamental da formação social — é validado retroativamente pelo desenvolvimento do argumento, por sua capacidade de explicar as tendências do capitalismo, e por sua capacidade de dar conta de fenômenos que aparentemente contradizem a validade das categorias iniciais. Isto é, a categoria de mercadoria pressupõe a de capital e é validada pelo poder e rigor da análise do capitalismo para a qual serve de ponto de partida [Postone 1993, p. 141].

Marx havia advertido para a possibilidade de seu método ser interpretado equivocadamente como uma construção a partir de conceitos apriorísticos. Na passagem do Posfácio à segunda edição do Livro I de $O$ Capital citada anteriormente, ele observa que, se a pesquisa conseguir "captar detalhadamente a matéria, analisar as suas várias formas de evolução e rastrear sua conexão íntima", a exposição poderá reproduzir "adequadamente o movimento real" e "refletir idealmente a vida deste objeto"; então é possível que pareça ser "uma construção a priori" [O Capital I-I, p. 26; El Capital I-I, p. 19].

Também nas Notas sobre Wagner Marx critica muito claramente o método de "encadear conceitos" dos professores alemães (referindo-se em primeiro lugar ao próprio Wagner); e afirma partir da mercadoria como uma forma social concreta. Assim, os conceitos abstratos iniciais são encontrados a partir da análise de uma forma social concreta; e esta relação com o concreto se mantém ao longo de toda a exposição. A progressão dialética dos conceitos tem sempre base na apreensão de aspectos da realidade; é sempre uma maneira de o "cérebro pensante" se "apropria[r] do mundo do único modo que lhe é possível" [Introdução / 1857, p. 15]. 


\section{CAPÍtulo 3 - Duplo CARÁter do TRABalho E SUbSTÂNCIA do VALOR}

\section{1 - INTRODUÇÃO}

Este capítulo fundamenta a primeira parte da exposição realizada no Capítulo 1, isto é, uma interpretação do percurso teórico de Marx da mercadoria ao capital, e desenvolve alguns de seus aspectos, retomando a argumentação que está no centro desta tese.

A seção 3.2 trata do duplo caráter do trabalho produtor de mercadorias. A subseção 3.2.1 destaca a importância decisiva atribuída por Marx a esta questão. As subseções 3.2.2 a 3.2.6 especificam diversas razões para isto: o duplo caráter do trabalho permite apreender a especificidade histórica da economia capitalista; torna possível identificar uma substância social do valor; permite captar a dinâmica contraditória da economia capitalista; justifica o vínculo exclusivo entre valor e trabalho; e permite tratar adequadamente diversas questões "técnicas" da teoria do valor.

A seção 3.3 discute o conceito de trabalho abstrato. A subseção 3.3.1 procura identificar as condições que ele deve atender para justificar a coerência da teoria marxista do valor, e comenta criticamente algumas das interpretações desta questão. A subseção 3.3.2 analisa a formação do trabalho abstrato a partir da generalização da produção de mercadorias; as subseções de 3.3.3 a 3.3.6 discutem a complexa questão da determinação quantitativa do trabalho abstrato e, portanto, do valor das mercadorias.

A subseção 3.3.7 propõe uma definição: trabalho abstrato é o trabalho reduzido a puro dispêndio produtivo de cérebro, músculos, nervos, mãos etc. humanos, redução tornada real à medida que a generalização da produção mercantil (da economia capitalista) desenvolve a indiferença com relação ao conteúdo concreto do trabalho. A subseção 3.3.8 enfatiza que a determinação quantitativa do trabalho abstrato é realizada já no momento da produção, questão central para o argumento desta tese, e a subseção 3.3.9 justifica a referência a trabalho abstrato.

A quarta seção trata da natureza do trabalho abstrato como substância social do valor; apresenta vantagens conceituais e analíticas desta abordagem, discute e avalia algu- 
mas das críticas que lhe foram feitas; e conclui com uma referência aos argumentos empíricos em seu favor.

\section{2 - O DUPLO CARÁTER DO TRABALHO}

\subsection{1 - O "resultado crítico final de século e meio de pesquisas"}

Marx destacou repetidamente a questão do duplo caráter do trabalho que produz mercadorias como a questão central para a compreensão da Economia Política e para sua crítica. Provavelmente, ele o fez pela primeira vez em Para a Crítica da Economia Política. Após expor o tema do trabalho abstrato já na primeira parte do Capítulo I, “A mercadoria”, começou o anexo deste capítulo, “Apontamentos históricos para a análise da mercadoria", dizendo que este "é o resultado crítico final de mais de século e meio de pesquisas da Economia Política clássica":

A análise da mercadoria através da redução desta a um trabalho de dupla forma (de um lado, a redução) do valor de uso a um trabalho real, isto é, à atividade produtiva aplicada a um fim, de outro, do valor de troca a tempo de trabalho, ou seja, a trabalho social igual, é o resultado crítico final de mais de século e meio de pesquisas da Economia Política clássica [Para a Crítica da Economia Política, p. 47].

Na seqüência, todo o anexo ressalta a importância desta distinção.

O Capítulo I do Livro I de O Capital voltou a destacar este ponto:

Essa natureza dupla do trabalho contido na mercadoria foi criticamente demonstrada pela primeira vez por mim. Como esse é o ponto crucial em torno do qual gira a compreensão da Economia Política, ele deve ser examinado mais de perto [O Capital I-I: 49; El Capital I-I, p. 51].

Em uma carta a Engels, escrita na época da publicação da primeira edição do Livro I de $O$ Capital, Marx foi igualmente enfático:

(...) [O] que há de melhor no meu livro é: 1- (e é sobre isto que repousa toda a inteligência dos fatos) o destaque, desde o primeiro capítulo, do caráter duplo do trabalho, conforme ele se expressa em valor de uso ou em valor de troca; 2 (...) [Marx a Engels, 24/08/1867; Marx et Engels 1964, p. 174].

Em outra carta a Engels, disse que "este é de fato o segredo de toda a concepção crítica": 
Uma coisa bem simples escapou a todos os economistas sem exceção, é que se a mercadoria tem um duplo caráter de valor de uso e de valor de troca, é necessário que o trabalho representado nesta mercadoria possua este duplo caráter ele também; enquanto que a mera análise do trabalho sans phrase, tal como a encontramos em Smith, Ricardo, etc., se choca por toda parte fatalmente com problemas inexplicáveis. É este de fato todo o segredo da concepção crítica [Marx a Engels, 08/01/1868; Marx et Engels 1964, p. 195].

Também em seu último escrito sobre O Capital — as Notas sobre Wagner - Marx voltou a enfatizar o duplo caráter do trabalho:

Por outro lado, o vir obscuros não se deu conta de que, já ao fazer a análise da mercadoria, eu não me detenho na dupla modalidade sob a qual se apresenta, mas passo imediatamente a demonstrar que nesta dupla modalidade da mercadoria se manifesta o duplo caráter do trabalho de que aquela é produto; do trabalho útil, isto é, dos modi concretos dos distintos trabalhos que criam valores de uso e do trabalho abstrato, do trabalho como gasto de força de trabalho, qualquer que seja o modo "útil" como se gaste (...) [Notas sobre Wagner, p. $50]$.

Seria difícil destacar mais a importância desta questão do que Marx fez nestas passagens. No entanto, ele próprio não a explicitou sempre ao longo de $O$ Capital, como seria de se esperar ${ }^{1}$, embora sem dúvida ela esteja presente ao longo de todo o livro. As interpretações posteriores da teoria econômica de Marx quase sempre não lhe dão um lugar central; a outra questão citada por ele como uma contribuição fundamental sua - o tratamento da mais-valia em geral antes das suas formas particulares — tem sua importância muito mais lembrada, embora ele a tivesse colocado em segundo lugar.

O destaque do trabalho abstrato e da forma do valor, tal como é feito por Isaac Rubin e por diversos economistas a partir dos anos 1970, muitos dos quais se inspiram na sua obra, é certamente uma maneira de enfatizar a importância do duplo caráter do traba1 ho ${ }^{2}$; mas ele não chama a atenção para alguns dos aspectos mais importantes deste duplo caráter, relacionados com a interação contraditória das duas naturezas do trabalho.

\footnotetext{
${ }^{1}$ Talvez Marx julgasse já ter deixado a questão suficientemente clara. Neste caso, equivocou-se.

${ }^{2}$ Dois exemplos de autores que privilegiam a discussão da forma do valor e enfatizam a importância do duplo caráter do trabalho: a) Jean Cartelier [1981]; sua conclusão, "Marx y la crítica de la economia política", destaca a importância do duplo caráter do trabalho na distinção entre a economia de Marx e a Economia Política Clássica. Mas sua interpretação althusseriana parece particularmente desfavorável para a extra-
} 
Apenas alguns autores colocam esta questão de forma explícita no centro de sua interpretação. Um deles é Henrik Grossmann, em Marx, l'Economie Politique Classique et le Problème de la Dynamique [Grossmann 1975; edição original em alemão de 1940]; seguindo os comentários de Marx citados, ele afirma (e fundamenta) que a questão do duplo caráter do trabalho tem o lugar central na distinção entre a economia marxista e a Economia Política Clássica. Outro autor que atribui a esta questão uma importância primordial é Moishe Postone [Postone 1978 e Postone 1993]; para ele, uma das debilidades mais importantes do "marxismo tradicional” é justamente desprezá-la, e a partir daí tratar o trabalho como uma categoria trans-histórica.

Na exposição das categorias centrais da economia de Marx, realizada no Capítulo 1, já chamamos a atenção para a importância do duplo caráter do trabalho produtor de mercadorias. É preciso, no entanto, fazer aqui um exame mais detalhado das razões disto.

\subsection{2 — Dualidade das categorias econômicas e especificidade histórica}

Há uma maneira trivial de entender o trabalho abstrato, e a partir daí de justificar a importância do duplo caráter do trabalho, que é lembrar que o trabalho que produz as distintas mercadorias, para ser comparado quantitativamente, tem de ser tomado como homogêneo, igual. Esta razão certamente não justificaria toda a ênfase de Marx nesta questão; além do mais, não pode haver muita dúvida de que os antecessores de Marx, em particular Ricardo, pensavam no trabalho humano como uma coisa homogênea, e é por isso que não viam problemas em quantificá-lo e compará-lo.

De fato, a originalidade de Marx começa precisamente na direção oposta - a de problematizar o caráter homogêneo do trabalho. Como vimos na subseção 1.2.1, após concluir que o valor, o "algo comum" que os valores de troca exprimem, só pode vir da abstração dos valores de uso, e passar então à análise do trabalho, Marx constata que também o caráter material, concreto, do trabalho deve ser abstraído para que cheguemos a "igual trabalho humano", a "trabalho humano abstrato" [O Capital I-I, pp. 46-7; El Capital I-I,

ção das conseqüências mais interessantes desta ênfase; e o pensamento de Cartelier, depois deste livro, evoluiu em outra direção. b) Geert Reuten e Michael Williams [Reuten e Williams 1989, Reuten 1995, especialmente pp. 105-6]. 
pp. 46-7]. A existência deste caráter do trabalho deve ser explicada, e é um resultado histórico, como vimos na seqüência da seção 1.2. Não se trata de algo trivial.

A partir daí, Marx construiu seu sistema teórico em torno de categorias econômicas duais: trabalho concreto e trabalho abstrato, valor de uso e valor, riqueza material (real) e riqueza abstrata (em valor), processo material de produção e processo de valorização, etc. As duplicidades das categorias são em geral fundamentais em todo $O$ Capital, e isto é fácil de ser mostrado. A questão que nos ocupa pode então ser posta da seguinte maneira: por que enfatizar o duplo caráter do trabalho, e não o duplo caráter da mercadoria, que foi como esta dualidade apareceu pela primeira vez? O duplo caráter da mercadoria, isto é, a contraposição entre valor de uso e valor (de troca), já era conhecido pela Economia Política clássica. O que foi acrescentado quando o duplo caráter do trabalho que produz mercadorias foi notado?

Uma primeira explicação é bastante clara: sem o duplo caráter do trabalho, o duplo caráter da mercadoria fica um tanto esvaziado, torna-se quase trivial ${ }^{3}$. A distinção trabalho concreto $x$ trabalho abstrato permite completar e dar coerência à distinção valor de uso $x$ valor. Mais significativo ainda, com o duplo caráter do trabalho Marx vai à fonte do duplo caráter da mercadoria. A existência do valor se explica pelas peculiaridades do trabalho na economia capitalista, isto é, pelo desenvolvimento do caráter abstrato do trabalho portanto, pela duplicação do trabalho. Além disto, a afirmação da dupla natureza assumida pelo trabalho quando produz mercadorias permite fundar igualmente a contraposição entre riqueza material e riqueza capitalista, entre produção de valores de uso e produção de valor. Esta última não pode ser tratada a partir apenas do duplo caráter da mercadoria, e o mesmo acontece com a duplicidade de outras categorias econômicas.

Em resumo: é a afirmação do duplo caráter do trabalho produtor de mercadorias que permite passar de uma questão quase trivial (o duplo caráter da mercadoria) para um sistema teórico construído a partir da duplicidade geral das categorias econômicas.

\footnotetext{
${ }^{3}$ A qualificação "quase" é necessária. Embora esta dualidade fosse muito clara para a Economia Política clássica, e possamos entender que ela pertence praticamente ao senso comum — uma coisa é o interesse que podemos ter em um produto se queremos consumi-lo, outra coisa é o interesse se queremos vendê-lo —, a economia neoclássica se assenta, entre outros aspectos, na sua negação.
} 
Isto nos leva diretamente a outra questão fundamental: a duplicidade do trabalho na economia capitalista consiste na distinção entre, de um lado, o trabalho enquanto atividade concreta e útil, existente em todas as formas de sociedade e, de outro, o caráter social específico e as funções que o trabalho assume na economia mercantil-capitalista, o que se desdobra na distinção entre características técnicas e forma social do trabalho, no desdobramento das necessidades do processo de produção capitalista em necessidades técnicas e necessidades ligadas especificamente à forma capitalista. Este último ponto se desdobra no duplo caráter do processo de gestão no capitalismo: ele tem um aspecto de coordenação, necessário dado o caráter coletivo do trabalho, que decorre portanto de necessidades técnicas do processo de produção; e um aspecto ligado às necessidades de valorização, específico ao modo capitalista de produção ${ }^{4}$.

É a partir do caráter social específico do trabalho na economia mercantil-capitalista que se desenvolvem o fetichismo da mercadoria e seus derivados, que a economia capitalista se distingue como uma forma social historicamente peculiar e as suas categorias como historicamente peculiares ${ }^{5}$. Além disso, a compreensão de que o modo de produção capitalista tem limites históricos determináveis, e a afirmação daí decorrente do caráter histórico das categorias da economia mercantil, são a chave para o projeto de crítica da economia política.

\subsection{3 - Substância social, dinheiro e capital}

Como vimos no Capítulo 1, é a análise qualitativa do valor de troca que leva à descoberta da existência do valor, e daí ao duplo caráter do trabalho produtor de mercadorias e à existência, na economia capitalista, de uma substância do valor, o trabalho abstrato. Por outro lado, o fato de o valor ter uma substância, o trabalho abstrato, permite explicar o

\footnotetext{
${ }^{4}$ Henryk Grossmann [1975, pp. 69-70] chamou a atenção para este ponto.

${ }^{5}$ Moishe Postone amplia a importância do duplo caráter do trabalho para a compreensão do caráter histórico da economia capitalista. Fala da existência de uma necessidade histórica, de uma lógica histórica, próprias à economia capitalista, e vincula-as ao duplo caráter das estruturas do capitalismo: "Situando o fundamento material da necessidade histórica, de uma lógica histórica, no ‘duplo caráter' das estruturas alienadas características do capitalismo (a mercadoria como valor e valor de uso, o processo de produção como processo de valorização e processo de trabalho), Marx rompe com qualquer princípio único trans-histórico da história humana” [Postone 1978, in: Wood III 1988, p. 564].
} 
dinheiro como sua concretização material, e o capital como esta substância em movimento. Tudo isto foi já enfatizado na seção 1.5 , do mesmo modo que o lugar central que o duplo caráter do trabalho ocupa na estrutura desta conceituação, e não é necessário repeti-lo aqui.

Na seção 3.4 voltaremos à discussão da questão da constituição de uma substância do valor a partir do desenvolvimento do caráter abstrato do trabalho.

\subsection{4 - A interação contraditória trabalho concreto $\mathrm{x}$ trabalho abstrato}

Marx conclui a segunda parte do Capítulo I do Livro I, em que amplia o exame do duplo caráter do trabalho representado nas mercadorias, contrapondo a dinâmica divergente da produção de valores de uso - de riqueza material - e da produção de valor de riqueza abstrata - , a partir do desenvolvimento da produtividade do trabalho. Esta dinâmica decorre do duplo caráter do trabalho ${ }^{6}$ :

Força produtiva é sempre, naturalmente, força produtiva de trabalho útil concreto, e determina apenas, de fato, o grau de eficácia de uma atividade produtiva (...); uma mudança de força produtiva não afeta, em si e para si, de modo algum o trabalho representado no valor. Como a força produtiva pertence à forma concreta útil de trabalho, já não pode esta, naturalmente, afetar o trabalho, tão logo faça-se abstração de sua forma concreta útil [O Capital I-I, p. 53; El Capital I-I, pp. 56-7].

Marx retomou este argumento e o completou no Capítulo V do Livro I (como resumimos na subseção 1.4.3 deste trabalho), com a explicitação de que a distinção trabalho concreto x trabalho abstrato leva à duplicação do processo produtivo em processo de trabalho material e processo de valorização, e portanto separa a produção de valores de uso, ou seja, a produtividade física, da produção de valor.

O fato de o valor ser medido pelo tempo de trabalho socialmente necessário - o que decorre, como vimos no Capítulo 1, subseção 1.2.3, do caráter especificamente social do trabalho produtor de mercadorias - faz que a melhora da produtividade reduza a produção de valor por unidade do produto. Há, portanto, uma dinâmica divergente típica da economia capitalista, decorrente da interação contraditória do trabalho concreto e do trabalho abstrato; a quantidade de trabalho abstrato (valor) e a quantidade de trabalho con-

\footnotetext{
${ }^{6}$ Esta passagem já foi citada na subseção 1.2.1.
} 
creto, ou melhor, os seus efeitos, podem mover-se de modo diferente; o mesmo acontece, portanto, com a produção de riqueza material e de valor ${ }^{7}$.

Certamente a referência de Marx: “(...) a mera análise do trabalho sans phrase, tal como a encontramos em Smith, Ricardo, etc., se choca por toda parte fatalmente com problemas inexplicáveis”, que está carta a Engels de 08/01/1968 já citada acima, explica-se justamente porque sem a explicitação do duplo caráter do trabalho a dinâmica contraditória que decorre daí não pode ser percebida.

Este é um dos temas centrais do Capítulo 5. Adiantemos apenas, para reforçar a importância da interação contraditória do trabalho concreto e do trabalho abstrato, que esta questão é essencial para a compreensão do funcionamento da lei do valor, da concorrência entre os capitais, da lei da tendência decrescente da taxa de lucro, das crises (da razão pela qual o progresso técnico não apenas não é suficiente para evitá-las, como pode até mesmo provocá-las) e do impacto contraditório mais geral do progresso técnico na economia capitalista.

\subsection{5 - Trabalho, valor, improdutividade do capital e mais-valia}

A distinção trabalho concreto $x$ trabalho abstrato é importante para justificar por que apenas o trabalho humano cria valor. A razão disto não é a atribuição de algum 'privilégio' injustificado ao trabalho na produção, ou uma desconsideração da contribuição dos meios de produção (ou da natureza) para a produtividade física ${ }^{8}$; são as características peculiares do trabalho na economia mercantil-capitalista. A questão não é, portanto, a importância geral do trabalho na atividade produtiva, e nem mesmo a importância geral do trabalho para a vida em sociedade, mas a sua forma histórica específica. Como diz Isaak Rubin, respondendo aos que questionam a posição "privilegiada" dada ao trabalho na teoria do valor-trabalho: “(...) a teoria do valor não trata do trabalho humano enquanto fator

\footnotetext{
7 Tanto Henryk Grossmann [1975] quanto Moishe Postone [1993] dão a este aspecto um lugar central na sua descrição da dinâmica do capitalismo.

${ }^{8}$ De fato, Marx enfatizou o oposto, tanto quando chamou a atenção para que o aumento da força produtiva intensifica a produção de valores de uso (como foi comentado na subseção anterior), como quando, apoiando-se em William Petty, disse que o "trabalho não é a única fonte dos valores de uso que produz, da riqueza material' [O Capital I-I, p. 50-1; El Capital I-I, p. 53].
} 
técnico de produção, mas da atividade de trabalho das pessoas como a base da vida na sociedade e das formas sociais sob as quais este é realizado" [Rubin 1980, p. 97; grifo JM].

Esta questão é freqüentemente confundida, mesmo por bons conhecedores de Marx. Maurice Dobb, por exemplo, em Economía Política y Capitalismo, discute as razões da superioridade da "teoria-custo do valor baseada no trabalho", e diz o seguinte:

Por que a teoria-custo do valor baseada no trabalho, que é reconhecidamente apenas um dos fatores de produção da riqueza, haveria de ter uma categoria superior a qualquer outra teoria-custo que se possa imaginar, por exemplo, a que toma o capital ou a terra como a quantidade determinante? (...) Em última análise, esta é, certamente, uma questão prática e não formal. A exatitude de um princípio econômico consiste em que, não obstante fazer abstração de certos aspectos do problema, o faz para centrar a atenção nas características fundamentais desta parte do mundo real à qual pretende-se aplicar a teoria.

$(\ldots)$

(...) Que o trabalho constitui um custo em um sentido único é, naturalmente, um suposto; porém um suposto nascido de um ponto de vista particular acerca do que é a essência do problema econômico. (...) O essencial do problema econômico, de acordo com esta teoria e com a opinião tradicional, consiste na luta do homem com a natureza para arrancar-lhe o sustento segundo as diferentes formas de produção através das diferentes etapas da história. Como disse Petty, o trabalho é o pai e a natureza é a mãe da riqueza ${ }^{9}$. O contraste entre a atividade humana (dotada de grande significação como a iniciadora e a geradora da mudança e do incremento) e o processo da natureza é fundamental para esta relação. Se quando falamos do problema econômico nos referimos não a seu caráter formal, senão a seu conteúdo real, e tentamos assinalar um elemento comum a diversas formas que a luta econômica adotou nas diferentes etapas da história, é difícil encontrar um princípio que não inclua como elemento fundamental esta relação sempre cambiante entre o trabalho e a natureza, e o contraste fundamental entre estes dois fatores. E se tratamos de dar uma expressão quantitativa a esta relação — o domínio da natureza pelo homem — é difícil achar outra noção simples que não seja o gasto de energias humanas (em um determinado estado da sociedade) como requisito para produzir certo resultado [Dobb 1945, pp. 19-20].

\footnotetext{
${ }^{9}$ Notemos que Dobb não faz a mesma distinção de Marx entre riqueza material (valor de uso) e riqueza abstrata (valor), razão pela qual lhe escapa o sentido que Marx dá a esta observação de Petty.
} 
Como vemos, Dobb busca o fundamento do vínculo entre trabalho e valor nas propriedades antropológicas do trabalho, nas propriedades do trabalho comuns às diversas etapas da história, no domínio do gênero humano sobre a natureza. Um pouco adiante, sugere não haver uma diferença fundamental entre a teoria de Marx e a de Ricardo, ao comentar que "[o] trabalho concebido objetivamente como o produto da energia humana, era a medida e a essência da 'dificuldade ou facilidade da produção' de que falava Ricardo” [p. 21]. A limitação fundamental de seu argumento é não relacionar o "sentido único" em que o trabalho constitui um "custo" com o duplo caráter do trabalho na economia mercantilcapitalista, e é isto que o leva a buscar justificativas na história humana em geral.

Simon Mohun, que em muitos aspectos diverge fundamentalmente das concepções de Dobb, segue um curso semelhante. Propõe a questão: "Por que o valor é tempo de trabalho, e que espécie de tempo de trabalho é ele?" [Mohun, 1994, p. 214], e responde da seguinte maneira:

[Esta] questão é am alguns aspectos a mais fácil ${ }^{10}$. O valor é tempo de trabalho por uma ontologia essencialista que o que define a existência humana como especificamente humana é a atividade produtiva com finalidade. O materialismo histórico de Marx interpretou tal atividade em termos de sua habilidade de transformar o meio-ambiente no qual se situa, transformação que muda os próprios produtores e portanto muda sua atividade produtiva. Este foco no trabalho humano imediatamente invoca uma teoria do valor trabalho [Mohun 1994, p. 215-6].

Como diz Moishe Postone:

(...) [M]uitos argumentos referentes à análise de Marx da exclusividade [uniqueness] do trabalho como a fonte do valor não se dão conta de sua distinção entre 'riqueza real' (ou 'riqueza material') e valor. A 'teoria do valor-trabalho de Marx', entretanto, não é uma teoria das propriedades exclusivas [únicas, unique] do trabalho em geral, mas é uma análise da especificidade histórica do valor como uma forma de riqueza, e do trabalho que supostamente o constitui [Postone 1993, pp. 25-6].

Naturalmente, o argumento de que o capital é improdutivo deve ser interpretado a partir da discussão de por que o valor vem apenas do trabalho. Não se trata de uma improdutividade física dos meios de produção, o que seria absurdo, e foi negado explicitamente

\footnotetext{
${ }^{10}$ Seria mais prudente não falar em “questão mais fácil”.
} 
por Marx ${ }^{11}$, mas simplesmente da incapacidade de criar valor novo ${ }^{12}$. Do mesmo modo, esta é a explicação da afirmação de que o capital (entendido como meios de produção) não gera para si uma remuneração a partir dos seus "serviços", mas apenas se apropria da maisvalia (de mais-valor), ou seja, de mais-trabalho, "trabalho não pago". O trabalho "não pago" é o trabalho vivo abstrato; a força física de trabalho é paga pelo salário.

A existência da mais-valia vincula-se, portanto, ao duplo caráter do trabalho. Em primeiro lugar, pela criação de valor exclusivamente pelo trabalho humano; em segundo lugar, porque a possibilidade de geração de um excedente depende do duplo caráter da mercadoria força de trabalho, ou seja, da distinção entre o valor de uso da força de trabalho (o trabalho vivo) e seu valor.

Em terceiro lugar, a existência de um excedente só é possível se o valor criado pelo trabalhador for superior ao valor da sua força de trabalho. Esta condição pode ser garantida a partir da distinção entre produção de valor e produção de valores de uso - que decorre do duplo caráter do trabalho: como o valor da força de trabalho cai quando aumenta a produção de valores de uso, ele pode ser reduzido com o aumento da produtividade física até tornar-se inferior ao valor criado pelo trabalhador. Daí se abre também a possibilidade de produção de mais-valia relativa.

\subsection{6 - Aspectos 'técnicos' vinculados ao duplo caráter do trabalho}

Finalmente, há diversos aspectos 'técnicos' decorrentes do duplo caráter do traba1ho. Alguns deles se ligam ao duplo caráter do trabalho através do duplo caráter da mercadoria.

1. Como vimos, a distinção 'técnica' fundamental entre trabalho e força de trabalho é uma expressão do duplo caráter da mercadoria força de trabalho.

2. O duplo caráter do trabalho permite explicar a conservação do valor dos meios de produção pela sua transferência para as mercadorias produzidas (realizada

\footnotetext{
${ }^{11}$ Ver nota 8, acima.

${ }^{12}$ Como vimos na seção 3.2.4, o aumento da produtividade reduz o valor unitário das mercadorias; há maior produção de valores de uso sem que aumente o valor produzido por espaço de tempo.
} 
pelo trabalho enquanto trabalho concreto ${ }^{13}$ ), ao mesmo tempo em que é gerado valor novo (pela objetivação de trabalho abstrato).

3. O duplo caráter do trabalho reflete-se portanto na distinção entre capital constante (trabalho morto, cujo valor é conservado pelo trabalho concreto) e capital variável (que se troca por trabalho vivo que se objetiva como trabalho abstrato).

4. O duplo caráter do trabalho vincula-se, portanto, à categoria de composição orgânica do capital $^{14}$. Ela é uma síntese entre a composição técnica (aspecto valor de uso) e composição em valor (capital constante adiantado/capital variável). A tendência de que a composição orgânica cresça (base da lei da tendência decrescente da taxa de lucros) é uma expressão da dinâmica divergente do trabalho concreto e do trabalho abstrato, como vimos na subseção 3.2.4.

\section{3 - O TRABALHO ABSTRATO}

\subsection{1 - $O$ que se exige do conceito}

O conceito de trabalho abstrato fundamenta a determinação da quantidade do valor pelo trabalho, e permite identificar a substância, o conteúdo do valor; dizendo de outra maneira, dá a base para tratar o valor como substância, e para afirmar sua existência real. Isto define o que é exigido deste conceito: o trabalho abstrato tem de ser algo real; não pode ser uma mera generalização mental, pois neste caso o próprio valor seria reduzido a uma construção mental.

Como vimos no Capítulo 1, subseção 1.2.1, Marx argumentou que a utilidade em geral somente pode ser uma generalização sem existência própria - existe apenas nos valores de uso singulares, e esta é uma razão de fundo para rejeitá-la como possível fundamento do valor. Ele não afastou a utilidade em geral com base em puros argumentos lógicos, mas porque ela não tem realidade [Kay 1979, pp. 52-4]. Trata-se, portanto, de um ar-

\footnotetext{
${ }^{13}$ Marx menciona esta questão no Capítulo VI do Livro I. Para constatarmos que "conservar o valor" é propriedade do trabalho concreto, basta lembrar que quanto maior for a produtividade, mais valor se conservará em cada intervalo de tempo (já que mais meios de produção serão processados).

${ }^{14}$ Ponto para o qual Grossmann chamou a atenção [Grossmann 1975, pp. 71-2].
} 
gumento empírico, que podemos exemplificar da seguinte maneira: é impossível usar alimentos sólidos para matar a sede; no meio de um deserto, não há quantidade de alimentos sólidos que possa substituir a água. Se houvesse uma utilidade em geral, de modo que as utilidades particulares se distinguiriam apenas por sua quantidade, isto seria possível. Por outro lado, como valores ${ }^{15}$, alimentos podem ser substituídos por água. É possível explicar este caráter de valores através do trabalho, e portanto argumentar que o trabalho em geral tem realidade?

Segundo Marx, sim, é possível: o trabalho abstrato é o trabalho que tem realidade como generalidade. No entanto, as "leituras vulgares" deste conceito não fundamentam esta afirmação. Ruy Fausto as caracteriza da seguinte maneira:

As leituras vulgares interpretavam a abstração que constitui o trabalho abstrato e o valor como se se tratasse de uma simples generalização: nos trabalhos (concretos) do carpinteiro, do construtor, do fiandeiro etc, far-se-ia abstração do que é próprio a cada um deles, da particularidade de cada trabalho, e se obteria assim, generalizando os resíduos, a noção de trabalho abstrato. Esta interpretação nos condena à alternativa: ou o trabalho abstrato não é senão uma construção subjetiva (só haveria no real diferentes trabalhos específicos; constrói-se pelo pensamento, através do procedimento clássico da generalização, a noção de trabalho abstrato, de trabalho em geral); ou esta generalização é real, mas nesse caso - se o trabalho abstrato não é senão uma simples generalidade, obtida ignorando as particularidades dos trabalhos - esta realidade só poderia ser constituída pelas características fisiológicas comuns a todos os trabalhos [Fausto, 1983c, p. 123, nota 4].

Nem como generalização mental, nem como características fisiológicas comuns, o trabalho abstrato consegue cumprir o que lhe é exigido.

O pioneiro em uma "leitura não vulgar do trabalho abstrato" foi Isaac Rubin ${ }^{16}$, desde os anos 1920. A ênfase neste conceito, e na questão da forma do valor, seguindo o caminho aberto por ele, foi um dos temas centrais da renovação dos estudos sobre a teoria do valor de Marx a partir dos anos 70 do século XX; fala-se freqüentemente, inclusive, em

\footnotetext{
${ }^{15} \mathrm{O}$ que supõe, naturalmente, que se trate de bens produzidos como mercadorias.

${ }^{16}$ Rudolf Hilferding, na sua resposta a Böhm-Bawerk [Hilferding 1974, originalmente publicada em 1904], pode ser considerado um precursor.
} 
uma "escola Rubin", ou em "escola do trabalho abstrato". A abordagem desta escola se contrapôs à então predominante, chamada de abordagem do "trabalho incorporado".

Esta abordagem mais tradicional tem em Maurice Dobb [1945, 1975], Paul Sweezy [1967] e Ronald Meek [1973] seus representantes mais influentes. A "escola do trabalho abstrato" argumentou que estes autores colocam a questão da forma do valor — da forma social que faz o trabalho se representar como valor - num segundo plano, e tendem a ver o trabalho abstrato simplesmente como o resultado de uma generalização ou homogeneização (por meio de uma abstração) do trabalho concreto; ficam, portanto, em má posição para fundamentar a realidade do trabalho abstrato - e do valor. A importância da forma do valor sendo um ponto chave na distinção entre Marx e a Economia Política clássica $[O$ Capital I-I, p, 76, nota 32; El Capital I-I, p. 98, nota 32], estes autores aproximam Marx de Ricardo e tendem a incluí-lo entre os economistas clássicos; desta maneira, se aproximam também da abordagem sraffiana ou neo-ricardiana, coerentemente saudada por alguns deles como a reabilitação da economia clássica e de Marx [Meek 1967b; Dobb 1975, especialmente pp. 279-289].

Enfatizamos desde a Introdução deste trabalho que a obra de Rubin é uma das sua referências mais importantes; além disto, vários pontos da argumentação da "escola do trabalho abstrato" ${ }^{17}$ devem ser aceitos. No entanto, o tratamento dado pelo próprio Rubin ao trabalho abstrato tem algumas insuficiências, como veremos; e muitos dos autores que o seguiram (ou se propuseram a ir além dele) interpretaram sua ênfase na idéia de que o trabalho abstrato é desenvolvido pelo processo de troca de uma maneira que agravou estas insuficiências ${ }^{18}$.

\footnotetext{
${ }^{17}$ Geert Reuten e Michael Williams [Reuten e Williams 1989, pp. 64-5; Reuten 1993 e Reuten 1995, p. 106] distinguem duas abordagens entre estes autores. Falam de uma linha de interpretação centrada no "trabalho abstrato incorporado" e de uma "teoria da forma do trabalho abstrato" (form theory of abstract-labor) ou “teoria da forma valor" (value-form theory). A primeira seria mais próxima da interpretação de Marx [Reuten 1993, p. 99, p. 103], enquanto a segunda (com a qual se identificam) buscaria uma superação crítica da teoria de Marx.

${ }^{18}$ Dois bons balanços desta posição são feitos por: a) Michel de Vroey [1985]; De Vroey retrata neste artigo sua própria evolução, já que passou de um defensor desta interpretação para uma posição cética, à medida que se convenceu de suas dificuldades. b) Pichit Likitkijsomboon [1995], que faz uma crítica mais ampla desta concepção.
} 
Em primeiro lugar, a maneira pela qual contrapuseram o trabalho concreto ao trabalho abstrato levou muitas vezes à negação da determinação quantitativa do trabalho abstrato (e conseqüentemente do valor) na produção. Um exemplo patente desta posição é dado por John Weeks, que escreveu o seguinte:

(...) $[\mathrm{O}]$ conhecimento ou a percepção do tempo de trabalho é, em qualquer caso, irrelevante para a determinação dos valores de troca. Seja como for, se alguém conhece o tempo que um sapateiro leva para fazer um sapato, isto não fornece nenhuma informação adicional para a determinação do valor de troca dos sapatos além de saber que, de fato, sapatos estão sendo feitos [Weeks 1981, p. 28].

No mesmo sentido, Michael Eldred afirma enfaticamente que é preciso

(...) romper consistentemente com a determinação da magnitude do valor através do tempo de trabalho (...) [Eldred 1994b: 203].

A partir desta concepção, esta posição tende à afirmação de que o trabalho abstrato e o valor só se determinariam no momento da troca - em cada troca. Michel de Vroey resumiu a idéia central desta corrente teórica da seguinte maneira:

Nesta concepção o coração da teoria do valor não é mais a quantidade de trabalho incorporada em uma mercadoria mas a validação, isto é, o "salto perigoso" pelo qual o trabalho privado se transforma em trabalho social. Enquanto não há troca, o trabalho privado não é senão trabalho social potencial, uma pretensão a ser trabalho social [de Vroey 1985, p. 37].

Com isto, duvida-se de que o valor possa ser "uma entidade pré-mercado", como faz Geert Reuten [1993, p. 103]; e ele é confundido com o preço. Michael Eldred e Marnie Hanlon, por exemplo, são totalmente claros na identificação do valor com o preço de mercado:

É o preço, portanto, e não a duração, que mede com validade final a extensão com que o trabalho efetivado no processo imediato de produção de uma mercadoria é reconhecido para a totalidade das mercadorias industriais como valor de uma magnitude definida. Por esta razão, e em contraste com Marx, flutuações no preço devem ser vistas como flutuações na magnitude de valor das mercadorias [Eldred e Hanlon 1981, p. 39].

A partir de uma posição como esta, o que sobra da teoria do valor de Marx, que afirma expressamente que a magnitude do valor é determinada pelo tempo de trabalho, no momento da produção? A tendência nesta linha de interpretação, na verdade, é que a pró- 
pria referência a trabalho, concreto ou abstrato, perca o sentido. O valor é reduzido a uma categoria do mercado, a uma categoria da circulação apenas ${ }^{19}$.

Há ainda outro problema que aparece nesta linha de interpretação: a tendência a reduzir a realidade do trabalho abstrato à sua expressão no dinheiro, como fazem Eldred e Hanlon quando querem "romper consistentemente com a determinação da magnitude do valor através do tempo de trabalho" e afirmam que a determinação da quantidade de trabalho só pode ser feita no preço. Em seu artigo de 1984, Eldred diz que o trabalho abstrato "não tem existência substancial separada da forma do valor, o dinheiro" [Eldred 1994a, p. 200]. A mesma posição é defendida por Simon Mohun:

O trabalho abstrato como atividade laboral em geral não tem existência como tal; não tem substância [it is substanceless] fora de processos concretos de trabalho; seu caráter "puramente social" significa que "ele só pode aparecer na relação social entre mercadoria e mercadoria” [Marx, Capital I, Penguin, p. 139; O Capital I-I, p. 54 ${ }^{20}$ ]. Tal relação requer o desenvolvimento do dinheiro. Logo, o trabalho abstrato é a substância do valor precisamente na medida em que toma a forma de dinheiro. Esta não é uma abstração mental, mas sim uma abstração real, pois o dinheiro tem existência fora das mercadorias [Mohun 1994, p. 222].

Mohun interpreta incorretamente a posição de Marx: o que este diz é que o trabalho abstrato só aparece na relação entre as mercadorias, o que leva, como foi estudado no item sobre a forma do valor, à sua expressão em dinheiro. Além disso, o dinheiro é necessário para que a dimensão abstrata do trabalho se desenvolva, como vimos no Capítulo 1, subse-

\footnotetext{
${ }^{19}$ Moishe Postone aponta que a confusão do valor com uma categoria da circulação é na verdade muito difundida no que ele chama de "marxismo tradicional” [Postone 1993, Capítulo 2]. A discussão deste ponto é um dos muitos méritos de seu livro.

${ }^{20}$ Foi mantido o texto da edição inglesa citada por Mohun. Na verdade, Marx está falando que o caráter objetivo das mercadorias como valores só pode aparecer na relação entre elas; é verdade, contudo, que isto equivale à objetividade do trabalho abstrato que está sendo discutida por Mohun. $\mathrm{O}$ argumento de Marx (completo), retraduzido da edição inglesa (que é mais clara que a brasileira neste ponto), é o seguinte: "Entretanto, recordemo-nos que as mercadorias possuem um caráter objetivo como valores apenas na medida em que são expressões de uma idêntica substância social, o trabalho humano, que seu caráter objetivo como valores é portanto puramente social. Daí segue de modo evidente que ele só pode aparecer na relação entre mercadoria e mercadoria""(Capital I, Penguin, pp. 138-9).
} 
ção 1.2.4. Sem o dinheiro, o trabalho abstrato não pode se desenvolver, e não aparece. Mas isto é diferente de dizer que o trabalho abstrato só é real, só existe, como dinheiro. Esta posição confunde o reconhecimento social do trabalho, realizado no momento da venda, com a determinação quantitativa do trabalho abstrato e do valor ${ }^{21}$.

Além disto, se não há uma dimensão abstrata quantitativa do trabalho anterior a cada troca, ou seja, a cada venda, e portanto com uma realidade anterior à da sua expressão em dinheiro, não pode existir alguma regularidade nas trocas. De fato, caímos em alguma versão da determinação do valor simplesmente pela oferta e procura.

Uma das motivações do desenvolvimento desta abordagem do trabalho abstrato foi a tentativa de enfrentar as dificuldades causadas pelo "problema da transformação"22. O que acontece, porém, é que o problema é eliminado (já que o valor coincide com o preço), mas não resolvido nos termos em que foi colocado.

Em síntese, é preciso cuidar para evitar uma interpretação do trabalho abstrato que exagera sua distinção do trabalho concreto, que o cinde do trabalho concreto até o ponto de levar à negação da possibilidade de quantificá-lo.

Ao contrário, uma das funções do conceito de trabalho abstrato é dar base para ancorar o valor em termos quantitativos (em primeiro lugar, como é evidente, por tornar os diversos trabalhos comensuráveis). É curioso que um conceito que tem tornar coerente a quantificação dos diversos gastos de trabalho como uma das suas razões tenha sido utilizado, inversamente, para negar esta possibilidade.

No restante desta seção tentaremos mostrar que é possível desenvolver o conceito de trabalho abstrato de modo a conseguir o que se exige dele, sem reproduzir as inconsistências apontadas acima.

\subsection{2 - Trabalho abstrato e generalização das trocas}

\footnotetext{
${ }^{21}$ Esta questão será discutida na subseção 3.3.6.

22 Esta motivação foi comentada, entre outros, por Guglielmo Carchedi [1993, p. 211] e Pichit Likitkijsomboon [1995, p. 94]. Examinaremos este problema no Capítulo 4.
} 
No Capítulo 1, nas subseções 1.2.3 e 1.2.4, tratamos da constituição do trabalho abstrato, com base fundamentalmente no item sobre o fetichismo da mercadoria do Capítulo I e no Capítulo II do Livro I de O Capital.

Em um trecho do item sobre o fetichismo da mercadoria, já citado no Capítulo 1, vimos que:

Ao equiparar seus produtos de diferentes espécies na troca, como valores, [os homens] equiparam seus diferentes trabalhos como trabalho humano. Não o sabem, mas o fazem $[O$ Capital I-I, p. 72; El Capital I-I, p. 90].

Esta passagem diz que o desenvolvimento do caráter abstrato do trabalho se faz a partir da igualação dos diversos trabalhos humanos, como resultado do processo de troca. A igualação dos diversos trabalhos humanos pressupõe a generalização da produção de mercadorias, e portanto da produção para a venda. Na medida em que o trabalho humano adquire este caráter, começa a se desenvolver sua dimensão abstrata.

Todo trabalho humano pode ser reduzido a um certo esforço fisiológico, certo "dispêndio produtivo de cérebro, músculos, nervos, mãos etc. humanos" [O Capital I-I, p. 51; El Capital I-I, p. 54]. Este é o ponto de partida do trabalho abstrato; mas a igualdade fisiológica é insuficiente para caracterizá-lo. A constituição do trabalho abstrato exige condições históricas específicas, dadas justamente pela generalização das trocas, pela generalização do trabalho para vender. Quando isto acontece, o trabalho interessa apenas na medida em que se expressa como valor das mercadorias; se estas vão ser vendidas, a seu produtor pouco importa seu valor de uso, e portanto pouco importa o caráter concreto, útil do trabalho que as produz.

Se raciocinamos de forma mais concreta, no contexto das relações no capitalismo, isto se torna mais claro. Do ponto de vista do trabalhador, que está interessado em comprar mercadorias com seu salário, qualquer tipo de trabalho serve para adquirir qualquer tipo de valor de uso. Para o capitalista, o trabalho é apenas um meio de gerar valor. Desenvolve-se portanto a indiferença com relação ao caráter concreto do trabalho.

Assim, com a generalização das trocas, a igualdade fisiológica dos trabalhos, o fato de eles poderem se reduzir a "dispêndio de força humana de trabalho" [O Capital I-I, p. 51; El Capital I-I, p. 54], se torna indiferença pela forma concreta em que este dispêndio é feito. 
Moishe Postone resume esta questão com grande clareza destacando, além disso, um outro aspecto deste processo: o trabalho se torna uma forma de mediação social.

Na sociedade determinada pela mercadoria, as objetivações do trabalho de alguém são um meio pelo qual bens produzidos por outros são adquiridos: alguém labora para adquirir outros produtos. (...) [O] trabalho, independentemente de seu conteúdo específico, serve ao produtor como um meio pelo qual os produtos de outros são adquiridos. O trabalho, em outras palavras, se torna um meio peculiar de adquirir bens na sociedade determinada pela mercadoria; a especificidade do trabalho dos produtores é abstraída dos produtos que adquirem com seu trabalho. Não há relação intrínseca entre a natureza específica do trabalho despendido e a natureza específica do produto adquirido por meio deste trabalho.

Isto é muito diferente de formações sociais nas quais a produção mercantil e as trocas não predominam, onde a distribuição social do trabalho e de seus produtos é efetuada por uma ampla variedade de costumes, laços tradicionais, relações abertas de poder, ou, concretamente, decisões conscientes. O trabalho é distribuído por relações sociais manifestas em sociedades não-capitalistas. Em uma sociedade caracterizada pela universalidade da formamercadoria, entretanto, um indivíduo não adquire bens produzidos por meio de relações sociais abertas. Ao contrário, o próprio trabalho - seja diretamente, seja representado em seus produtos - substitui estas relações servindo como um meio "objetivo" pelo qual os produtos de outros são adquiridos. O trabalho mesmo constitui uma mediação social, no lugar de relações sociais abertas. Isto é, uma nova forma de interdependência começa a existir: Ninguém consome o que produz, mas o próprio trabalho ou os próprios produtos, entretanto, funcionam como um meio para obter os produtos de outros [Postone 1993, pp. 149-50].

A indiferença com relação ao conteúdo do trabalho está então ligada à sua função de mediação social. Como o trabalho de cada indivíduo se destina a adquirir produtos feitos pelo trabalho de outros, a única coisa que interessa do caráter concreto do trabalho é que respeite o nível médio de produtividade, intensidade e de habilidade vigentes (ou vá além) e, portanto, o tempo de trabalho possa ser contado como "socialmente necessário" (ou mais do que isto). A permutabilidade geral dos produtos do trabalho, e a conseqüente indiferença com relação a seu conteúdo, significam que a igualdade fisiológica é posta 
socialmente como igualdade social, como homogeneidade, como base para a troca ${ }^{23}$. Torna-se um caráter social específico do trabalho ${ }^{24}$. Além disso, a indiferença com relação ao conteúdo do trabalho torna natural que o tempo de trabalho seja sua única medida.

Os desenvolvimentos que dão ao trabalho um caráter abstrato só se completam, como vimos no Capítulo 2, subseção 2.2.2, no capitalismo. O trabalho só adquire a impessoalidade necessária para a sua plena "permutabilidade", para a plena indiferença com relação a seu conteúdo, enquanto trabalho assalariado; só então a mediação pelo trabalho substitui as relações econômicas abertas dos indivíduos.

É possível dizer que esta indiferença é reforçada pelo desenvolvimento das técnicas de produção no capitalismo, que simplificam as tarefas do trabalhador e as tornam mais "abstratas", já que a divisão do trabalho faz que não haja mais propriamente um produto próprio do trabalhador. Pode-se falar, mesmo, numa "abstração fisiológica do trabalho", como faz David Gleicher [Gleicher 1983], referindo-se ao trabalho na era da maquinaria e da grande indústria; mas enquanto trabalho fisiológico, o trabalho jamais poderá ser considerado abstrato; permanecerá sempre concreto e heterogêneo, embora contenha aspectos fisiologicamente iguais ${ }^{25}$.

Por outro lado, Simon Mohun, que critica corretamente a posição de Gleicher, se equivoca quando contrapõe, como duas explicações excludentes, as transformações no processo de trabalho na era da maquinaria e da grande indústria e o desenvolvimento de relações sociais de troca como base para a abstração do trabalho [Mohun 1994, p. 218]. $\mathrm{Na}$ verdade, o desenvolvimento da forma social age sobre as características físicas, moldaas: este processo começa já com o desenvolvimento da produção de mercadorias (o produtor de mercadorias começa a ser obrigado a comparar o seu dispêndio de trabalho com o dos outros produtores), e é reforçado com a subsunção real do processo de trabalho ao capital (todos os elementos do processo de trabalho são comparados com os de outros, e é

\footnotetext{
${ }^{23}$ A questão da posição da igualdade social foi enfatizada por Ruy Fausto, e é um dos aspectos centrais abordados na subseção 3.3.7, como veremos.

${ }^{24}$ Como vimos na subseção 1.2.3 do Capítulo 1.

${ }^{25}$ Gleicher tende a apresentar o trabalho abstrato como uma evolução do próprio trabalho concreto, o que não se sustenta. O máximo que se pode dizer é que o desenvolvimento da produção de mercadorias reforça a base fisiológica necessária à constituição do trabalho abstrato.
} 
desenvolvido um esforço sistemático para reduzir seu tempo de duração, bem como para simplificá-los, etc.). No lugar de contrapor as duas explicações, seria mais correto apontar o caráter dominante do desenvolvimento das relações sociais mercantil-capitalistas no processo de constituição da dimensão abstrata do trabalho; as mudanças no trabalho concreto são subordinadas.

Ora, quando entendemos desta maneira o trabalho abstrato, sua realidade se torna clara. Marx já havia tocado neste ponto em Para a Crítica da Economia Política:

Essa redução [dos diversos trabalhos a trabalho sem diferenças, uniforme, simples] aparece como uma abstração, mas é uma abstração que é praticada diariamente no processo social de produção. (...) O trabalho que é medido desta maneira, isto é, pelo tempo de trabalho, aparece não como o trabalho de diferentes sujeitos, mas, ao contrário, os indivíduos diversos que trabalham aparecem como meros órgãos do trabalho. Ou seja, o trabalho, tal como se apresenta em valores de troca, poderia expressar-se como trabalho humano geral. Essa abstração do trabalho humano geral existe no trabalho médio, que qualquer indivíduo médio de uma sociedade dada pode executar; um gasto produtivo determinado de músculos, nervos, cérebro, etc. É trabalho simples, ao qual qualquer indivíduo médio pode ser adestrado, e que deve executar de uma ou outra forma. (...) Se $A$ produz ferro em seis horas e tecido em outras seis horas, e $B$ da mesma maneira produz ferro durante seis horas e durante outras seis horas produz tecido; ou se $A$ durante doze horas produz ferro e $B$ durante doze horas produz tecido, isso aparece obviamente como mera diferença no emprego do mesmo tempo de trabalho [Para a Crítica da Economia Politica, p. 33].

No interior do processo de produção em uma economia que troca os produtos de modo geral, um tempo de trabalho concreto qualquer pode adquirir qualquer valor de uso, torna-se representante do trabalho humano geral, e por isto seus aspectos particulares são abstraídos e ele se torna trabalho abstrato. O trabalho abstrato é pois uma abstração, mas "abstração que é praticada diariamente no processo social de produção".

É importante esclarecer um ponto que já havia sido tocado na subseção anterior (e no Capítulo 1), o papel do dinheiro na constituição do trabalho abstrato. No processo de generalização das trocas, o desenvolvimento do dinheiro é fundamental, como vimos no Capítulo 1, subseção 1.2.4. Mas não é o dinheiro que cria a comensurabilidade dos produtos do trabalho, e menos ainda a determinação quantitativa do valor: ele apenas permite que elas se desenvolvam. O ponto de partida da determinação do valor é o dispêndio de trabalho, são comparações de quantidades de trabalho. Estas se tornam possíveis pela exis- 
tência do dinheiro - mas dizer que o dinheiro é indispensável para tornar as quantidades de trabalho comparáveis é distinto de dizer que ele as cria.

Desta forma, se o trabalho abstrato depende do dinheiro para a sua formação, isto não significa que ele seja real apenas no dinheiro. Nem isto seria possível: o dinheiro é forma equivalente, e esta forma só existe numa relação com a forma relativa, como vimos no Capítulo 1, subseções 1.2 .2 e $1.2 .4^{26}$.

\subsection{3 - A quantificação do trabalho abstrato}

Isaak Rubin esclarece o significado do trabalho abstrato [Rubin 1980, Capítulo 14, e Rubin 1994] através de uma gradação de três variantes do conceito de trabalho igual ou homogêneo: trabalho fisiologicamente igual, trabalho socialmente igualado (como ele poderia ser considerado em uma economia socialista), e trabalho abstrato. A igualdade fisiológica é um dado da natureza (que pode ser reforçado por uma evolução histórica): todo trabalho é em última análise dispêndio de cérebro, músculos, nervos, mãos humanos. A igualdade social é resultado de um processo social. O trabalho abstrato é trabalho socialmente igualado, mas na forma específica da economia mercantil. Este último conceito inclui, portanto, os anteriores; é mais determinado, mais específico. Estas considerações são resumidas na seguinte definição:

Trabalho abstrato é a designação da parte do trabalho social que é igualada no processo de divisão social do trabalho através da igualação dos produtos do trabalho no mercado [Rubin 1994, p. 48].

Esta definição, no entanto, encerra um problema sério: pode ser interpretada no sentido de que "o trabalho abstrato só se origina no ato de troca, do que se segue que o valor também se origina apenas na troca" ${ }^{, 27}$ [Rubin 1980: 163; 1974: 201 e 1994: 52], mas esta conclusão é inaceitável para a teoria do valor de Marx: “(...) do ponto de vista de

\footnotetext{
${ }^{26}$ Forma equivalente geral e forma relativa geral do valor são dois pólos da mesma relação, e o dinheiro é equivalente geral. Ele só pode assumir esta forma enquanto expressão da dimensão de valor (um quantum de trabalho abstrato) das demais mercadorias que se encontram na forma relativa; não é concebível que o dinheiro seja real expressando um quantum de trabalho abstrato sem realidade.

${ }^{27}$ Posição que, como foi comentado na subseção 3.3.1, é defendida por vários autores que se inspiram no próprio Rubin.
} 
Marx, o valor, e dessa maneira também o trabalho abstrato, deve existir já no processo de produção" [Idem, idem].

Rubin se propõe a resolver este problema ${ }^{28}$, e constrói sua solução a partir da distinção entre dois sentidos de troca: forma social do processo de produção, e fase particular deste processo, que se alterna com a fase de produção. O trabalho abstrato se origina da troca como forma social particular do processo social de produção [Rubin 1980, p. 165; 1974, p. 203; e 1994, pp. 53-4]; é o que vimos na subseção anterior.

Isto tem uma conseqüência importante, pois, a partir do momento em que a troca é "realmente a forma dominante do processo de produção, ela deixa sua marca no processo de produção direta" [Rubin 1980, p. 165; 1974, p. 203; 1994, p. 54] [grifo JM]. Rubin prossegue esclarecendo:

Em outras palavras, desde que uma pessoa produza após ter deixado o ato de troca, e antes de adentrar no próximo ato de troca, o processo de produção direta adquire determinadas propriedades que correspondem à organização da economia mercantil baseada na troca. Mesmo que o produtor mercantil permaneça em sua oficina e num dado momento não entre na troca com os demais membros da sociedade, ele já sente a pressão de todas aquelas pessoas que entram no mercado como seus compradores, concorrentes, compradores de seus concorrentes, etc., em última análise, a pressão de todos os membros da sociedade. Esta relação econômica e essas relações de produção, que se realizam diretamente na troca, estendem sua influência mesmo depois do ato concreto de troca ter-se encerrado. Esses atos deixam uma nítida marca social no indivíduo e no produto do seu trabalho. Já no próprio processo de produção direta o produtor aparece como produtor mercantil, seu trabalho possui o caráter de trabalho abstrato, e seu produto o caráter de valor [Rubin 1980: 165-6; 1974: 203-4; e 1994:54].

Há uma passagem de Marx, já citada no Capítulo 1, subseção 1.2.3, em que ele diz que "tão logo a troca tenha adquirido extensão e importância suficientes", "o caráter de valor das coisas já [é] considerado ao serem produzidas", que confirma claramente esta interpretação:

\footnotetext{
${ }^{28} \mathrm{O}$ conjunto da discussão nesta subseção mostra que atribuir a Rubin a posição de que o trabalho abstrato e o valor são definidos no momento da troca, ou a posição de que a única medida do trabalho abstrato é o dinheiro, como fazem alguns dos autores que se inspiram no seu trabalho, e diversos críticos (como Gleicher [1983]), é incorreto.
} 
(...) [A] cisão do produto de trabalho em coisa útil e coisa de valor realiza-se apenas na prática, tão logo a troca tenha adquirido extensão e importância suficientes para que se produzam coisas úteis para serem trocadas, de modo que o caráter de valor das coisas já seja considerado ao serem produzidas [grifo JM]. A partir deste momento, os trabalhos privados dos produtores adquirem realmente duplo caráter social [O Capital I-I: 71; $\mathrm{El} \mathrm{Ca-}$ pital I-I, pp. 89-90].

Ruy Fausto argumenta na mesma direção, distinguindo cada troca da troca como processo social, embora esteja tratando uma questão um pouco diferente ${ }^{29}$ :

Marx escreve que, no início mesmo da troca — digamos, por ocasião da primeira troca os produtos (trata-se ainda de produtos, não de mercadorias) não se trocam por mercadorias (isto é, não adquirem a determinação formal do valor de troca) senão a partir do momento em que se opera a troca. (...) Os produtos somente são mercadorias antes da troca quando a produção já se faz tendo em vista a troca ... [Fausto 1983c, pp. 94-5]

Quando portanto a produção para a troca já é a forma dominante do processo de produção, e o caráter de valor das coisas já é considerado ao serem produzidas, a quantificação do trabalho abstrato, isto é, a determinação do valor, já é feita no momento da produção. Examinemos com um pouco mais de detalhe como isto acontece.

No momento em que é realizado, o trabalho abstrato já tem uma magnitude determinada:

É óbvio que, do ponto de vista da teoria de Marx, o trabalho abstrato tem uma magnitude determinada, e exatamente por causa disso o produto do trabalho não só adquire a forma social de valor como tem um valor de magnitude determinada [Rubin 1980: 168; 1974 : 206].

Para explicar como isto se dá, Rubin recorre à comparação do trabalho abstrato com o trabalho socialmente igualado em uma comunidade socialista. Através de diversos critérios, de redução do trabalho qualificado a trabalho simples, do trabalho do operário mais

\footnotetext{
${ }^{29}$ Fausto está respondendo a uma objeção de Castoriadis: "Marx diz, mais ou menos por toda parte, que as diferentes determinações do valor pressupõem a troca, mas ele diz também o contrário: 'O produto do trabatho adquire a forma mercadoria a partir do momento em que seu Valor adquire a forma do valor de troca, oposta à sua forma natural (...)" " [grifo de Castoriadis; trata-se de uma frase que Marx acrescentou à versão francesa de Roy; citado em Fausto 1983c, p. 94; cf. Castoriadis 1987, p. 280].
} 
experiente ao menos experiente, etc., que tornam o trabalho uma magnitude social, os órgãos da comunidade socialista medem quantas unidades de trabalho cada trabalhador realizou.

As unidades desse trabalho são unidades de uma massa homogênea de trabalho social, calculadas e igualadas por órgãos sociais. Simultaneamente, o trabalho social tem uma magnitude completamente determinada mas (e não se deve esquecer isto) uma magnitude de caráter puramente social. As 20 unidades de trabalho que constituem a quota de A não representam o número de horas trabalhadas, nem o montante de energia fisiológica realmente despendida, mas um número de unidades sociais de trabalho, isto é, uma magnitude social [Rubin 1980: 168; 1974: 207].

Acrescenta então que "[o] trabalho abstrato é precisamente uma magnitude social desse tipo". E esclarece: "[n]uma economia mercantil espontânea, ele desempenha o papel do trabalho socialmente igualado numa economia socialista organizada conscientemente" [Rubin 1980: 168]. Ao contrário da economia socialista, em que o trabalho dos diversos operários pode ser reduzido a unidades comuns a partir da aplicação consciente de determinados critérios, na economia mercantil é a troca que realiza esta redução, de forma espontânea.

Mas Rubin não estaria com isto caindo na conclusão que queria evitar, a de que o único critério de igualdade dos produtos do trabalho e do trabalho que os produz é o da sua aceitação no mercado, e portanto que a determinação quantitativa do trabalho abstrato e do valor seria realizada exclusivamente no momento da troca? Ele próprio repõe o problema:

A partir desse ponto de vista [o que aceita como único critério de igualdade do trabalho a igualação de seus produtos no ato da troca], não podemos falar de igualdade ou desigualdade de dois dispêndios de trabalho antes do momento de sua igualação social através do processo de troca. Por outro lado, se no processo de troca esses dois dispêndios de trabalho são igualados socialmente, devemos considerá-los iguais, ainda que não o sejam (...) no processo de produção direta. (...) Teríamos de admitir que a igualação social do trabalho no processo de troca é levada a cabo independentemente dos aspectos quantitativos que caracterizam o trabalho no processo de produção direta (por exemplo, a duração, a intensidade, a extensão do treinamento para um dado nível de qualificação, e assim por diante) e, desta maneira, faltaria à igualação social qualquer regularidade, posto que estaria determinada exclusivamente pela espontaneidade do mercado [Rubin 1980: 170-1; 1974: 208-9]. 
Para responder a esta questão, Rubin recorre novamente à comparação com a comunidade socialista, em que a igualação social dos trabalhos partiria justamente das suas características efetivas no processo técnico-material de produção; numa economia mercantil a igualdade social de dois gastos de trabalho se estabelece a partir dos mesmos critérios no processo social de troca (mas não apenas de cada troca particular). O mercado deve tomar como base

(...) uma série de propriedades quantitativas que distinguem o trabalho em termos de seus aspectos técnico-material e fisiológico, e que influenciam causalmente a determinação quantitativa do trabalho abstrato antes do ato de troca e independentemente dele ${ }^{30}$ Rubin 1980: 172; 1974: 210].

Essas propriedades quantitativas são: 1) a extensão do gasto de trabalho (esta é a propriedade básica, já que a medida do dispêndio de trabalho é em primeiro lugar seu tempo de duração; 2) a intensidade do trabalho; 3) a qualificação do trabalho; 4) a produtividade do trabalho ${ }^{31}$ [Rubin 1980: 172].

Voltando à comparação com o trabalho socialmente igualado numa comunidade socialista: neste caso, a autoridade planejadora define critérios para contar socialmente o tempo de trabalho, tomando como referência as propriedades quantitativas do trabalho concreto mencionadas; no caso da economia mercantil, o mercado (enquanto forma social, como processo de repetição) faz a mesma coisa.

Assim, o tempo de trabalho concreto é o ponto de partida para a medida do valor; mas deve ser reduzido a tempo de trabalho abstrato. O mercado, a partir da generalização da produção para a venda, deve levar em conta as características distintas do trabalho realizado, o que significa estabelecer "taxas de conversão" dos diversos dispêndios de trabalho para o trabalho simples e socialmente necessário ${ }^{32}$. O trabalho qualificado (complexo) deve

\footnotetext{
30 "Independentemente dele" (Rubin 1980: 172; 1974: 210): o sentido é claramente "independentemente de cada ato de troca", embora haja certamente dependência da regularidade das trocas.

${ }^{31}$ Rubin diz aqui "quantidade de produtos produzidos numa unidade de tempo" [Rubin 1980, p. 172]. Creio, contudo, que é preferível dizer "produtividade do trabalho", inclusive porque a quantidade de produtos produzidos numa unidade de tempo depende também da intensidade do trabalho, que foi mencionada antes.

${ }^{32}$ Estas “taxas de conversão", naturalmente, só são estabelecidas de forma prática e implícita, através do valor atribuído aos produtos do trabalho.
} 
ser reduzido a trabalho simples (não qualificado) e o trabalho individual a socialmente necessário (trabalho de intensidade, habilidade e produtividade vigentes). Não há maiores problemas para que o mercado leve em conta desigualdades na intensidade e na produtividade do trabalho individual (bem como diferenças naturais de habilidade) e reduza o tempo individual de trabalho a tempo socialmente necessário; simplesmente, trabalho que produz no mesmo intervalo de tempo mais produtos conta como trabalho de maior duração ${ }^{33}$. Alfredo Saad-Filho dá o nome de normalização a este processo de redução [Saad-Filho 1997, pp. 469-470] $]^{34}$. A redução do trabalho qualificado a trabalho simples é um tanto mais complicada, e trataremos dela na próxima subseção.

Este raciocínio deixa claro que o trabalho abstrato, se não é apenas trabalho fisiologicamente igual ou socialmente igualado, inclui estas determinações: é trabalho normalizado, socialmente igualado pelo mercado, a partir das suas características fisiológicas. Logo, o trabalho abstrato não faz um corte com o fisiológico, e menos ainda, obviamente, com o social; é gasto de trabalho fisiológico homogeneizado socialmente de uma maneira específica. Seu ponto de partida é o trabalho concreto, que é o modo como todo trabalho, seja determinado socialmente ou não, tem de existir.

Marco Lippi faz uma observação semelhante, comentando um parágrafo de Marx na discussão sobre o fetichismo da mercadoria. Destaca a sólida base natural ${ }^{35}$ em que se apóia a redução do trabalho concreto a trabalho homogêneo, isto é, abstrato:

${ }^{33}$ A determinação do tempo de trabalho socialmente necessário será discutida mais amplamente no Capítulo 5 .

${ }^{34}$ Naturalmente, não há normalização apenas do dispêndio de tempo de trabalho vivo, mas também do gasto de meios de produção (de trabalho morto). Aliás, John Weeks usa o mesmo termo, com o mesmo sentido, referindo-se explicitamente ao trabalho vivo e ao trabalho morto [Weeks 1981, p. 48; citaremos esta passagem na subseção 5.4.4 do Capítulo 5].

${ }^{35}$ Que a redução do trabalho concreto a abstrato tenha uma sólida base natural, porém, não lhe retira o caráter social, conforme fica claro na discussão na subseção 3.3.7. Falar de uma base natural é falar apenas de um ponto de partida, não elimina a necessidade de uma quantificação social, que é própria ao modo capitalista de produção (até porque é só neste modo de produção que o trabalho é quantificado enquanto abstrato). Não é possível atribuir à lei do valor o caráter de forma de uma lei natural, de uma lei da produção em geral. Lippi faz incorretamente esta caracterização, e a partir daí atribui a Marx um conceito naturalista do valor; incorre num erro simétrico ao da "escola de Rubin". Aproveitemos para destacar que no parágrafo citado, no 
(...) [A]pesar de não ser um traço comum a todos os modos de produção, a redução a trabalho homogêneo se apóia sobre uma sólida base natural: "O caráter místico da mercadoria não provém (...) de seu valor de uso. Ele não provém, tampouco, do conteúdo das determinações do valor. Pois, primeiro, por mais que se diferenciem os trabalhos úteis ou atividades produtivas, é uma verdade fisiológica que eles são funções do organismo humano e que cada uma dessas funções, qualquer que seja seu conteúdo ou forma, é essencialmente dispêndio de cérebro, nervos, músculos, sentidos etc. humanos. Segundo, quanto ao que serve de base à determinação da grandeza do valor, a duração daquele dispêndio ou a quantidade de trabalho, a quantidade é distinguível até pelos sentidos da qualidade do trabalho. Sob todas as condições, o tempo de trabalho, que custa a produção dos meios de subsistência, havia de interessar ao homem, embora não igualmente nos diferentes estágios de desenvolvimento" [Lippi 1979a, pp. 158-9; a citação de Marx é de O Capital I-I, p. 70; El Capital II, pp. 87-8].

Com o conceito de trabalho abstrato, não se trata de inventar um "trabalho" distinto do efetivamente realizado, que seria medido de um modo completamente diferente, mas sim de igualar socialmente o trabalho - o único trabalho existente. O trabalho abstrato nega o concreto, mas mantém um vínculo com ele ${ }^{36}$. Assim, fica claro que a magnitude do trabalho abstrato é definida na produção.

O mercado não pode definir a magnitude do trabalho abstrato, do valor, sem levar em conta a duração, a intensidade, a qualificação e a produtividade do trabalho que produz as mercadorias. Quando o mercado superavalia determinada quantidade de trabalho (isto é, atribui a ela um valor superior ao que lhe corresponderia), os capitalistas cujas mercadorias são beneficiadas com isto saem ganhando, elevam sua taxa de lucro, e há migração de capital e trabalho nesta direção; o contrário ocorre quando o mercado sub-avalia determinada quantidade de trabalho. A constante mobilidade do capital e do trabalho, portanto, leva ao ajuste das avaliações do quantum de trabalho abstrato feitas pelo mercado.

interior da própria discussão do fetichismo da mercadoria, Marx fala do trabalho abstrato como "dispêndio de cérebro etc.”, o que vai contra a interpretação desta questão por Rubin, criticada na mesma subseção 3.3.7.

${ }^{36}$ Por isto Weeks não tem razão na afirmação citada na subseção 3.3.1; o trabalho abstrato relaciona-se com o concreto, parte do fisiologicamente igual. Aliás, como fica claro quando diz que o trabalho abstrato é determinado a partir da normalização do trabalho concreto [Weeks 1981, p. 48], ele reconhece este vínculo. É difícil entender como, tendo esta compreensão, pôde fazer a afirmação citada na subseção 3.3.1. 
Podemos desenvolver a argumentação de Rubin observando que falar da troca como forma social particular do processo social de produção implica falar da concorrência, e portanto da pressão que ela faz para a homogeneização do trabalho (de sua intensidade, de sua produtividade) no próprio processo de produção. Os trabalhadores, defendendo suas condições de vida, tendem a homogeneizar seus gastos de trabalho, isto é, sua intensidade e sua duração. Ou seja: procuram recusar empregos em que tenham de trabalhar com intensidade e duração maiores do que a média social vigente, além de lutarem para reduzi-las. Os capitalistas, defendendo suas taxas de lucro, tendem também a forçar a homogeneização da intensidade do trabalho, e a homogeneizar a habilidade média (conseguindo que o trabalho realizado seja socialmente necessário) e sua produtividade ${ }^{37}$, além de homogeneizar também o dispêndio de meios de produção. Já abordamos esta questão, tratada por Marx no Capítulo V do Livro I de O Capital, na subseção 1.4.3.

Como vimos na subseção 2.2.2, o grau de monetização da economia é fundamental para impulsionar este processo de homogeneização. Por um lado, torna possível a comparação de diferentes gastos de trabalho e de meios de produção; por outro lado, obriga a evitar qualquer gasto além do socialmente necessário, estabelece uma tendência à generalização de um trabalho vivo de características médias e a gastos médios de trabalho morto (de meios de produção) ${ }^{38}$. O trabalho abstrato se efetiva apenas no capitalismo desenvolvido: não apenas pela generalização das trocas, mas também pela homogeneização (tendencial) das condições de produção, das condições de trabalho, que elas forçam.

Há uma última dificuldade que deve ser enfrentada nessa discussão do trabalho abstrato, quando examinamos esta questão em conexão com a teoria dos preços de produção, e não apenas em conexão com a teoria do valor em geral. Se a magnitude do trabalho abstrato é definida a partir do processo de produção, mas socialmente reconhecida apenas no momento da troca - é medida portanto pelo mercado - não se segue então que desaparece a possibilidade da distinção entre valor e preço de produção? Pois a magnitude que

\footnotetext{
${ }^{37}$ Naturalmente, a concorrência tem efeitos contraditórios, e esta tendência à homogeneização é sempre negada pelas tentativas de reduzir custos a partir da introdução de progresso técnico, do aumento da intensidade do trabalho, etc. Voltaremos a esta questão no Capítulo 5.

${ }^{38}$ É curioso que um autor que destaca corretamente esta questão (John Weeks) chegue à conclusão bastante incoerente de que o trabalho abstrato não tem nenhuma relação com o tempo de trabalho concreto.
} 
o mercado reconhece na média deveria ser o valor, e isto explicaria a diferença entre valor e preço de mercado: este seria o que o mercado estabelece de cada vez, aquele seria a média desse movimento. Mas, se consideramos a tendência à igualação das taxas de lucro, esta média é o preço de produção, não o valor. Desta maneira, estes dois conceitos são superpostos, confundidos. Ou no máximo a distinção entre eles se tornaria puramente analítica, lógica, não corresponderia a uma distinção real.

É possível dizer que este argumento confunde duas coisas: existência real e aparência. A distinção entre valor e preço de produção não aparece para cada mercadoria individual; de fato, o mercado só permite identificar (tanto estatisticamente como na prática social) uma média, que é o preço de produção. Ou seja, através de uma pesquisa empíricoestatística, não chegaremos ao valor como conceito distinto do preço de produção. Mas isto não significa que esta distinção não exista.

$\mathrm{Na}$ verdade, a operação de reconhecimento social de uma dada magnitude de valor realizada pelo mercado é muito complexa: a repetição e o estabelecimento de uma norma social permitem tanto a passagem do trabalho concreto ao abstrato, como do trabalho de intensidade distinta da média ao de intensidade média, do complexo ao simples, do individual ao socialmente necessário. E, além disso, tendo em vista a diversidade dos capitais, e a tendência à igualação das taxas de lucro, o mercado efetua também redistribuições de valores entre os vários setores. Se, por um lado, a distinção entre valor e preço de produção de uma mercadoria não aparece em cada caso, por outro lado a realidade do valor como realidade distinta do preço de produção e logicamente anterior a ele se verifica em que é a soma de trabalho abstrato objetivado que define a soma dos preços de produção ${ }^{39}$. Com base nisto, Guglielmo Carchedi e Werner de Haan [1996] propõem um método para calcular os valores a partir dos preços de mercado.

\subsection{4 - Trabalho complexo / trabalho simples}

A questão da redução do trabalho complexo (qualificado) a trabalho simples tem sido objeto de debate; é considerada por alguns autores um problema de solução difícil, senão impossível, para a economia marxista.

\footnotetext{
${ }^{39}$ Este tema será abordado no Capítulo 4.
} 
Como exemplo, Philip Harvey [Harvey 1985] argumenta que

(...) [A] natureza da relação entre a teoria do valor da força de trabalho de Marx e sua teoria geral do valor torna improvável que qualquer solução satisfatória para o problema da redução [do trabalho complexo a trabalho simples] exista [Harvey 1985, p. 84].

Harvey desenvolve seu argumento por meio de uma avaliação crítica de duas soluções propostas para este problema.

Marx, no Capítulo 1, disse que o trabalho complexo vale "como trabalho simples potenciado ou, antes, multiplicado”, sem explicar esta multiplicação. No Capítulo V do Livro I, acrescentou o seguinte:

(...) [P]ara o processo de produção, é totalmente indiferente se o trabalho apropriado pelo capitalista é trabalho simples, trabalho social médio ou trabalho mais complexo, trabalho de peso especifico superior. O trabalho que vale como trabalho superior, mais complexo em face do trabalho social médio, é a exteriorização de uma força de trabalho na qual entram custos mais altos de formação, cuja produção custa mais tempo de trabalho e que, por isso, tem valor mais elevado que a força de trabalho simples. Se o valor desta força é superior, ela se exterioriza, por conseguinte, em trabalho superior e se objetiva nos mesmos periodos de tempo, em valores proporcionalmente mais altos [O Capital I-I, p. 155; El Capital I-I, p. 239].

Podemos dividir o argumento de Marx neste parágrafo em duas partes:

1. O trabalho complexo vale como trabalho superior ao simples porque é a exteriorização de uma força de trabalho na qual entram custos mais altos de formação, cuja produção custa mais tempo de trabalho, e por isto tem valor mais elevado do que a força de trabalho simples.

2. Se o valor desta força de trabalho é superior, ela se objetiva, nos mesmos períodos de tempo, em valores proporcionalmente mais altos.

Marx parece estar atribuindo a capacidade do trabalho complexo de criar mais valor em um mesmo período ao maior valor da força de trabalho qualificada; a razão dos valores das forças de trabalho estabeleceria uma "taxa de conversão" do valor criado pelo trabalho complexo em trabalho simples. Harvey (e numerosos outros autores) criticam esta posição por julgarem-na inconsistente com a base fundamental da explicação para existência da mais-valia, que é justamente a separação entre a criação de valor e o valor da força de trabalho [Harvey 1985, p. 84]. 
Rudolf Hilferding [1974 — publicado inicialmente em 1904] propôs uma interpretação da posição de Marx que não estaria sujeita a esta crítica: o dispêndio de trabalho qualificado contaria simultaneamente como dispêndio do trabalho necessário para a qualificação. A maior capacidade de produzir valor seria assim o resultado da condensação do dispêndio atual e pretérito de tempo de trabalho. Mais recentemente, Bob Rowthorn [1982, Capítulo 8] retomou e desenvolveu a abordagem de Hilferding.

Harvey aponta que esta concepção, de fato, não trata a força de trabalho qualificada como tendo uma maior capacidade de criar valor, mas sim de preservar valor, de uma maneira análoga à do capital constante [Harvey 1985, p. 87]. O que há é uma transferência de valor, do passado para o presente. A partir daí, mostra que esta abordagem tem numerosas inconsistências, que podem ser relacionadas com o fato de que nela, no lugar de o trabalho qualificado criar mais valor como um múltiplo do trabalho simples (incorporando um fator multiplicativo, portanto), ele apenas adiciona um tempo de trabalho passado. Harvey não vê como sair dos dilemas das duas abordagens propostas.

Saad-Filho propõe uma maneira de definir um fator multiplicativo distinta do recurso à proporção dos valores das forças de trabalho: atribuir ao mercado, através da fixação do preço dos produtos, a definição da relação entre o tempo de trabalho qualificado e o tempo de trabalho simples [Saad-Filho 1997, p. 472]. Esta posição, contudo, implica um raciocínio circular, se pretendemos (como deve ser o caso) explicar a formação dos valores e (com base neles) dos preços, a partir do tempo de trabalho simples objetivado nas mercadorias. Além disto, levaria a que a determinação do quantum de trabalho abstrato e de valor se fizesse apenas no momento da venda.

Não haveria outra maneira de definir uma "taxa de conversão" multiplicativa do tempo de trabalho qualificado em trabalho simples?

Em primeiro lugar, não há razão para falar no preço dos produtos como critério; o recurso ao mercado não obriga a isto. É possível falar em valor, desde que pensemos num processo social repetido de vendas que estabelece uma regularidade, e não em vendas isoladas.

Mas o mercado estabelecerá valores dos produtos independentes do valor da força de trabalho? Não, como explica Rosdolsky.

(...) $[\mathrm{N}] \mathrm{o}$ processo social de equiparação de diversos trabalhos, o maior dispêndio de trabalho que a sociedade capitalista deve realizar para habilitar forças de trabalho qualificadas 
não pode expressar-se de outro modo que não seja o caminho da "avaliação" superior dos produtos elaborados por essas forças de trabalho. (Se não fosse assim, nenhum empresário se disporia a pagar, aos trabalhadores qualificados, salários mais altos. A conseqüência seria uma debandada dos trabalhadores dessas profissões, que duraria até que a demanda dos produtos em questão fizesse aumentar seus preços, forçando assim a formação de novos trabalhadores qualificados.) [Rosdolsky 2001, p. 432]

Voltamos, assim, à proposta de Marx, criticada por Harvey e outros como incoerente com a teoria da mais-valia.

Mas esta incoerência existe de fato? Rosdolsky afirma que não, embora não desenvolva o argumento ${ }^{40}$.

Na verdade, a questão é menos complicada do que parece. A teoria da mais-valia se baseia em que o valor criado pelo trabalho é diferente do valor da força de trabalho; mas não impede que quantidades de valor criadas em determinado intervalo de tempo por trabalhadores diferentes sejam proporcionais ao valor das respectivas forças de trabalho. Valores dos produtos e valores de forças de trabalho são determinados socialmente; resultam de um processo de avaliação social feito com base no mercado. A própria coerência destas avaliações sociais leva a que as proporções de uns e outros sejam as mesmas, como fica claro com o argumento de Rosdolsky.

\subsection{5 - A sincronização dos trabalhos}

Há um aspecto adicional na determinação do tempo de trabalho socialmente necessário, que é chamado por Saad-Filho de sincronização. Como ele explica:

A venda simultânea, pelo mesmo preço, de mercadorias produzidas em diferentes momentos, mostra que os trabalhos concretos individuais são sincronizados entre os que produziram o mesmo tipo de mercadoria em um outro ponto do tempo, e com tecnologias possivelmente diferentes. Porque os trabalhos são normalizados ${ }^{41}$ e sincronizados, todas as mercadorias do mesmo tipo têm o mesmo valor, independentemente de como, quando e por quem foram produzidas. A normalização explica por que o tempo de trabalho necessário à

\footnotetext{
${ }^{40}$ Há outros autores que também adotam este ponto de vista, sem se preocuparem com a crítica: Isaac Rubin [1980, Capítulo 15] e Guglielmo Carchedi [1991, p. 13].

${ }^{41}$ Transformados em trabalho socialmente necessário. Ver subseção 3.3.3.
} 
produção de um tipo de mercadoria é determinado socialmente, e compreende o necessário para produzir os insumos. A sincronização implica que este tempo de trabalho é equivalente ao trabalho vivo, e é determinado pelo tempo de trabalho necessário no presente para a produção (e não pelo tempo de trabalho necessário quando a produção pode ter ocorrido).

Esta colocação de Saad-Filho é correta, e pode ser demonstrado que corresponde à posição do próprio Marx (como Saad-Filho faz); mas exige uma qualificação importante ${ }^{42}$ (desconsiderada por Saad-Filho), a não ser que fiquemos num nível de abstração demasiado alto.

Quando levamos em conta que a produção de cada tipo de mercadoria não é feita por capitais que têm condições de produção tecnicamente homogêneas, mas sim por capitais com distintos níveis tecnológicos, torna-se necessário introduzir a distinção entre valores individuais e valores sociais (ou de mercado), e tratar a determinação do tempo de trabalho socialmente necessário como um processo complexo e dependente das condições da produção e da demanda social ${ }^{43}$. O "tempo de trabalho necessário no presente para a produção" não é determinado a partir da melhor tecnologia disponível, nem apenas por condições técnicas; depende das condições concretas do mercado do produto em questão.

Quando uma nova tecnologia começa a ser utilizada economicamente, dá início a um processo de reavaliação do tempo de trabalho socialmente necessário, que vai depender do número de empresas que a utilizam e de seu peso no setor, etc.; quanto maior o peso das empresas que utilizarem a tecnologia de ponta, mais próximo o tempo de trabalho socialmente necessário ficará daquele que lhe corresponde, como veremos no capítulo 5. Em cada momento haverá um único valor social, e portanto uma normalização dos tempos de trabalho necessários para as diversas condições de produção. Um processo semelhante de reavaliação — de sincronização — se desenvolverá com relação ao valor das mercadorias já existentes, incluindo os meios de produção, afetando portanto o valor transferido por eles às novas mercadorias. Se novas máquinas começam a ser produzidas com melhor tecnologia, as antigas começarão a perder valor, mas seu novo valor não dependerá apenas da nova tecnologia, mas também das condições concretas do setor que as produz.

\footnotetext{
${ }^{42}$ Que também corresponde à posição de Marx, como veremos no Capítulo 5.

${ }^{43}$ A questão da determinação dos valores sociais a partir dos valores individuais será analisada no Capítulo 5.
} 
Isto tem uma conseqüência de grande importância: enquanto as novas tecnologias não se generalizarem, isto é, enquanto não se tornarem a referência para a fixação do tempo de trabalho socialmente necessário, o trabalho que as utiliza contará como trabalho de duração maior do que seu tempo concreto de duração. Por outro lado, o trabalho realizado com tecnologias obsoletas contará como trabalho de menor duração.

\subsection{6 - O reconhecimento social do trabalho}

Vimos, na subseção 1.3.1 do Capítulo 1, que, embora os preços sejam expressão do valor - e portanto de quantidades de trabalho abstrato - em dinheiro, faz parte da sua lógica poder expressar o valor com um desvio; esta é, mesmo, uma das razões que tornam impossível, numa economia mercantil, substituir o dinheiro por "recibos de tempo de trabalho" 44 .

A explicação disto é que o trabalho concreto efetivado na produção é trabalho privado, e apenas indiretamente social; adquire um caráter social abstrato enquanto trabalho para a venda, trabalho geral, permutável ${ }^{45}$. A determinação do valor de uma mercadoria, realizada no processo de produção, já é uma determinação social. Mas esta primeira determinação social não lhe basta; necessita de uma confirmação, de um reconhecimento social.

Este reconhecimento é realizado no momento da venda; até então todas as possibilidades ficam abertas diante da mercadoria produzida. Em condições de equilíbrio entre oferta e demanda, ela pode obter um preço correspondente a seu valor (ou, para dizer de modo mais rigoroso, a seu preço de produção); isto significa um reconhecimento social integral do trabalho que a produziu. Se no entanto a produção foi excessiva, ela pode obter apenas um preço inferior, ou não obter preço algum; haverá então um não reconhecimento parcial ou total do trabalho que a produziu. É possível ainda que a demanda social lhe seja favorável, e que ela obtenha um preço superior a seu valor (a seu preço de produção), o que equivale a um "sobre-reconhecimento" do trabalho que a produziu.

\footnotetext{
${ }^{44}$ Como vimos na subseção citada, há outra razão para isto, que é a necessidade de o tempo de trabalho concreto ser socialmente transformado em tempo de trabalho abstrato, socialmente necessário.

${ }^{45}$ Como vimos na subseção 1.2 .3 do Capítulo 1.
} 
O que é importante, para manter a coerência da distinção entre preço e valor, é separar a determinação do valor no processo de produção (que já é resultado, como vimos, de um processo social) do seu reconhecimento no momento da venda. A mercadoria já tem, ao ser produzida, um caráter duplamente social: indiretamente social como valor de uso, e abstratamente social como valor ${ }^{46}$. Falta-lhe, contudo, até o momento da venda, um terceiro caráter social, o de socialmente reconhecida.

A confusão do caráter social que a mercadoria já tem como valor no momento da produção, a partir do desenvolvimento do processo social das trocas, com o reconhecimento social que ela obtém apenas no momento da venda (no ato da sua troca individual), é uma das bases das interpretações que afirmam que o valor é determinado no momento da venda e que portanto identificam valor e preço.

\subsection{7 - O puro dispêndio produtivo de cérebro, músculos, nervos, mãos}

\section{humanos}

No Capítulo I do Livro I de O Capital, Marx introduz o conceito de trabalho humano abstrato. Em primeiro lugar, ele é apresentado como a negação das características concretas, úteis, do trabalho:

Ao desaparecer o caráter útil dos produtos do trabalho, desaparece o caráter útil dos trabalhos nele representados e desaparecem também, portanto, as diferentes formas concretas desses trabalhos, que deixam de diferenciar-se uns dos outros para reduzir-se em sua totalidade a igual trabalho humano, a trabalho humano abstrato [O Capital I-I, p. 47; El Capital, p. I-I, p. 47].

Mais adiante, no mesmo capítulo, Marx precisa um pouco mais este conceito:

(...) $[\mathrm{M}]$ as a alfaiataria e a tecelagem são trabalhos qualitativamente diferentes. Existem, entretanto, circunstâncias sociais em que a mesma pessoa, alternadamente, costura e tece. Esses dois modos diferentes de trabalho são, por isso, apenas modificações do trabalho do mesmo indivíduo; não chegaram a ser funções especiais, fixas, de indivíduos diferentes, do mesmo modo, exatamente, que o casaco feito, hoje, por nosso alfaiate, e as calças que ele faz amanhã somente pressupõem variações do mesmo trabalho individual. A evidência ensina ainda que em nossa sociedade capitalista, conforme a mutável orientação da procura

\footnotetext{
${ }^{46}$ Como vimos na subseção 1.2.3 do Capítulo 1.
} 
de trabalho, dada porção de trabalho humano deverá ser alternadamente oferecida ora sob a forma de alfaiataria, ora sob a forma de tecelagem. Essa variação da forma de trabalho pode não transcorrer sem atritos, mas ocorre necessariamente. Abstraindo-se da determinação da atividade produtiva e, portanto, do caráter útil do trabalho, resta apenas que ele é um dispêndio de força humana de trabalho. Alfaiataria e tecelagem, apesar de serem atividades produtivas qualitativamente diferentes, são ambas dispêndio produtivo de cérebro, músculos, nervos, mãos etc. humanos, e neste sentido são ambas trabalho humano. São apenas duas formas diferentes de despender força humana de trabalho [O Capital I-I, p. 51; El Capital, p. I-I, p. 54] $]^{47}$.

Vale a pena destacar, aqui, que os grifos são do próprio Marx, na primeira edição do Livro ${ }^{48}$; enfatizam o caráter genericamente humano do trabalho abstrato.

A conceituação do trabalho abstrato feita nestes parágrafos é avaliada criticamente por diversos autores da "escola do trabalho abstrato". Vêem aí o problema apontado por Ruy Fausto nas "leituras vulgares" do trabalho abstrato, que reproduzimos na subseção 3.3.1: Marx estaria expondo aí uma "concepção fisiológica" e trans-histórica do trabalho abstrato; isto seria incoerente com as diversas vezes em que se referiu ao trabalho abstrato como uma realidade social (e como uma abstração real), historicamente constituído pela generalização das trocas.

Desde Böhm-Bawerk no fim do século XIX, muitos afirmam a incoerência de Marx. Um autor, Gilbert Faccarello, chega a ver em $O$ Capital nada menos do que quatro conceitos contraditórios de trabalho abstrato, construídos a partir de três linhas divergentes de raciocínio: naturalística, sociológica (ou qualitativa), e dialética [Faccarello 1998].

Dois dos autores que julgam problemática a definição inicial do trabalho abstrato desenvolveram argumentos bastante sofisticados para justificar por que Marx a apresentou. Um deles é Isaac Rubin, para quem a aparente incoerência de Marx na sugestão de uma "concepção fisiológica" do trabalho abstrato se explicaria pelo método inicial usado para derivar este conceito - o método analítico. Com este método, quando partimos do valor, não seria possível chegar ao trabalho abstrato como "socialmente igualado na forma espe-

\footnotetext{
${ }^{47}$ Foram feitas pequenas adaptações na redação da tradução brasileira, com base na edição Siglo Veintiuno, em benefício da clareza.

${ }^{48}$ Conforme esclarecido na nota 8 do Capítulo 1.
} 
cífica da economia mercantil"; seria possível chegar ao conteúdo do trabalho abstrato, mas não à sua forma social. Apenas o procedimento inverso, genético, de partir do trabalho já como se apresenta na economia mercantil, adotado a partir da terceira parte do Capítulo I do Livro I, permitiria chegar ao valor e assim fundamentar o trabalho abstrato como um conceito socialmente determinado [Rubin 1980, Capítulo 12, especialmente pp. 132-3, e Capítulo 14].

Moishe Postone explica a apresentação do trabalho abstrato como trabalho fisiológico pelo caráter de "análise imanente" que sua exposição inicial de O Capital tem [Postone 1993, p. 166]. Este tipo de análise é necessário, pois a crítica de Marx do capitalismo é uma crítica de um objeto social historicamente específico feita do seu interior, e deve portanto ser uma crítica auto-reflexiva. Não é possível fazer a crítica do capitalismo de modo teoricamente rigoroso colocando-se fora dele, adotando um ponto de vista transhistórico ou transcendental [Postone 1993, p. 140]. Partindo desta compreensão,

(...) Marx sente-se então compelido a construir sua apresentação crítica da sociedade capitalista de uma maneira rigorosamente imanente, analisando esta sociedade nos seus próprios termos, por assim dizer. O ponto de vista da crítica é imanente a seu objeto social; funda-se no caráter contraditório da sociedade capitalista, que aponta para a possibilidade de sua própria negação [Postone 1993, p. 140].

Esta forma imanente da exposição pode facilmente ser interpretada incorretamente; pode-se acreditar que Marx diz justamente o que quer negar. Depois de explicar que "quando a análise parte de um exame das mercadorias para descobrir o que constitui seu valor, pode chegar até o valor - mas não à sua função mediadora" [Postone 1993, p. $168]^{49}$, isto é, não pode descobrir seu caráter social, Postone conclui que:

(...) [A] análise da categoria de trabalho abstrato é uma elaboração própria da natureza imanente da crítica de Marx. Sua definição fisiológica desta categoria é parte de uma análise do capitalismo nos seus próprios termos, isto é, como suas formas elas próprias se apresentam. A crítica não parte de uma posição fora do objeto, mas se apóia, ao contrário, no completo desdobramento das categorias e em suas contradições [Postone 1993, p. 170].

\footnotetext{
$49 \mathrm{Ou}$ seja, à sua forma social. Postone atribui a Marx a definição do trabalho abstrato como "a função do trabalho como atividade social mediadora" [Postone 1993, p. 150], já que é através da constituição do trabalho abstrato e de sua representação como valor das mercadorias que as trocas são viabilizadas — desta forma o trabalho humano cumpre um papel de mediação social.
} 
Na seqüência, Postone afirma que a argumentação de Marx no Capítulo I do Livro I adota uma "forma descontextualizada" historicamente; a "definição fisiológica" do trabalho abstrato seria uma das conseqüências desta descontextualização; esta se explicaria também pelo fato de Marx estar adotando um ponto de vista imanente, isto é, interno ao próprio capitalismo.

Roman Rosdolsky argumenta em sentido contrário: a definição aparentemente fisiológica do trabalho abstrato é apenas a primeira parte da solução do problema, e deve ser completada depois. Nem ela pretende dizer o contrário do que parece (como argumentam Rubin e Postone), nem é incorreta, mas apenas incompleta:

Marx perguntava: como podemos considerar que o trabalho é a substância do valor se, na realidade, cada trabalho concreto serve a uma finalidade distinta, sendo realizado por indivíduos com diferentes capacidades, habilidades, etc.? Como é possível reduzir a um denominador comum a infinita multiplicidade dos tipos de trabalho, diferentes individual e profissionalmente? Isso é possível, dizia Marx: "Em primeiro lugar, por mais diferentes que sejam os trabalhos úteis ou as atividades produtivas, é uma verdade, do ponto de vista $f i$ siológico, que se trata de funções do organismo humano; todas essas funções, sejam quais forem seu conteúdo e sua forma, são essencialmente gasto de cérebro, nervos, músculos, órgãos sensoriais etc, humanos" ${ }^{30}$.

A igualdade fisiológica dos trabalhos humanos é uma precondição necessária à relação de valor. Mas é apenas uma precondição! Pois seria errôneo localizar no conceito fisiológico de trabalho a essência da teoria marxiana do valor, como fazem muitos de seus críticos. (...) Na verdade, por enquanto conhecemos apenas a primeira parte da solução marxiana do problema. Pois, embora em qualquer sociedade seja possível reduzir fisiologicamente o trabalho a um gasto simples de força de trabalho, semelhante redução só é exigida, na prática, em determinada etapa do desenvolvimento histórico, e só nela, de fato, tem lugar. Isso ocorre exclusivamente em uma sociedade de proprietários de mercadorias. Nela, como a troca constitui o único vínculo econômico entre os indivíduos, as mercadorias devem ser consideradas como produtos do trabalho médio, indiferenciado, ou seja, 'gasto de força de trabalho humana sem consideração à forma como foi gasta'. [Rosdolsky 2001, pp. 446447].

\footnotetext{
${ }^{50}$ Rosdolsky cita aqui uma passagem do Capítulo I do Livro I: O Capital I-I, p. 70; El Capital I-I, p. 87. Acrescentamos os grifos feitos pelo próprio Marx, de acordo com a edição Siglo Veintiuno.
} 
Em resumo: em qualquer sociedade é possível reduzir o trabalho humano a um simples gasto de força de trabalho; mas isto só é necessário, e só se faz de fato, só é transformado no vínculo social entre os produtores, na economia mercantil ${ }^{51}$.

Ruy Fausto, por outro lado, apresenta um argumento semelhante ao de Rosdolsky destacando seus aspectos lógicos: a realidade social põe a "generalidade em sentido físiológico" como trabalho abstrato. Dizendo de outra maneira, a posição da generalidade fisiológica é social; é a partir desta posição que o "dispêndio produtivo de cérebro, músculos, nervos, mãos etc. humanos" é constituído como trabalho abstrato.

Dizer que a abstração do trabalho não se confunde com a simples generalidade 'trabalho' não quer dizer que a primeira exclua toda generalidade. Na realidade, as abstrações reais 'trabalho' e 'valor' põem a generalidade. Ou antes, elas põem a universalidade, mas esta universalidade é generalidade posta. O 'geral' se torna universalidade singular, universal concreto. (...)

Estamos pois diante de uma universalidade (Allgemeinheit) que é ao mesmo tempo singularidade. Mas qual é a relação existente entre uma universalidade como esta e a representação da realidade fisiológica da abstração do trabalho? Conservando o lado da 'universalidade' (e portanto em certo sentido a 'generalidade', mesmo se se trata da generalidade 'negada'), não seríamos reconduzidos de novo ao nível fisiológico? A resposta já está dada na noção de posição. Não é a realidade biológica da universalidade do trabalho que constitui o trabalho abstrato, mas a posição desta realidade, e a posição já não é mais biológica. A generalidade em sentido fisiológico (não mais do que a generalidade abstrata e subjetiva) retomamos o problema num nível mais elevado - não constitui o trabalho abstrato: ela é apenas a realidade natural pressuposta à (posição) deste. A realidade social faz com que valha o que era apenas realidade natural. [Fausto 1983c,p p. 91-92]

Este argumento de Ruy Fausto pode ser considerado uma maneira de dizer que a igualdade fisiológica dos trabalhos humanos é a base necessária para a constituição do trabalho abstrato, mas que esta só se efetiva enquanto tal socialmente, quando a generalização

\footnotetext{
51 Além disto: o tempo de trabalho interessa à humanidade em todos os modos de produção, mas só se transforma no vínculo social entre eles na economia mercantil. É por não apreciar de modo satisfatório este ponto que Lippi não percebe que a redução do trabalho concreto a abstrato, por mais que tenha base natural, é um processo social, e atribui a Marx um conceito naturalista de valor. Ver nota 33 na subseção 3.3.3.
} 
das trocas, da produção para a venda, torna indiferente o conteúdo concreto do trabalho (tal como foi exposto na subseção 3.3.2) ${ }^{52}$.

A argumentação de Roman Rosdolsky e Ruy Fausto é perfeitamente satisfatória, enquanto nem a argumentação de Rubin, nem a de Postone, são muito convincentes nesta questão. Explicações engenhosas para a aparente incoerência de Marx na conceituação do trabalho abstrato não são necessárias.

Ao contrário, é possível dizer que há alguma incoerência na crítica. Rubin, por exemplo, reconhece que o trabalho abstrato inclui a igualdade fisiológica, embora não se reduza a ela. Não tira corretamente, contudo, as conseqüências disto; quando põe a igualdade fisiológica como ponto de partida, está de fato dizendo que o trabalho abstrato é em primeiro lugar um "dispêndio de cérebro, músculos, nervos, mãos etc. humanos", embora não o reconheça. Assim, mais correto do que dizer que a análise inicial de Marx não permite chegar ao trabalho abstrato é apontar simplesmente que ela é insuficiente, e é completada a seguir. Como vemos pela citação da p. 51 de $O$ Capital I-I acima, que se refere à segunda parte do Capítulo I, Marx já aí deixa claro que o trabalho humano é considerado como puro "dispêndio de força humana de trabalho" "em nossa sociedade capitalista" [grifo JM], e explica por que! Apenas a primeira referência ao trabalho abstrato deixa de explicitar seu vínculo com a economia capitalista; mas ela aparece poucos parágrafos depois da frase inicial, que situa a análise da mercadoria "nas sociedades em que domina o modo de produção capitalista” [O Capital I-I, p. 45; El Capital I-I, p. 43].

O argumento de Postone não se mostra menos problemático, e pode ser considerado ainda mais difícil de entender dentro da sua posição de conjunto, já que este autor enfatiza de modo muito forte que o valor é uma categoria da produção. Postone dá uma contribuição importante para a compreensão de $O$ Capital quando chama a atenção para o caráter imanente da sua argumentação inicial; mas é impossível aceitar que ela seja "descontextualizada": já a primeira frase de $O$ Capital faz referência ao modo capitalista de produção, e depois o contexto sócio-histórico da análise fica cada vez mais claro, como vimos no Capítulo 1.

\footnotetext{
${ }^{52}$ Naturalmente, a argumentação de Ruy Fausto toca em outras questões; especialmente interessante é a afirmação de que a posição da generalidade a transforma em universalidade, uma universalidade que é também singular; o trabalho abstrato é pois um universal concreto.
} 
Podemos concluir pela aceitação da "definição fisiológica" do trabalho abstrato como ponto de partida da explicitação deste conceito, e chegar à seguinte formulação:

Trabalho abstrato é o trabalho reduzido a puro dispêndio produtivo de cérebro, músculos, nervos, mãos etc. humanos; esta redução torna-se um fato real quando o desenvolvimento da produção mercantil generalizada (a economia capitalista) permite que o produto de um trabalho possa ser sempre trocado por outro, e desta maneira promove nos trabalhadores (e nos capitalistas que os contratam) a indiferença com relação ao conteúdo concreto do trabalho ${ }^{53}$. A intercambiabilidade dos produtos dá ao trabalho um caráter social específico, uma função de mediação social. Em resumo: trabalho abstrato é o puro exercício da capacidade de produzir, independentemente do seu conteúdo concreto, que ganha existência real com a permutabilidade geral dos seus produtos.

\subsection{8 - Trabalho abstrato e valor: categorias da produção}

Esta definição é mais clara do que a proposta por Isaac Rubin, reproduzida na subseção 3.3.3; tem a grande vantagem de ancorar mais claramente o conceito de trabalho abstrato na produção, reconhecendo por outro lado que a abstração do trabalho é realizada pela generalização das trocas e, portanto, da produção mercantil.

O problema da definição de Rubin é o de centrar-se na igualação realizada pelo mercado; com isto, dá à produção um lugar secundário ${ }^{54}$, e abre o caminho para a interpretação de que a igualação em questão é feita em cada troca. Além disto, embora a crítica à "concepção fisiológica" de trabalho abstrato ${ }^{55}$ seja correta, a ênfase nesta crítica cria uma certa confusão, ao sugerir um corte entre o trabalho abstrato e o "dispêndio produtivo de força de trabalho" ${ }^{, 56}$. Quando é posto diante da possível conclusão de que o trabalho abstrato tem origem no ato da troca, no entanto, Rubin faz meia-volta e fundamenta de

\footnotetext{
${ }^{53}$ Como vimos na subseção 3.3.2, do caráter concreto do trabalho só interessa seu nível de produtividade, intensidade e habilidade - uma forma de interesse pelo trabalho concreto desligada do seu conteúdo propriamente dito.

${ }^{54} \mathrm{O}$ que é curioso, pois afinal o trabalho de que se fala é o trabalho produtivo.

${ }^{55}$ Entendendo por isto a concepção de que o trabalho abstrato é o gasto de trabalho que existe em qualquer época histórica.

${ }^{56}$ Como vimos, John Weeks e Michael Eldred tiraram de maneira radical as conseqüências deste corte.
} 
forma consistente a determinação do trabalho abstrato na produção ${ }^{57}$; isto não elimina, contudo, as ambigüidades da sua argumentação.

A posição de Rubin tem um outro problema mais geral que é útil comentar, pois isto permite esclarecer melhor o sentido dos conceitos de trabalho abstrato e de valor: é a própria concepção do que é a Economia Política (e portanto a teoria do valor).

Já na "Introdução" do seu livro [Rubin 1980, pp. 13-6], Rubin propõe uma divisão no estudo da economia capitalista entre a "ciência da engenharia social" e a Economia Política. A primeira (ainda em "estado embrionário") deve analisar "as forças produtivas da sociedade", enquanto "a Economia Política teórica trata das relações de produção específicas da economia capitalista, na medida em que interagem com as forças produtivas da sociedade" [Ibidem, p. 14]. E continua:

Cada uma destas duas ciências, lidando com apenas um aspecto de todo o processo de produção, pressupõe a presença do outro aspecto deste processo, na forma de um suposto subjacente à investigação. Em outras palavras, muito embora a Economia Política trate das relações de produção, ela sempre pressupõe seu vínculo inquebrantável com o processo de produção técnico-material, e em sua investigação supõe um estágio e um processo concretos de modificação das forças produtivas materiais [Rubin 1980, p. 14].

Há vários problemas com esta concepção da divisão dos estudos da economia capitalista. O mais óbvio é que uma "ciência da engenharia social" não existe nem mesmo em estado embrionário, e é duvidoso que possa vir a existir como uma ciência separada ${ }^{58}$. O segundo problema é que, como observa Diane Elson [1979, p. 124], embora fale que cada ciência pressupõe a outra, Rubin trata o desenvolvimento técnico-material (também chamado de "desenvolvimento das forças produtivas") como um processo autônomo, que influencia as "relações de produção", consideradas o campo específico da Economia Política sem ser influenciado por elas. Trata-se de um esquema demasiado mecânico, e mais: ao excluir os aspectos técnico-materiais do campo da ciência econômica, Rubin tende a vêla como uma ciência da distribuição. Diane Elson [1979, p. 125] cita uma passagem do

\footnotetext{
${ }^{57}$ Como vimos na subseção 3.3.3.

${ }^{58}$ É bem claro, aliás, que Marx não fazia esta separação, como atestam os capítulos sobre a produção da mais-valia relativa do Livro I, em que as análises das relações capitalistas e das suas repercussões nos processos técnico-materiais se mesclam completamente.
} 
Capítulo 8 de A Teoria Marxista do Valor (cujo título é, significativamente, "As Características Básicas da Teoria de Marx sobre o Valor") que deixa isto claro:

O objeto da teoria do valor é a inter-relação das diversas formas de trabalho no processo de sua distribuição, estabelecidas através da relação de troca entre as coisas, isto é, entre os produtos do trabalho [Rubin 1980, pp. 82-3].

De fato, todo o livro de Rubin trata da teoria do valor como uma teoria da distribuição do trabalho social, do equilíbrio da distribuição do trabalho na economia capitalista ${ }^{59}$. Esta é mais uma razão que explica que muitos autores encontrem apoio em sua obra para centrar os conceitos de trabalho abstrato e conseqüentemente de valor na troca, e para tratarem-nos como categorias da distribuição — embora o próprio Rubin não o faça.

Moishe Postone critica esta concepção do valor como categoria da distribuição chamando a atenção para o fato de que a constituição do trabalho abstrato, o desenvolvimento do valor até o capital, o desdobramento do processo de trabalho em processo de trabalho material e processo de valorização, modificam o caráter do processo de produção (a produção de valores de uso é subordinada à produção de valor) e suas condições técnicas. A necessidade de pautar a produção pelo tempo de trabalho socialmente necessário e de reduzi-lo - molda o processo de trabalho, como vimos na subseção 1.4.3. No Capítulo 5 veremos que, muito mais do que uma lei do equilíbrio na distribuição social do trabalho, a lei do valor é uma lei da minimização do tempo de trabalho. O quantum de trabalho abstrato não é determinado no momento de cada troca; a necessidade de vender os produtos em condições competitivas obriga à contagem do tempo de trabalho (na forma do cálculo dos seus custos) e ao seu controle na própria produção, e de uma maneira tão forte que todo o processo é transformado em função disto. O trabalho abstrato é, sem dúvida, uma categoria da produção, e o mesmo acontece com o valor.

\subsection{9 - Trabalho abstrato e determinação social do valor}

Finalmente, uma última questão deve ser mencionada nesta seção. Vimos, nas subseções de 3.3.3 a 3.3.6 que o tempo de trabalho concreto, ao se transformar em tempo de trabalho abstrato (socialmente necessário), sujeita-se a diversas reavaliações sociais, com

\footnotetext{
${ }^{59}$ Como veremos no Capítulo 5, isto o leva à compreensão da lei do valor como "lei do equilíbrio da economia mercantil" [Rubin 1980, p. 82], o que reduz o significado desta lei.
} 
a conseqüência de que as "horas abstratas" não correspondem exatamente às "horas físicas" de trabalho. Não seria preferível, então, abandonar a referência ao trabalho, ficar apenas com a noção de que o valor é uma magnitude definida socialmente? Não evitaríamos com isto várias dificuldades, e uma certa "artificialidade" de falar em um tempo de trabalho que não é o tempo de trabalho concreto, efetivo?

A resposta a estas questões, naturalmente, é negativa; o conceito de valor se enraíza na produção, o trabalho abstrato se vincula ao trabalho concreto. A magnitude do trabalho abstrato (e, portanto, do valor) depende, sim, de reavaliações sociais; mas seu ponto de partida é o tempo fisico de trabalho, e esta é, de qualquer maneira, sua referência fundamental.

É por isto que aquela que podemos chamar de versão simplificada do valor-trabalho ${ }^{60}$ tem uma grande força empírica, como nos lembram por exemplo Anwar Shaikh e E. Ahmet Tonak [Shaikh 1984, Shaikh e Tonak 1994, Shaikh 1998a]. No artigo de 1984, após rever vários estudos empíricos a respeito, Shaikh observa que:

Em geral, tanto para preços de produção como para preços de mercado, a porcentagem típica de desvio (a soma dos valores absolutos dos desvios dividida pela soma dos preços) é moderada: para os dados de preços de produção, é da ordem de $\pm 17-19 \%$; e para os preços de mercado, é da ordem de $\pm 20-25 \%$ [Shaikh 1984, p. 78].

Shaikh e Tonak citam outros estudos em que os desvios típicos são ainda menores [1994, p. 143]. E em trabalho publicado em 1998, cujo título é justamente "The Empirical Strength of the Labour Theory of Value", Shaikh concluiu:

(...) [E]ncontramos que na média valores-trabalho se desviam de preços de mercado apenas $9,2 \%$, e que os preços de produção (calculados segundo a taxa de lucro observável) se desviam dos preços de mercado apenas 8,2\% [Shaikh 1998a, p. 243].

\footnotetext{
${ }^{60}$ Por "versão simplificada do valor-trabalho" entendemos os cálculos empíricos dos valores que são feitos com base na soma de horas trabalhadas por setor. A razão de chamarmos estes cálculos de "versão simplificada" é que eles não podem, com os dados empíricos disponíveis, levar em conta todas as reduções necessárias à passagem do tempo de trabalho concreto a tempo de trabalho abstrato (socialmente necessário). Especialmente delicada é a redução do trabalho complexo a trabalho simples.
} 
Se os desvios dos preços em relação à "versão simplificada dos valores" são moderados, podemos concluir que as quantidades de trabalho são o determinante empírico mais importante dos preços.

Outro argumento para provar a força explicativa da teoria do valor-trabalho é utilizado por Angelo Reati [1989]. Baseando-se no modelo de Pasinetti [1981], raciocinando em um contexto dinâmico, Reati mostra que o aumento da produtividade do trabalho leva ao declínio dos preços de produção. Ora, aumento de produtividade do trabalho tem por definição uma relação inversa com os valores-trabalho. “(...) [A] tese de Marx de que os preços de produção são governados pelos valores parece teoricamente provada" [Reati 1989, p. 171]. Naturalmente, os preços de produção são conceitos teóricos, e cabe mostrar que têm capacidade de explicar os preços de mercado. Os trabalhos de Shaikh e Tonak citados acima tratam também desta questão. Reati, contudo, no artigo citado, está polemizando com os neo-ricardianos que defendem o abandono dos valores como redundantes ${ }^{61}$, em favor da utilização dos preços de produção, razão pela qual a demonstração do vínculo entre valor e preço de produção lhe basta.

\section{4 - A SUBSTANCIA DO VALOR}

\subsection{1 - Por que substância?}

No parágrafo de $O$ Capital que introduz os conceitos de valor e de trabalho abstrato $^{62}$ [O Capital I-I: 47; El Capital: I-I: 47], as expressões usadas para caracterizar a substância social comum aos valores são sugestivas: objetividade fantasmagórica, simples gelatina de trabalho humano indiferenciado. O trabalho abstrato é chamado de "substância constituidora do valor"63 [O Capital I-I: 47; El Capital: I-I: 48]. Expressões semelhantes se repetem: um pouco adiante, Marx volta a usar a figura da gelatina: diz que os valores são gelatinas homogêneas de trabalho [O Capital I-I: 52; El Capital: I-I: 55]. Lembra que a objetividade [das mercadorias] como valores é puramente social, que "não se encerra ne-

\footnotetext{
${ }^{61}$ Como mencionamos adiante, no Capítulo 4.

${ }^{62}$ Reproduzido na subseção 1.2.1.

${ }^{63}$ A edição Siglo Veintiuno Editores prefere “substância geradora do valor”.
} 
nhum átomo de matéria natural na objetividade de seu valor" [O Capital I-I: 54; El Capital: I-I: 58]. Diz ainda que cada mercadoria, “(...) como valor, é apenas um invólucro reificado do trabalho humano nela despendido" [O Capital I-I: 83; El Capital: I-I: 111]. Enquanto valor, a mercadoria é uma "massa de tempo de trabalho solidificado" [O Capital II: 150; El Capital: I-I: 230]. Estas expressões se repetem ao longo de $O$ Capital, e nas outras versões do mesmo texto (em Para a Crítica da Economia Política e na sua versão primitiva, nos Grundrisse).

Naturalmente, a afirmação de que o valor é a objetivação de uma substância social, na qual não há nenhum átomo de matéria natural, representa um uso pouco comum da expressão "substância". Mas não há dúvida de que este é um elemento importante da teoria de Marx.

Qual a razão para tratar o valor como substância social?

Uma primeira razão pode ser considerada clara: falar de uma substância, de um conteúdo que se expressa na troca é uma maneira de dizer que o valor não se reduz a uma simples relação de troca, e que não é tampouco uma realidade simplesmente subjetiva. Como observa Ruy Fausto, com o termo "substância" Marx assinala que o trabalho abstrato ganha o caráter de uma coisa, embora coisa social; ele "quer dizer com isto que o trabalho é coisa social, ele tem a espessura, o peso da coisa" [Fausto 1983c, p. 100]; "ele não é uma relação que os agentes estabelecem subjetivamente" [idem, p. 131, nota 43] ${ }^{64}$. Marx não fala apenas de substância, mas de substância social, sem nenhum átomo de matéria; vimos, no Capítulo 1, que isto se liga à compreensão de que as categorias econômicas são formadas a partir da reificação das relações sociais.

Esta abordagem tem grandes vantagens conceituais e analíticas. Enumeremos algumas delas, destacadas ao longo desta tese.

\footnotetext{
${ }^{64}$ Esta é a primeira das determinações da noção de substância, tal como usada por Marx para se referir ao valor, segundo Ruy Fausto. As duas outras são a forma fluida e a oposição a sujeito (ao capital, a substância que se tornou sujeito). [Fausto 1983c, pp. 100-1]. "O valor é coisa, ele é coisa fluida, ele é coisa que só é, ainda, num primeiro nível de sua autonomização (se se comparar com a coisa social capital: a substância que se tornou sujeito)" [Idem, p. 131, nota 43].
} 
1. Torna possível desenvolver uma teoria do dinheiro como representação material de uma substância social (imaterial), o trabalho humano abstrato.

2. Torna possível desenvolver uma teoria do capital como substância social semovente, que subordina os indivíduos a seu movimento. O conceito de substância permite reproduzir conceitualmente algo que tem clara existência real: as metamorfoses do valor, particularmente importantes para o tratamento do capital.

3. Torna possível falar das variações no tempo de uma substância: isto abre grandes possibilidades para o tratamento da dinâmica.

4. Dá condições mais adequadas para falar do valor (e dos preços) fora de situações de equilíbrio.

5. Permite tratar de uma maneira coerente a distinção entre valores e preços e, portanto, as transferências de valor na circulação, o que traz vantagens que serão mostradas no Capítulo 5.

\subsection{2 - As críticas}

A teoria do valor de Marx tem sido objeto de críticas muito diversas; algumas se centram no conceito de substância do valor.

Cornelius Castoriadis, por exemplo, atribui-lhe um caráter metafísico:

O primeiro capítulo do Capital é metafísico. A questão colocada pela economia política clássica: por que os objetos trocados o são em tal proporção e não numa outra, Marx a reformula a seu modo, numa formulação que já contém, ou predetermina, a resposta: 'Qual é o igual/ idêntico (das Gleiche), isto é, a substância comum (die gemeinschaftliche Substanz) que a casa representa para a cama na expressão do valor da cama?' Reformula-a a seu modo: o valor-trabalho dos clássicos, de Smith e de Ricardo, não invoca a categoria da 'substância' e se aí se descobrisse a palavra, seria sem dúvida num emprego inocente. Que as mercadorias são trocadas em proporção ao trabalho que sua produção custa, isso quer dizer para os clássicos: se alguém me propusesse trocar um produto que me custou dez horas de trabalho por um de seus produtos cuja fabricação só me custaria nove horas de trabalho, eu recusaria sua proposta; e, mediante a concorrência, a relação dos respectivos tempos 'médios' de trabalho regulamentará a relação das quantidades trocadas. O 'valortrabalho' é assim, antes das imensas (e insuperáveis) complicações criadas pelas diferenças 
dos trabalhos individuais, pelo 'capital', pela 'terra', pelo 'tempo', etc., um assunto de bom senso e mesmo uma tautologia simples: quem daria dez para ter nove?

Marx reformula a questão a seu modo - que a põe de uma vez no campo da tautologia metafísica. [Castoriadis 1987, p. 268].

Maurice Lagueux e Philip Mirowski desenvolvem outro aspecto da crítica à noção de substância do valor.

Lagueux [1985] argumenta que Marx teria incorporado à sua teoria do valor princípios de conservação, e conseqüentemente um conceito de substância, seguindo hábitos mentais da ciência do século XIX (explicações científicas com base em princípios de conservação foram desenvolvidas na Física desde Descartes, que falou da conservação da quantidade de movimento do universo, até o século XIX, em que o destaque foi da idéia de conservação da energia, passando pelo princípio da conservação da matéria, atribuído a Lavoisier; já a Física do século XX, a partir dos trabalhos de Poincaré, entre outros, adotou uma visão crítica destes princípios). A noção de substância de Marx seria fundamentalmente a mesma da Física. Se ele assinalou que não há no valor "nem um átomo de matéria", "isto significa apenas que o valor é concebido como substância de uma ordem diferente da matéria, um pouco da maneira que os físicos do século XIX concebiam a energia como uma 'substância sem peso"” [Lagueux 1985, p. 116].

Segundo Lagueux, o exemplo mais importante da utilização de princípios de conservação em $O$ Capital é a solução do problema da transformação no Livro III ${ }^{65}$; por isto, a demonstração de que a conservação do valor (ou seja, as "duas igualdades" — soma dos valores e soma dos preços, soma das mais-valias e soma dos lucros) é impossível abala toda a construção teórica. De qualquer maneira, não há que lamentar este fato, pois a ciência, desde o século XX, dispensa este tipo de princípio.

O ponto de vista de Mirowski [1989] é bastante semelhante, embora faça uma discussão muito mais ampla do papel dos princípios de conservação na ciência em geral e na ciência econômica em particular, e embora o centro de sua crítica seja a teoria neoclássica,

\footnotetext{
${ }^{65}$ Que não foi publicado por Marx, como é bem conhecido; Lagueux acredita que isto se deve a Marx não ter ficado satisfeito com a solução, como provariam os "reconhecimentos de erros" nesta questão que comentaremos no Capítulo 4, com uma interpretação muito diferente da de Lagueux.
} 
vista como adaptação precária da Física da energia de meados do século XIX às questões econômicas ${ }^{66}$.

Para Mirowski, Marx é o último grande representante das teorias do valor como substância, desenvolvidas de modo diferenciado pelos mercantilistas, pelos fisiocratas e pelos economistas clássicos britânicos, cuja grande referência na Física seria a concepção cartesiana da substância em movimento. As características gerais destas teorias podem ser assim resumidas:

O valor era reificado como uma substância conservada, conservada na atividade de comércio para prover estabilidade estrutural aos preços, e especificada diferenciadamente no processo de produção. (...)

Esta concepção "clássica" dividia grosso modo o mundo em três categorias exaustivas: produção, circulação e consumo. A produção tornou-se associada com qualquer atividade ou lugar onde a suposta substância do valor era criada ou aumentada de acordo com princípios naturais fixos. A circulação identificava a função do comércio, que era deslocar a substância do valor entre setores, classes, ou outras categorias funcionais, sujeita à condição de que o comércio de equivalentes garantiria a conservação da substância do valor neste processo. O consumo era associado a qualquer atividade ou lugar em que a substância do valor era destruída ou diminuída [Mirowski 1989, pp. 142-3].

Mirowski acrescenta depois algumas outras características deste tipo de teoria do valor: a distinção entre produtivo/improdutivo, e "alguma justificação naturalística do valor por meio de tautologias tais como: 'Você é o que você come' (fisiocracia), 'As coisas têm valor porque as pessoas as fizeram' (Marx), etc" [Mirowski 1989, p. 399]. Além disto, vincula estas teorias à busca de algum tipo de medida invariável do valor [p. 187].

No caso que nos interessa, que é o de Marx, Mirowski lhe atribui o desenvolvimento de duas teorias do valor: "a primeira enraizada na mais antiga tradição de substância, a outra apresentando semelhanças com as nascentes teorias do campo na física" [p. $177]^{67}$. A primeira teoria é a do "trabalho-cristalizado" (incorporado) [p. 180], a segunda

\footnotetext{
${ }^{66}$ A diferença mais importante entre o argumento de Lagueux e o de Mirowiski está em que o segundo afirma que em meados do século XIX a noção de substância adotada por Marx já tinha sido ultrapassada há muito na Física; esta é uma das razões, segundo ele, que levaram Marx a construir uma teoria incoerente.

${ }^{67}$ Mas seriam os neoclássicos que desenvolveriam toda sua teoria com base no conceito de campo.
} 
do "custo-real" [p. 180-1]. Esta segunda versão, segundo Mirowski, ao afirmar a modificação da magnitude dos estoques de valor a partir de mudanças técnicas (como vimos na subseção 3.3.5) ou ainda de fenômenos de mercado ${ }^{68}$, estaria em direta contradição com a abordagem do trabalho cristalizado e com a idéia de uma substância do valor [p. 181]. Sua semelhança com as teorias do campo na Física viria de que "[n]esta visão, só se pode dizer que uma mercadoria tem valor em relação com a configuração contemporânea da produção" [p. 181] ${ }^{69}$.

Mirowski não dá o destaque à inviabilidade de uma solução para o problema da transformação o mesmo peso que Lagueux; no entanto, é importante assinalar que também para ele este é um dos argumentos que mostram a falta de sustentação da teoria do valorsubstância.

Outro autor que comenta criticamente as referências feitas por Marx à existência de uma substância do valor é Geert Reuten [1993]. Apoiando-se em parte em Mirowski, afirma que este termo é uma metáfora que prejudicou significativamente a teoria marxista do valor [p.103], representando uma "heurística negativa" no sentido de Lakatos (levaria ao foco da teoria do valor mais em entidades físicas do que em formas sociais) [p. 104]. Enfatiza a importância de libertar-se deste conceito [p. 109].

Tal como os outros autores citados, Reuten relaciona a noção de substância do valor, aplicada à transformação dos valores em preços de produção, com os princípios de conservação da Física clássica. Interpreta que seu sentido seria então o de "uma noção de conservação desta substância (...) transmitida de um nível (analítico) de abstração para o próximo", e critica esta idéia [Reuten 1993, p. 103-4]. Como veremos no Capítulo 4, esta interpretação é incorreta: a transformação dos valores em preços de produção é um processo que se realiza no mesmo nível de abstração, e não de um nível para o próximo.

\footnotetext{
${ }^{68}$ Aqui ele se refere a mudanças a partir de variações de preços, que discutiremos no Capítulo 5.

${ }^{69}$ Um tanto fora da questão do caráter de substância do valor, Mirowski atribui a Marx, de modo completamente absurdo, a concepção do dinheiro como um "véu” [p. 178]. Como é bem sabido, Esta é uma posição de alguns "clássicos" (Ricardo) e dos neoclássicos em geral, e de modo algum de Marx. Pelas citações que faz para justificar tal afirmação, que se referem a uma sociedade socialista, vemos que a confusão de Mirowski veio de que não percebeu que o que poderia valer para o socialismo (em que não existiria valor, e portanto tampouco dinheiro propriamente) não vale para o capitalismo.
} 
Vemos, portanto, que críticas à idéia de uma substância do valor são feitas inclusive por autores que, como Reuten, colocam-se em geral no interior da tradição marxista; e que um dos pontos centrais dos que criticam a teoria de Marx a partir deste ângulo é sua relação com princípios de conservação (semelhantes aos da Física clássica) que seriam inviabilizados a partir do fracasso da transformação dos valores em preços de produção segundo o procedimento proposto por $\operatorname{Marx}^{70}$. Veremos, no Capítulo 4, que o tratamento da transformação dos valores em preços de produção é um argumento a favor da noção de uma substância social do valor.

\subsection{3 - Avaliação das críticas}

Em primeiro lugar: falar em substância do valor seria retroceder à velha metafísica?

Ruy Fausto responde a esta questão da seguinte maneira:

Os que afirmam que Marx é metafísico crêem em geral que a resposta de Marx a uma crítica como esta seria defensiva; ele diria que seu discurso não tem nada de metafísico, que ele é científico no sentido corrente etc. Na realidade, a idéia de que é um defeito para um discurso ter alguma coisa de metafísico está subjacente a toda esta argumentação. (...) Ora, a resposta que Marx daria - a resposta que ele dá, pois o argumento já se encontra, por exemplo, em Bailey - é totalmente diversa. Por um lado, ele reconhece que seu discurso tem algo de metafísico. Mas a metafísica de seu discurso é a reprodução da metafísica do real. É o real, o capitalismo, que é em certo sentido metafísico, e o discurso quase metafísico é por isso o verdadeiro discurso científico, assim como o discurso "claro" da ciência se torna neste caso inadequado. Marx sempre insistiu no fato de que por exemplo a mercadoria tem algo de misterioso, que ela é um objeto sensível supra-sensível etc. Para apreender esse tipo muito particular de objeto, é necessário um discurso que se ajuste a ele, isto é, um discurso que ponha essas abstrações objetivas como elas são efetivamente: como coisas sociais que reduzem os agentes a suportes [Fausto 1983c, p. 101].

\footnotetext{
${ }^{70}$ Outros autores marxistas que tocam no mesmo ponto e reproduzem estes argumentos são Marco Lippi [1979a, Capítulo 3] e Fernando Vianello [1979].
} 
Sem entrar em todos os aspectos desta argumentação ${ }^{71}$, podemos dizer que, nesta resposta, Fausto captou o ponto fundamental para a questão em pauta aqui: Marx não inventou o caráter de substância do valor (nem os aspectos misteriosos, sensíveis supra-sensíveis, da mercadoria); reproduziu um dado da realidade, um resultado da prática social dos agentes econômicos. Mirowski fala diversas vezes que o uso do conceito de substância representa uma reificação de certas experiências, realizada pelo teórico que busca compreendê-las. Mas, na realidade, quem gera esta reificação é a prática social! Se não captarmos esta reificação na teoria, esta não reproduzirá todo o real.

Tratar relações sociais (valor, dinheiro, capital - as categorias da economia em geral) como substâncias - uma palavra que em geral se refere ao "estofo material" das coisas — é sem dúvida atribuir-lhes conceitualmente um caráter algo místico. Marx identificou claramente que era justamente isto o necessário para apreender teoricamente estas relações sociais. Por isto, como Castoriadis percebeu corretamente, empregou a idéia de substância de modo muito mais consciente, forte e explícito do que o fizeram os economistas clássicos.

Avaliando a segunda vertente da crítica — a de que a noção de substância está vinculada a princípios de conservação ultrapassados — , podemos dizer que, num certo sentido, Marx fez justamente o contrário do que críticos como Lagueux, Mirowski ou mesmo Reuten afirmaram. Na teoria do valor de Marx, a idéia de que o valor é uma reificação, uma fetichização de relações sociais não é um detalhe; é o tema central. Longe de querer ver na substância do valor algum tipo de éter, uma substância física sem peso (este era o caráter atribuído ao éter), Marx insiste em que ela é uma substância, por assim dizer, plenamente social, embora assuma a forma de uma propriedade das coisas ${ }^{72}$.

É por isto que não há a incoerência entre as supostas duas versões da teoria do valor propostas por Mirowski. A noção de trabalho abstrato objetivado nas mercadorias, referindo-se a uma realidade social, é perfeitamente consistente com reavaliações dos estoques

\footnotetext{
${ }^{71}$ A impossibilidade de dar conta de uma realidade contraditória (obscura) através de conceitos "claros" é o tema central de outro ensaio de Ruy Fausto [1987b]. A tese de Leda Paulani [1991] trata de forma ampla de como esta questão se apresenta na ciência econômica, e em particular na compreensão teórica do dinheiro.

${ }^{72}$ E embora resulte do desdobramento do trabalho em concreto e abstrato, guardando portanto uma relação com o trabalho concreto, com o trabalho como realidade material (como vimos na subseção 3.3.3).
} 
de valor existentes realizadas socialmente; isto está claramente incluído no conceito de trabalho socialmente necessário. Mais que isto, Marx chama explicitamente a atenção para o caráter variável da medida do valor pelo tempo de trabalho abstrato desde a discussão do duplo caráter do trabalho no Capítulo I do Livro I de O Capital (como vimos no Capítulo 1, subseção 1.2.1, e na subseção 3.2.4 deste capítulo). Ou seja, o valor é medido com um "metro" que é ele mesmo variável.

O único princípio de conservação realmente defendido por Marx é o de que a troca enquanto tal não cria ou destrói valor (embora possa ser desigual e, portanto, realizar uma transferência de valor). Esta concepção tem de fato implicações fundamentais para a transformação dos valores em preços de produção. Mas além de a produção criar valor e o consumo destruí-lo, reavaliações a partir de mudanças tecnológicas também podem aumentálo ou reduzi-lo (este último tema será retomado no Capítulo 5). O valor pode ser destruído, pode desaparecer completamente mesmo fora da esfera do consumo.

Marx, naturalmente, era filho do seu tempo; é perfeitamente razoável dizer que raciocinava a partir dos conceitos de ciência da sua época, ou até de épocas anteriores. A questão, porém, é que seu tratamento da questão do valor representou uma subversão de conceitos então vigentes.

Mirowski, contrapondo-se tanto à teoria do valor-trabalho quanto à da utilidade marginal, defende uma teoria social do valor:

A última alternativa, que não descrevemos neste volume, pode ser chamada de 'teoria social do valor'. A razão pela qual não a descrevemos aqui é que o traço característico deste programa é a recusa de fundar qualquer princípio de conservação em metáforas naturais ou científicas. Isto não significa que esta teoria do valor evite todas as invariâncias; ao contrário, ela tende a situá-las em instituições sociais, tais como as instituições das convenções de contabilidade (digamos, Werner Sombart ou David Ellerman) ou na definição legal de direitos de propriedade (John R. Commons), ou ainda no próprio dinheiro (Knapp e a Escola Histórica Alemã) [Mirowski 1989, p. 400].

O contexto deixa claro que Mirowski se identifica com uma teoria deste tipo.

Ora, a teoria de Marx é uma 'teoria social do valor', e não funda qualquer princípio de conservação em "metáforas naturais ou científicas": o conceito de valor de Marx, como vimos, funda-se na prática social das classes sociais. Ele buscou reproduzir conceitualmente a reificação das relações sociais, e explicar por que ocorre; e ainda chamou a aten- 
ção para a determinação social da magnitude do valor. Neste sentido, Marx está muito mais distante do "naturalismo" do que os sraffianos, que determinam os preços a partir apenas de dados tecnológicos. A teoria do valor marxiana é sem dúvida diferente das concepções demasiado convencionalistas que Mirowski favorece (determinação do valor a partir de convenções de contabilidade, de definições legais de direitos de propriedade), ou de fundar o valor no dinheiro (o que seria, para Marx, uma clara inversão da relação); mas é sem dúvida uma fundação social. Marx é um antinaturalista ${ }^{73}$.

Nada poderia estar mais distante da teoria de Marx do que o "naturalismo". Na verdade, esta crítica se explica antes por uma confusão: a suposição de que Marx funda o valor no papel trans-histórico fundamental do trabalho na produção. Como vimos na seção 3.3 deste capítulo, esta suposição é incorreta.

Resta a crítica da "heurística negativa". No sentido dado por Reuten — de que falar em substância (social!) do valor induziria a dar mais importância a entidades físicas do que a formas sociais -, esta crítica não pode ser aceita. O que seria difícil recusar seria uma crítica um tanto diferente: a de que a complexidade e a sofisticação da argumentação de Marx facilita entendimentos incorretos ${ }^{74}$.

Por outro lado, como argumentamos ao fim da subseção 3.4.1, a noção de substância do valor tem vantagens conceituais e analíticas.

\subsection{4 — Esta substância existe ?}

Mas afinal, a questão-chave nesta discussão deveria ser: isto que Marx chama de substância social existe ou não? Há traços empíricos da sua existência?

É possível afirmar que sim, traços da existência desta substância social podem ser detectados em comportamentos observáveis. Ou seja: para trocar (vender, comprar) merca-

\footnotetext{
73 O que não significa que negue as bases materiais da fundação social do valor. Mas falar em bases materiais não é o mesmo que falar em bases naturais.

${ }^{74}$ Ponto destacado por Postone, e que é reforçado por um exemplo de entendimento incorreto do argumento de Marx oferecido pelo próprio Postone: como vimos na subseção 3.3.7, este autor se equivoca quando afirma o caráter "descontextualizado" da caracterização do trabalho abstrato no Capítulo I de O Capital. Só nos resta esperar que esta tese não propicie demasiados exemplos do mesmo ponto.
} 
dorias as pessoas em geral as comparam com uma terceira, o dinheiro; não trocam comparando diretamente utilidades, mas muito mais atribuindo às mercadorias valores e comparando-os. Deste comportamento que introduz uma mediação na comparação de utilidades, vimos que o dinheiro nasce diretamente. Assim, é possível considerar a existência do dinheiro uma comprovação indireta da realidade do valor como substância social. Além disto, existem claramente situações em que um agente ganha e o outro perde numa troca, em que há uma transferência de valor, o que também supõe a existência de uma substância. As noções de valor como coisa social, bem como a do dinheiro como meio para expressar o valor, são realidades sociais práticas. O mesmo acontece com as metamorfoses do capital, que só têm sentido diante da existência de uma substância que assume várias formas.

Para concluir esta seção: falar em substância do valor é fazer uma metáfora? Mas em qual sentido?

Não há dúvida de que, num certo sentido, falar do valor como substância é uma metáfora: afinal, substância remete em geral a um conteúdo material. Isto não significa, porém, que a existência desta substância seja uma ficção; significa apenas que sua realidade é social, e não material. Uma realidade social, contudo, não é menos real que realidades físicas. 


\section{CAPÍTULO 4 - O PROBLEMA DA TRANSFORMAÇÃo ${ }^{1}$}

\section{1 - INTRODUÇÃo}

Um dos temas de discussão mais tradicionais da economia marxista é o chamado problema da transformação dos valores em preços de produção. A opinião que ainda prevalece é a de que ele não pode ser resolvido em termos satisfatórios para o quadro teórico marxiano; este é mesmo um dos argumentos mais usados para diminuir a validade teórica deste quadro ${ }^{2}$. Há, contudo, maneiras perfeitamente satisfatórias de tratar a transformação dos valores em preços de produção. Neste capítulo é apresentada uma delas: a abordagem que vem sendo chamada pelos seus proponentes de sistema único temporal, ou de abordagem não dualista e temporal. Esta abordagem pode ser considerada uma decorrência direta da concepção de que o valor tem uma substância social, o trabalho abstrato; a apresentação feita aqui representa, portanto, uma maneira de exemplificar uma vantagem desta concepção.

Os principais trabalhos na linha do Sistema Único Temporal são: Kliman e McGlone [1988; 1999]; Freeman [1995]; Kliman [1998] e vários capítulos do livro Marx and Non-Equilibrium Economics [Freeman, Alan and Carchedi, Guglielmo (eds.) 1996] ${ }^{3}$. A designação sistema único temporal foi usada em vários trabalhos destes autores apresentados na Mini-Conferência do International Working Group on Value Theory, Washington DC, USA, abril de 1997. Também são importantes nesta linha de pesquisa os

\footnotetext{
${ }^{1}$ Uma versão anterior de parte deste capítulo foi apresentada na mesa especial da ANPEC O Atual e o Inatual em Marx, em 1997, e publicada na Revista da ANPEC n 1, 1997, pp. 73-101, com o título: “O Sistema Único Temporal: Uma Nova Abordagem da Transformação dos Valores em Preços de Produção".

${ }^{2}$ Em especial, o argumento da inviabilidade da transformação nos termos propostos por Marx é usado para mostrar a impossibilidade de tratar o valor como substância, como vimos no Capítulo 3, seção 3.4.

${ }^{3}$ No Brasil, Eduardo Maldonado-Filho apresentou já em 1987, na ANPEC, um trabalho que apontava para a mesma abordagem.
} 
trabalhos que formularam a transformação em um sistema único simultâneo ${ }^{4}$ : Wolff, Roberts and Callari [1982; 1984; 1998] e Moseley [1993b; 1998; 2000].

O problema da transformação tem origem na necessidade de compatibilizar a teoria do valor desenvolvida no Livro I de $O$ Capital com a tendência, que deve prevalecer na economia capitalista, de as taxas de lucro se igualarem. Se as composições orgânicas e os tempos de rotação dos capitais são em geral distintos, a venda das mercadorias pelos seus valores (na média) levaria a taxas de lucro estruturalmente desiguais entre os vários setores, já que a porção de mais-valia de que cada capital se apropria é proporcional apenas ao capital variável, e não a todo o capital e tampouco a seu tempo de rotação. Uma tal desigualdade estrutural nas taxas de lucro seria claramente absurda.

Marx acreditou ter resolvido esta questão com a transformação dos valores em preços de produção, descrita na Seção II do Livro III de O Capital, especialmente no Capítulo IX. Sua solução, contudo, imediatamente após a sua divulgação, em 1894, começou a receber críticas ${ }^{5}$. As mais influentes foram as feitas nos artigos de Ladislaus von Bortkiewicz, publicados em $1906-7^{6}$. Na verdade, eles moldaram toda a discussão contemporânea sobre a questão da transformação dos valores em preços de produção ${ }^{7}$. E definiram uma abordagem da questão que, como é desenvolvido adiante, contribuiu para que se generalizasse a opinião de que a teoria do valor-trabalho tem sérios problemas.

A abordagem do sistema único temporal reivindica ter mostrado que o problema da transformação pode ser resolvido nos termos em que Marx o havia colocado; e que Marx, na verdade, já o havia solucionado em seus aspectos essenciais. Segundo esta abordagem, as críticas habitualmente feitas ao "algoritmo" usado no Capítulo IX do Livro III d'O Capital explicam-se menos pela inconsistência lógica do procedimento de Marx e mais pela

\footnotetext{
${ }^{4}$ Esta designação não costuma ser utilizada pelos próprios proponentes desta abordagem; é atribuída a eles pelos que defendem o Sistema Único Temporal.

${ }^{5}$ Um dos primeiros críticos foi Böhm-Bawerk [1974; 1986].

${ }^{6}$ Bortkiewicz, Ladislaus von [1952 e 1974].

${ }^{7}$ Isto não ocorreu apenas graças às suas qualidades próprias, mas sobretudo por sua divulgação ter sido impulsionada por um dos economistas marxistas mais influentes do pós - Segunda Guerra, Paul Sweezy, a partir de seu influente manual Teoria do Desenvolvimento Capitalista, publicado pela primeira vez em inglês em 1942, e depois traduzido para diversos idiomas.
} 
dificuldade que, em geral, os críticos têm de compreender o seu método e os conceitos que ele utiliza.

\section{2 - MARX E BORTKIEWICZ}

\subsection{1 - A solução de Marx}

A transformação dos valores em preços de produção feita por Marx obedece a uma lógica muito clara.

O desafio que, pelo menos desde Ricardo, estava posto para os defensores da teoria do valor-trabalho foi definido da seguinte maneira por Engels, no prefácio ao Livro II de $O$ Capital: é preciso demonstrar

(...) como, não só sem ferir a lei do valor, mas, ao contrário, fundamentando-se nela, se pode e se deve formar uma taxa média igual de lucro [O Capital II-III: 17].

O que quer dizer "sem ferir a lei do valor, mas, ao contrário, fundamentando-se nela"?

A "lei", ou a teoria do valor, significa para Marx, em primeiro lugar, que o valor é criado pelo trabalho humano, na sua qualidade de trabalho abstrato. Ou, dizendo de outra maneira, que, na economia mercantil, o trabalho humano se objetiva como valor das mercadorias. Os preços são formas do valor ${ }^{8}$.

Dentre as decorrências desta lei, podemos citar:

a) o valor é criado na produção, pelo trabalho produtivo, e portanto a circulação não pode criar valor;

b) os ganhos das classes proprietárias, que Marx engloba na categoria genérica de mais-valia, só podem se originar do mais-trabalho, isto é, do trabalho que os trabalhadores produtivos realizam além do que é necessário para repor o que eles próprios consomem.

Como conciliar estas afirmações com o fato de, diante da concorrência, cada capital tender a se apropriar de uma quantidade de mais-valia proporcional à sua magnitude total, e não apenas à parcela que adquire a força de trabalho?

\footnotetext{
${ }^{8}$ No Capítulo 5 discutimos mais amplamente o significado da lei do valor.
} 
Marx se utiliza de alguns "graus de liberdade" que haviam ficado de sua análise do processo de formação do valor e da mais-valia no Livro I: a circulação não pode criar valor mas, além de realizá-lo, isto é, transformá-lo de potencial em efetivo, pode transferi-lo, redistribui-lo. Quando se vendem as mercadorias, não é necessário que seus preços correspondam sempre exatamente ao seu valor. Pelo contrário, em geral eles não coincidem. Os preços podem ficar acima ou abaixo, o que significará que haverá ganho ou perda de valor em relação ao resultado da produção de cada mercadoria. O que é necessário, para que não haja violação da "lei do valor", ou seja, para que não haja criação de um valor novo na circulação, é que a soma dos valores seja igual à soma dos preços ${ }^{9}$. Os preços devem obrigatoriamente identificar-se com os valores no global, mas não em cada caso particu$\operatorname{lar}^{10}$.

Assim, transformar os valores em preços de produção significa definir preços que se desviam dos valores de modo a redistribuir o valor já produzido, levando à igualação das taxas de lucro. Com isto, Marx mantém todas as suas concepções básicas expostas desde o início do Livro $\mathrm{I}^{11}$. Conserva-se o quantum da substância do valor, que não pode ser alterado na circulação. A mudança que ele introduz, e que se justifica diante da necessidade de passar a tratar dos muitos capitais, e não mais do capital em geral, é considerar que os preços (de mercado) flutuam sim em torno dos valores, mas com um viés: suas médias não são dadas pelos valores, mas pelos preços de produção.

O algoritmo da transformação dos valores em preços de produção de Marx se apóia claramente nesta concepção de redistribuição de um valor já produzido, de uma substância cuja magnitude está dada. Os valores do capital constante, do capital variável e da maisvalia de todos os capitais são os dados de partida; em seguida, as mais-valias são somadas, e é obtida a massa global de mais-valia, ou seja, o lucro total. Dividindo-se o lucro total pelo capital adiantado total (capital constante adiantado + capital variável) chega-se à taxa média (geral) de lucro. Finalmente, multiplicando-se o capital adiantado de cada capital

\footnotetext{
${ }^{9}$ Supondo que o valor do dinheiro permaneça constante.

${ }^{10}$ Os "graus de liberdade" mencionados neste parágrafo são explicitados por Marx desde o início do Livro I de $O$ Capital, especialmente no Capítulo III, como vimos no Capítulo 1 (subseção 1.3.1) deste trabalho.

${ }^{11}$ Murray Smith faz uma discussão interessante sobre os "postulados básicos" da teoria do valor de Marx e sua manutenção no Livro III [Smith, Murray 1994, pp. 53 e 71-77].
} 
pela taxa média de lucro, chega-se ao lucro de que cada capital se apropria (o lucro médio), que é somado aos preços de custo (capital constante consumido + capital variável) de cada um deles para chegar aos respectivos preços de produção ${ }^{12}$.

Os preços de custo das mercadorias produzidas pelos vários capitais são invariantes na transformação, do mesmo modo que a mais-valia total. O que muda são as mais-valias (os lucros) de que cada capital se apropria, transformadas em lucro médio. Aliás, isto é bem enfatizado no próprio título da seção do Livro III que trata do assunto: A Transformação do Lucro em Lucro Médio. Naturalmente, com esta operação verificam-se as duas identidades a que Marx deu tanta importância para mostrar a coerência de sua abordagem: a soma dos valores $\equiv$ soma dos preços de produção, e a soma das mais valias $\equiv$ soma dos lucros. Além disso, só existe uma taxa média de lucro, que é calculada em valores, e usada em seguida para calcular os preços de produção. Conseqüentemente, a taxa média de lucro em preços de produção é a mesma.

As equações que expressam esta transformação são ${ }^{13}$ :

(1) $M_{i}$ (valor das mercadorias produzidas por um capital) $=c_{i}+v_{i}+m_{i}$ (capital constante consumido, capital variável e mais-valia de cada capital);

(2) $C_{i}($ capital adiantado por um capitalista $)=a_{i}($ capital constante adiantado $)+v_{i}$

(3) $k_{i}$ (preço de custo das mercadorias produzidas por um capital) $=c_{i}+v_{i}$

(4) l' (taxa geral - ou média - de lucro $)=\frac{\sum m_{i}}{\sum C_{i}}$

\footnotetext{
${ }^{12}$ Este procedimento supõe que os tempos de rotação de todos os capitais são iguais, simplificação que foi feita por Marx nos seus exemplos numéricos e seguida por Bortkiewicz, e em geral por todos os participantes desta discussão. Esta simplificação se justifica porque a necessidade de dar conta da diferença dos tempos de rotação não coloca nenhum problema adicional sério para a transformação.

${ }^{13}$ No debate sobre o problema da transformação, muitas vezes supõe-se que todo o capital constante é consumido no período de rotação, ou seja, que capital constante adiantado e capital constante consumido não se distinguem. Nas equações seguintes, não fazemos esta suposição; capital constante adiantado e capital constante consumido diferem. O primeiro inclui todo o capital constante; o segundo, apenas a parcela consumida em um período de rotação, isto é, o capital constante circulante e a parcela depreciada do capital constante fixo. Por outro lado, é feita a suposição de que o tempo de rotação dos capitais é igual a 1.
} 
(5) $l_{i}$ (lucro médio apropriado por um capitalista) $=l^{\prime} C_{i}$

(6) $P_{i}=k_{i}+l_{i}$

A partir destas equações, é fácil demonstrar que $\Sigma M=\Sigma P$ e que $\Sigma m=\Sigma l$ são duas identidades. Isto decorre diretamente do fato de a transformação dos valores em preços de produção ser uma redistribuição na circulação de parte do valor já definido na produção.

\subsection{2 - A correção de Bortkiewicz e sua lógica}

O ponto de partida da crítica de Bortkiewicz à transformação marxiana é o questionamento de sua completude, e daí de sua consistência lógica. As equações 1, 3 e 6, apresentadas acima, falhariam por não "manter separados com rigor suficiente os princípios do cálculo em valor e do cálculo em preços" (de produção) ${ }^{14}$, já que os mesmos $c$ e $v$ entram na formação dos valores e dos preços de produção; uma maneira alternativa de dizer a mesma coisa é apontar que a equação 6 mistura valores $\left(k_{i}\right)$ e preços de produção $\left(P_{i}\right)$. Portanto a transformação realizada por Marx seria incompleta, e para completá-la seria preciso transformar os insumos (o capital constante e o capital variável, $c+v$ ) em preços de produção.

Um desdobramento importante desta crítica é a afirmação de que não é possível calcular a taxa média de lucro com base no quociente da mais-valia global pelo capital adiantado global, e usá-la como base para o cálculo do lucro médio, e portanto dos preços de produção; a taxa média de lucro deve ser calculada em preços de produção, pois os bens que compõem a mais-valia (o excedente) e o capital adiantado também devem ter seus valores transformados em preços de produção; a taxa média de lucro, portanto, varia na transformação. Neste argumento, fica claro que tanto a mais-valia quanto o capital adiantado são considerados como conjuntos de bens.

Estes argumentos são reforçados com a afirmação de que o próprio Marx teria reconhecido seu erro em duas passagens do próprio capítulo de $O$ Capital em que apresenta

\footnotetext{
14 "É fácil mostrar que o procedimento empregado por Marx para a transformação dos valores em preços é errôneo, já que ele falha em manter separados com rigor suficiente os dois princípios do cálculo em valor e do cálculo em preços" [Bortkiewicz 1952: 8]. Bortkiewicz sempre se refere aos preços de produção como preços simplesmente.
} 
sua solução para o problema (e também em outros lugares), mas teria desistido de corrigi$10^{15}$.

Bortkiewicz propôs-se, então, a corrigir a formulação de Marx. O ponto de partida de sua correção é vincular a questão da transformação com os esquemas de reprodução (que supõem oferta e demanda equilibradas). Para simplificar, toma os esquemas da reprodução simples e supõe todo o capital constante consumido em um período de rotação (ou seja, supõe que não há capital fixo $)^{16}$. A partir daí, aparece um outro motivo de crítica a Marx: seu método para transformar valores em preços de produção viola o equilíbrio da reprodução [Bortkiewicz 1952, p. 9].

Marx não havia vinculado a transformação e os esquemas de reprodução; em seus exemplos numéricos do Capítulo IX do Livro III, os cinco setores em que divide a economia não pretendem abrangê-la inteiramente, e não é feita nenhuma referência a o quê cada um deles produz. Não há nenhuma suposição de equilibrio entre oferta e demanda em qualquer setor. O vínculo de transformação e esquemas de reprodução, contudo, é uma idéia bastante natural, se pensamos a transformação no interior do processo global de reprodução da economia. Mas tem uma implicação muito restritiva: a de tratar os valores e os preços de produção a partir de uma situação de equilíbrio global entre oferta e demanda; tanto os valores quanto os preços de produção têm de ser considerados constantes.

Outras hipóteses adotadas por Bortkiewicz, identificáveis já nas suas críticas ao método da transformação de Marx, e repetidas por todos os seus continuadores, afastam claramente seu modelo da teoria marxiana. Em particular, o tratamento de toda a questão num sistema de trocas diretas de mercadorias (de escambo), em que o dinheiro só é introduzido posteriormente, e de uma maneira muito particular e limitada, com a escolha de uma mercadoria qualquer como numerário. Neste quadro, o valor é apenas valor relativo, valor de troca, ou índice de uma relação de troca ${ }^{17}$; fica desprovido de sua substância (o

\footnotetext{
${ }^{15}$ Esta afirmação de que Marx "reconheceu seu erro" será comentada criticamente adiante.

${ }^{16}$ Estas simplificações podem ser dispensadas.

${ }^{17}$ Como Bortkiewicz define respondendo a uma crítica de Böhm-Bawerk a Marx [Bortkiewicz 1952, p. 12, nota 18, e também na p. 5]. Böhm-Bawerk argumentara que, sendo valores e preços apenas grandezas relativas, não há qualquer validade em comparar a soma dos valores e a soma dos preços de produção.
} 
trabalho abstrato). E, como não tem nenhuma relação necessária com o dinheiro, perde também sua forma. Além de tudo, o tempo é eliminado, e assim "os vários elementos governam uns aos outros mutuamente, e não sucessivamente”.

Esse último ponto é justificado por Bortkiewicz através de uma crítica a Ricardo e Marx. É importante reproduzi-la, pois ela lança luz também para um fato pouco conhecido — a influência de Walras sobre Bortkiewicz:

Alfred Marshall disse certa vez de Ricardo: "ele não o diz claramente, e em alguns casos talvez não tenha percebido completa e claramente como, no problema do valor normal, os vários elementos governam uns aos outros mutuamente, e não sucessivamente em uma longa cadeia de causação". Esta descrição se aplica ainda mais a Marx. (...) [Marx] manteve firmemente a visão de que os elementos concernidos devem ser olhados como um tipo de cadeia causal, na qual cada elo é determinado, em sua composição e magnitude, apenas pelos elos precedentes. (...). Seguindo as palavras citadas de Marshall, podemos chamar este traço do sistema marxiano de "sucessivismo".

A economia moderna está começando a se libertar gradualmente do preconceito sucessivista, o maior mérito cabendo à escola matemática dirigida por Leon Walras [Bortkiewicz 1952, pp. 23-24] $]^{18}$.

Com os pressupostos indicados, Bortkiewicz pôde determinar os preços de produção por meio de um sistema de equações simultâneas; a taxa média de lucro é calculada ao mesmo tempo que os preços de produção. Enfatizemos que eliminar o tempo do processo não é de nenhuma maneira um resultado de poucas conseqüências ${ }^{19}$.

Todas estas características aproximam a abordagem bortkiewicziana do modelo neoclássico de equilíbrio geral, provavelmente a partir de um esforço consciente ${ }^{20}$, e a afastam decisivamente do quadro teórico de Marx.

Em outros aspectos, Bortkiewicz se afasta do modelo neoclássico, mas não se aproxima do de Marx. Inclui a idéia de excedente, mas de um excedente concebido, como vi-

\footnotetext{
${ }^{18}$ Ao que parece, a primeira autora a chamar a atenção para esta passagem foi Michele Naples, como afirmou Alan Freeman [Freeman 1995]. Ver também Naples [1996, p. 98].

${ }^{19}$ Esta eliminação, típica dos modelos de equilíbrio geral, torna impossível, por exemplo, encontrar um lugar para o dinheiro.

${ }^{20}$ Como é sugerido pela referência a Walras reproduzida acima.
} 
mos, em termos físicos, de um conjunto de bens, e portanto bastante diferente da mais-valia (ou seja, do mais-valor) de Marx. Ao assumir a troca direta de mercadoria por mercadoria, Bortkiewicz substitui a conhecida fórmula marxiana do ciclo do capital industrial, $D-$ $M \ldots P \ldots M^{\prime}-D^{\prime}$, por uma fórmula que se resume a $M \ldots P \ldots M^{\prime}$; adota o modelo de economia que algumas décadas depois seria desenvolvido por Sraffa com o nome de produção de mercadorias por meio de mercadorias ${ }^{21}$. Este modelo é muito diferente do de Marx, que, além de enfatizar a importância do dinheiro (visto como concretização, expressão material do trabalho abstrato), coloca no primeiro plano as relações sociais.

Mas talvez o que mais distancie Bortkiewicz de Marx seja justamente seu ponto de partida fundamental: a necessidade de "manter separados com rigor suficiente os princípios do cálculo em valor e do cálculo em preços" (de produção), que o leva a distinguir rigorosamente um sistema dos valores de um sistema dos preços (de produção). Trata-se do que Ramos e Rodríguez chamaram de dualismo metodológico [Ramos-Martínez e RodríguezHerrera 1996].

Com base nestes pressupostos metodológicos, Bortkiewicz [1974] montou suas equações para três departamentos.

As equações do sistema dos valores são:

$$
\begin{aligned}
& c_{1}+v_{1}+m_{1}=c_{1}+c_{2}+c_{3} \\
& c_{2}+v_{2}+m_{2}=v_{1}+v_{2}+v_{3} \\
& c_{3}+v_{3}+m_{3}=m_{1}+m_{2}+m_{3}
\end{aligned}
$$

Para passar às equações do sistema dos preços (de produção), ele fez a razão entre o valor dos produtos e seus preços de produção para o setor $\mathrm{I}=x$, para o setor $\mathrm{II}=y$, e para o setor III $=z$. A taxa de lucro é $\rho$. Desta forma, chegou às equações:

$$
\begin{aligned}
& (1+\rho)\left(c_{1} x+v_{1} y\right)=\left(c_{1}+c_{2}+c_{3}\right) x \\
& (1+\rho)\left(c_{2} x+v_{2} y\right)=\left(v_{1}+v_{2}+v_{3}\right) y \\
& (1+\rho)\left(c_{3} x+v_{3} y\right)=\left(m_{1}+m_{2}+m_{3}\right) z
\end{aligned}
$$

\footnotetext{
${ }^{21}$ Como observou Fred Moseley [Moseley 1993b, p. 165].
} 
Como são três equações com quatro incógnitas, é possível acrescentar mais uma equação. Para que a unidade dos valores seja igual à dos preços de produção, Bortkiewicz faz $z=1$ (ou seja, escolhe a mercadoria do setor III como numerário; identifica o setor III, dos bens de luxo, com a produção da mercadoria-dinheiro - o ouro). Outras alternativas são possíveis, como o próprio Bortkiewicz mencionou, de modo a verificar $\Sigma$ valores $=\Sigma$ preços de produção, ou $\Sigma$ mais-valias $=\Sigma$ lucros. Mas como é amplamente conhecido, a partir das equações bortkiewiczianas é impossível verificar ao mesmo tempo as duas identidades, salvo em casos especiais de escasso interesse teórico. Além disso, se adotamos a mesma unidade de medida para os valores e os preços de produção, a igualdade da soma dos valores e da soma global dos preços de produção em geral não existe.

Segundo Bortkiewicz, para os que, como Marx e os marxistas, apegam-se às duas identidades, resta apenas um consolo:

Já que estão sendo comparadas, não certas magnitudes de valor e preço, mas certas relações entre magnitudes no sistema de cálculo em valores com análogas magnitudes no sistema de cálculo em preços, não ficamos de modo algum presos à condição de que a unidade de preço deva ser a mesma que a unidade de valor. Se a última é representada por 1 onça de ouro, a primeira pode ser representada por $3 / 4$ ou $1 \frac{1}{2}$ onças de ouro. Nestas circunstancias, pode-se sempre, com qualquer modelo dado de valores (...) selecionar uma unidade de preço tal que um elemento particular do modelo de preço (por exemplo, o preço do produto total de I, ou o capital variável investido em III, etc.) iguale o elemento correspondente na tabela dos valores. Do mesmo modo, não há nada que impeça que se faça a soma de certos elementos na tabela de preços coincidir com a soma dos elementos análogos da tabela dos valores, e assim, por exemplo, igualar o preço total com o valor total. Tal método de determinação só pode, obviamente, ser aplicado a uma única magnitude das listadas na tabela dos preços, ou a uma única função destas magnitudes. Não seria possível igualar simultaneamente o preço total com o valor total e o lucro total com a mais-valia total [Bortkiewicz 1952, p. 12].

O consolo de poder chegar a uma das duas identidades (mas não às duas) com o truque de mudar a unidade de medida dos preços de produção, ou seja, adotando unidades de medida diferentes para valores e preços de produção, é teoricamente duvidoso e de resultados práticos muito limitados. No entanto, este procedimento passou a ser padrão no debate sobre a transformação, dando origem por exemplo à discussão de qual das duas identidades deve ser priorizada. 
O último argumento contrário à teoria de Marx, desenvolvido a partir das equações de Bortkiewicz, é o chamado corolário de Bortkiewicz: a taxa de lucro não depende das condições de produção e da composição do capital do setor de bens de luxo (nas versões pós-sraffianas, dos setores não-básicos). Isto se deve à hipótese da igualdade das taxas de lucro e à estrutura matemática peculiar do sistema de preços de produção.

Marx havia afirmado que Ricardo confunde lucro e mais-valia, e que é por isto que acreditava que a taxa de lucro não depende das condições de produção nos setores que não produzem bens-salário ou meios de produção. Para Marx, se é verdade que as condições de produção nos setores que produzem bens de luxo não interferem na produção de mais-valia relativa, por outro lado os capitais destes setores participam ao lado dos outros na formação da taxa média de lucro [Teorias da Mais-Valia II, p. 854; no mesmo sentido, Teorias da Mais-Valia III: 1392-1394]. O corolário de Bortkiewicz dá, pois, razão a Ricardo contra Marx, e a acusação de confusão é devolvida:

São justamente estes erros aritméticos [Bortkiewicz refere-se ao suposto erro de Marx de considerar que a taxa média de lucro é a média das taxas de lucro individuais], e especialmente uma confusão entre valores e preços, que levaram Marx à sua errônea construção da taxa geral de lucro, e logo a seu injustificado ataque a Ricardo [Bortkiewicz 1952, p. 33].

Bortkiewicz, além disso, afirma que é a posição de Ricardo que reforça mais claramente a concepção, compartilhada por ele e por Marx, de que o capital não é "produtivo":

Se é de fato verdade que o nível da taxa de lucro não depende, de nenhuma maneira, das condições de produção dos bens que não entram nos salários reais, então a origem do lucro deve claramente ser buscada nas relações salariais e não na capacidade do capital de aumentar a produção. Pois se esta capacidade fosse relevante aqui, então seria inexplicável por que certas esferas da produção seriam irrelevantes para o nível dos lucros.

Em outras palavras, muito melhor do que a opinião contrária de Marx, a tese de Ricardo se ajusta à teoria que vê o lucro como dedução do produto do trabalho, isto é, à 'teoria da dedução' (como eu preferiria chamá-la, no lugar de 'teoria da exploração') [Bortkiewicz 1952, p. 33] $]^{22}$.

\footnotetext{
${ }^{22}$ Também nesta questão Sweezy endossou a posição de Bortkiewicz [Sweezy 1967, p. 152-3].
} 
Contudo, por mais este corolário reforce o argumento de que o capital não é produtivo, e com isto possa parecer simpático aos defensores da teoria do valor-trabalho, ele é inconsistente com a teoria da taxa de lucro e dos preços de produção de Marx. E suas conseqüências, em termos de interpretação do funcionamento da economia capitalista, são pelo menos estranhas. Como Ernest Mandel comenta:

Dizer que a composição orgânica da indústria de armamentos [que, tal como a produção de bens de luxo, não interfere nem na produção dos bens-salário nem na de meios de produção, e que portanto também não deveria ter importância para a determinação da taxa média de lucro - JM], incluindo seu tamanho, é irrelevante para a taxa de lucro real de uma economia capitalista real é inteiramente insustentável - especialmente se damos uma olhada no tamanho deste setor, por exemplo, na Alemanha em 1943 ou nos Estados Unidos em 1944 [Mandel 1981, p. 26-7].

Em resumo, a teoria do valor de Marx sai bastante arranhada das "correções" de Bortkiewicz.

Posteriormente as equações dos preços de Bortkiewicz foram generalizadas por Seton [1957]:

$$
\begin{aligned}
& k_{11} p_{1}+k_{12} p_{2} \ldots \ldots \ldots+k_{1 \mathrm{n}} p_{\mathrm{n}}=\rho a_{1} p_{1} \\
& k_{21} p_{1}+k_{22} p_{2} \ldots \ldots \ldots+k_{2 \mathrm{n}} p_{\mathrm{n}}=\rho a_{2} p_{2} \\
& \ldots \ldots \ldots \ldots \ldots \ldots \ldots \ldots \ldots \ldots \ldots \\
& k_{\mathrm{n} 1} p_{1}+k_{\mathrm{n} 2} p_{2} \ldots \ldots \ldots+k_{\mathrm{nn}} p_{\mathrm{n}}=\rho a_{\mathrm{n}} p_{\mathrm{n}}
\end{aligned}
$$

Nestas equações, os $k_{\mathrm{ij}}$ representam os insumos do setor $j$ que entram na produção da mercadoria do setor $i$, medidos em termos de valor-trabalho; os $a_{\mathrm{i}}$ são os valores das mercadorias produzidas em cada setor; os $p_{\mathrm{i}}$ são os preços das mercadorias produzidas em cada setor, por unidade de valor-trabalho; $\rho$ é chamado por Seton de "razão de custo" (o total dos insumos dividido pelo valor das mercadorias), e corresponde a $\frac{1}{1+r}$, onde $r$ é a taxa média de lucro, medida em preços de produção. São supostos reprodução simples, ausência de custos fixos, e tempo de rotação unitário para os capitais de todos os setores. Após alguma manipulação algébrica, estas equações são resolvidas com a ajuda dos teoremas de Perron-Frobenius para matrizes quadradas não negativas [Seton 1957, p. 151]. To- 
dos os resultados de Bortkiewicz — impossibilidade de ter ao mesmo tempo (exceto em casos especiais) $\Sigma M=\Sigma P$ e $\Sigma m=\Sigma l$; corolário de Bortkiewicz — são confirmados.

As equações de Bortkiewicz e Seton, à primeira vista, partem dos valores para chegar aos preços de produção. Pareceria assim dar uma certa razão à teoria de Marx, apesar de as duas identidades não poderem se verificar ao mesmo tempo. No entanto, um exame mais de perto mostra que a aparência de partir dos valores é enganosa. Os "preços por unidade de valor-trabalho" de Seton, equivalentes aos $x, y$ e $z$ de Bortkiewicz, que multiplicam quantidades em valores para chegar a quantidades em preços de produção, têm na verdade a forma $P_{i} / M_{i}$, de preço de determinada mercadoria dividido por seu valor. A multiplicação dos valores por coeficientes da forma $P_{i} / M_{i}$ significa justamente eliminar os valores das equações, e determinar os preços diretamente a partir de quantidades físicas. Foi com base nisto que Samuelson formulou seu famoso "teorema da borracha (ou do apagador ${ }^{23}$ )":

Transformar de valores para preços pode ser logicamente descrito como o seguinte procedimento: 1) escreva as relações de valor; tome uma borracha e apague-as; 2) finalmente escreva as relações de preço - completando portanto o chamado processo de transformação [Samuelson 1970, pp. 423-425].

O abstract do artigo diz:

O bem conhecido procedimento da transformação, para transformar valores marxianos em preços competitivos, é mostrado como tendo logicamente a forma: 'qualquer coisa' é igual a 'qualquer outra coisa' multiplicada por 'qualquer coisa' dividida por 'qualquer outra coisa' [Samuelson 1970, p. 423] $]^{24}$.

As críticas à abordagem de Marx formuladas a partir de Bortkiewicz foram depois reforçadas por autores que se basearam no trabalho de Sraffa, como Steedman [1977]. Por esta razão, é possível falar de uma abordagem bortkiewicziana-sraffiana da questão da transformação. Nesta abordagem, já levando em conta a possibilidade de dispensar os valores na determinação dos preços de produção, as equações da "transformação" podem ser escritas, de modo mais moderno, em notação matricial, como fizeram por exemplo Morishima e Catephores [1980, pp. 171-2].

\footnotetext{
${ }^{23}$ Samuelson usa a palavra "eraser".

${ }^{24}$ Samuelson ficou tão satisfeito com sua própria piada que a repetiu no seu artigo de 1971.
} 
Inicialmente, dividimos a economia em três grupos de setores: o grupo I inclui os setores que produzem bens de capital, o II os que produzem bens de salário e o III os que produzem bens de luxo; sejam $A_{\mathrm{I}}, A_{\mathrm{II}}$ e $A_{\mathrm{III}}$ as matrizes de coeficientes de capital para os setores dos grupos I, II e III, respectivamente; sejam $L_{\mathrm{I}}, L_{\text {II }}$ e $L_{\text {III }}$ os vetores-linha de coeficientes de insumo de trabalho para os grupos; $D_{\text {II }}$ o vetor-coluna de consumo de subsistência por homens-hora; $\Lambda_{\mathrm{I}}, \Lambda_{\mathrm{II}}$ e $\Lambda_{\mathrm{III}}$ os vetores-linha dos valores dos três grupos; $p_{\mathrm{I}}$, $p_{\text {II }}$ e $p_{\text {III }}$ os vetores-linha de preços de produção para os grupos; $\pi$ é a taxa média de lucro.

$$
\begin{aligned}
& \text { Fazemos: } A=\left(\begin{array}{ccc}
A_{\mathrm{I}} & A_{\mathrm{II}} & A_{\mathrm{III}} \\
0 & 0 & 0 \\
0 & 0 & 0
\end{array}\right) ; D=\left(\begin{array}{c}
0 \\
D_{\mathrm{II}} \\
0
\end{array}\right) ; L=\left(L_{\mathrm{I}}, L_{\mathrm{II}}, L_{\mathrm{III}}\right) ; \\
& \Lambda=\left(\Lambda_{\mathrm{I}}, \Lambda_{\mathrm{II}}, \Lambda_{\mathrm{III}}\right) ; p=\left(p_{\mathrm{I}}, p_{\mathrm{II}}, p_{\mathrm{III}}\right)
\end{aligned}
$$

As equações dos valores são: $\Lambda A+L=\Lambda$

As equações dos preços de produção são: $(1+\pi) p(A+D L)=p$

O que interessa ressaltar aqui é que, com sua "solução" para o problema, Bortkiewicz e seguidores romperam claramente com a lógica de Marx. Isto é, a transformação em um sistema de equações simultâneas, e em que são separados o "sistema dos valores" e o "sistema dos preços de produção", não é uma redistribuição de um valor já dado na produção. Para que isto possa acontecer, é necessário que os preços de custo não sejam alterados, e que seja redistribuída, numa seqüência temporal, uma parte do valor já dado - isto é, que se redistribua a mais-valia. Exatamente como Marx fez, e é isto exatamente o que foi criticado desde Bortkiewicz ${ }^{25}$.

Aliás, Bortkiewicz adota a concepção do valor como sendo fundamentalmente uma relação de troca ${ }^{26}$; neste caso, não faz mesmo sentido falar em redistribuí-lo. A crítica bortkiewicziana, portanto, é uma rejeição da idéia de que faça sentido transformar valores em preços de produção redistribuindo um valor já dado através de preços que se desviam dos valores com um viés sistemático.

\footnotetext{
${ }^{25}$ Na verdade, desde antes de Bortkiewicz, como é comentado por exemplo em Ramos e Rodriguez [1996].

${ }^{26} \mathrm{O}$ que lhe dá uma grande proximidade com a concepção da economia neoclássica, em particular com sua versão walrasiana, como vimos.
} 
As características do algoritmo de Marx, resumidas nas equações de 1 a 6 apresentadas acima, criticadas e modificadas por Bortkiewicz e seus seguidores, decorrem diretamente da concepção da transformação como redistribuição de mais-valia. Em primeiro lugar, se a taxa média de lucro é calculada em valores, e desta maneira encontrada antes dos preços de produção, é porque, por um lado, a mais-valia global é definida antes dos preços de produção, no processo de produção; e porque o capital adiantado nos diversos setores $\left(C_{i}=a_{i}+v_{i}\right)$ é pressuposto, não muda na transformação. Se a mais-valia global não está dada, se os capitais adiantados não são dados previamente, e admitimos que são alterados na transformação, não há como falar em redistribuição de mais-valia. E como tratar a transformação como redistribuição de uma mais-valia determinada previamente é justamente o que garante que a soma dos valores iguale a soma dos preços de produção, e a soma das mais-valias produzidas em cada setor iguale a soma dos lucros apropriados, o abandono desta concepção terá de levar também à negação destas identidades.

Falar em redistribuição de mais-valia implica, naturalmente, considerar o valor (e conseqüentemente também a mais-valia, o capital constante, o capital variável, o preço de produção e o lucro) como formados por uma substância, o trabalho abstrato, e não como simples relação de troca. Como seria possível redistribuir relações de troca? Qual sentido poderia ter modificar relações de troca e conservar suas magnitudes globais?

De Marx para aqueles que o estariam corrigindo, o sentido da transformação perdese completamente. Para Bortkiewicz e os demais, o problema não é o de redistribuir uma massa de mais-valia (de mais-trabalho) já dada, é o de encontrar preços que, aplicados simultaneamente aos insumos e aos produtos, igualem as taxas de lucro - concebidos preços e taxas de lucro como simples relações de troca entre mercadorias ou agregados de mercadorias. Esta formulação, como se vê, já exclui os valores, ou seja, afasta-os "com o rigor necessário" dos preços de produção. Além disso, o capital adiantado "transformado", concebido como soma dos preços de produção dos insumos depois da transformação, modifica-se em relação ao capital adiantado de antes da transformação, concebido como soma dos valores dos insumos. Não há, portanto, nenhuma relação necessária ou lógica entre valores e preços de produção. Os valores só podem ser então, na melhor das hipóteses, uma redundância, como é salientado por vários dos críticos de Marx. 
Bortkiewicz parte de uma situação de reprodução simples ${ }^{27}$, com trocas das mercadorias segundo seus valores. Em seguida, abandona estes resultados. Parte do mesmo esquema de reprodução simples, mas agora adota uma regra de troca distinta: as taxas de lucro devem igualar-se. É evidente que não há redistribuição de uma mais-valia já definida — o que há é um cálculo inteiramente novo, distinto. É por isso que Samuelson pôde mostrar que dos valores não fica nada; ficam apenas as quantidades físicas. Ele tem plena razão ao afirmar que, com este procedimento, não há transformação:

Talvez eu deva explicar no começo por que as palavras 'o chamado problema da transformação’ aparecem no título ${ }^{28}$. Como o presente exame mostra, descreveriam melhor a questão as palavras 'o problema de comparar e contrastar as mutuamente excludentes alternativas de 'valores' e 'preços' [Samuelson 1971, p. 277].

Nos termos em que o problema da transformação foi colocado desde Bortkiewicz, Samuelson está certo.

$\mathrm{Na}$ abordagem bortkiewicziana, a transformação dos valores em preços de produção, conservando o sentido fundamental do valor, não é apenas impossível: rigorosamente, não faz sentido. Se valor é uma relação de troca entre as mercadorias, e se preço de produção é outra relação de troca, o que se pode fazer é substituir um pelo outro, jamais transformar o primeiro no segundo conservando suas características fundamentais, como pretendeu Marx. Como satisfazer simultaneamente duas lógicas de troca distintas? Em qual sentido relevante uma relação de troca segundo quantidades de trabalho pode ser incorporada em uma relação de troca segundo equivalência das taxas de lucro?

\section{3 - A ABORDAGEM DO SISTEMA ÚNICO TEMPORAL}

\subsection{1 - Visão geral}

Com a abordagem do sistema único temporal, alguns aspectos fundamentais da concepção de Marx podem ser recuperados: a recusa em entender o valor apenas como

\footnotetext{
${ }^{27}$ Como mencionamos em nota anterior, poderia partir também de um esquema de reprodução ampliada, como fazem alguns de seus continuadores.

${ }^{28}$ O título do artigo é: "Understanding the Marxian Notion of Exploitation: A Summary of the So-Called Transformation Problem Between Marxian Values and Competitive Prices”.
} 
uma relação de troca; a sua definição como uma substância social, o trabalho abstrato, que se objetiva nas mercadorias, se corporifica e se socializa necessariamente no dinheiro, sua forma por excelência, que é redistribuível através de desvios dos preços, que ganha autonomia no processo de circulação e valorização dos capitais. É no interior deste processo que se formam os valores e os preços de produção das mercadorias. Tudo isto permite entender a transformação como um processo real, e não como simples operação lógico-teórica $^{29}$

A partir daí, duas características básicas do método de Marx são enfatizadas: a recusa de promover uma cisão entre um sistema dos preços de produção e um sistema dos valores, e conseqüentemente a formulação da transformação dos valores em preços de produção em um único sistema de equações, em que valores e preços de produção se entrelaçam - o não dualismo; e o tratamento de todo o processo de formação dos valores e dos preços de produção numa seqüência temporal — o sequencialismo, ou o caráter temporal.

O ponto-chave em que esta reconceptualização incide sobre o problema da transformação é o da definição do valor do capital constante e do capital variável, feita de um modo muito diferente do normalmente aceito.

O capital constante não é concebido como constituído pelos meios de produção comprados pelos capitalistas, mas como o dinheiro (ou seja, o capital) com que os capitalistas compram esses meios de produção. Conseqüentemente, o valor do capital constante não é dado pelos valores dos meios de produção que ele compra, mas pelo seu valor em dinheiro, que corresponde aos preços de produção dos meios de produção comprados. Assim, o valor dos meios de produção e o valor do capital constante são diferentes.

Da mesma maneira, o capital variável não é concebido como constituído pelos meios de consumo que os trabalhadores adquirem com o salário que recebem, mas como $o$ dinheiro (o capital) com que os capitalistas contratam esses trabalhadores. Conseqüentemente, o valor do capital variável não é dado pelos valores dos meios de consumo adquiridos pelos trabalhadores, mas pelo montante de dinheiro que os capitalistas lhes pagam

\footnotetext{
29 Não há pleno acordo entre os autores que defendem esta abordagem com relação a todas as suas características. O que apresentamos aqui é uma versão desta abordagem, com diversos aspectos não encontrados nos autores citados na seção 4.1.
} 
como salário. Assim, o valor dos meios de consumo dos trabalhadores é diferente do valor do capital variável; este último é dado pelo preço de produção dos meios de consumo dos trabalhadores, e não pelos seus valores ${ }^{30}$.

Com estas conceituações, a definição do valor de uma mercadoria como a soma dos valores do capital constante consumido e do capital variável com a mais-valia ganha um novo sentido, como soma de duas quantidades de valor expressas em dinheiro com a maisvalia. $\mathrm{Ou}$, alternativamente, e de forma mais rigorosa, podemos considerar o valor de uma mercadoria como a soma de uma quantidade de valor expresso em dinheiro - o capital constante consumido - com o valor novo $-v+m$, o trabalho vivo. A mais-valia é, muito naturalmente, a diferença entre o valor da mercadoria produzida - expresso em dinheiro - e seu preço de custo, sendo este a soma de duas quantidades de dinheiro, o capital constante consumido e o capital variável. Logo, a mais-valia também se expressa em dinheiro. A taxa de lucro é o quociente entre duas quantidades de valor, ambas expressas em dinheiro, a mais-valia e o valor do capital adiantado.

Uma vez aceitas estas definições, e lembrando que todo o processo só pode ser entendido numa seqüência temporal, fica claro que o argumento sempre repetido para provar a inconsistência lógica do "algoritmo da transformação" usado por Marx — o de que ele não completou a transformação — é destituído de fundamento. Marx não carecia de transformar os valores do capital constante e do capital variável em preços de produção, porque estes valores são dados em dinheiro, e porque os valores dos meios de produção adquiridos pelos capitalistas, e dos meios de consumo adquiridos pelos trabalhadores, já haviam sido transformados em preços de produção em um momento anterior.

Permanece, naturalmente, a necessidade de "completar o exemplo" da transformação apresentado por Marx no Capítulo IX do Livro III de O Capital. Como ele próprio observou em uma das passagens deste capítulo freqüentemente citadas como confissão de

\footnotetext{
${ }^{30}$ Esta interpretação dos conceitos de capital constante e de capital variável é coerente com as passagens do Capítulo IX (e do Capítulo XII) do Livro III d'O Capital que geralmente são entendidas como reconhecimentos por Marx da incorreção do procedimento que utilizou para transformar valores em preços de produção. Observemos que Marx não disse nem uma vez que reconhecia que seu procedimento era incorreto isto é apenas uma interpretação defendida pelos críticos da transformação marxiana. A este respeito, o artigo recente de Fred Moseley [Moseley 2001-2] é esclarecedor.
} 
erro, ele não examinou mais de perto todas as suas características. Mas é perfeitamente possível completar o algoritmo usado por ele mantendo sua conceptualização da relação entre os valores e os preços de produção, como veremos.

\subsection{2 - Os níveis de abstração e a transformação}

Uma das maneiras de justificar o sistema único temporal e de mostrar a inconsistência da abordagem bortkiewicziana-sraffiana da transformação com a concepção de Marx é partir da concepção marxiana dos níveis de abstração, e da relação entre eles.

Marx introduz o conceito de preço de produção no Livro III de $O$ Capital. Neste Livro o nível de abstração é menor do que nos anteriores; o tema da redução do nível de abstração foi desenvolvido na Introdução à Crítica da Economia Política, como vimos no Capítulo 2. A exposição científica parte de maiores níveis de abstração, e caminha para níveis mais reduzidos.

Em $O$ Capital, este método assume um conteúdo mais específico: sobretudo o da passagem do nível do capital em geral ao dos muitos capitais ${ }^{31}$. No capital em geral, os capitais são considerados simplesmente enquanto tais, naquilo que têm em comum; nos muitos capitais, eles são analisados na sua individualidade e nas suas diferenças. O capital em geral pode também ser entendido como o capital social global, tomado indiferenciadamente como um único capital; no Livro I e no Livro II, Marx contrapõe basicamente o capital global e a força de trabalho também global, analisando a produção em geral, e depois a circulação em geral, e não as condições de produção ou de circulação de mercadorias específicas ${ }^{32}$. O nível dos muitos capitais é o das "formas concretas que surgem do

\footnotetext{
${ }^{31} \mathrm{O}$ que também vimos no Capítulo 2.

${ }^{32}$ Como observa Fred Moseley [Moseley 1993b]. Mas a interpretação defendida por este autor, de que o capital em geral só pode ser o capital global é incorreta - o capital em geral é um capital qualquer, global ou individual, e Marx faz referências também a casos individuais. Assim, quando menciona, no Capítulo III do Livro I, a possibilidade de incongruências entre valor e preço, está se referindo obviamente a uma mercadoria específica; o mesmo acontece quando, no Capítulo IV do mesmo livro, fala da possibilidade de venda acima ou abaixo do valor. Além disso, o "princípio metodológico" de que o valor e a mais-valia se determinam no global, uma das bases da argumentação de Moseley, pode ser substituído com vantagem pelo seguinte enunciado, muito mais simples: valor e mais-valia podem ser transferidos na circulação, mas só podem ser criados na produção.
} 
movimento do capital considerado como um todo" - incluindo portanto produção e circulação - e inclui especialmente as conseqüências da concorrência entre os capitais.

Como fica claro pelo texto da Introdução, para Marx, reduzir o nível de abstração, aproximar-se do concreto, significa incluir, sintetizar novas determinações, acrescentandoas ao modelo mais abstrato; portanto, inter-relacionar as determinações já existentes com outras, e não substituí-las (que é o que se faz na abordagem bortkiewicziana, em que se abandona a "troca segundo os valores" em favor da "troca segundo os preços de produção”). Até o início do Livro III de O Capital movimentamo-nos em um espaço teórico em que já há valores e preços (que, inicialmente, são simplesmente a forma preço, os valores expressos em dinheiro) ${ }^{33}$, mas não preços de produção; a partir daí, passamos a um espaço teórico que inclui também os preços de produção. Existe portanto um sistema dos valores sem preços de produção, como quer a abordagem bortkiewicziana, mas não existe um sistema dos preços de produção, e menos ainda um sistema dos preços, sem valores, como esta abordagem pretende igualmente.

A passagem do sistema dos valores (o nível do capital em geral) ao sistema dos valores e dos preços de produção (o nível dos muitos capitais) modifica, naturalmente, a "regra de troca". As determinações que se acrescentam implicam uma regra de troca mais complexa em que, além da simples troca de mercadorias segundo seus valores, realiza-se uma redistribuição do valor, isto é, de parte da mais-valia, de modo a igualar (tendencialmente) as taxas de lucro. Ou seja: a troca segundo os preços de produção envolve mais determinações do que a troca segundo os valores; é troca + transferência de valor, troca desigual, e além disso com uma desigualdade muito precisa. De fato, a novidade é justamente o caráter preciso desta desigualdade. A possibilidade de troca desigual, de desvios dos preços em relação aos valores, já está presente (e é enfatizada) no Livro I; o que é acrescentado no Livro III é a definição de um viés para estes desvios: com a tendência a que as taxas de lucro se igualem, os preços (de mercado) tendem a variar em torno dos

\footnotetext{
${ }^{33} \mathrm{Na}$ literatura padrão sobre o problema da transformação, costuma-se dizer que no Livro I d'O Capital Marx trata de valores, e que no Livro III passa aos preços. Isto é um erro grosseiro; que este erro seja relativamente comum mostra bem a falta de rigor, de seriedade e de respeito com que vários comentadores de Marx tratam sua teoria. O conceito de preço, incluindo a menção a que os preços podem desviar-se dos valores, aparece desde a primeira seção do Livro I, como vimos no Capítulo 1, subseção 1.3.1.
} 
preços de produção. Fica claro, portanto, que a modificação da regra de troca não é uma substituição (no sentido de abandono de uma por outra); é uma inclusão de mais determinações, a adoção de uma "regra de troca" conceitualmente mais complexa.

Há, portanto, uma mudança na regra de troca, de uma mais simples para outra mais complexa. Mas não é esta transformação da regra de troca, decorrente da redução do nível de abstração, que constitui a transformação dos valores em preços de produção. Segundo este entendimento, a transformação seria uma operação lógico-teórica. Ao contrário, a transformação não é a passagem de um nível de abstração ao outro, é um movimento no mesmo nível de abstração (o dos muitos capitais). Como explicou Marx na Seção II do Livro III de O Capital, é um movimento em que, após a produção, o valor é redistribuído de modo a que a venda das mercadorias possa se fazer igualando as taxas de lucro. Um movimento a partir do qual os capitalistas não se apropriam da mais-valia produzida pelos "seus" próprios trabalhadores, mas da fração da mais-valia que corresponde ao volume (e ao tempo de rotação) de seu capital. Transformar os valores em preços de produção é uma forma (tendencial) de redistribuir o valor, que ocorre normalmente na economia capitalista.

É fundamental compreender que o método de Marx de ir do abstrato ao concreto não é o mesmo que começar introduzindo muitas hipóteses simplificadoras que depois são progressivamente relaxadas (o método das "aproximações sucessivas" ${ }^{34}$ ), como se costuma entender esta questão na abordagem bortkiewicziana. Segundo esta concepção, o nível mais abstrato seria apenas uma construção mental, não existiria na realidade; seria apenas uma aproximação maior ou menor do real, que cresce à medida que vamos suprimindo hipóteses simplificadoras. De acordo com o método de Marx, ao contrário, o que construímos no processo de conhecimento como nível abstrato são aspectos da realidade, são conceitos que têm uma correspondência real — é a realidade tomada de modo mais simplificado, isto é, considerando apenas suas determinações mais fundamentais. O nível mais concreto inclui estes aspectos, não os exclui como no método das "aproximações sucessivas". Desta forma fica claro que a idéia de um "sistema de preços de produção" rigorosamente separado dos valores, isto é, o que chamamos de dualismo metodológico — base da abordagem bortkiewicziana - é um nonsense para o método de Marx.

\footnotetext{
34 Já mencionado, e criticado, no Capítulo 2.
} 
A não aplicação do método das aproximações sucessivas, por outro lado, não significa que Marx não use jamais hipóteses simplificadoras. Ele as usa, para poder "tratar os problemas na sua pureza". Este é o sentido da hipótese de venda das mercadorias pelos seus valores no Livro I. Outros exemplos de hipóteses simplificadoras são a de taxas de mais-valia iguais (e em geral iguais a 100\%) que Marx usa em todo O Capital, e a do valor do dinheiro constante, na questão da transformação. O decisivo é que estas hipóteses simplificadoras são de fato apenas simplificações, isto é, não interferem nos termos fundamentais dos problemas tratados.

Assim, na transformação realizada no Livro III de $O$ Capital, valores e preços de produção convivem em um mesmo nível de abstração, em um mesmo espaço teórico. É aí, no sistema dos valores e dos preços de produção, que a questão da transformação deve ser colocada, como um processo real de redistribuição, de transferência de valor de um capital para outro. E só desta maneira pode ser colocada como um processo real.

Outro ponto decisivo é que, se transformação dos valores em preços de produção não é, e não pode ser, a passagem do sistema dos valores ao sistema dos preços, mas $\operatorname{sim}$ a passagem dos valores a preços de produção dentro do mesmo "sistema", é necessário então introduzir o tempo. Se valores e preços de produção não diferem como elementos de sistemas distintos, só podem se distinguir como elementos diversos numa seqüência temporal. A passagem dos valores aos preços de produção deve ser entendida, portanto, como uma sucessão temporal real, como um deslocamento num tempo lógico e cronológico.

Assim, devemos recusar a concepção (bortkiewicziana) da transformação como uma passagem (puramente teórica) de um "sistema" a outro, e adotar a concepção em que há um movimento temporal real no interior de um mesmo "sistema".

Por outro lado, se o valor convive com o preço de produção no nível mais reduzido de abstração, o dos muitos capitais, só pode ser um conceito de valor mais complexo. Ao passar do nível mais abstrato para o nível mais concreto, uma categoria se relaciona com outras determinações, é inserida em um todo mais rico. Por isto tem de mudar. Assim, de um nível em que não há preços de produção, embora haja preços, o valor passa para outro em que há também preços de produção. Insere-se, portanto, em uma inter-relação mais densa de categorias; já se apresenta de modo mais concreto, sintetizando mais determinações. Este desenvolvimento do conceito de valor significa, entre outras coisas, que ele passa a sofrer influências da circulação; embora a circulação não possa criar valor, pode 
interferir na sua determinação por meio de transferências de valor relativas a mercadorias que entram no processo de produção ${ }^{35}$.

Assim, o valor de que se trata na transformação dos valores em preços de produção não é o valor tal como definido no nível do capital em geral; é o valor redefinido no nível dos muitos capitais, inserido em uma síntese mais complexa de determinações. É o valor que está no mesmo "sistema", no mesmo espaço teórico que os preços de produção.

É esta compreensão que dá sentido à afirmação de Marx de que o valor global e a mais-valia global se conservam na transformação, isto é, de que as duas identidades (soma dos valores $=$ soma dos preços de produção, e soma das mais-valias = soma dos lucros) se realizam. Se se tratasse do mesmo valor do nível mais abstrato, ele estaria num espaço teórico distinto do dos preços de produção, e qualquer comparação entre eles seria pelo menos duvidosa. É porque integram o mesmo espaço teórico que valores e preços de produção são comensuráveis ${ }^{36}$, ou seja, que é possível compará-los quantitativamente, igualar sua soma, etc.

O tratamento mais explícito da redução do nível de abstração como inclusão de determinações, na literatura sobre a teoria marxista do valor e dos preços de produção, é o de Isaak Rubin, no seu livro clássico. Uma de suas bases é a afirmação de que as categorias da $1^{\text {a }}$ Seção do Livro I não se referem a uma economia pré-capitalista, mas sim a aspectos

\footnotetext{
35 Wolff, Roberts e Callari tratam da inter-relação das categorias por meio do conceito althusseriano de sobredeterminação: "Este conceito muito incompreendido implica, naturalmente, mútua e recíproca determinação, mas mais está envolvido além de simplesmente as direções da causalidade. A sobredeterminação implica adicionalmente relações de constitutividade, o poder de cada aspecto da sociedade não apenas de afetar outros aspectos, mas também de efetivá-los, constituí-los, participar na determinação da natureza, bem como de mudanças, de todos os outros aspectos" [Wolff, Roberts e Callari 1982, p. 565].

${ }^{36}$ É importante ter em conta que o valor de que Marx fala na transformação é o valor expresso em dinheiro, como preço - é portanto o que ele chama de preço-valor (ver, a este respeito, a subseção 5.3.3 do Capítulo 5). Não é possível, portanto, questionar a comensurabilidade de valores e preços por terem dimensões distintas, tempo de trabalho e unidades monetárias.
}

Resta a questão dos espaços teóricos distintos que muitos acreditam existir. Esta compreensão costuma implicar o questionamento da comensurabilidade de valores e preços de produção; isto leva diversos autores a discussões bastante confusas. Este questionamento seria bastante defensável se valores e preços de produção pertencessem de fato a espaços teóricos distintos. 
de toda economia mercantil, que só se desenvolvem plenamente na própria economia capitalista. Valor, trabalho abstrato, dinheiro, portanto, têm existência real, antes de mais nada, na economia capitalista ${ }^{37}$. Embora esta compreensão atravesse todo o livro, explicitase de modo mais claro no fim do capítulo sobre valor e preços de produção, quando Rubin critica a "interpretação histórica do valor-trabalho" [Rubin 1980, Capítulo 18: 272-276 e 1974: 310-314].

Um dos argumentos principais de Rubin para mostrar a coerência da transformação dos valores em preços de produção é o fato de que a "teoria do valor" se baseia numa cadeia de quatro determinações básicas (produtividade do trabalho - trabalho abstrato valor - distribuição do trabalho social), enquanto a "teoria dos preços de produção" se baseia numa cadeia de seis determinações (produtividade do trabalho - trabalho abstrato — valor - preço de produção — distribuição do capital — distribuição do trabalho social) [Rubin 1980, Capítulo 18: $241^{38}$ e 268; e 1974: 278 e 306], que inclui as quatro determinações anteriores. Ele critica nitidamente o tratamento da transformação com base na contraposição de dois "sistemas", embora não use estes termos:

Assim, a teoria do valor-trabalho e a teoria do preço de produção não são teorias de dois tipos diferentes de economia, mas teorias de uma mesma economia capitalista considerada sob dois níveis diferentes de abstração [Rubin 1980, Capítulo 18, p. 272 e 1974, pp. 309$10]^{39}$.

Rubin, contudo, não trata especificamente do "problema da transformação" tal como definido por Bortkiewicz, com sua ligação com os “esquemas de reprodução" e seus

\footnotetext{
${ }^{37}$ Como vimos no Capítulo 2, subseção 2.2.2.

${ }^{38} \mathrm{Na}$ edição brasileira, nesta página é omitido o valor da cadeia de determinações dos preços de produção; este erro não aparece na edição em espanhol, nem na página 268 da edição brasileira.

${ }^{39}$ Esta passagem continua: “A teoria do valor-trabalho é uma teoria da economia mercantil simples, não no sentido de explicar o tipo de economia que precedeu à economia capitalista, mas no sentido de descrever apenas um aspecto da economia capitalista, ou seja, relações de produção entre produtores mercantis que são características para toda economia mercantil [Rubin 1980, p. 272 e 1974, pp. 309-10]. Como já foi observado no Capítulo II, é preferível não tratar a teoria do valor como "uma teoria da economia mercantil simples", e sim diretamente como a formulação abstrata de aspectos característicos de toda economia mercantil. Mas de qualquer maneira, o fundamental é a afirmação de que não se trata da teoria de um outro tipo de economia, contraposto à economia capitalista.
} 
sistemas de equações; menciona de passagem a crítica de Tugan-Baranowsky [Rubin 1980, p. 254 e 1974, p. 291], em que Bortkiewicz se baseou, referindo-se à questão da mudança do valor do capital constante e do capital variável na transformação, mas não desenvolve o assunto. Não menciona o tempo. A partir do seu capítulo, portanto, não fica claro como o correto tratamento da questão dos níveis de abstração evita o problema levantado por Bortkiewicz. Foi portanto possível que, nas últimas décadas, autores que valorizam o trabalho de Rubin, e se apóiam nele em várias questões, tenham aceitado, no todo ou em parte, a formulação bortkiewicziana do problema da transformação, com seus "dois sistemas", suas regras de troca rigorosamente separadas e com suas decorrências, não percebendo que isto contradiz expressamente sua metodologia ${ }^{40}$.

\subsection{3 - Valores do capital constante, do capital variável, mais-valia e}

\section{taxa de lucro}

O objetivo desta seção é argumentar em favor das reconceptualizações decorrentes da abordagem do sistema único temporal que têm decorrências mais claras para a transformação dos valores em preços de produção.

O valor das mercadorias, como se sabe, é determinado pelo trabalho socialmente necessário à sua produção, direta e indiretamente. Inclui portanto o valor transferido pelos meios de produção consumidos. Mas como se dá essa inclusão, essa passagem do valor de algumas mercadorias (os meios de produção) para outras (as mercadorias produzidas)? Embora esta questão não seja em geral objeto de debate, não é de nenhuma maneira óbvia. É claro que, por exemplo, sendo a objetividade do valor puramente social, não faz sentido pensá-la como alguma passagem físico-místico-metafísica de "átomos de valor" dos meios de produção para os produtos.

Desde a Seção I do Livro I de $O$ Capital é mostrado esse processo de transferência do valor passa pela circulação. Se nos situamos no nível de abstração desta seção, podemos dizer que um produtor de mercadorias compra os meios de produção com determinada soma de dinheiro, que expressa o seu valor, na média. O produtor, que detinha uma fração do trabalho social na forma de dinheiro, recebe através da troca esta mesma fração, na

\footnotetext{
${ }^{40}$ Um exemplo conspícuo é o livro de Pierre Salama e Tran Hai Hac [1992]. Mas há inúmeros outros.
} 
forma de meios de produção. À medida que estes vão sendo consumidos, uma parte do trabalho social objetivada neles vai sendo transferida para as mercadorias produzidas. Não há metafísica: de fato, usar os meios de produção é usar essa parcela do trabalho social; produzir é gastar tanto o trabalho diretamente exercido quanto o trabalho anterior, necessário à produção dos meios de produção, e é perfeitamente natural somar estas duas parcelas para chegar a um quantum de trabalho social — o conteúdo do valor das mercadorias.

Se passamos para o nível de abstração do capital em geral, que é o nível em que esta questão é analisada a partir do Capítulo IV do Livro I, várias diferenças aparecem: o antigo produtor se desdobra em capitalista e trabalhador; o dinheiro com que o capitalista (agora separado do trabalhador) compra os meios de produção torna-se capital constante, uma parte do seu capital; e tudo isto se insere no movimento de valorização do capital. Essas diferenças são, é claro, muito importantes; mas como mantemos a hipótese de troca segundo os valores, o processo de transferência de valor continua basicamente o mesmo: a fração do trabalho social pré-existente nos meios de produção, que é incorporada aos novos produtos, é a mesma fração representada pelo dinheiro (pelo capital constante) com que os meios de produção foram adquiridos. A passagem pela circulação continua neutra, não acrescenta nenhuma complicação importante. O valor do capital-dinheiro que se transforma em capital constante é equivalente ao valor dos elementos materiais que o compõem.

No entanto, para que possamos tratar do caso mais complexo, no nível dos muitos capitais, é preciso refletir mais cuidadosamente sobre a lógica deste processo. É o que Marx faz em um parágrafo dos Manuscritos de 1861-1863 (o segundo esboço de O Capital), quando trata do processo de trabalho como processo de valorização (portanto, em um trecho correspondente à segunda parte do Capítulo V do Livro I de O Capital):

Os valores dos meios e dos materiais de trabalho, portanto, aparecem de novo no produto como constituintes do seu valor. Este valor é pressuposto [este grifo e o anterior são de Marx - JM], já que o tempo de trabalho contido nos meios e materiais de trabalho estava expresso nos seus preços na sua forma geral, como trabalho social: são os preços pelos quais o possuidor de dinheiro comprou-os como mercadorias antes de começar o processo de trabalho. Os valores de uso em que consistiam pereceram, mas eles próprios permaneceram inalterados e continuam inalterados no novo valor de uso. A única mudança ocorrida é que aparecem como meros constituintes, fatores do seu valor, como fatores de um valor novo. Na medida em que a mercadoria é em suma valor de troca, o valor de uso particular, a determinidade material particular na qual ela existe é afinal apenas um equivalente, e 
pode portanto mudar sua encarnação por qualquer outra. Pela circulação, e antes de mais nada pela transformação em dinheiro, ela é de fato capaz de se dar a substância de qualquer outro valor de uso [Marx, Economic Manuscript of 1861-1863, vol. I, pp. 73/4] ${ }^{41}$.

Marx aqui diz que o valor dos meios de produção, que reaparece como constitutivo do valor do produto, é pressuposto, porque o tempo de trabalho contido neles se expressava nos seus preços - em sua forma geral, como trabalho social. E acrescenta que esses são os preços pelos quais o possuidor do dinheiro comprou os meios de produção. Esta indicação de que o valor dos meios de produção é pressuposto é fundamental, pois a lógica de toda a operação é a do processo de valorização: o capitalista tem determinada soma de dinheiro - seu capital — que movimenta para fazê-la crescer; essa soma de dinheiro, portanto, é dada, pressuposta.

Marx segue: os valores de uso perecem, mas eles próprios (os valores) permanecem inalterados no novo valor de uso, como fatores do novo valor. Para reforçar o fato de que os valores de uso particulares em que o valor se representava importam pouco, diz que $a$ determinidade material particular em que o valor existe é afinal apenas um equivalente, e pode portanto trocar sua encarnação por uma outra. E a conclusão: pela circulação, e antes de tudo sendo transformada em dinheiro, a mercadoria é de fato capaz de se dar a substância de qualquer outro valor de uso.

Todo este parágrafo trata da transferência do valor dos meios de produção para os produtos no nível do capital em geral; mas a explicitação da sua lógica aqui é extremamente útil para o caso dos muitos capitais. Neste caso, aparece uma complicação: os meios de produção são mercadorias vendidas por seu preço de produção; a venda pelo preço de produção, como vimos, é troca + transferência de valor na circulação. O capitalista, com uma soma de dinheiro que representa determinado valor, compra meios de produção de um valor diferente. Como definir nesse caso o valor do capital constante? Dos meios de produção? E o valor transferido pelos meios de produção para os produtos?

Quanto ao valor do capital constante, não pode haver dúvidas: capital constante é uma subdivisão do capital adiantado, uma soma de dinheiro; e dinheiro é concretização material geral do trabalho humano abstrato, é a representação geral do valor. Assim, é

\footnotetext{
${ }^{41}$ Fred Moseley [1993b, p. 170] citou parcialmente esta passagem, chamando portanto a atenção para ela.
} 
essa soma de dinheiro que define o valor do capital constante. E quanto ao valor dos meios de produção? No sentido do tempo de trabalho socialmente necessário à sua produção, não há dúvida de que o valor dos meios de produção é diferente do valor do dinheiro com que são comprados, isto é, do capital constante, pois são vendidos por seus preços de produção. Mas Marx diz também que o tempo de trabalho contido neles se expressa nos seus preços - em sua forma geral, como trabalho social, e neste sentido é pressuposto. Ou seja, a partir do momento em que os meios de produção são vendidos ao capitalista, estabelecem sua equivalência com o capital constante a partir de seus preços (de produção); e esses preços, que são a forma geral do trabalho social, passam a representar seu valor. $O$ valor com que os meios de produção integram o capital produtivo é o preço por que foram comprados no caso, o preço de produção.

A lógica disto é bem exposta na seqüência do parágrafo de Marx: os meios de produção contam no processo de valorização apenas como o equivalente de um valor; sua determinidade material particular não importa, ela pode mudar de uma "encarnação" do mesmo valor para outra. Importa a equivalência que seu valor estabelece com a forma geral do trabalho social (o dinheiro): ou seja, importa seu preço (no caso, preço de produção). Depois da compra dos meios de produção, continuar a contar seu valor de acordo com o tempo de trabalho socialmente necessário à sua produção seria desconsiderar os efeitos da troca (que é uma troca mais complexa, troca + transferência de valor na circulação). Em resumo: se os capitalistas pagam pelos meios de produção segundo seu preço de produção, é a partir deles que o valor transferido pelo capital constante às mercadorias produzidas deve ser calculado. Porque é assim que os meios de produção ingressam na esfera produtiva: trocando-se pelo dinheiro do capitalista, representando a fração do trabalho social correspondente a esta quantidade de dinheiro e ao seu preço de produção ${ }^{42}$.

\footnotetext{
${ }^{42}$ McGlone e Kliman explicam esta questão da seguinte maneira: "Como a incorporação de trabalho abstrato, alienado é um processo social peculiar, e não como tal um requerimento tecnológico, o trabalho abstrato incorporado em uma mercadoria não precisa igualar a quantidade de trabalho (concreto) necessário para reproduzi-la. Embora a troca não altere o quantum de valor em existência, ela o redistribui. Como o trabalho abstrato é redistribuído pela troca, algumas mercadorias incorporam mais trabalho abstrato do que teriam de outra maneira, algumas menos. À base desta noção de incorporação de trabalho, podemos compreender como o capital adiantado para a produção não deixa de ser uma soma de valor apenas porque difere do valor dos seus elementos materiais (meios de produção e de subsistência)" [McGlone e Kliman 1996, p. 32].
} 
Podemos colocar esta questão de outra maneira: o capital é um movimento do valor, o qual realiza várias metamorfoses, assume diversos envoltórios materiais (dinheiro, meios de produção e força de trabalho, mercadorias produzidas que devem ser vendidas). Considerar que o valor transferido dos meios de produção é o valor dos seus elementos materiais significaria pensar o capital como um movimento de valores de uso: os elementos físicos do capital constante (com seus "átomos de trabalho abstrato incorporados") transformar-seiam em capital produtivo. Isto é claramente absurdo; não faz sentido dizer que são as próprias mercadorias produzidas que, ao serem vendidas, transformam-se "fisicamente" em meios de produção.

Basta analisar toda esta seqüência concretamente, considerando a transformação dos valores em preços de produção como um processo temporal e real, para vermos que o modo de tratar a questão que defendemos é o único possível. O capitalista paga os elementos materiais que compra de acordo com seus preços de produção; para ele, o valor dos seus meios de produção corresponde ao valor do dinheiro que pagou por eles - corresponde portanto aos preços de produção dos meios de produção. É esta a base que usa para calcular seus custos. Como poderia ser de outra maneira? E se o cálculo não for feito assim, esta parte do capital perderá ou ganhará valor ao se transformar em meios de produção, para a partir daí passar seu valor para as mercadorias produzidas — não será portanto um valor pressuposto, e não será capital constante.

Definindo o valor do capital constante a partir do valor do dinheiro com que são comprados, estamos portanto seguindo o curso lógico das ações dos capitalistas na vida real. Buscamos refletir (com as categorias valor e preço de produção) processos reais, e não processos imaginários. Quando reunimos valores e preços em um mesmo nível de abstração, e os tomamos como conceitos que correspondem a aspectos da realidade, fica inteiramente absurdo dizer que mercadorias que se vendem por seu preço de produção transferem valor segundo seus valores, valores esses pelo quais elas não são compradas; isto seria criar um conceito de valor metafísico, no sentido próprio da palavra.

Ninguém faz isto, é claro: Bortkiewicz e seus seguidores, que separam o sistema dos valores do sistema dos preços de produção, dizem que os meios de produção transferem valor aos produtos segundo seus valores apenas no sistema dos valores, e neste caso supõem que eles são comprados desta maneira. Assim, a única maneira lógica de dizer que os meios de produção transferem valor às mercadorias produzidas de acordo com seu valor 
é separar os valores dos preços de produção, isolando-os no sistema dos valores. É por isso que podemos dizer que, quando abandonamos o dualismo metodológico e adotamos a concepção não dualista, a única maneira de tratar o valor do capital constante é a que defendemos aqui.

Quando tratamos valores e preços de produção como integrantes de um mesmo espaço teórico, e consideramos a transformação como processo temporal real, só podemos concluir que os meios de produção transferem o valor que corresponde ao dinheiro - o capital constante - que os compra.

Este tratamento do valor do capital constante tem conseqüências na definição do valor das mercadorias produzidas. Ele é formado pela soma de duas parcelas: o valor transferido do capital constante, e o valor acrescentado pelo trabalho vivo (que Marx chama de valor novo, ou de produto-valor, Wertprodukt). O valor das mercadorias é dado portanto por: consumo de capital constante (considerado segundo o valor do dinheiro que o comprou) + valor novo.

Faz sentido definir o valor de uma mercadoria desta maneira, isto é, chamar uma grandeza formada pela soma do valor transferido pelo consumo do capital constante (calculado segundo o valor do dinheiro que o comprou, que equivale ao preço de produção dos seus elementos materiais) e pelo valor adicionado pelo trabalho vivo de valor? De acordo com as considerações feitas até aqui, sim, faz sentido. O dinheiro é um quantum de valor, representa uma quantidade de trabalho abstrato, uma fração do trabalho social. Tanto preços correspondentes aos valores quanto preços que se desviam dos valores referem-se a quantidades de trabalho abstrato objetivadas, ou seja a valores. Assim, a soma do valor do capital constante consumido, calculado segundo o dinheiro que comprou os meios de produção por seus preços de produção, com o valor novo adicionado constitui uma determinada quantidade de trabalho abstrato, ou de valor. Tudo isto não faria sentido se valor e preço de produção tivessem dimensões diferentes, representassem qualidades heterogêneas. Mas isto não acontece: o valor se expressa em dinheiro, como preço, e os preços correspondem também a quantidades de trabalho abstrato; valor e preço de produção referemse ambos a "gelatinas de trabalho abstrato", expressas em dinheiro ${ }^{43}$.

\footnotetext{
${ }^{43}$ Em O Capital III-IV, p. 252 há uma frase muito significativa: "Um preço que é qualitativamente distinto do valor é uma contradição absurda".
} 
A diferença entre valor e preço de produção diz respeito ao momento analítico em que são definidos. O valor é formado no curso do processo de produção: a uma dada quantidade de capital constante (ou seja, de dinheiro) já existente, que é consumida, que representa trabalho morto, incorpora-se uma dada quantidade de trabalho vivo; o valor está completo quando a produção termina. O preço de produção é definido no instante seguinte, em um momento analiticamente posterior, quando a mercadoria sai da produção e entra na circulação. Aí, faz-se uma redistribuição da mais-valia, que será confirmada no momento da venda. No nível de abstração dos muitos capitais, portanto, não existe venda segundo o valor da mercadoria: as mercadorias se vendem pelos seus preços de produção.

Estas definições implicam a interferência da circulação na determinação do valor de uma mercadoria, devido à transferência de valor no momento da compra dos meios de produção. Isso reflete o fato de que o nível dos muitos capitais é o do "processo do movimento do capital considerado como um todo", e não é inconsistente com a posição básica de Marx de que o valor é criado apenas na produção. A circulação interfere na determinação do valor apenas transferindo um valor já existente entre as mercadorias. As mercadorias, para Marx, são portadoras de um valor que não é intrínseco a elas; o valor é uma relação social, não uma propriedade das coisas, e nenhuma contradição aparece se as mercadorias $M$ transferem mais ou menos valor ao produto do que elas adquirem na produção ${ }^{44}$.

Esse raciocínio sobre o valor do capital constante corresponde, em grande parte, ao que é necessário para definir o valor do capital variável. Tal como o capital constante, o capital variável é uma subdivisão do capital adiantado, é uma soma de dinheiro, e essa soma de dinheiro define o seu valor. Se os capitalistas pagam pela força de trabalho segundo o preço de produção dos meios de consumo necessários aos trabalhadores, é desta forma que o valor do capital variável deve ser considerado; é desta forma que os meios de consumo estabelecem sua equivalência ao dinheiro.

No nível mais abstrato, do capital em geral, o valor da força de trabalho corresponde ao valor dos meios de consumo consumidos pelos trabalhadores. Mas isto deixa de fazer sentido quando reduzimos o nível de abstração e incluímos os preços de produção ao lado dos valores. Os trabalhadores compram seus meios de consumo de acordo com seus

\footnotetext{
${ }^{44}$ Como observa Alan Freeman [Freeman 1996a, p. 17].
} 
preços de produção, com determinada quantidade de dinheiro que recebem dos capitalistas. É claro que o valor do capital variável só pode ser o desta quantidade de dinheiro. Ao capitalista não interessa saber em que os trabalhadores gastarão seus salários, para a partir daí calcular seu valor. Pelo contrário: o capitalista parte de determinada soma de dinheiro (seu capital), como um dado, e a usa para comprar meios de produção e força de trabalho, transforma-a portanto em capital produtivo, para fazê-la crescer. Ele só pode calcular seu preço de custo, seu $c+v$, de acordo com o dinheiro que adiantou. Calcular $v-$ uma parte dos custos - a partir do valor que os meios de subsistência adquiriram no processo de produção, sendo que é pelos seus preços de produção que eles são comprados, seria um procedimento metafísico inexplicável ${ }^{45}$.

Assim, o valor do capital variável corresponde ao valor da força de trabalho, que é dado pelo valor do dinheiro pago aos trabalhadores (dos salários), que equivale ao preço de produção dos meios de consumo necessários aos trabalhadores. Este valor pode estar acima ou abaixo do valor destes meios de consumo.

É importante notar que esta interpretação do valor da força de trabalho é consistente com a teoria de que este valor corresponde ao custo de reprodução da força de trabalho, isto é, de que ele é regulado por um determinado padrão de consumo dos trabalhadores; é preciso apenas não considerar que esse padrão se expressa monetariamente no valor de uma cesta de produtos necessários à subsistência dos trabalhadores (como é adequando ao tratamento deste assunto no nível de abstração do Livro I de $O$ Capital) e sim que ele se expressa no preço de produção desta cesta - o que está sem dúvida de acordo com o fato de os trabalhadores comprarem esses produtos por seus preços de produção ${ }^{46}$.

Por outro lado, esta definição do valor do capital variável permite uma precisão na definição da mais-valia. A mais-valia é, naturalmente, igual a valor novo menos capital variável. Mas, como vimos, há mais de um sentido possível para capital variável. O que se

\footnotetext{
45 Do mesmo modo que foi observado com relação ao valor do capital constante, tomar o valor do capital variável como o valor dos meios de subsistência adquiridos pelos trabalhadores só faz sentido em um sistema dos valores separado do sistema dos preços de produção, em que os trabalhadores compram os meios de subsistência por seu valor.

${ }^{46}$ Duncan Foley esclarece esta questão com relação ao chamado new approach [Foley 1982, p. 42], que define o valor da força de trabalho de uma maneira equivalente à defendida acima.
} 
adota na abordagem do sistema único temporal corresponde ao dinheiro pago na forma de salários, que equivale ao preço de produção dos meios de consumo dos trabalhadores, e não ao valor destes meios de consumo.

Embora distinto do tratamento padrão dos economistas, este sentido se torna quase óbvio quando definimos o que é a mais-valia. Mais-valia só pode ser o valor (a quantidade de dinheiro) que fica para o capitalista quando ele desconta do valor adicionado pelos trabalhadores (produtivos) o salário que lhes paga; não faz sentido chamar de mais-valia a diferença entre o valor adicionado pelos trabalhadores e o valor das mercadorias consumidas pelos trabalhadores, se esse valor é diferente do dinheiro que o capitalista lhes paga como salário. Só podemos aplicar a definição da mais-valia como diferença entre o valor adicionado e o valor das mercadorias consumidas pelos trabalhadores se adotamos um nível de abstração mais alto, e supomos que as trocas são feitas segundo os valores das mercadorias. Com a transformação dos valores em preços de produção pensada no nível dos muitos capitais, esta definição de mais-valia fica inteiramente fora de lugar.

Do mesmo modo, a questão de como deve ser entendida a taxa de lucro se torna quase óbvia quando relacionada com os argumentos acima. A taxa de lucro só pode ser entendida como a razão (em determinado período de tempo) entre a mais-valia (no sentido exposto acima) e o capital adiantado, calculado em termos monetários. Calcular o capital adiantado pelo valor dos meios de produção e dos meios de subsistência que formam o conteúdo material do capital constante e do capital variável, quando os capitalistas gastam seu capital segundo o preço de produção de ambos, não faz nenhum sentido. Outra vez: basta recusar o dualismo metodológico da cisão entre valores e preços de produção em dois sistemas distintos para a concepção bortkiewicziana de duas taxas de lucro distintas, em valores e em preços de produção, deixar de ter qualquer sentido.

\subsection{4 - A confusão monetária}

Há outro argumento contra a coerência da transformação dos valores em preços de produção que é usado algumas vezes para reforçar os que foram expostos na subseção 4.2.2. Ele pode ser apresentado a partir de sua origem - Bortkiewicz. No trabalho de 1906-7 podemos ler o seguinte:

Isto não é tudo [Bortkiewicz referiu-se imediatamente antes aos erros supostamente reconhecidos por Marx quanto à falta de transformação dos insumos]: sem entrar em uma dis- 
cussão dos detalhes da transformação dos valores em preços, é possível dar uma prova positiva de que a teoria da igualdade do valor total e do preço total - um teorema ao qual Marx e os marxistas dão tanta importância — é geralmente errada.

Seja $\mathrm{G}$ o bem que serve de medida do valor e do preço. Os números 90 e 92, que indicam o valor e o preço do produto total da esfera 1 , significariam de acordo com isto que este produto total é trocado por 90 unidades de G, de acordo com os princípios do cálculo em valores, e por 92 unidades de $\mathrm{G}$, de acordo com os princípios do cálculo em preços ${ }^{47}$. Tais diferenças entre preço e valor devem-se a diferenças na composição orgânica do capital investido nas várias esferas da produção. Estas diferenças obviamente também dependem, com respeito a seus sinais e à sua magnitude, da composição orgânica do capital investido na produção de $\mathrm{G}$.

Suponhamos agora que este capital tem a composição orgânica mais baixa de todas, isto é, que neste capital o capital constante constitui relativamente uma parte menor que nos outros casos. Com esta suposição, a transição do cálculo em valores para o cálculo em preços deve resultar na troca de todos os bens por mais unidades de G que antes, em outras palavras, todos os preços devem ser maiores do que seus valores correspondentes. O preço total seria conseqüentemente maior que o valor total. No caso oposto, em que o capital que produz $\mathrm{G}$ tem a maior composição orgânica, o preço total seria um número menor que o que expressaria o valor total [Bortkiewicz 1952: 10-11].

Este argumento, chamado por Mandel [1981: 27] de confusão monetária, foi retomado posteriormente por Geoff Hodgson [1974, pp. 383-4], Ian Steedman [1977], Marco Lippi [1979a, p. 78] entre outros autores. Em síntese, diz que a soma dos valores não é em geral igual à soma dos preços de produção porque a transformação do valor do ouro (considerado como o dinheiro) em preço de produção altera suas razões de troca com as demais mercadorias, e são estas razões de troca que constituem os valores (segundo uma regra de troca) e os preços de produção (segundo outra regra de troca), já que o ouro-dinheiro é a unidade de medida ${ }^{48}$.

Trata-se, portanto, de uma discussão que só pode ser posta a partir do ouro como dinheiro; só neste caso faz sentido falar de preço de produção do ouro. Embora estejamos

\footnotetext{
${ }^{47}$ Bortkiewicz faz referências aos números que representam respectivamente o valor (90) e o preço de produção (92) dos produtos da esfera de produção 1 nas tabelas à página 8 de seu trabalho.

${ }^{48}$ Esse argumento é derivado diretamente, portanto, do dualismo metodológico.
} 
hoje em uma economia com um padrão monetário distinto, é útil examinar o argumento no contexto em que foi colocado ${ }^{49}$; isto oferece mais uma oportunidade para mostrar a vantagem da concepção não dualista e temporal da transformação dos valores em preços de produção.

Nos exemplos de Marx da transformação, esta “confusão monetária” não existe: ele não inclui o ouro (a mercadoria-dinheiro) como uma das mercadorias cujo valor é transformado em preços de produção, e explicitamente supõe o valor do dinheiro constante. Mas se incluímos o ouro-dinheiro na transformação, aparecem as duas razões de troca.

Uma maneira de evitar este problema é dizer que preço de produção não é preço, mas sim valor (dimensão: horas de trabalho abstrato), posição adotada por muitos autores, mas que não é a mais consistente com o conjunto da abordagem de Marx (os preços de produção são de fato preços, representam horas de trabalho abstrato expressas em dinheiro $)^{50}$.

A maneira mais correta de enfrentar o argumento da "confusão monetária" é outra. O problema decorrente da eventual transformação do valor do ouro em "preço de produção" só cria dificuldades na versão bortkiewicziana da transformação. Mesmo supondo a existência de um "preço de produção" do ouro, na abordagem não dualista e temporal a divergência de contagens não existe; quando nos situamos no nível dos muitos capitais, não há duas trocas entre as mercadorias e o ouro, uma segundo valores, e outra segundo "preços de produção". Só há uma troca efetiva entre o ouro e as demais mercadorias segundo o preço de produção das mercadorias e o "preço de produção" do ouro. A passagem dos valores aos preços de produção não é a mudança de um sistema dos valores para um sistema dos preços de produção, mas uma sucessão temporal no interior de um mesmo "sistema"; e neste "sistema" só há uma regra de troca, como foi argumentado na subseção 4.3.2. Assim, o valor das mercadorias é definido como

\footnotetext{
${ }^{49}$ Mesmo no contexto do padrão-ouro, pode-se argumentar que o ouro não tinha preço de prdoução, mas apenas valor. Não examinaremos, contudo, esta discussão; admitimos aqui esta parte do argumento, isto é, que o ouro é dinheiro e tem um preço de produção.

${ }^{50}$ Ernest Mandel segue um caminho próximo a esse (no lugar de dizer que o preço de produção é um valor, Mandel tem o cuidado de dizer que "preço de produção não é preço no sentido corrente, de preço de mercado") [Mandel 1981, p. 27].
} 
(...) a relação de troca ideal entre a mercadoria e o ouro que, dada a estrutura de preços, permitiria a seu produtor apropriar-se de toda a mais-valia produzida pelas suas trabalhadoras ou por seus trabalhadores. Seu cálculo se funda em uma estrutura de preços dada para a totalidade do mundo das mercadorias, por exemplo em uma série de relações de troca entre o ouro e as outras mercadorias tal que, no caso de existir uma taxa geral de lucro, todos os produtores - inclusive o produtor de ouro — apropriam-se do lucro médio. Isto significa que os valores das mercadorias calculam-se com a suposição de que o ouro (bem como as outras mercadorias) é trocado em proporções que permitem ao seu produtor embolsar o lucro médio, e que estas proporções são o único valor de troca efetivo entre o ouro e as mercadorias. Esta é uma questão difícil, devido à natureza contraditória da forma de dinheiro do valor [Rodríguez-Herrera 1996, p. 83].

Sendo assim, na passagem do valor a preço de produção não há mudança do padrão monetário. A confusão monetária é uma conseqüência da concepção dualista que contrapõe um sistema dos valores a um sistema dos preços de produção.

\subsection{5 - A transformação no movimento de produção e circulação dos} capitais

Toda esta argumentação fica ainda mais clara quando consideramos o movimento concreto em que os valores se transformam em preços de produção, no interior da circulação dos capitais.

Freeman e Carchedi, criticando o método de determinação de preços a partir de equações simultâneas, dizem de modo expressivo que ele "desconsidera tanto o movimento quanto o tempo, o verdadeiro estofo de que é feita a realidade" [1996b, p. XI]. Ao contrário dos neoclássicos ou dos bortkiewiczianos, Marx destaca justamente tempo e movimento. Daí tratar o processo de formação do valor dentro do movimento da circulação do capital. Após ser introduzido no Capítulo IV do Livro I, o estudo da circulação do capital é retomado e ampliado nos primeiros capítulos do Livro II d'O Capital. E aí lemos:

O capital, enquanto valor que se valoriza, (...) é um movimento, um processo de circulação por diferentes estágios (...). Só pode, por isso, ser entendido como movimento e não como coisa em repouso. (...) O valor percorre aqui diferentes formas, diferentes movimentos, nos quais se mantém e, ao mesmo tempo, se valoriza, aumenta [O Capital II-III: 73]. 
O ponto de partida do processo de circulação e valorização do capital é o dinheiro. Esse processo, inicialmente descrito no Capítulo IV do Livro I como $D-M-D$ ', é depois, no Capítulo I do Livro II, representado como $D-M \ldots P \ldots M^{\prime}-D^{\prime}$.

Nos capítulos iniciais do Livro I, a mercadoria é simplesmente um valor de uso que é produzido para a venda (adquirindo por isto um duplo caráter, valor de uso e valor). A partir do capítulo IV do Livro I (Como o dinheiro se transforma em capital), há uma redução do nível de abstração, uma vez que a relação capital $x$ trabalho é introduzida na análise. A produção da mercadoria, então, passa a ser tratada no interior do processo de circulação e valorização dos capitais; a circulação das mercadorias passa a ser subordinada e incluída no ciclo do capital, $D-M-D$ '. A mercadoria já é encarada como produto do capital, e mais, é ela própria um momento do ciclo do capital, uma das formas que ele assume. As conseqüências desta mudança para o conceito de valor se manifestam quando, estudada já a circulação do capital no Livro II, entramos no Livro III, e começam a ser consideradas as "formas concretas que surgem do movimento do capital como um todo" [O Capital III-IV, p. 21], e é incluída na análise a existência de diversos capitais que concorrem em busca de maiores taxas de lucro. É necessário introduzir determinações adicionais. As mercadorias não serão em geral vendidas por seu valor, mas sim por seu preço de produção. Cada capitalista recebe então uma fração da mais-valia global proporcional a todo o capital investido (bem como a seu tempo de rotação).

O processo de formação do valor das mercadorias transcorre em uma seqüencia temporal, não pode ser compreendido em termos simultâneos. Ele é descrito no Livro II nas várias figuras do ciclo do capital. O ciclo do capital-dinheiro, que é o mais apropriado para estudar as variações quantitativas que se dão no processo de formação dos valores das mercadorias, é esquematizado da seguinte maneira: $D-M(M P, F T) \ldots P \ldots M^{\prime}-D^{\prime}$. Isto significa que o ciclo começa na circulação: uma quantidade de dinheiro $(D)$, possuída inicialmente por um capitalista, compra mercadorias $(M)$, ou seja, meios de produção e força de trabalho. Passamos então ao momento da produção. As mercadorias adquiridas pelo capitalista funcionam como capital produtivo $(P)$. Como resultado do processo de produção, formam-se novas mercadorias, que incorporam já uma mais-valia $\left(M^{\prime}\right)$. O processo de produção é pois representado por $M . . . P$...M'. Voltamos então à circulação: as mercadorias produzidas $\left(M^{\prime}\right)$ são vendidas e o capitalista volta a ter capital na forma de dinheiro $\left(D^{\prime}\right)$. 
Esta análise, realizada nos capítulos iniciais do Livro II de $O$ Capital, supõe sempre que as mercadorias se vendem por seu valor; é portanto insuficiente para tratar da formação dos preços de produção. Mas não é difícil modificá-la para levar em conta a transformação dos valores em preços de produção. Para isto, basta escrever a fórmula do ciclo do capital-dinheiro da seguinte maneira: $D-M(M P, F T) \ldots P \quad \ldots\left(M^{\prime}\right) M^{\prime *}-D^{\prime *}$. Isto significa que, no segundo momento da circulação, anteriormente representado por $M^{\prime}$ D', as mercadorias passam a ser vendidas por seus preços de produção, que representamos por $M^{\prime *}$. Com isto acrescentamos mais uma determinação na fórmula, a transformação dos valores em preços de produção, representada por $\left(M^{\prime}\right) M^{\prime *}$.

Uma reflexão sobre o sentido desta fórmula torna muito clara a interpretação do significado do valor do capital constante, do valor do capital variável, do valor das mercadorias produzidas e da mais-valia defendida nas duas seções anteriores. Partimos de uma quantidade de capital-dinheiro que se transforma em mercadorias, meios de produção e força de trabalho. Nessa passagem, não há alterações do valor; conseqüentemente, o valor do capital constante e o valor do capital variável são dados (mesmo comprando mercadorias por preços de produção que diferem dos valores). Em seguida, no curso do processo de produção, o valor do capital constante consumido (trabalho morto) é transferido para os produtos, e o trabalho vivo realizado acrescenta valor novo. O valor dos produtos, portanto, é definido pela soma destas duas quantidades de trabalho. A mais-valia é a diferença entre o valor novo e o valor do capital variável, calculado naturalmente segundo o dinheiro que o capitalista paga por ele - seu custo efetivo. Mas ao vender suas mercadorias, o capitalista obterá uma fração diferente da mais-valia produzida por "seus" trabalhadores: há uma redistribuição de mais-valia, os valores são transformados em preços de produção.

Com esta interpretação, o valor do capital constante e do capital variável, a massa global de mais-valia e a taxa média (ou global, ou geral) de lucro são invariantes na transformação. Esta é realmente um processo de redistribuição de parte do valor (da mais-valia) já definido na produção. E não há nenhuma inconsistência.

\section{4 - EXEMPLO NUMÉRICO DE UMA TRANSFORMAÇÃO COMPLETA DOS} VALORES EM PREÇOS DE PRODUÇÃO EM UM SISTEMA ÚNICO TEMPORAL

Um exemplo numérico ajuda a explicitar a abordagem do sistema único temporal. 


\section{Tabela 1}

\begin{tabular}{|c|c|c|c|c|}
\hline & $\mathrm{I}$ & II & III & $\Sigma$ \\
\hline (1) Valor do capital constante adiantado & 145 & 175 & 70 & 390 \\
\hline (1b) Valor dos meios de produção adiantados & $?$ & $?$ & $?$ & $?$ \\
\hline (2) Valor do capital constante consumido & 92 & 60 & 50 & 202 \\
\hline (2b) Valor dos meios de produção consumidos & $?$ & $?$ & $?$ & $?$ \\
\hline (3) Valor do capital variável & 55 & 25 & 30 & 110 \\
\hline (3b) Valor dos meios de consumo consumidos & $?$ & $?$ & $?$ & $?$ \\
\hline (4) Valor do capital adiantado [(1) + (3)] & 200 & 200 & 100 & 500 \\
\hline (5) Valor novo & 110 & 50 & 60 & 220 \\
\hline (6) Preço de custo $[(2)+(3)]$ & 147 & 85 & 80 & 312 \\
\hline (7) Mais-valia [(5) - (3)] & 55 & 25 & 30 & 110 \\
\hline (8) Valor dos produtos $[(2)+(5)]$ & 202 & 110 & 110 & 422 \\
\hline (9) Taxa média de lucro $[\Sigma(7) / \Sigma(4)]$ & $22,0 \%$ & $22,0 \%$ & $22,0 \%$ & $22,0 \%$ \\
\hline (10) Lucro $[(4) \times(9)]$ & 44 & 44 & 22 & 110 \\
\hline (11) Preço de produção [(6) + (10)] & 191 & 129 & 102 & 422 \\
\hline (12) Desvios [(11) - (8)] & -11 & +19 & -8 & 0 \\
\hline
\end{tabular}

Partimos da tabela de Marx modificada por Bortkiewicz [1952, pp. 8-9]. Em primeiro lugar, ele altera ligeiramente os números do capital constante consumido nos setores II e III, de 51 e 51 para 50 e 52. Em seguida, supõe que os setores I e V de Marx produzem bens de consumo dos trabalhadores; deste modo a soma de seu produto $(90+20)$ corresponde exatamente aos salários (110). Supõe também que os setores III e IV produzem bens de produção; deste modo o seu produto somado $(132+70)$ corresponde ao valor do capital constante consumido (202). Finalmente, supõe que o setor II produz bens de luxo (meios de consumo dos capitalistas); seu produto (110) corresponde exatamente à soma das maisvalias. Deste modo, a tabela de 5 setores de Marx é transformada em uma tabela de 3 departamentos, em equilíbrio de reprodução simples. A taxa de mais-valia é de $100 \%$ em todos os departamentos. Reproduzimos a tabela resultante abaixo (Tabela 1), considerando, 
como de costume, que o Departamento I produz meios de produção, o Departamento II meios de consumo dos trabalhadores, e o Departamento III meios de consumo dos capitalistas (bens de luxo). Acrescentamos três linhas (valor dos meios de produção adiantados, valor dos meios de produção consumidos e valor dos meios de consumo dos trabalhadores); de acordo com a interpretação que estamos defendendo, seus valores diferem, respectivamente, do valor do capital constante adiantado, do valor do capital constante consumido e do valor do capital variável. Como Marx não especificou estes valores, as caselas destinadas a eles permanecem com uma interrogação. Outra diferença em relação à apresentação de Bortkiewicz é que consideramos que os valores são expressos em dinheiro.

Vale notar uma curiosidade: é o Departamento II, que produz meios de consumo, que tem a maior composição orgânica (175/25), e não o Departamento I, como é mais comum. Este último tem uma composição orgânica de 145/55, e o Departamento III de $70 / 30$.

De acordo com a análise de Bortkiewicz, esta tabela tem dois problemas: inconsistência lógica (pela não transformação do valor dos meios de produção e dos meios de consumo em preços de produção), e violação do equilíbrio da reprodução. Com a abordagem do sistema único temporal, já que consideramos que os valores do capital constante e do capital variável correspondem aos preços de produção dos meios de produção e dos meios de consumo dos trabalhadores, respectivamente, e que portanto os valores dos meios de produção e dos meios de consumo já foram transformados em preços de produção no período anterior, a inconsistência lógica desaparece. E todas as equações que definem o algoritmo de transformação de Marx (equações de 1 a 6 da subseção 4.2.1) permanecem válidas, com um subscrito temporal t nas variáveis. Acrescentamos as seguintes equações:

(7) Valor do capital constante adiantado em um setor = preço de produção (unitário) dos meios de produção no período anterior multiplicado pela quantidade física de meios de produção adiantados: $a_{\mathrm{t} i}=p_{\mathrm{I}(\mathrm{t}-1) i} q_{m p a \mathrm{t} i}$;

(8) Valor do capital constante consumido em um setor = preço de produção (unitário) dos meios de produção no período anterior multiplicado pela quantidade física de meios de produção consumidos: $c_{\mathrm{t} i}=p_{\mathrm{I}(\mathrm{t}-1) i} q_{m p c} \mathrm{t} i$;

(9) Valor do capital variável em um setor = preço de produção (unitário) dos meios de consumo no período anterior multiplicado pela quantidade fisica de meios de consumo 
dos trabalhadores consumidos: $\quad \mathrm{V}_{\mathrm{t} i}=p_{\mathrm{II}(\mathrm{t}-1) i} q_{m c \mathrm{t} i}$ (supondo que os trabalhadores adquirem os meios de consumo no início do período).

Por outro lado, não há de fato equilíbrio na reprodução simples; como vimos, Marx não vinculou a transformação aos esquemas de reprodução. Isto não é um erro: não há obrigação de que haja equilíbrio geral entre oferta e demanda; em geral ele não ocorre. Contudo, fica a questão: a hipótese de equilíbrio é compatível com a abordagem marxiana? É fácil mostrar que sim, utilizando o método do próprio Bortkiewicz, e corrigindo, segundo a interpretação que defendemos, algumas das definições que ele utiliza.

Para isto, é preciso estabelecer quais são as quantidades físicas produzidas e trocadas; Marx não as especificou. Pela tabela de Bortkiewicz construída a partir da de Marx, sabemos o valor do capital constante adiantado (que corresponde, de acordo com a equação 7 acima, ao produto da quantidade física de meios de produção adiantados por seu preço de produção unitário no período anterior), o do capital constante consumido (que corresponde, de acordo com a equação 8 acima, ao produto da quantidade física de meios de produção adiantados por seu preço de produção unitário no período anterior) e o do capital variável (que corresponde, de acordo com a equação 9 acima, ao produto da quantidade física de meios de consumo dos trabalhadores consumidos por seu preço de produção unitário no período anterior). Podemos fazer, então, os preços de produção unitários do período anterior iguais a 1,00 — tanto para os meios de produção quanto para os meios de consumo dos trabalhadores; isso faz que suas respectivas quantidades físicas correspondam exatamente aos números dos valores de Marx-Bortkiewicz. Para as mercadorias produzidas, suponhamos do mesmo modo que seu valor unitário é igual a 1,00, fazendo suas quantidades físicas corresponderem também aos números dos valores da tabela anterior ${ }^{51}$. Os preços de produção resultantes da transformação serão, é claro, diferentes tanto dos valores quanto

\footnotetext{
${ }^{51}$ Naturalmente, de modo geral os valores de um período não serão iguais aos preços de produção do período anterior. Mas não há impossibilidade de que isto aconteça. Por outro lado, a suposição de que tanto os preços de produção dos meios de produção e dos meios de consumo dos trabalhadores do período anterior quanto os valores das mercadorias produzidas no período em curso são iguais a 1,00 equivale, naturalmente, à de que os meios de produção e os meios de consumo dos trabalhadores são comprados por seus valores, e estes valores são, tanto no período em curso quanto no anterior, iguais a 1,00; esta segunda hipótese pode parecer preferível por ser mais simples. Não a adotamos, no entanto, para manter a coerência da interpretação do sistema único temporal.
} 
dos preços de produção do período anterior ${ }^{52}$. Estas escolhas têm a vantagem de manter um vínculo entre o nosso exemplo e a tabela de Marx-Bortkiewicz, e além disso a de salientar que, no método deste último, os "valores" funcionam exatamente como especificação de quantidades físicas.

Assim, temos o quadro (Tabela 2, abaixo) de quantidades físicas (e portanto, implicitamente, das relações técnicas entre elas), que passa a ser nosso ponto de partida. Nosso problema agora, portanto, é o de encontrar valores para que as quantidades físicas de mercadorias sejam transformados, segundo nossa abordagem, em preços de produção que configurem equilíbrio em reprodução simples.

\section{Tabela 2}

\begin{tabular}{||l|l|l|l|l||}
\hline & I & II & III & $\Sigma$ \\
\hline Meios de produção adiantados & 145 & 175 & 70 & 390 \\
\hline Meios de produção consumidos & 92 & 60 & 50 & 202 \\
\hline Meios de consumo & 55 & 25 & 30 & 110 \\
\hline Bens de luxo & 55 & 25 & 30 & 110 \\
\hline Produto & 202 & 110 & 110 & ---- \\
\hline
\end{tabular}

Pela abordagem do sistema único temporal, os valores de cada período dependem dos preços de produção dos meios de produção e dos meios de consumo do período anterior. Contudo, na hipótese de reprodução simples equilibrada, tanto as quantidades produzidas quanto os preços de produção são constantes; estes podem ser calculados através de um sistema de equações simultâneas de tipo bortkiewicziano ${ }^{53}$ :

$$
q_{m p c . i} p_{\mathrm{I}}+q_{m c . i} p_{\mathrm{II}}+\left(q_{m p a . i} p_{\mathrm{I}}+q_{m c . i} p_{\mathrm{II}}\right) l^{\prime}=q_{p i} p_{i}
$$

\footnotetext{
${ }^{52}$ Esses novos preços de produção unitários serão então, respectivamente, 0,9455, 1,1727 e 0,9273.

${ }^{53}$ Estas equações não são idênticas às equações bortkiewiczianas usuais porque fazem a distinção entre capital constante adiantado e consumido. No entanto, seu princípio é o mesmo. Estabelecemos equações para três departamentos, como Bortkiewicz, mas é possível generalizá-las para $n$ setores.
} 
onde $q_{m p c . i}$ é quantidade de meios de produção consumidos no setor $i, q_{m p a . i}$ é a quantidade de meios de produção adiantados no setor $i, p_{\text {I }}$ é o preço de produção dos meios de produção, $q_{m c . i}$ a quantidade de meios de consumo consumidos pelos trabalhadores do setor $i, p_{\mathrm{II}}$ é o preço de produção dos meios de consumo, l' a taxa média de lucro, $q_{p i}$ é a quantidade produzida no setor $i$, e $p_{i}$ é seu preço de produção; como trabalhamos com um esquema de três departamentos, $i$ pode assumir os valores I, II e III.

Para as quantidades físicas que especificamos, este sistema é:

$$
\begin{aligned}
& \left(92 p_{\mathrm{I}}+55 p_{\mathrm{II}}\right)+\left(145 p_{\mathrm{I}}+55 p_{\mathrm{II}}\right) l^{\prime}=202 p_{\mathrm{I}} \\
& \left(60 p_{\mathrm{I}}+25 p_{\mathrm{II}}\right)+\left(175 p_{\mathrm{I}}+25 p_{\mathrm{II}}\right) l^{\prime}=110 p_{\mathrm{II}} \\
& \left(50 p_{\mathrm{I}}+30 p_{\mathrm{II}}\right)+\left(70 p_{\mathrm{I}}+30 p_{\mathrm{II}}\right) l^{\prime}=110 p_{\mathrm{III}}
\end{aligned}
$$

Temos um sistema de três equações e quatro incógnitas (os três preços de produção unitários e a taxa média de lucro), suficiente para determinar os preços relativos e a taxa média de lucro ${ }^{54}$. Para chegarmos aos preços absolutos, devemos acrescentar um critério de normalização. Matematicamente, podemos escolher inúmeros. Optamos pela equação:

$\Sigma$ valor novo $=\Sigma v+\Sigma l=220$

O valor novo total de 220 é o mesmo da tabela de Marx-Bortkiewicz. Isto significa que a expressão em dinheiro da capacidade de criar valor do trabalho humano na nossa tabela modificada é a mesma (supondo que o número de trabalhadores que trabalham em cada setor, a jornada de trabalho, e a intensidade do trabalho no nosso exemplo são iguais aos da tabela de Marx-Bortkiewicz).

$$
\begin{aligned}
& \Sigma v+\Sigma l=220 \text { se traduz na equação: } \\
& 110 p_{\mathrm{II}}+\left(390 p_{\mathrm{I}}+110 p_{\mathrm{II}}\right) l^{\prime}=220 .
\end{aligned}
$$

Resolvendo esta equação junto com as três anteriores, encontramos:

$$
l^{\prime}=0,207 ; \quad p_{\mathrm{I}}=0,914 ; \quad p_{\mathrm{II}}=1,101 ; \quad p_{\mathrm{III}}=0,899 \text {. }
$$

Para chegarmos à nossa nova tabela, multiplicamos em primeiro lugar as quantidades físicas dos meios de produção (adiantados e consumidos em cada setor e no total) e dos

\footnotetext{
${ }^{54}$ Uma vez que este sistema pode ser escrito como um sistema homogêneo nas incógnitas $p_{\mathrm{I}}, p_{\text {II }}$ e $p_{\text {III }}$.
} 
meios de consumo dos trabalhadores (em cada setor e no total) pelos preços de produção unitários correspondentes. Encontramos as linhas (1), (2) e (3). A linha (5), a do valor novo, é a mesma da tabela de Marx-Bortkiewicz, por construção. As linhas (4), (6) e as seguintes são encontradas de acordo com as indicações dadas na própria tabela.

\section{Tabela 3}

\begin{tabular}{|c|c|c|c|c|}
\hline & $\mathrm{I}$ & II & III & $\Sigma$ \\
\hline (1) Valor do capital constante adiantado & 132,50 & 160,00 & 64,00 & 356,50 \\
\hline (1b) Valor dos meios de produção adiantados & 139,30 & 168,20 & 67,30 & 374,80 \\
\hline (2) Valor do capital constante consumido & 84,10 & 54,80 & 45,70 & 184,60 \\
\hline (2b) Valor dos meios de produção consumidos & 88,40 & 57,70 & 48,00 & 194,10 \\
\hline (3) Valor do capital variável & 60,50 & 27,50 & 33,10 & 121,10 \\
\hline (3b) Valor dos meios de consumo consumidos & 52,40 & 23,80 & 28,60 & 104,80 \\
\hline (4) Valor do capital adiantado [(1) + (3)] & 193,00 & 187,50 & 97,10 & 477,60 \\
\hline (5) Valor novo & 110,00 & 50,00 & 60,00 & 220,00 \\
\hline (6) Preço de custo $[(2)+(3)]$ & 144,60 & 82,30 & 78,80 & 305,70 \\
\hline (7) Mais-valia [(5) - (3)] & 49,50 & 22,50 & 26,90 & 98,90 \\
\hline (8) Valor dos produtos $[(2)+(5)]$ & 194,10 & 104,80 & 105,70 & 404,60 \\
\hline (9) Taxa média de lucro $[\Sigma(7) / \Sigma(4)]$ & $20,7 \%$ & $20,7 \%$ & $20,7 \%$ & $20,7 \%$ \\
\hline (10) Lucro [(4) x (9)] & 40,00 & 38,80 & 20,10 & 98,90 \\
\hline (11) Preço de produção [(6) + (10)] & 184,60 & 121,10 & 98,90 & 404,60 \\
\hline (12) Desvios [(11) - (8)] & $-9,50$ & 16,30 & $-6,80$ & 0,00 \\
\hline
\end{tabular}

Finalmente, para encontrarmos as linhas $(1 b),(2 b)$ e $(3 b)$, necessitamos primeiro achar os valores unitários dos meios de produção e dos meios de consumo, o que conseguimos dividindo os valores dos produtos dos Departamentos I e II, dados nas duas primeiras colunas da linha (8), por suas quantidades físicas. Encontramos, respectivamente, os 
valores unitários de 0,9609 e $0,9527^{55}$. Multiplicamos então 0,9609 pelas quantidades físicas correspondentes às linhas (1) e (2), e 0,9527 pelas quantidades físicas correspondentes à linha (3).

Os números foram aproximados até a primeira casa decimal; acrescentamos um zero na segunda casa apenas para reforçar a característica de que são valores e preços expressos em dinheiro ${ }^{56}$.

Lembremos que os valores dos meios de produção consumidos e adiantados, e os valores dos meios de consumo consumidos pelos trabalhadores, colocados em itálico, não entram no cálculo, pois já foram transformados em preços de produção no período anterior.

Embora tenhamos encontrado os valores das mercadorias produzidas após os preços de produção e a taxa média de lucro (uma vez que, como as quantidades físicas e os preços de produção são constantes, os preços de produção e a taxa média de lucro do período $t$ são iguais aos preços de produção e à taxa média de lucro do período $t$-1), a transformação dos valores em preços de produção segundo o método de Marx se faz, naturalmente, nesta tabela (ou seja, neste sistema único temporal) com a passagem da linha (8) para a linha (11), a partir do cálculo da taxa média de lucro da forma indicada $\left(l^{\prime}=[\Sigma(7) /\right.$ $\Sigma(4)])$.

Ou seja: o que fizemos resolvendo o sistema de equações simultâneas acima foi raciocinar do fim para o começo, partindo do resultado a que queríamos chegar.

É fácil constatar que, como queria Bortkiewicz, há equilíbrio em reprodução simples. O valor total do capital constante consumido $(184,60)$ é igual ao preço de produção do produto do departamento I; o valor total do capital variável consumido $(121,10)$ é igual

\footnotetext{
55 Não temos necessidade de usar na tabela o valor unitário dos bens de luxo, que é de 0,9609 (por pura coincidência, este valor com quatro casas decimais é igual ao valor unitário dos meios de produção).

${ }^{56}$ Para que os valores e os preços de produção sejam expressos em dinheiro, é indiferente como estabelecemos a unidade monetária: ela tanto pode ser alguma quantidade de alguma das mercadorias que entram na nossa tabela, quanto alguma unidade legal puramente fiduciária. Uma vez que não há trocas segundo os valores, a unidade monetária pode ser uma mercadoria cujo valor é transformado em preço de produção sem que isto crie qualquer dificuldade adicional, como vimos na subseção 4.3.4. Podemos escolher, portanto, à moda de Bortkiewicz, uma unidade da mercadoria do Departamento III como unidade monetária: como seu preço de produção é 1,00 os valores e preços serão os da tabela.
} 
ao preço de produção do produto do departamento II; o valor total dos lucros $(98,90)$ é igual ao preço de produção do produto do departamento III.

Com o tratamento da transformação explicitado acima, é evidente que se verificam as duas identidades, $\Sigma P=\Sigma M$ (no caso, 404,60) e $\Sigma l=\Sigma m$ (no caso, 98,90). A razão é clara: o que se fez foi redistribuir um valor (parte da mais-valia) já definido anteriormente. Igualmente importante para a coerência da teoria de Marx é o fato de que só há uma taxa média de lucro no sistema, de 20,7\%. Não há diferença entre uma "taxa média de lucro em valor" e uma "taxa média de lucro em preços de produção". O cálculo da taxa média de lucro em valores ou em preços de produção é o mesmo porque, de um lado, $\Sigma m=\Sigma l$, e, de outro, o valor total do capital adiantado, $\Sigma C$, não tem de ser transformado em preços de produção; ele é igual ao produto da quantidade física dos meios de produção adiantados pelo seu preço de produção no período anterior ${ }^{57}$, o mesmo acontecendo com o valor do capital variável $^{58}$.

\footnotetext{
${ }^{57}$ No caso da nossa tabela, de todos os períodos.

${ }^{58}$ Há algumas diferenças entre nossa Tabela 3 e a Tabela 1, de Marx-Bortkiewicz. Por exemplo: a massa de mais-valia (total e de cada setor) se reduz: sua soma passa de 110 para 98,90. Isto se explica porque $o$ valor do capital variável aumenta, o que se deve ao fato de que o preço de produção unitário dos meios de consumo dos trabalhadores (do período anterior) aumenta, passando de 1,00 para 1,101, e porque supomos que os trabalhadores mantêm seu consumo em termos reais. Além disso, a queda da massa de mais-valia e o aumento do capital variável fazem que a taxa de mais-valia $(\mathrm{m} / \mathrm{v}$, ou seja, 98,90/121,10) caia de 100\%, no exemplo de Marx que serviu de ponto de partida, para 82\%. A queda da massa de mais-valia leva também à queda da taxa média de lucro: era antes de $22 \%$, e passou a $20,7 \%$. Isto apesar de o valor total do capital adiantado cair, de 500 para 477,60. Entre dois efeitos contrários, predomina o da queda da massa de maisvalia. Contudo, a redução do valor total do capital adiantado, e o aumento do valor do capital variável, fazem que a queda da taxa média de lucro seja muito menos pronunciada do que a da taxa de mais-valia. Naturalmente, nenhuma destas alterações cria qualquer problema lógico ou teórico para a teoria do valor e dos preços de produção de Marx. A tabela de Marx-Bortkiewicz e a nossa têm em comum as quantidades físicas (e a expressão monetária do valor novo), mas diferem no aspecto fundamental de que os preços de produção da primeira não conduzem ao equilíbrio entre oferta e demanda, não são preços estacionários, e os da segunda sim. Não há nenhuma razão, portanto, para que os valores, os preços de produção, a massa de mais-valia, a taxa de mais-valia, as taxas de lucro ou as composições orgânicas devessem coincidir.
} 


\section{5 - DIFERENÇAS ENTRE A ABORDAGEM DO SISTEMA ÚNICO}

\section{TEMPORAL E A ABORDAGEM BORTKIEWICZIANA-SRAFFIANA}

Aqui faremos um rápido comentário a respeito de uma questão que merece muito maior aprofundamento. O exemplo numérico da seção anterior, construído para explicitar a abordagem do sistema único temporal, inclui o cálculo de preços de produção segundo a abordagem bortkiewicziana. O que muda em relação a esta abordagem não é o cálculo dos preços de produção de equilíbrio, mas sim o que se entende por valor.

As supostas inconsistências de Marx são eliminadas a partir de diferenças na definição do valor do capital constante, do valor do capital variável, do valor das mercadorias produzidas, e conseqüentemente da mais-valia e da taxa de lucro. Tudo parece, portanto, não passar de mudanças convenientes de definições. Qual seria a vantagem, então, da nova abordagem?

Em primeiro lugar, adotar uma concepção do que são os valores de modo a mostrar a consistência da teoria marxiana do valor não é pouca coisa. As mudanças no entendimento do que são os valores não constituem um truque; têm justificativas sólidas na concepção teórica de Marx.

Mas as diferenças nas definições que envolvem o valor implicam uma profunda diferença de abordagem. A abordagem bortkiewicziana-sraffiana define os preços de produção e os valores como puras relações de troca (ou como índices de relações de troca), e depende estritamente portanto da hipótese de trocas em situação de equilíbrio geral: só assim os preços de produção (supostos constantes) podem ser calculados a partir dos esquemas de reprodução. Além disso, pressupõe preços constantes (estacionários), ou seja, ausência de progresso técnico. Os preços de produção como definidos por Marx, ao contrário, não dependem para nada da hipótese de equilíbrio. Tampouco precisam ser estacionários. A abordagem marxista tem, portanto, a grande vantagem de ser mais geral; as mercadorias podem perfeitamente ser vendidas por preços de não-equilíbrio. Os preços de produção (bem como a taxa média de lucro) bortkiewiczianos-sraffianos podem ser entendidos como casos especiais dos preços de produção (e da taxa média de lucro) de Marx: correspondem aos casos de equilíbrio geral entre oferta e demanda, e em que ademais os preços ficam constantes. 
A maior generalidade da abordagem marxista significa que ela é muito mais realista e aberta. Pode explicar, por exemplo, mecanismos de variações de preços em que tenha vigência a tendência à igualação da taxa de lucro, mas em que ela não chegue a seu termo. Não há razão, além disso, para os preços de produção, mesmo tendencialmente, convergirem para os bortkiewiczianos-sraffianos: as relações técnicas entre insumos e produtos não são tão rígidas e são afetadas pelos preços relativos; a tendência à igualação das taxas de lucro e ao equilíbrio entre oferta e demanda para as várias mercadorias produzidas tanto pode se exercer por variações nos preços (única hipótese consistente com a abordagem bortkiewicziana, em que oferta e demanda, isto é, quantidades físicas produzidas e consumidas são dadas) quanto por variações nas quantidades produzidas. Em particular, a relação entre meios de consumo dos trabalhadores e mercadorias produzidas (aliás, é um abuso tratá-la como relação técnica) pode evidentemente variar, mesmo sem modificações técnicas que expressem variações de produtividade, a partir do esforço dos capitalistas para aumentar a intensidade do trabalho (e eventualmente a jornada de trabalho) e da resistência dos trabalhadores a isto.

Outra grande vantagem da abordagem baseada em Marx é que abre o caminho para o tratamento efetivo do dinheiro. Isto acontece pela sua conceituação, a partir do valor das mercadorias, como concretização da substância social do valor que é o trabalho humano abstrato; e pela possibilidade de tratar situações de não-equilíbrio. As duas questões, como vimos, estão estreitamente relacionadas. A abordagem bortkiewicziana-sraffiana, bem como a walrasiana, com suas concepções do dinheiro como numerário, do preço como pura relação de troca, e com sua abordagem centrada no equilíbrio geral de oferta e demanda, têm grandes dificuldades para tratar de questões monetárias. 


\section{CAPÍTUlO 5 - VALORES, PREÇOS E A LEI DO VALOR}

\section{1 - INTRODUÇÃO}

Este capítulo procura mostrar como a abordagem deste trabalho constitui um quadro adequado para tratar algumas questões relacionadas entre si: mais-valia extra e superlucros, as transferências de valor na circulação, a lei do valor e as relações internacionais.

A seção 5.2 retoma a questão da determinação do tempo de trabalho socialmente necessário, incluindo um fato que tem uma importância fundamental: as diferenciações dos valores entre valores individuais e valores sociais (ou valores de mercado), que dão origem à mais-valia extra e aos sobrelucros. A concepção de que a mais-valia extra seria decorrente de transferências de valor é comentada e criticada. A seção 5.3 trata da diferenciação entre valores e preços. Esta não se reduz, na teoria de Marx, às distinções mais conhecidas entre valores, preços de produção e preços de mercado; inclui a distinção entre "preços de produção no sentido estrito" e "preços comerciais", além de se manifestar na formação de preços de monopólio (tema não trabalhado por Marx, mas mencionado explicitamente, e com um sentido teórico muito claro). O desvio do preço com relação ao valor realiza uma transferência de valor na circulação.

As diferenças entre valores individuais e valores sociais, e as diferenças entre preços e valores, são portanto teórica e praticamente distintas. Estas implicam transferências de valor na circulação; aquelas, decorrentes, sobretudo, de desigualdades tecnológicas, dizem respeito a diferenciações na própria capacidade de produzir valor. Ambas são melhor entendidas com caracterização do valor como substância social; ambas são fundamentais para a explicação das desigualdades regionais e internacionais das economias capitalistas.

A seção 5.4 discute o significado da lei do valor, inicialmente no plano nacional, chamando a atenção para suas diversas dimensões (formação do valor, distribuição do trabalho e minimização do tempo de trabalho), e para o fato de que ela diz respeito à produção. A seção 5.5 propõe uma abordagem para os valores e preços internacionais, a partir de um comentário de parágrafos bastante fragmentários de Marx. Seu tema central é a taxa de câmbio como expressão das distintas capacidades nacionais de criar valor internacional. 
Revê brevemente o debate em torno do intercâmbio desigual. A seção 5.6 retoma a discussão do significado da lei do valor, ampliando-a para o contexto internacional.

\section{2 - TEMPO DE TRABALHO SOCIALMENTE NECESSÁRIO E MAIS-}

\section{VALIA EXTRA}

\subsection{1 - Referências sobre este tema em $O$ Capital}

Nos Capítulos 1 e 3 tratamos da determinação do tempo de trabalho socialmente necessário e, portanto, da determinação da magnitude do valor, com base nos desenvolvimentos realizados nos primeiros capítulos do Livro I de $O$ Capital. No entanto, há aspectos da questão que não são esclarecidos aí; por isto, Marx a retoma no Livro III, no contexto na análise dos "muitos capitais" e da concorrência entre eles. É necessário reexaminar aqui este tema.

É importante destacar que toda a discussão realizada nesta seção se refere ao quadro nacional, entendido como aquele em que o espaço econômico é unificado (salários e preços unificados, etc.). Os casos em que queremos distinguir entre regiões de um mesmo país que constituem espaços econômicos diferenciados assemelham-se ao tratamento das diferenças entre países, que analisaremos na seção 5.4.

\section{a) No Capítulo I do Livro I}

Como vimos no Capítulo 1, subseção 1.2.1, e no Capítulo 3, subseções 3.3.3 e 3.3.4, a magnitude do valor é dada pelo "quantum nele contido da 'substância constituidora do valor', o trabalho", e "a própria quantidade de trabalho é medida pelo seu tempo de duração" [O Capital I-I, p. 47; El Capital I-I, p. 48]. Mas o tempo de trabalho efetivamente contado não se mede diretamente pelas horas trabalhadas; exige um processo de homogeneização, de igualação social. Em primeiro lugar, é preciso que seja estabelecido o tempo de trabalho socialmente necessário, em cuja quantificação já é preciso efetuar uma tripla homogeneização: das condições técnicas, da habilidade 
(individual) e da intensidade do trabalho ${ }^{1}$. Além disto, é preciso ainda efetuar a redução do trabalho complexo — ou seja, qualificado - a trabalho simples ${ }^{2}$.

É importante destacar aqui três pontos.

O primeiro é que redução do (tempo de) trabalho individual a (tempo) socialmente necessário é uma coisa distinta da redução de trabalho complexo a trabalho simples. A diferença entre a maior habilidade individual — que é uma das questões resolvidas na determinação do tempo de trabalho socialmente necessário - e a maior qualificação é clara: a segunda decorre de maior aprendizado.

O segundo, a de que igualação dos trabalhos se faz a partir da igualação das mercadorias (tema abordado no Capítulo 3, subseção 3.3.2). Há uma conseqüência clara disto: se os valores das mercadorias são iguais, o trabalho (socialmente reconhecido) objetivado nelas é obrigatoriamente igual. Com maior razão, duas mercadorias iguais só podem representar socialmente a mesma quantidade de trabalho abstrato.

O terceiro ponto é que, como a quantificação do valor se faz a partir do tempo de trabalho socialmente necessário, há uma distinção entre maior produção de valores de uso e maior produção de valor: a primeira não leva obrigatoriamente à segunda. Marx, ao analisar o duplo caráter do trabalho representado nas mercadorias, destacou este aspecto, que examinamos na subseção 3.2.4 do Capítulo 3.

\section{b) No Capítulo X do Livro I}

O tema da produção de valor é retomado no Capítulo X do Livro I, no contexto da discussão da produção da mais-valia relativa. Marx esclarece que está antecipando algumas questões que só poderiam ser tratadas com mais propriedade no Livro III (no contexto da análise da concorrência):

O modo como as leis imanentes da produção capitalista aparecem no movimento externo dos capitais, como se impõem como leis coercitivas da concorrência e assim surgem na

\footnotetext{
${ }^{1} \mathrm{O}$ que inclui a normalização (isto é, a redução do tempo de trabalho individual a tempo de trabalho socialmente necessário - cf. subseção 3.3.3) e a sincronização (isto é, a determinação dos valores das mercadorias pelo tempo de trabalho necessário à sua produção no presente — cf. subseção 3.3.5).

${ }^{2}$ Cf. subseção 3.3.4.
} 
consciência do capitalista individual como motivos impulsionadores não é para ser apreciado agora, mas esclareçamos de antemão: uma análise científica da concorrência só é possível depois de se compreender a natureza interna do capital, do mesmo modo que o movimento aparente dos corpos celestes somente é compreensível para quem conhece seu movimento real, embora imperceptível aos sentidos. Não obstante, para compreender a produção da mais-valia relativa com base apenas nos resultados já obtidos, deve-se observar o seguinte [O Capital I - I, p. 240; El Capital I-II, p. 384].

Esta antecipação é necessária, portanto, para a compreensão da produção da maisvalia relativa; seu objetivo é explicar qual interesse o capitalista individual tem na promoção do progresso técnico (a questão não é óbvia dentro da teoria de Marx uma vez que, se generalizado, o progresso técnico em um setor não beneficia significativamente seus capitalistas, pois leva à queda do valor dos produtos).

Em seguida, através de um exemplo numérico, ele introduz os conceitos de valor individual e valor social. Para isto, supõe que um capitalista que consegue duplicar a força produtiva do trabalho na produção de determinada mercadoria (sem que se alterem os valores dos meios de produção utilizados) consiga produzi-la com um valor individual de 9 pence, abaixo do valor social de 1 xelim (12 pence). Comenta então:

O verdadeiro valor de uma mercadoria, porém, não é seu valor individual, mas sim seu valor social, isto é, não se mede pelo tempo de trabalho que custa realmente ao produtor, no caso individual, mas pelo tempo de trabalho socialmente exigido para sua produção. Portanto, se o capitalista que aplica o novo método vende sua mercadoria pelo seu valor social de 1 xelim, ele a venderá 3 pence acima de seu valor individual, realizando assim uma mais-valia extra de 3 pence [O Capital I - I, p. 240; El Capital I-II, p. 385].

Portanto, o valor individual é definido como o tempo de trabalho que a mercadoria custa ao produtor; o valor social, como o tempo de trabalho socialmente necessário; e a mais-valia extra, como a diferença entre ambos.

Comentando a expressão monetária do trabalho na empresa do capitalista que conseguiu duplicar a força produtiva, Marx acrescenta:

Essa expressão monetária é maior do que a expressão monetária do trabalho social médio da mesma espécie (...). O trabalho de força produtiva excepcional atua como trabalho potenciado ou cria, no mesmo espaço de tempo, valores maiores do que o trabalho social médio da mesma espécie [O Capital I - I, p. 241; El Capital I-II, p. 386]. 
Portanto, diferentemente do que havia afirmado no Capítulo I, que o aumento da força produtiva do trabalho não leva à maior produção de valor, Marx aqui diz o contrário. Não há, contudo, nenhuma incoerência; isto se explica pela mudança do contexto teórico. No Capítulo I, Marx analisa as conseqüências de um aumento da força produtiva do trabalho socialmente necessário; no Capítulo $\mathrm{X}$, analisa os efeitos, na produção de valor, de um aumento na força produtiva do trabalho vinculado a um capital apenas (o que faz este trabalho passar a ser, portanto, mais produtivo do que a média social).

Voltaremos a esta questão na subseção 5.2.3, já que há uma controvérsia a respeito.

\section{c) No Capítulo X do Livro III}

No Capítulo X do Livro III, já no contexto teórico apropriado para analisar a concorrência entre os capitais, Marx retoma a questão da determinação do valor e da maisvalia extra. Volta a falar de valor individual, como no Capítulo X do Livro I, mas substitui o termo valor social por valor de mercado. Não parece haver nenhuma questão teórica de fundo envolvida nesta troca de nomes ${ }^{3}$. E como a redação da versão do Livro I publicada pelo próprio Marx foi posterior à do Livro III, deixado por ele na forma de rascunhos, podemos concluir que o termo afinal preferido foi o de valor social ${ }^{4}$.

No Capítulo X do Livro III, o valor individual é definido como o valor de uma mercadoria considerando apenas sua produção por um único capital, ou sua produção por um grupo de capitais com as mesmas condições de produção; corresponde, portanto, ao

\footnotetext{
${ }^{3} \mathrm{O}$ valor social introduzido no Capítulo X do Livro I corresponde, claramente, ao valor de mercado introduzido no Capítulo X do Livro III. Por outro lado, a expressão valores mercantis, que Marx usa já na p. 47 do Livro I (ou seja, ainda no primeiro capítulo: “Como cristalizações dessa substância social comum a todas elas [as mercadorias], são elas valores — valores mercantis”.) parece constituir apenas uma ênfase, e não uma diferenciação, ou um enriquecimento, do conceito de valor. Valores mercantis em alemão é Warenwerte. É a mesma expressão que reaparece depois no título do Capítulo IX do Livro III: "Formação de uma Taxa Geral de Lucro (Taxa Média de Lucro) e Transformação dos Valores Mercantis em Preços de Produção”. Estes “valores mercantis” são tradução do alemão Warenwerte. Já os “valores de mercado" do Capítulo X do Livro III que, como vimos, correspondem aos "valores sociais", são tradução do alemão Marktwerte [Das Kapital III, p. 164 e p. 182].

${ }^{4}$ Há pelo menos uma desvantagem clara do termo valor de mercado, que é a confusão com o preço de mercado.
} 
tempo de trabalho abstrato necessário à produção de uma mercadoria em condições de produção homogêneas.

O valor individual de algumas (...) mercadorias estará abaixo do valor de mercado (isto é, sua produção exige menos tempo de trabalho do que o expresso pelo valor de mercado), o de outras estará acima dele [O Capital III-IV, pp. 131-2].

Já o valor de mercado (valor social)

(...) deverá ser considerado, por um lado, como o valor médio das mercadorias produzidas numa esfera, e, por outro, como valor individual das mercadorias produzidas nas condições médias da esfera e que constituem a grande massa dos produtos da mesma. É só em conjunturas extraordinárias que as mercadorias produzidas nas piores condições, ou nas condições mais favoráveis, regulam o valor de mercado que, por sua vez, constitui o centro de oscilações dos preços de mercado ${ }^{5}$ [O Capital III-IV, p. 132].

O valor de mercado (valor social), portanto, é determinado pela quantidade de trabalho abstrato necessário para produzir a mercadoria nas condições médias de uma esfera de produção. Como Marx desenvolve longamente, estas “condições médias" não se referem a uma média aritmética, ou a uma média matemática qualquer. Dependendo das relações entre a estrutura da oferta e a demanda social, podem ser definidas tanto pelas condições de produção mais favoráveis (caso em que o valor de mercado coincide com o menor valor individual) quanto pelas menos favoráveis (caso em que o valor de mercado coincide com o maior valor individual).

É importante registrar que esta influência da demanda social na determinação do valor de mercado (social) não significa retirar da produção a determinação do valor. $\mathrm{O}$ papel da demanda social aqui é o de selecionar quais condições de produção constituem a referência para o setor. Assim, continuam a ser as condições de produção, e a partir delas o tempo de trabalho, os responsáveis pela definição da magnitude do valor ${ }^{6}$.

\footnotetext{
${ }^{5}$ Como Marx diz depois, quando se consideram os preços de produção, são estes que constituem o centro das oscilações dos preços de mercado. Ver O Capital III-IV, p. 145. E, mais adiante, esse papel passa para os preços de venda dos comerciantes. Examinaremos esta questão na seção 5.3.

${ }^{6}$ Roman Rosdolsky [2001, pp. 86-92] analisa de forma extensa esta questão.
} 
É possível dizer que a definição do valor de mercado apresentada no Capítulo X do Livro III, na verdade, apenas detalha o que já estava dito no Capítulo I do Livro I (quando a magnitude do valor foi explicada pelo trabalho socialmente necessário). Acrescenta apenas a especificação de que o tempo de trabalho socialmente necessário é determinado para uma esfera de produção, com a fixação do valor de mercado a partir de uma diversidade de valores individuais. Fazer esta distinção tornou-se importante para o tratamento da concorrência entre os capitais e, portanto, para definir a mais-valia extra e o superlucro:

(...) [A]s mercadorias cujo valor individual está abaixo do valor de mercado realizam uma mais-valia extraordinária ou um superlucro, enquanto aquelas cujo valor individual está acima do valor de mercado não podem realizar parte da mais-valia nelas contida ${ }^{7}$ [ $\mathrm{Capi}^{-}$ tal III-IV, p. 132].

Naturalmente, a mais-valia extraordinária de agora é a mesma mais-valia extra definida anteriormente. Quanto ao conceito de superlucro, aqui aparece identificado com a mais-valia extra. Contudo, Reinaldo Carcanholo certamente tem razão quando esclarece que há uma distinção de nível de abstração entre estes dois conceitos (ele usa o termo lucro extraordinário, e não superlucro):

[A] mais-valia extra, quando realmente apropriada por um capital, a partir dos preços reais de mercado, converte-se em lucro extraordinário [Carcanholo, 2000].

Esta interpretação de que o superlucro e a mais-valia extra não são a mesma coisa é confirmada por observações que Marx faz no fim do Capítulo X do Livro III: ele fala de um superlucro "em conseqüência de monopólios", e ainda de um superlucro que "pode, além disso, surgir ainda quando certas esferas da produção estão em condições de evitar a transformação dos valores de suas mercadorias em preços de produção e, por conseguinte, a redução de seus lucros ao lucro médio" [O Capital III-IV, p. 145]. Ele retoma este tema, ainda, na seção sobre a renda da terra.

Assim, a mais-valia extra se define por uma diferença (positiva) entre o valor social e o individual; o superlucro, que é simplesmente o lucro acima do lucro médio, tanto pode

\footnotetext{
${ }^{7}$ Esta frase deve ser entendida como "não podem realizar parte da mais-valia individual nelas contida".
} 
surgir da mais-valia extra quanto de preços de mercado acima dos preços de produção para as mercadorias vendidas ${ }^{8}$.

\subsection{2 - Produção de mais-valia extra a partir do trabalho de maior}

\section{força produtiva}

Como vimos na subseção anterior, à primeira vista há uma incongruência entre os textos de Marx do Capítulo I e do Capítulo X, ambos do Livro I de O Capital, citados acima. Enquanto o primeiro afirma que "o mesmo trabalho proporciona, portanto, nos mesmos espaços de tempo, sempre a mesma grandeza de valor, qualquer que seja a mudança da força produtiva" [O Capital I-I, p. 53], o segundo afirma que "o trabalho de força produtiva excepcional atua como trabalho potenciado ou cria, no mesmo espaço de tempo, valores maiores do que o trabalho social médio da mesma espécie" [O Capital I - I, p. 241].

É perfeitamente razoável, no entanto, dizer que estes dois textos não são incongruentes, embora pareçam ser, à primeira vista. Isto porque, no Capítulo I, Marx refere-se a um aumento na força produtiva do trabalho médio, que reduz o tempo de trabalho socialmente necessário. O contexto do capítulo deixa isto muito claro; e nem poderia ser de outra maneira, já que naquele momento da exposição não é possível ainda tratar da diversidade dos capitais e da concorrência. Por outro lado, o Capítulo X trata exatamente da questão da existência de "um trabalho de produtividade excepcional" (ou seja, maior do que a média social), antecipando um tema que pertence ao Livro III, ao nível de abstração dos "muitos capitais" e da concorrência. Aí Marx diz, sem ambigüidade alguma e com toda clareza, que "um trabalho de produtividade excepcional (...) cria", ele próprio, "no mesmo espaço de tempo, valores maiores do que o trabalho social médio da mesma espécie". Ou seja, a diferença entre o que se diz nestes dois capítulos deve-se à diferença dos níveis de abstração entre o Livro I e o Livro III (antecipado no Capítulo X do Livro I); este último é o adequado para tratar a questão da mais-valia extra 9 .

\footnotetext{
${ }^{8}$ Outra possibilidade, naturalmente, é que o superlucro se origine de preços de mercado dos meios de produção inferiores aos preços de produção.

${ }^{9}$ Reinaldo Carcanholo chamou a atenção para a diferença entre o que é dito nos dois capítulos, interpretandoa contudo, ao contrário do que fazemos aqui, como uma verdadeira incoerência (fala de uma "total e com-
} 
Quando levamos em conta estas diferenças nos níveis de abstração, a teoria de Marx parece perfeitamente clara. Um aumento na força produtiva média, social, do trabalho, não leva a uma maior produção de valor por unidade de tempo, mas apenas à maior produção de valores de uso; contudo, um aumento localizado, não generalizado, na força produtiva do trabalho, que faz as mercadorias produzidas por este trabalho de maior produtividade (que atua como trabalho potenciado) terem valores individuais inferiores aos valores sociais, leva à produção de mais valor por unidade de tempo e, portanto, à produção de mais-valia extra. A origem da mais-valia extra, assim, está na existência de condições de produção superiores às condições médias, que "potenciam" a capacidade do trabalho de criar valor ${ }^{10}$.

É útil, aqui, analisar em que consistem as diferenças de condições de produção que interferem na força produtiva do trabalho.

Tanto no Capítulo X do Livro I quanto no Capítulo X do Livro III de O Capital, Marx se centra nas desigualdades das condições técnicas. Já na Seção VI do Livro III, que trata da renda da terra, e que tem o sugestivo título de "Metamorfoses do Sobrelucro em Renda Fundiária", Marx se refere à diversidade das condições naturais. Uma das formas de renda, a renda diferencial, nasce justamente da maior força produtiva do trabalho a partir de condições naturais mais favoráveis - fertilidade do solo e clima, de um lado, e localização, de outro. (Se tratamos de outros tipos de produção, podemos mencionar outros tipos de condições naturais, naturalmente; assim, no caso da pesca, podemos falar da diversidade da piscosidade dos rios ou dos mares.)

Há outro tipo de condições de produção que não é mencionado explicitamente por Marx, mas que é importante também tomar em consideração: podemos chamá-las de condições institucionais. Como exemplo, podemos citar normas de proteção ao meio-am-

pleta incoerência"); ele busca resolvê-la através da demonstração de que no Capítulo X Marx se expressou de modo impreciso [Carcanholo 2000], e defendendo a explicação da origem da mais-valia extra que criticaremos na próxima subseção.

${ }^{10}$ Esta faculdade de um trabalho de maior força produtiva criar mais valor no mesmo intervalo de tempo já havia sido mencionada no Capítulo 3, subseção 3.3.3, quando foi mencionada que uma das propriedades quantitativas que influenciam a determinação quantitativa do trabalho abstrato é sua produtividade. Este é um aspecto do que chamamos então de normalização do trabalho. 
biente. Não há dúvida de que importam para a definição dos custos de produção, e portanto do tempo de trabalho socialmente necessário à produção de diversas mercadorias - cimento, por exemplo. Como veremos na última seção deste capítulo, isto abre a possibilidade para um tipo de concorrência particularmente nocivo.

Alguns autores deixam razoavelmente explícito ${ }^{11}$ que compartilham a interpretação da formação do valor de mercado e da mais-valia extra a partir da noção de que o trabalho de maior força produtiva cria, num mesmo espaço de tempo, maior valor. Sem querer comprometê-los com a argumentação desenvolvida aqui, citemos alguns deles.

Em primeiro lugar, Isaak Rubin, que no Capítulo 14 de A Teoria Marxista do Valor inclui a produtividade do trabalho como um dos critérios para a determinação da magnitude da criação de valor (cf. Capítulo 3, subseção 3.3.3) e que no Capítulo 16 diz que “(...) o valor de mercado criado é uniforme para todas as mercadorias de um dado tipo e qualidade” [Rubin 1980, p. 192]. Em segundo lugar, Moishe Postone, que diz que “(...) o incremento de produtividade resulta em incrementos de curto prazo no montante de valor gerado por unidade de tempo" [Postone 1993, p. 290]. Finalmente, Alfredo Saad-Filho, que diz que "(...) trabalhadores menos produtivos (devido a piores máquinas, qualificação ou disciplina) produzem menos valor que seus colegas no mesmo tempo" [Saad-Filho 1997, p. 467].

\subsection{3 - Uma interpretação distinta}

\section{a) Mais-valia extra a partir de transferências de valor}

Há uma interpretação do mecanismo da geração da mais-valia extra distinta da defendida acima. Segundo esta interpretação, a mais-valia extra se explicaria pela transferência de valor produzido pelos trabalhadores das empresas que têm condições de produção mais desfavoráveis para os capitalistas das empresas que têm condições mais favoráveis.

\footnotetext{
11 Razoavelmente explícito apenas porque nenhum deles escreveu a frase "a mais valia extra não é conseqüência de transferência de valor”. Sem ela, sempre é possível forçar uma interpretação diferente.
} 
Esta interpretação é defendida, por exemplo, por Ernest Mandel, em O Capitalismo Tardio $^{12}$. Contrapondo-se a três autores (Busch, Schöller e Seelow, in Weltmarkt und Weltwährungskrise, Bremen, 1971) que defendem que a mais-valia extra se explica a partir de um trabalho mais produtivo "calculado como mais intensivo" [Mandel 1985, p. 65 e p. 67], Mandel afirma que “[t]udo o que [esta interpretação] realmente faz é deslocar a criação do valor da esfera da produção para a esfera da circulação" [p. 67] $]^{13}$. Vê portanto "uma dificuldade", que acredita resolver explicando a mais-valia extra a partir de transferências de valor:

Marx encontrou uma solução positiva para esta dificuldade ao partir da proposição de que a produção de mais-valia é determinada pelo dispêndio físico, na esfera da produção, de trabalho vivo, abstrato e homogêneo - esse aspecto, pela suposição do nivelamento da intensidade do trabalho e da taxa de mais-valia. Todos os fenômenos suscitados pela concorrência de capitais e as relações da oferta e da demanda no mercado podem unicamente efetuar uma redistribuição dessa quantidade, sem aumentá-la ou diminui-la.

Quando Marx afirma que as empresas que operam com uma produtividade abaixo da média obtêm menos do que o lucro médio, e que, em última análise, isto corresponde ao fato de que desperdiçaram trabalho social, tudo o que essa formulação quer dizer é que, no mercado, as firmas que funcionam melhor se apropriam do valor ou da mais-valia realmente produzida pelos operários daquelas empresas. Não significa absolutamente que estes tenham criado menos valor ou menos mais-valia do que o indicado pelo número de horas trabalhadas. Essa é a única interpretação de $O$ Capital, volume III $^{14}$, capítulo X que pode ser harmonizada com o texto como um todo e com o espírito da teoria do valor de Marx; e tal interpretação manifestamente simplifica o conceito de transferência de valor [Mandel 1985, pp.68-9].

12 Outros autores que defendem esta interpretação incluem: Pierre Salama [1975, p. 238]; Jacques Valier [1982, t. 1, p. 225]; Makoto Itoh e Nobuharu Yokokawa [1979, pp. 107-113]; Makoto Itoh [1988, pp. 226235, especialmente pp. 234-5, e p. 144-5]; Øyvind Horverak [1988, p. 283-4, e exemplo pp. 290-7]; Guglielmo Carchedi [1991, Cap. 3, seção 3.2; e também pp. 263-4]; Reinaldo Carcanholo [2002].

${ }^{13}$ Como não foi possível consultar o texto de Busch, Schöller e Seelow, não há condições aqui de avaliar se a crítica de Mandel é correta. Mas é possível afirmar que a interpretação defendida nesta tese, que ao que parece se aproxima (ou se identifica) com a dos três autores, não desloca a criação do valor para a esfera da circulação, como vimos nas duas subseções anteriores e na subseção 3.3.3 do Capítulo 3.

\footnotetext{
${ }^{14}$ Naturalmente, Mandel se refere aqui ao que nas edições brasileiras é chamado de Livro III.
} 
Há diversos problemas nestes parágrafos. Em primeiro lugar, ao falar em dispêndio físico de "trabalho vivo, abstrato e homogêneo", Mandel parece desconsiderar o processo de normalização do trabalho, de contagem social de seu tempo de duração. Como vimos na subseção 3.3.3, esta contagem social leva em conta não apenas o tempo de duração do trabalho, mas também sua intensidade e sua produtividade, além da sua qualificação. Mandel já havia sugerido uma interpretação excessivamente física da quantidade de horas trabalhadas que define a magnitude do trabalho abstrato ${ }^{15}$ algumas linhas antes, quando afirmou que:

A teoria marxista do valor parte do axioma de que a massa total de mais-valia é igual à massa total de trabalho social excedente, ou, em outras palavras, que a massa total de maisvalia é determinada pela diferença entre o número total de homens-hora de trabalho e o montante total de trabalho necessário (o número de horas de trabalho necessárias para produzir o equivalente da soma total dos salários dos operários produtivos) [Mandel 1985, p. $68]$.

Em segundo lugar, ao dizer que as firmas que funcionam melhor se apropriam de uma parte do valor produzido pelas firmas que têm produtividade abaixo da média, Mandel faz uma interpretação de Marx que não se apóia em nenhuma frase que lhe dê base. Em nenhum momento a idéia de transferência de valor aparece nos textos de Marx neste contexto; além disso, se as firmas menos produtivas transferissem valor, não seria possível dizer que desperdiçam trabalho social; elas apenas não se beneficiariam deste trabalho, mas outras firmas o fariam. Não haveria, do ponto de vista social, nenhum desperdício!

\section{b) Valores de uso iguais, valores diferentes?}

Mas o argumento mais importante contra a interpretação da mais-valia extra como decorrente de transferências de valor é que ela implica que mercadorias iguais têm no momento da produção valores diferentes. As mercadorias produzidas pelas empresas de piores condições, custando mais horas de trabalho, representariam maior produção de valor, e as produzidas em melhores condições, custando menos horas, representariam menor produção

\footnotetext{
${ }^{15}$ Ou seja, sugere que o tempo de trabalho socialmente necessário é o tempo físico de trabalho, e não o tempo abstrato, socialmente igualado.
} 
de valor. Estes valores diferentes seriam igualados por uma transferência de valor no momento da circulação.

Ou seja, mercadorias que têm idêntico valor de uso objetivariam quantidades distintas de trabalho abstrato, embora na venda realizem o mesmo quantum de valor. Ora, esta concepção vai contra toda a lógica da formação do trabalho abstrato, explicitada por Marx nos dois primeiros capítulos do Livro I de $O$ Capital, e que analisamos nos Capítulos 1 e 3 deste trabalho. Como vimos na subseção 3.3.2 do Capítulo 3, não existe nenhum mecanismo que "conta" o trabalho abstrato de forma independente do processo de troca; é a partir da igualação dos produtos do trabalho que se faz a igualação dos trabalhos. Não faz sentido dizer que, para Marx, valores de uso iguais podem representar quantidades de trabalho abstrato objetivado, isto é, valores, diferentes.

Reinaldo Carcanholo, que provavelmente é o autor, desde Mandel, que desenvolveu mais a argumentação de que a mais-valia extra resulta de transferências de valor, percebe esta dificuldade, embora a partir de um raciocínio diferente do exposto acima (parte da dificuldade em explicar a mais-valia extra pela apropriação: já que se a mercadoria é vendida por um preço inferior ao seu valor de mercado, o capitalista não se apropria de toda a mais-valia extra que teria sido transferida). Diz o seguinte:

Para dar conta da existência da mais-valia extra que, em essência, consiste em uma forma particular da mais-valia, e não podendo apelar para os conceitos de produção ou apropriação, não temos outra alternativa que apelar para um conceito diferente e que não aparece no texto de Marx: o conceito de geração.

Assim, a mais-valia extra é gerada na empresa inovadora, com magnitude determinada. Pode ou não ser apropriada inteiramente sob a forma de lucro extraordinário. Caso não seja inteiramente apropriada é porque o diferencial de valor foi transferido para outro setor da economia, graças ao fato de que o preço da mercadoria foi menor do que o correspondente ao valor. A mais-valia extra não foi produzida pelo trabalho de produtividade excepcional, pois ele produz valor em quantidade igual ao trabalho normal; ela é produzida pelo trabalho das empresas não inovadoras que se vêem obrigadas a transferir à inovadora (ou, em parte, a outros setores), graças à existência de um único preço de mercado para a mercadoria [Carcanholo 2000].

A idéia de que empresas que produzem quantidades diferentes dos mesmos valores de uso produzem quantidades iguais de valor, mas geram quantidades distintas de valor, contudo, é demasiado artificial para poder resolver as dificuldades encontradas. 


\section{c) $O$ valor de mercado é obrigatoriamente igual à média aritmética (ponde-}

rada) dos valores individuais?

Há ainda outros problemas importantes na interpretação da mais-valia extra como transferência de valor.

Uma delas é a possibilidade, mencionada por Marx, de que o valor social (de mercado) possa corresponder a um dos extremos dos valores individuais. Ela deixa clara a impossibilidade de explicar a mais-valia extra como transferência de valor.

Suponhamos que uma ou algumas empresas introduzem uma tecnologia inovadora que permite produzir com menores gastos de trabalho, e admitamos que (pelo menos inicialmente) o valor de mercado não se altere. Esta ou estas empresas ganham então maisvalia extra, sem que nenhuma outra perca mais-valia nenhuma. Do mesmo modo, se algumas empresas retardatárias mantém uma tecnologia ultrapassada, e o valor de mercado é fixado com base nas condições técnicas das demais empresas, que têm os valores individuais mais baixos, as empresas ultrapassadas não realizarão parte da sua mais-valia, sem que nenhuma outra ganhe nada com isto. Fica claro que aqui não é possível falar de transferência de mais-valia. O caso é claramente de produção de valor, maior ou menor de acordo com a relação entre a produtividade do trabalho em uma empresa e a produtividade das empresas que determinam o valor social.

Apenas no caso da fixação do valor de mercado na média aritmética seria possível dizer que as empresas menos eficientes perdem o que as mais eficientes ganham - mas este não é, manifestamente, o único caso que deve ser considerado.

Um dos autores que defendem esta interpretação da mais-valia extra, Guglielmo Carchedi, dá razão involuntariamente a este argumento.

Carchedi teoriza que o valor de mercado é sempre definido pelos capitais que usam a tecnologia modal (isto é, dominante quantitativamente - este é, como vimos, um dos casos considerados por Marx, quando fala nas mercadorias que "constituem a grande massa dos produtos da mesma”). Dá um exemplo [Carchedi 1991, pp. 65-6] com três capitais, que têm tecnologias de produção e composições orgânicas diferentes, e que produzem quantidades diferentes do mesmo produto. $\mathrm{O}$ valor individual da unidade de produto é diferente; Carchedi seleciona então um deles como correspondendo ao caso modal, e o toma como base para a definição do valor social (de mercado). No entanto, quando faz o 
cálculo de quanto seria o valor social total tendencialmente realizado, encontra um número diferente do que corresponde à soma dos valores individuais (o primeiro seria de 384 , contra 360 da soma dos valores individuais), o que inviabilizaria falar em transferência de valor. Aplica então uma "razão de distribuição" (distributional ratio) para reduzir proporcionalmente os valores de mercado (sociais) e igualar sua soma com a dos valores individuais. Com isto, as próprias mercadorias das empresas supostamente "modais", que serviriam de base para todo o cálculo, passam a ter um valor de mercado inferior a seu valor individual, e transfeririam valor para as empresas mais produtivas que elas.

Carchedi parece não perceber que com este procedimento não há sentido algum em falar em determinação do valor de mercado pela tecnologia modal, e que de fato ele determina o valor de mercado como uma média aritmética ponderada dos valores individuais. Mas foi obrigado a adotá-lo para manter a coerência da idéia da transferência de valor.

\section{d) Qual é o valor propriamente dito?}

$\mathrm{Na}$ verdade, toda esta interpretação da mais-valia extra como transferência de valor tende a confundir valor e preço. Transferências de valor na circulação, para Marx, decorrem sempre de diferenças entre valor e preço: se uma venda é feita por um preço diferente do valor, o vendedor ganha o que o comprador perde. Já as diferenças entre o valor individual e o valor social dizem respeito a outra questão, que é a da formação do valor social a partir dos valores individuais, no processo de produção.

Tratar o valor de mercado (valor social) como resultado de uma transferência de valor equivale a transformá-lo numa espécie de preço de produção. Carchedi, aliás, faz isto explicitamente; para ele, valor de mercado e preço de produção são dois casos do valor social:

$\mathrm{O}$ valor de mercado e o preço de produção correspondem a duas situações diferentes. Se não assumimos a mobilidade do capital entre ramos, todas as mercadorias em um ramo tendencialmente realizam o mesmo valor de mercado por unidade de produto, de tal maneira que capitais com diferentes níveis de eficiência (e portanto de composições orgânicas dos capitais) tendencialmente realizam taxas de lucro diferentes.

Se assumimos a mobilidade do capital entre ramos, o valor social é dado pela igualação da taxa de lucro. Enquanto o capital não for suficientemente móvel, o valor social é dado pelo valor de mercado. Mas, tão logo possa ser observado que ramos constantemente ultrapassam uns aos outros em termos de lucratividade, podemos assumir que o capital tornou-se 
suficientemente móvel para justificar uma igualação tendencial das taxas de lucro. Neste caso, o valor social é o preço de produção. No primeiro caso, os valores individuais são transformados em valores de mercado. No último caso, eles (e não os valores de mercado!) são transformados em preços de produção [Carchedi 1991, p. 73].

O valor individual funciona como o valor propriamente dito, e o valor de mercado se torna uma variante do preço de produção. Outro autor que defende a mesma concepção de mais-valia extra, Makoto Itoh, vai um pouco mais longe, e propõe explicitamente abandonar a noção de valor de mercado em favor da noção de preço de produção de mercado ${ }^{16}$ [Itoh 1988, pp. 233-4].

Posições como a destes dois autores, que são coerentes com a interpretação que defendem, deixam claro que, para eles, o "verdadeiro valor", por assim dizer, é o valor individual. Esta é uma alteração fundamental na teoria de Marx. Tanto o contexto quanto os textos dos capítulos relevantes de $O$ Capital deixam claro que o conceito que corresponde ao valor propriamente, o valor do Capítulo I Livro I, é o de valor social (ou de mercado), e não o de valor individual.

A seguinte citação do Capítulo X do Livro I é muito clara:

O verdadeiro valor ${ }^{17}$ de uma mercadoria, porém, não é seu valor individual, mas sim seu valor social, isto é, não se mede pelo tempo de trabalho que custa realmente ao produtor, no caso individual, mas pelo tempo de trabalho socialmente exigido para sua produção [Capital I - I, p. 240; El Capital I-I, p. 385].

Esta passagem, na verdade, é muito próxima à que explicita a determinação do valor pelo tempo de trabalho socialmente necessário, feita no Capítulo I:

É, portanto, apenas o quantum de trabalho socialmente necessário ou o tempo de trabalho socialmente necessário para a produção de um valor de uso o que determina a grandeza de seu valor. (...) Mercadorias que contém as mesmas quantidades de trabalho ou que podem ser produzidas no mesmo tempo de trabalho têm, portanto, a mesma grandeza de valor [Capital I, p. 48; El Capital I-I, pp. 48-9].

\footnotetext{
${ }^{16}$ Para Marx , como veremos na seção seguinte, estes dois conceitos são distintos.

${ }^{17}$ A edição Siglo Veintiuno Editores fala "valor real".
} 
Mais uma vez, fica claro que o Capítulo X prolonga, de forma bastante natural, as idéias do Capítulo I. Por outro lado, a interpretação da mais-valia extra como transferência de valor exigiria a caracterização de que "o verdadeiro valor" é o valor individual, ou seja, de que quando Marx fala de valor no Capítulo I, está se referindo ao que depois chamará de valor individual. Isto implicaria dizer que, para Marx, a determinação do valor pelo trabalho socialmente necessário refere-se já ao valor individual. Mas, se o valor individual pode ser o valor dos produtos de um único capital, como seria possível dizer que o trabalho que foi gasto neles é o "socialmente necessário"?

Em resumo: o valor individual não é o valor propriamente, é apenas um passo na formação do valor social. A diferença entre os dois, portanto, diz respeito à formação do valor no processo de produção, nas condições concretas em que diversos capitais concorrem, tendo condições de produção diferentes. Não deve ser confundida com uma diferença do preço em relação ao valor, que diz respeito a uma transferência de um valor criado anteriormente, realizada no momento da venda, isto é, da circulação; este será o tema da próxima seção.

\subsection{4 - Concorrência intra-setorial e progresso técnico}

Com os conceitos de valor individual, valor de mercado, mais-valia extra e superlucro, Marx chama a atenção para um aspecto da concorrência entre os capitais que costuma ser negligenciado, o da concorrência intra-setorial. A concorrência intersetorial, isto é, a mobilidade dos capitais que procuram os setores que têm maior taxa de lucro, dá origem a uma tendência à igualação das taxas de lucro, à formação de uma taxa geral de lucro, e conseqüentemente à formação dos preços de produção. Já concorrência intra-setorial questiona permanentemente esta igualação entre as taxas de lucro, desiguala estas taxas dentro de um mesmo setor; a ênfase neste aspecto desigualador da concorrência é uma característica fundamental da abordagem marxista.

O funcionamento da concorrência intra-setorial é um dos desdobramentos centrais da interação contraditória entre trabalho concreto e trabalho abstrato de que já tratamos no Capítulo 3, subseção 3.2.4. Consideramos aqui sua relação com o progresso técnico e com seus efeitos; outros aspectos deste tipo de concorrência serão deixados para a última seção deste capítulo. 
A concorrência intra-setorial explica porque as empresas são levadas a uma busca permanente de progresso técnico: só podem obter ganhos extraordinários quando têm uma vantagem relativa em relação às concorrentes. A produção de mais valores de uso não interessa em si mesma, mas apenas na medida em que permite produzir mais valor no mesmo espaço de tempo. Em um quadro concorrencial, os ganhos extraordinários obtidos a partir de inovações técnicas serão sempre provisórios: tão logo as novas tecnologias se generalizem, o valor social das mercadorias produzidas cairá, e a taxa de lucro voltará ao nível anterior ${ }^{18}$. Por outro lado, qualquer empresa que não introduza novas tecnologias redutoras do custo de produção ${ }^{19}$ não manterá suas posições, mas retrocederá. Podemos representar a busca de mais-valia extra a partir de progresso técnico pelas empresas como uma corrida dos representantes destas empresas sobre um esteira rolante que rola em sentido contrário, e com uma velocidade cujo módulo é dado pela "média social" da velocidade da introdução de progresso técnico. Se os corredores forem mais rápidos, a esteira também rolará mais depressa no sentido contrário, e eles não terão portanto qualquer vantagem. Como a esteira não pode ser parada, não haverá nunca um ganhador final, e nenhum competidor poderá parar, sob pena de ficar irremediavelmente para trás.

Moishe Postone compreendeu bem o sentido desta dinâmica de redefinição do tempo de trabalho socialmente necessário:

Examinando as determinações mais abstratas da dinâmica da sociedade capitalista em termos da interação destas duas dimensões, vimos como cada novo nível de produtividade tanto determina a hora de trabalho social quanto, por sua vez, é redeterminado pela estrutura temporal abstrata como nível básico de produtividade. Mudanças no tempo concreto efetuadas pelos incrementos de produtividade são mediadas pela totalidade social de uma maneira que as transforma em novas normas de tempo abstrato (tempo de trabalho socialmente necessário) que, por sua vez, redeterminam a hora de trabalho social constante [Postone 1993, p. 299].

\footnotetext{
${ }^{18} \mathrm{Na}$ verdade, se levarmos em conta a elevação da composição orgânica do capital e a lei da tendência decrescente da taxa de lucro, a taxa de lucro poderá cair abaixo do nível anterior. Esta questão, no entanto, ultrapassa os limites desta tese.

${ }^{19} \mathrm{Ou}$ dos custos de distribuição. Como veremos na próxima seção, a taxa de lucro geral é definida, de fato, como a razão entre a massa de mais-valia (de que se subtraem os custos improdutivos) e a massa dos capitais industriais e comerciais. Os custos de distribuição, naturalmente, são custos improdutivos.
} 
Como veremos na seção 5.4, Postone prefere uma imagem diferente da esteira rolante, a do "moinho de pisar".

\subsection{5 — A “difusão solidária” do aumento da produtividade do trabalho}

Há uma conseqüência deste processo de interação entre o tempo de trabalho concreto e o tempo de trabalho abstrato que, pela sua importância, deve ser enfatizada aqui: o impacto do progresso técnico realizado em alguns setores é generalizado.

Quando o progresso técnico se generaliza em um setor — digamos, no setor A -, reduz o valor das mercadorias produzidas aí; isto significa a ampliação do "poder de compra real" do trabalho realizado em todos os outros. Isto é, nos outros setores, supondo que não tenha havido nenhuma mudança nas suas condições de produção, a mesma quantidade de trabalho se objetiva no mesmo valor, e troca-se por mais mercadorias do setor A. Quando o progresso técnico atinge o setor de meios de consumo, e se generaliza aí, reduz o seu valor. $O$ trabalho realizado pelos trabalhadores de setores que não se modificaram tecnicamente também tem seu poder de compra real ampliado. Isto abre a possibilidade de redução do valor da força de trabalho de todos os trabalhadores (trata-se, como é bem conhecido, da produção de mais-valia relativa), mas também de um aumento dos salários reais, inclusive dos trabalhadores que não experimentaram nenhum aumento de sua produtividade fisica.

Em geral, o ritmo do progresso técnico é diferenciado na economia; há setores em que ele é muito rápido, outros em que ele é muito mais lento ${ }^{20}$. Ora, o progresso técnico, quando generalizado em cada setor, amplia de modo igual o poder de compra da hora de trabalho de todos os setores, sejam estes caracterizados pela rapidez ou pela lentidão do aumento da força produtiva física do trabalho. Há uma espécie de "difusão solidária do aumento da produtividade do trabalho", que se expressa na produção de mais-valia rela-

\footnotetext{
${ }^{20}$ Como exemplo deste último caso, temos muitos dos setores chamados de "serviços". Muitos deles não são produtivos, mas esta questão não tem importância neste contexto: o progresso técnico que reduz custos improdutivos é tão importante quanto o que amplia a capacidade de produzir valores de uso.
} 
tiva no conjunto da economia (se este processo levar à redução do valor da força de traba1ho) ou na elevação de conjunto dos salários reais ${ }^{21}$.

Com relação à determinação dos salários reais, Luigi Pasinetti, em sua obra Structural Change and Economic Growth, faz uma formulação essencialmente semelhante, embora no contexto de um quadro teórico distinto do que está sendo exposto neste trabalho, e a contrasta com a concepção neoclássica. Enfatiza o caráter macroeconômico dos salários (pois "dependem da produtividade física do sistema econômico como um todo") [Pasinetti 1981, pp. 136-8]. Voltaremos a esta questão no Capítulo 6, do quadro da contraposição da economia marxista com outras abordagens.

Compreender a existência da "difusão solidária do aumento da produtividade do trabalho" é fundamental para o entendimento das diferenças no funcionamento da lei do valor do plano nacional e no plano internacional, como veremos na seção 5.5.

\subsection{6 - A reavaliação dos estoques}

Outro aspecto da interação contraditória do trabalho concreto e do trabalho abstrato tem grande importância, e deve ser mencionado, ainda que brevemente.

Uma vez que a determinação da magnitude do valor inclui um processo de sincronização do tempo de trabalho contido nas mercadorias produzidas anteriormente, como vimos na subseção 3.3.5 do Capítulo 3, toda difusão de progresso técnico implica uma reavaliação dos estoques existentes das mercadorias cuja produção é afetada, de modo direto ou indireto.

Isto é especialmente importante para os estoques de capital, isto é, de mercadorias que funcionam como meios de produção (podem sofrer o que Marx chamava de obsolescência moral). Ou seja: a difusão do progresso técnico pode provocar um empobrecimento de setores retardatários tecnicamente; este empobrecimento é agravado por não se referir apenas à capacidade presente de produção, isto é, por incluir a perda de riqueza já acumulada. Como veremos na seção 5.5, este problema é especialmente relevante no plano internacional.

\footnotetext{
${ }^{21}$ Como se vê, trata-se de uma "solidariedade intersetorial”, e não obrigatoriamente da solidariedade entre os trabalhadores.
} 


\section{3 - PREÇOS E TRANSFERÊNCIAS DE VALOR NA CIRCULAÇÃO}

\subsection{1 - Uma teoria dos preços complexa}

A diferenciação entre valores e preços não se reduz, na teoria de Marx, à distinção entre valores e preços de produção e às flutuações dos preços de mercado. Vimos, na seção anterior, diferenciações no próprio conceito de valor. Além disto, a partir da Seção III do Livro III, Marx introduz mais determinações relativas aos preços, tornando esta teoria consideravelmente mais complexa: trata da distinção entre "preço-valor", preço de produção e preço de mercado, e da distinção entre "preços de produção no sentido estrito" e "preços de venda dos comerciantes". Além disto, embora não trabalhe explicitamente o tema da formação de preços de monopólio, menciona sua existência, e lhes dá um sentido teórico muito claro.

A questão da diferenciação dos preços em relação ao valor (ao preço-valor, como agora é explicitado) se vincula ao tema das transferências de valor na circulação.

Nas quatro subseções seguintes abordaremos a teoria dos preços de Marx, do Livro I de $O$ Capital à sua complexização no Livro III; na última subseção, trataremos da natureza distinta das diferenças entre, de um lado, valores individuais e valor social e entre, de outro, preços e valores.

\subsection{2 - No Livro I de O Capital: preços e desvios dos preços em relação} ao valor

Como vimos no primeiro capítulo desta tese, Marx define o preço (ou a forma preço) de uma mercadoria a partir da forma de dinheiro do valor, desde o Capítulo I do Livro I de $O$ Capital, e retoma esta questão em seguida, no Capítulo III. O preço é o valor expresso em dinheiro, é o quantum da substância do valor — o trabalho abstrato - medido a partir da quantidade de trabalho representada pelo dinheiro, e não da quantidade de trabalho que a própria mercadoria custou. O preço é, portanto, um valor de troca específico - o único que importa na economia capitalista, já que esta não é uma economia de escambo.

No Capítulo III do Livro I, Marx faz a observação de que, embora o preço seja uma categoria derivada do valor, ele tem uma certa autonomia. O preço expressa o valor como 
algo diferente dele próprio, e entre ambos pode haver, portanto, incongruências. Pode haver uma incongruência quantitativa do preço em relação ao valor, isto é, um desvio; além disto, bens que não são mercadorias podem funcionar como tais, e adquirir um preço, o que representa uma “contradição qualitativa” [O Capital I-I, p. 91; El Capital I-I, p. 125] $]^{22}$.

Se uma mercadoria é alienada por um preço distinto do seu valor, é feita uma transferência de valor entre o comprador e o vendedor. Nesse caso, ocorre o que se pode chamar de troca desigual, isto é, troca combinada com transferência de valor na circulação.

\subsection{3 — Nos Capítulo IX e X do Livro III}

No Capítulo IX do Livro III Marx define os preços de produção, como vimos no Capítulo 4; não é necessário retomar esta questão aqui.

No Capítulo X do Livro III, é desdobrado o conceito de valor, como vimos na seção anterior. Além disto, é desdobrado o conceito de preço em preço-valor, preço de produção (já definido por Marx no Capítulo IX, como vimos) e preço de mercado ${ }^{23}$.

O preço-valor é definido por Marx como o preço verificado

(...) quando as mercadorias são intercambiadas mutuamente em proporção ao valor nelas contido [O Capital III-IV, Capítulo X, p. 129].

O preço-valor é, portanto, o preço que expressa diretamente o valor, ou seja, é um preço que não se desvia do valor ${ }^{24}$. É o próprio valor, expresso em dinheiro ${ }^{25}$.

No fim do Capítulo X, Marx acrescenta o seguinte sobre o preço de produção:

\footnotetext{
22 Já tratamos desta questão na subseção 1.3.1 do Capítulo 1, onde citamos mais extensamente o texto de Marx, e na subseção 3.3.6 do Capitulo 3.

${ }^{23}$ Embora os preços de mercado sejam sugeridos desde o início de O Capital, quando Marx fala dos desvios dos preços em relação aos valores, só são explicitamente tratados no Capítulo X do Livro III.

24 Anwar Shaikh cunhou a expressão preço direto (direct price) [Shaikh, 1977] para designar o mesmo conceito. David Yaffe e Michel de Vroey falam em preço simples, Reinaldo Carcanholo em preço correspondente ao valor [Carcanholo, 1991, p. 188].

${ }^{25}$ É interessante notar que Marx, em geral, quando fala do valor, refere-se ao valor expresso em dinheiro, ou seja, ao preço-valor; mas diz simplesmente valor, não usa o termo preço-valor.
} 
O preço de produção inclui o lucro médio. Nós o denominamos preço de produção; na realidade, é o mesmo que Adam Smith chama de natural price, Ricardo de price of production, cost of production e os fisiocratas, prix nécessaire - mas nenhum deles desenvolveu a diferença entre preço de produção e valor —, porque a longo prazo ele é a condição da oferta, da reprodução da mercadoria de cada esfera particular da produção $[O$ Capital III-IV, p. 144-5].

Os preços de mercado são os preços verificados empiricamente, que flutuam em torno do preço de produção. Os desvios dos preços de mercado em relação aos valores expressam sempre uma transferência de valor no momento da venda (ou seja, da circulação). Estes desvios podem ser permanentes, quando há algum tipo de monopólio ou quando, como ocorre na agricultura, é possível obstaculizar a redução dos valores aos preços de produção. Ou podem ser transitórios, e sua importância não é menor por isto. Uma das maneiras pelas quais os capitais que concorrem podem conseguir ganhos extraordinários é esta, obtendo valor extra na circulação a partir de desvios dos preços de mercado com relação aos preços de produção.

Há ainda um outro conceito que Marx menciona um tanto de passagem no Capítulo $\mathrm{X}$, sem chegar a defini-lo: o do preço de produção de mercado. Ele é retomado na Seção VI do Livro III, no tratamento da renda da terra. O preço de produção de mercado, que Marx chama também de preço social geral, de preço geral de produção e de preço de produção regulador do mercado, corresponde, ao lado do preço individual de produção, a um desdobramento do conceito de preço de produção análogo ao realizado com o conceito de valor, e derivado deste.

Assim, ao valor individual corresponde um preço de custo individual, e ao valor de mercado um preço de custo de mercado. O preço individual de produção é o preço de custo individual + o lucro médio; o preço de produção de mercado é o preço de custo de mercado + o lucro médio. Assim, o superlucro ${ }^{26}$ é definido como:

(...) igual ao excedente do preço geral de produção da mercadoria sobre seu preço individual de produção. Os dois limites reguladores desse excedente são, por um lado, o preço

\footnotetext{
${ }^{26} \mathrm{Na}$ tradução brasileira que está sendo utilizada, aparece nesta seção o termo sobrelucro, e não mais superlucro. Trata-se, contudo, de uma variação devida aos tradutores: em alemão o termo de Marx é o mesmo, Surplusprofit [Das Kapital, Dritter Band].
} 
individual de custo, por conseguinte o preço individual de produção, e, por outro, o preço geral de produção [O Capital III-V, p. 130].

Como se sabe, o conceito de superlucro ou sobrelucro é básico na explicação da renda da terra.

\subsection{4 - No Capítulo XVII do Livro III}

No Capítulo XVII do Livro III, Marx redefine o conceito de preço de produção e introduz o de preço de venda (ou de preço de venda do comerciante):

$\mathrm{Na}$ formação da taxa geral de lucro, o capital comercial entra de modo determinante pro rata da parte que ele constitui do capital global. (...) Com isto surge (...) uma determinação mais precisa e mais restritiva do preço de produção. Por preço de produção deve entender-se, depois como antes, o preço da mercadoria = seus custos (o valor do capital constante + capital variável, nela contidos) + o lucro médio sobre eles. Mas este lucro médio é agora determinado de outro modo. É determinado pelo lucro global que este capital produtivo gera; mas não é calculado sobre esse capital produtivo total (...), mas calculado sobre o capital produtivo total + capital comercial. (...) Na taxa média de lucro já está calculada a parte do lucro global que cabe ao capital comercial. O valor real ou preço de produção do capital-mercadoria global é portanto $=c+l+h$ (em que $h$ é o lucro comercial). O preço de produção ou o preço pelo qual o capitalista industrial vende enquanto tal é, portanto, menor do que o preço de produção real da mercadoria; ou, se considerarmos a totalidade das mercadorias, estão os preços pelos quais a classe dos capitalistas industriais as vende são menores do que seus valores ${ }^{27}$. (...) Queremos conservar a expressão 'preço de produção' no sentido mais preciso acima desenvolvido. Então fica claro que o lucro do capitalista industrial é igual ao excedente do preço de produção da mercadoria sobre seu preço de custo e que, em contraste com esse lucro industrial, o lucro comercial é igual ao excedente do preço de venda [grifo JM] sobre o preço de produção da mercadoria, que é o seu preço de compra para o comerciante; que, porém, o preço real da mercadoria é = seu preço de produção + o lucro mercantil (comercial). Assim como o capital comercial só realiza lucro que já está contido no valor da mercadoria como mais-valia, assim o capital comercial apenas o realiza porque toda a mais-valia ou todo o lucro ainda não está realizado no preço da mercadoria realizado pelo capitalista industrial. O preço de venda do comerciante [grifo JM]

\footnotetext{
${ }^{27}$ Naturalmente, se a identidade soma dos valores = soma dos preços de produção deixa de existir, é por ser substituída pela identidade soma dos valores = soma dos preços de venda dos comerciantes.
} 
está, assim, acima do preço de compra não porque aquele esteja acima, mas porque este está abaixo do valor total. [O Capital III-IV, p. 205].

Podemos considerar o preço de produção redefinido (que é, podemos dizer, um preço com desconto) e o preço de venda do comerciante como desdobramentos do preço de produção. Uma decorrência desta nova conceituação, que Marx não explicita, é que os preços de mercado para os consumidores oscilam de fato em torno dos preços de venda dos comerciantes, e não em torno dos preços de produção redefinidos. É possível assim fazer um novo desdobramento de conceitos, e falar de dois tipos de preços de mercado: os preços de mercado que oscilam em torno aos preços de produção, que seriam então os preços de mercado dos capitalistas produtivos, ou seja, preços de mercado no atacado ${ }^{28}$, e os preços de mercado para os consumidores. Marx não trata desta questão; contudo, não parece que possa dar origem a nenhuma dificuldade teórica importante.

Por outro lado, nesta definição do preço de venda, Marx havia considerado que todo o capital adiantado pelo comerciante destinava-se a comprar as mercadorias que depois seriam vendidas. Mas é claro que o comerciante tem também de adiantar capital para pagar salários e para adquirir e manter instalações, etc. Na seqüência do capítulo Marx leva estas complicações em conta $^{29}$. Mas não trata de outras questões que também deveriam ser consideradas, como a dos custos de circulação do capital produtivo ${ }^{30}$.

É útil enfatizar que todo o funcionamento da esfera comercial explica-se, para Marx, por transferências de valor realizadas no momento em que os produtores vendem as mercadorias para os comerciantes com um desconto. Por outro lado, a esfera financeira funciona com base em outro tipo de transferência de mais-valia, o pagamento de juros, que não será examinado neste trabalho.

\footnotetext{
${ }^{28}$ Podemos ainda, naturalmente, distinguir o preço de compra do atacadista, igual ao preço de mercado dos capitalistas produtivos, do preço de venda do atacadista, supondo que o atacadista que compra dos produtores funciona como intermediário entre estes e os varejistas.

${ }^{29} \mathrm{O}$ tratamento que Marx lhes dá, contudo, não é inteiramente satisfatório.

${ }^{30}$ Isto é: seria preciso levar em conta, além dos custos do capital comercial (que são em geral improdutivos — só são produtivos os custos que se referem a prolongamentos do processo de produção, como os custos de conservação de estoques necessários), os custos improdutivos do capital produtivo.
} 
Por brevidade, chamaremos a partir daqui o preço de venda do comerciante de preço comercial.

\subsection{5 - Desdobramentos ulteriores do conceito de preço}

A questão da renda da terra, por sua vez, também se liga à formação dos preços de produção, já que a existência de uma renda fundiária absoluta significa a retirada de parte da mais-valia produzida pelo trabalho agrícola da equiparação da mais-valia ao lucro médio, e portanto a venda dos produtos agrícolas por um preço superior ao seu preço de produção - o que, na prática, significa que o preço do conjunto das mercadorias não-agrícolas ficará abaixo do seu preço de produção, ou do que seria seu preço de produção se os capitais pudessem ingressar livremente na produção agrícola.

E, se Marx tivesse prolongado sua análise até a inclusão do Estado (e, conseqüentemente, da tributação) e das relações com o exterior (tratando por exemplo dos royalties), novos desdobramentos dos preços de produção teriam de ser acrescentados.

\subsection{6 - Desigualdades diferentes}

Do exame das questões tratadas nesta seção e na anterior, fica claro que, para a economia marxista, há duas situações de desigualdade que são teórica e praticamente distintas: diferenças entre valores individuais e valores sociais (ou valores de mercado), e diferenças entre preços e valores ${ }^{31}$. Estas implicam transferências de valor na circulação; aquelas, decorrentes sobretudo de desigualdades tecnológicas, dizem respeito a diferenciações na própria produção de valor. Estas diferenciações implicam também reavaliações de estoques de mercadorias, especialmente do capital fixo, e portanto uma desigualdade adicional - perdas de capital, no caso da existência de equipamentos que se tornaram tecnicamente atrasados.

As diferenças entre valores individuais e valores sociais levam a intercâmbio desigual de quantidades de trabalho concreto (quando um trabalho de força produtiva superior

\footnotetext{
${ }^{31}$ Que também podem ser chamados de preços-valores; por simplicidade, falaremos sempre simplesmente em valores, seguindo nisto ao próprio Marx.
} 
à média é contado como maior quantidade de trabalho); as diferenças entre preços e valores implicam intercâmbio desigual de valor, isto é, de trabalho abstrato.

O intercâmbio desigual de valor decorre de desvios entre preços e valores; quem perde, perde porque perdeu ao vender seus produtos ou ao comprar produtos alheios, ou porque perdeu mais (por um desvio do preço maior) quando vendeu do que ganhou quando comprou. Já no caso da mais-valia extra, quem perde, isto é, quem não consegue realizar todo o valor que produziu individualmente, perde porque o trabalho que produz seus produtos é menos produtivo que o trabalho médio na sociedade e, portanto, produz socialmente menos valor no mesmo espaço de tempo. A perda no caso do intercâmbio desigual de valor é uma perda na circulação, ou seja, no processo de intercâmbio. A perda no caso da mais-valia extra é uma perda na produção, isto é, decorrente de condições de produção inferiores à média social; não há perda no processo de intercâmbio, este apenas sanciona a perda já sofrida. A mesma diferença existe, naturalmente, para os ganhos nos dois casos.

Esta questão pode ser melhor entendida a partir da caracterização do trabalho abstrato como uma substância social. Diferenças entre valores individuais e valores sociais dizem respeito à diferenciação na capacidade de produzir esta substância social; diferenças entre preços e valores dizem respeito à apropriação diferenciada desta substância social na circulação.

Ambas têm uma importância fundamental na explicação das desigualdades regionais e internacionais das economias capitalistas, como veremos na seção 5.5.

\section{4 - EM QUE CONSISTE A LEI DO VALOR?}

\subsection{1 — As três dimensões da lei do valor}

Embora a existência da lei do valor seja uma das idéias centrais da economia marxista, não há, em geral, clareza sobre qual é o seu significado. Esta seção examina o funcionamento desta lei no plano nacional, e busca mostrar que ela deve ser entendida a partir de três versões sucessivas, tornando-se, a cada uma, progressivamente mais complexa.

A seção 5.4.2 expõe a versão mais simples da lei do valor: a de lei da determinação do valor pelo tempo de trabalho. Mostra também porque o sentido desta lei, mesmo nesta primeira formulação, já é mais complexo do que costuma ser entendido. A seção 5.4.3 expõe o entendimento da lei do valor como lei da distribuição do trabalho social, e questiona 
se isto pode significar, como pretendem vários autores, lei do equilíbrio na distribuição do trabalho social. A seção 5.4.4 expõe o entendimento da lei do valor como lei da minimização do tempo de trabalho abstrato, e mostra como, assim entendida, ela é uma lei dinâmica, que se vincula com as leis gerais de desenvolvimento da economia capitalista. Finalmente, a seção 5.4.5 resume algumas conclusões.

A seção 5.5 retomará a discussão da lei do valor, tratando do plano internacional.

\subsection{2 — Lei da determinação do valor pelo tempo de trabalho}

Quando se trata da lei do valor na economia marxista, o primeiro entendimento é o de que esta lei diz que os valores das mercadorias são proporcionais ao tempo de trabalho socialmente necessário à sua produção ou, o que é equivalente, que os seus preços são, $n a$ média, proporcionais a este tempo de trabalho. O próprio Marx referiu-se à lei do valor nestes termos:

Podemos, então, estabelecer como lei geral o seguinte:

Os valores das mercadorias estão na razão direta do tempo de trabalho invertido em sua produção e na razão inversa das forças produtivas do trabalho empregado.

$(\ldots)$

Os preços do mercado não fazem mais do que expressar a quantidade social média de trabalho que, nas condições médias de produção, é necessária para abastecer o mercado com determinada quantidade de um certo artigo [Salário, Preço e Lucro, p. 157].

A seqüência do texto fala das oscilações dos preços de mercado em torno do valor, identificado inclusive com o preço natural de Adam Smith; Marx afirma que "se a oferta e a procura se equilibram, os preços das mercadorias no mercado corresponderão a seus preços naturais, isto é, a seus valores, os quais se determinam pelas respectivas quantidades de trabalho necessárias à sua produção" [Salário, Preço e Lucro, p. 158].

Ocorre que a lei do valor formulada desta maneira tem sido um dos principais alvos de ataque dos críticos de Marx desde pelo menos o fim do século XIX, com a publicação das críticas de Böhm-Bawerk ${ }^{32}$. De fato, vimos no Capítulo 4 que, quando consideramos uma economia capitalista com muitos capitais que concorrem entre si, com composições

\footnotetext{
${ }^{32}$ Como vimos no Capítulo 4.
} 
orgânicas e tempos de rotação distintos, os preços não podem ser, na média, proporcionais aos valores. Os preços médios devem corresponder ao que Marx chamou de preços de produção - sua versão para os preços naturais de Adam Smith —, e não aos valores. A formulação de Salário, Preço e Lucro citada acima deve ser considerada, portanto, como uma simplificação, ou como uma aproximação pouco rigorosa da realidade, justificável pelo caráter popular da exposição.

Ao tratar destas questões em $O$ Capital, Marx é bastante mais cuidadoso. Assim, depois de chegar ao valor como objetivação do trabalho abstrato em mercadorias, medido pelo tempo de trabalho socialmente necessário, diz que o valor se expressa em dinheiro como preço. Mas já no Capítulo III do Livro I, como vimos na subseção 1.3.1 do Capítulo 1, na subseção 3.3.6 do Capitulo 3 e na terceira seção deste capítulo, ele afirma a possibilidade de uma "incongruência quantitativa" entre o preço e a grandeza de valor, e não restringe esta possibilidade à ocorrência de oscilações do preço em torno do valor [O Capital I-I, p. 91]. Logo adiante, aliás, como vimos na subseção 1.3.1, ele menciona também a possibilidade de uma "contradição qualitativa": "coisas que, em si e para si, não são mercadorias, como por exemplo consciência, honra etc., podem ser postas à venda por dinheiro por seus possuidores e assim receber, por meio de seu preço, a forma mercadoria" [ $\mathrm{O} C \mathrm{C}$ pital I-I, p. 91].

Ou seja, fica registrado desde o início de $O$ Capital que a relação entre valor e preço é mais complexa do que a sugerida pela fórmula: o preço é a expressão do valor em dinheiro; é afirmado que os preços podem desviar-se do valor, e a natureza precisa destes desvios não é estudada. Quando esta questão é retomada no Livro III, a partir do Capítulo VIII, com a teoria da transformação dos valores em preços de produção e com a discussão da relação dos preços de produção com os preços de mercado, fica claro que os preços médios não podem, em geral, ser iguais aos valores.

O sentido, então, da lei do valor neste primeiro aspecto é, afinal, o seguinte: o valor, como objetivação de tempo de trabalho abstrato, só pode ser criado na produção; na circulação, ele se expressa como preço, e pode haver então transferências do valor já determinado na produção ${ }^{33}$.

\footnotetext{
${ }^{33}$ Como vimos na subseção 1.3.1 do Capítulo 1.
} 


\subsection{3 - Lei da regulação da distribuição do trabalho social}

A lei do valor tem também um segundo sentido, claro desde o Capítulo I do Livro I de O Capital: o de realizar a distribuição do trabalho social, numa forma de organização econômica em que os produtores não se relacionam diretamente, mas apenas indiretamente, através do intercâmbio dos seus produtos, no mercado. Este segundo sentido, aliás, é um desenvolvimento do anterior, já que se associa estreitamente aos desvios dos preços em relação aos valores.

Este tema já foi trabalhado por diversos economistas, entre os quais se destaca Isaak Rubin. Um dos seus argumentos centrais [Rubin 1980] é que o sentido principal da teoria do valor de Marx não vai do valor ao trabalho (isto é, seu objetivo principal não é o de descobrir que por trás do valor das mercadorias está o trabalho humano), mas sim do trabalho ao valor. Trata-se de explicar por que, na economia mercantil-capitalista, o trabalho assume a forma de valor dos produtos do trabalho (das mercadorias). Nesta linha de raciocínio, a razão fundamental para que o trabalho assuma a forma de valor das mercadorias é que esta é a única possibilidade de regulação da distribuição social do trabalho em uma economia de produtores privados, que não articulam previamente seus gastos de trabalho. A variação dos preços das mercadorias em torno dos valores é, portanto, necessária diante da necessidade de corrigir o excesso ou a escassez de determinadas mercadorias: as escassas verão seus preços subirem, as excedentes seus preços baixarem, e este movimento de preços leva à correção tendencial dos desequilíbrios. A lei do valor é vista assim como uma lei que regula a distribuição do trabalho social.

Esta interpretação da lei do valor, enfatizada brilhantemente por Rubin, tem muitos méritos. Vimos, na subseção 4.3.2 do Capítulo 4, que é a partir dela que ele desenvolve um tratamento da questão da transformação dos valores em preços de produção rico e coerente. Ao mencionar que na economia capitalista a distribuição do trabalho social depende da distribuição dos capitais, passa de forma natural da idéia de preços que igualam o valor na média para a idéia de preços cuja média é dada pelos preços de produção.

Contudo, interpretar a lei do valor sobretudo como uma lei da distribuição traz um risco, o de reforçar excessivamente seu caráter de lei de equilíbrio. O próprio Rubin sofre deste problema, ao dizer que "[a] lei do valor é a lei de equilibrio da economia mercantil" [Rubin 1980, p. 82]. Mas ele aparece ainda mais claramente em outros autores que defendem uma concepção semelhante. 
Assim, Paul Sweezy diz que:

(...) a lei por Marx chamada "lei do valor" resume as forças que atuam numa sociedade produtora de mercadorias e que regulam: $a$ ) as razões de troca entre as mercadorias, $b$ ) a quantidade de cada mercadoria produzida, $c$ ) a distribuição da força de trabalho aos vários ramos da produção. (...) As forças em atividade incluem, de um lado, a produtividade do trabalho nos vários ramos de produção e as necessidades sociais modificadas pela distribuição de renda. Do outro lado, as forças equilibradoras do mercado, a concorrência da oferta e procura. Usando uma expressão moderna, a lei do valor é essencialmente uma teoria do equilíbrio geral desenvolvida em primeiro lugar com referência à produção de mercadorias simples e mais tarde adaptada ao capitalismo [Sweezy 1967, p. 81].

Será correto tratar a lei do valor como sendo "essencialmente uma teoria do equilíbrio geral"? Certamente não; uma teoria do equilíbrio geral não poderia estar de acordo com a visão de Marx do capitalismo - a de um sistema que não tende ao equilíbrio, qualquer que seja o sentido que se queira dar a isto ${ }^{34}$.

Os riscos desta interpretação são explicitados ainda mais claramente por Maurice Dobb. Segundo este autor, a lei do valor mostra que:

[A] utilização da força de trabalho social não é arbitrária, mas está sujeita a uma definida lei do custo graças à "mão invisível" das forças competitivas a que se referia Adam Smith [Dobb 1945, p. 49].

Moishe Postone comenta de modo apropriado:

A formulação de Dobb torna explícito o que fica implícito em tais interpretações da lei do valor de Marx — isto é, que esta lei é basicamente similar à 'mão invisível' de Adam Smith. A questão, entretanto, é se as duas podem ser de fato igualadas [Postone 1993, p. $50]$.

Ernest Mandel, por outro lado, formula a lei do valor como uma lei da distribuição, mas não incorre no erro de tratá-la como uma lei do equilíbrio. No "Glossário" de seu $O$ Capitalismo Tardio, diz o seguinte:

Lei do Valor. Mecanismo econômico de uma sociedade de produtores privados que distribui a força de trabalho total à disposição da sociedade (e assim todos os recursos

\footnotetext{
${ }^{34}$ Como vimos na seção 5.2, o capitalismo tem tendências equilibradoras e desequilibradoras, e as primeiras não predominam.
} 
materiais necessários à produção) entre os vários ramos de produção, pela mediação da troca de todas as mercadorias por seu valor (por seus preços de produção, no modo de produção capitalista). Sob o capitalismo, esta lei determina o padrão de investimento isto é, a entrada e saída de capital dos diversos ramos de produção, segundo desvio de sua taxa de lucro específica relativamente à taxa média de lucro [Mandel 1985, p. 413].

Apesar desta formulação da lei do valor como lei da distribuição ${ }^{35}$, não há na obra de Mandel nenhuma idéia de que esta lei seria uma "lei do equilíbrio" (e menos ainda de "equilíbrio geral") ou de que seria equivalente à "mão invisível" de Adam Smith. Pelo contrário, ele enfatiza sempre os desequilíbrios da economia capitalista, e a tendência a que se ampliem. Voltaremos a mencionar a interpretação de Mandel da lei do valor na seção 5.6 .

\subsection{4 — Lei da minimização do tempo de trabalho abstrato}

Há um terceiro sentido para lei do valor que integra os dois anteriores como momentos, e que dá um sentido geral a esta lei que é muito diferente do de uma "lei do equilíbrio geral" ou da "mão invisível" de Adam Smith. Para introduzi-lo, podemos retomar a discussão, realizada na seção 5.2, dos dois tipos de concorrência.

A concorrência intersetorial — segundo a qual os capitais deslocam-se entre os diversos setores, buscando as taxas de lucro mais elevadas - leva tendencialmente os preços de mercado para uma média constituída pelos preços de produção, e promove a tendência à igualação das taxas de lucro. Numa situação em que todos os capitais recebessem a taxa de lucro média, não haveria incentivos a deslocamentos; esta forma de concorrência tem, portanto, um caráter equilibrador.

Existe, contudo, um segundo tipo de concorrência, a concorrência intra-setorial, isto é, interna a cada setor, cujo efeito é desequilibrador. Cada capitalista procura reduzir os valores individuais das mercadorias que produz (por aumento de produtividade, por superexploração, ou por outros métodos — voltaremos a este ponto na última seção deste capítulo), de modo a obter uma mais-valia extra. Se nos centramos no aumento de produtividade, este processo não tem fim. Como vimos na subseção 5.2.4, a produtividade superior

\footnotetext{
${ }^{35}$ Falar da distribuição incluindo as decisões de investimento implica falar da produção — da expansão ou da contração dos setores produtivos — mas não do modo de produção.
} 
à média de um momento se transforma na produtividade média do momento seguinte, e os capitalistas, em busca de mais-valia extra, procurarão introduzir novos aumentos de produtividade.

Cria-se, portanto, uma dialética entre valores individuais e valores sociais, que se torna um novo aspecto da lei do valor — o que a transforma, na feliz expressão de John Weeks, na "lei da minimização do tempo de trabalho abstrato" [Weeks 1981, p. 33].

Este autor explica este aspecto da lei do valor da seguinte maneira:

À medida que alguns capitais consomem o capital produtivo mais eficientemente, seus produtos aumentam correspondentemente, e os capitais menos eficientes devem emular os mais eficientes ou ser eliminados da produção. É por este processo que o tempo de trabalho socialmente necessário é estabelecido em cada indústria. O trabalho concreto consumido na produção - vivo e morto - é tornado comparável na troca e normalizado através da concorrência. Desta maneira, o valor começa a dominar a produção. O tempo de trabalho socialmente necessário existe 'às costas' de cada capitalista, e sem entrar na consciência dos capitalistas regula sua produção. Esta é a operação da lei da minimização do trabalho concreto $^{36}$ na produção [Weeks 1981, p. 48] $]^{37}$.

Moishe Postone é quem mais enfatiza este aspecto da lei do valor. Para ele, o elemento central da lei do valor é a seguinte dialética: aumento de produtividade para um capital — redução do valor individual e obtenção de mais-valia extra — generalização do novo nível de produtividade e perda da mais-valia extra - recomeço do processo. A partir daí, conclui:

Na medida em que é possível falar de uma "lei do valor" marxiana, este efeito de moinho de pisar (treadmill effect) é sua determinação inicial; como veremos, ele descreve um pa-

\footnotetext{
${ }^{36} \mathrm{Na}$ frase citada anteriormente Weeks fala em minimização do tempo de trabalho abstrato. Contudo, não há incoerência neste ponto, uma vez que o tempo de trabalho abstrato é definido a partir da normalização do trabalho concreto.

${ }^{37}$ Weeks menciona igualmente o aspecto da lei do valor como lei da distribuição dos capitais: "a concorrência força todos os produtores a produzir com o mínimo insumo de tempo de trabalho concreto, e força uma tendência para uma taxa de lucro normal em todas as indústrias. Estes dois aspectos da lei do valor podem ser chamados de 'lei do tempo de trabalho socialmente necessário' e de 'lei da tendência da igualação da taxa de lucro"” [Weeks 1981, p. 40]. Além disto, como veremos abaixo, chama a atenção ainda para um terceiro aspecto desta lei, relacionado com o de redução do tempo de trabalho.
} 
drão de transformação e reconstituição sociais contínuas como características da sociedade capitalista. A lei do valor, então, é dinâmica e não pode ser adequadamente compreendida em termos de uma teoria de equilíbrio do mercado. Uma vez considerada a dimensão temporal do valor - compreendido como uma forma específica de riqueza que difere da riqueza material - torna-se evidente que a forma do valor implica a dinâmica acima desde o início [Postone 1993, p. 290].

Por efeito "moinho de pisar"38 e por "um padrão de transformação e reconstituição sociais contínuas", Postone refere-se à dialética resumida acima.

Neste sentido, portanto, a lei do valor refere-se à constituição e reconstituição permanentes de uma norma produtiva. É ela que dá à sociedade capitalista seu grande dinamismo, e que torna fraca e secundarizada qualquer idéia de tendência para um equilíbrio: qualquer equilíbrio tendencial é desfeito muito antes de poder realizar-se. A "mão invisível” só pode funcionar muito parcialmente.

É interessante observar que já na Miséria da Filosofia, há uma passagem muito interessante sobre a lei do valor que aponta na direção de defini-la como lei da redução do tempo de trabalho e, associadamente, como lei de depreciação do tempo de trabalho:

Toda nova invenção que permite produzir em uma hora o que foi produzido até aqui em duas horas deprecia todos os produtos similares que se encontram no mercado. A concorrência força o produtor a vender o produto de duas horas tão barato quanto o produto de uma hora. A concorrência realiza a lei segundo a qual o valor relativo de um produto é determinado pelo tempo de trabalho necessário para produzi-lo. O tempo de trabalho servindo de medida do valor venal torna-se assim a lei de uma depreciação contínua do trabalho. Diremos mais. Haverá depreciação não apenas para as mercadorias levadas ao mercado, mas também para os instrumentos de produção, e para toda uma instalação [Misère de la Philosophie, p. 39].

No chamado Capitulo VI Inédito de O Capital esta dinâmica é relacionada com outra lei fundamental da economia capitalista:

O produtor real como simples meio de produção; a riqueza material em contradição com o (e a expensas do) indivíduo humano. Produtividade do trabalho, em suma = máximo de

\footnotetext{
${ }^{38} \mathrm{O}$ "moinho de pisar" é um moinho movimentado pelos passos do trabalhador, de tal maneira que quem o movimenta permanece sempre na mesma posição, por mais que acelere seu passo.
} 
produtos com mínimo de trabalho; daqui o maior embaretecimento possível das mercadorias. Independentemente da vontade deste ou daquele capitalista, isto converte-se na lei do modo de produção capitalista. E esta lei só se realiza implicando outra, a saber: a de que não são as necessidades existentes que determinam o nível da produção mas de que é a escala de produção - sempre crescente e imposta, por sua vez pelo próprio modo de produção - que determina a massa do produto. O seu objetivo (é) que cada produto etc. contenha o máximo possível de trabalho não pago, e isso só se alcança mediante a produção para a própria produção. Isto apresenta-se por um lado como lei, porquanto o capitalista que produz em pequena escala incorporaria no produto um quantum de trabalho maior do que o socialmente necessário ${ }^{39}$. Apresenta-se portanto como uma aplicação adequada da lei do valor que só se desenvolve plenamente com base no modo de produção capitalista. Porém, aparece por outro lado como impulso do capitalista, que para violar esta lei ou para a utilizar astutamente em seu proveito procura fazer descer o valor individual da sua mercadoria abaixo do valor socialmente determinado [Capítulo VI Inédito de O Capital, pp. 1078].

A lei do valor transforma-se então em lei da produção pela produção, e em lei da subordinação crescente do trabalhador ao capital. Neste último aspecto, como observa John Weeks, a lei do valor é também a lei da alienação do trabalhador:

A lei do valor, então, não é apenas a lei do tempo de trabalho sob o capitalismo (divisão do trabalho), a lei da mais-valia (exploração), mas também o mecanismo da alienação. Quando o capitalismo é imaturo e os trabalhadores levam para o processo de trabalho controlado pelos capitalistas qualificações e conhecimentos necessários à produção, esta alienação é primariamente a alienação do trabalhador do seu produto. Na medida em que o capitalismo se desenvolve e a divisão do trabalho se amplia no processo de produção, o trabalhador crescentemente se torna alienado do próprio processo de trabalho, reduzido a mera fonte de energia homogênea, abstrata. $O$ trabalhador se torna na forma e na essência

\footnotetext{
${ }^{39}$ Marx, aqui, supõe implicitamente: que o pequeno capitalista não teria os ganhos de escala que o grande capitalista teria; que o socialmente necessário seria determinado pelos grandes capitalistas, ou seja, pelo trabalho mais produtivo, ou então por uma produtividade intermediária, que seria de qualquer maneira maior do que a disponível para o pequeno capitalista. Adota portanto a suposição básica da existência de rendimentos crescentes de escala. Além disto, seu raciocínio se baseia também em que o "quantum de trabalho maior do que o socialmente necessário" não geraria mais valor, ou seja, seria desperdiçado. Assim, a hora de trabalho do trabalhador que trabalha para o pequeno capitalista geraria menos valor do que a hora de trabalho média.
} 
meramente uma extensão do capital, de tal modo que o poder cooperativo das massas aparece como poder produtivo do capital [Weeks 1981, pp. 48-9].

Fica claro, portanto, que a lei do valor não pode ser entendida apenas nem como lei da determinação do valor pelo tempo de trabalho, nem como lei da regulação da distribuição do trabalho social. Estes momentos existem, mas ela vai além deles. Seu sentido mais profundo é o de uma lei que define e redefine continuamente uma norma produtiva, que cria a partir daí uma lógica de produção pela produção e que dá à economia capitalista um grande dinamismo, juntamente com um caráter profundamente contraditório.

A lei do valor, naturalmente, é uma lei da concorrência. A fixação nos dois primeiros aspectos da lei do valor implica mirar apenas a questão da relação entre valores e preços, e portanto a concorrência intersetorial entre os capitais. No entanto, a dialética valor individual - valor de mercado, e a concorrência intra-setorial, são aspectos não menos fundamentais da economia capitalista; são captados pela terceira dimensão da lei do valor, o de lei da minimização do tempo de trabalho abstrato. Ela determina (e redetermina), portanto, uma norma produtiva, que tem implicações sobre a própria organização da produção, sobre os métodos empregados etc., e este é seu sentido mais profundo. Muito mais do que uma lei da distribuição (dos capitais e do trabalho social), a lei do valor é uma lei da produção.

\section{5 - VALORES E PREÇOS NO PLANO INTERNACIONAL}

\subsection{1 - Marx sobre valores e preços internacionais em $O$ Capital}

A definição dos preços e dos valores internacionais, especialmente a destes últimos, apresenta uma série de dificuldades. Esta seção sugere, com base na abordagem da teoria do valor desenvolvida neste trabalho, uma maneira de resolvê-las e estabelece, a partir daí, uma maneira de caracterizar o intercâmbio desigual. O quadro teórico construído para tomar em consideração as diferenças internacionais pode ser usado, também, para o exame de espaços econômicos diferenciados no interior de um mesmo país.

Começamos, nesta subseção, pelo exame de alguns textos em que Marx tratou explicitamente destes temas.

No Capítulo XX do Livro I, comentando a diversidade nacional dos salários, MarX escreveu o seguinte: 
$\mathrm{Na}$ comparação dos salários nacionais devem ser pois considerados todos os momentos determinantes da variação na grandeza do valor da força de trabalho, preço e volume das primeiras necessidades vitais naturais e historicamente desenvolvidas, custos de educação do trabalhador, papel do trabalho feminino e infantil, produtividade do trabalho, sua grandeza extensiva e intensiva. Mesmo a comparação mais superficial exige, antes de tudo, reduzir o salário médio diário para os mesmos ofícios em diferentes países à igual grandeza da jornada de trabalho. Após tal equiparação dos salários diários, o salário por tempo tem de ser de novo traduzido em salário por peça, pois apenas o último permite medir tanto o grau da produtividade como o da grandeza intensiva do trabalho.

Em cada país vale certa intensidade média do trabalho, abaixo da qual o trabalho para a produção de uma mercadoria consome mais tempo que o socialmente necessário, e por isso não conta como trabalho de qualidade normal. Apenas um grau de intensidade que se eleva acima da média nacional, num país dado, muda a medida do valor pela mera duração do tempo de trabalho. Não ocorre o mesmo no mercado mundial, cujas partes integrantes são os vários países. A intensidade média do trabalho muda de país para país; aqui é maior, lá menor. Essas médias constituem assim uma escala, cuja unidade de medida é a unidade média do trabalho universal. Comparado com o menos intensivo, o trabalho nacional mais intensivo produz pois, em tempo igual, mais valor, que se expressa em mais dinheiro $[O$ Capital I-II, p. 139-40; El Capital I-II, p. 683-4].

A diferença entre o plano nacional e o internacional, como descrita nestes parágrafos, está em que no interior de um mesmo país há uma tendência à homogeneização da intensidade do trabalho, o que estabelece uma intensidade-padrão que serve de base para a medida do valor pela duração do tempo de trabalho - os casos de maior ou menor intensidade são então avaliados em comparação com esta intensidade-padrão. No plano internacional, não há tal tendência à homogeneidade, o que há é o estabelecimento de uma escala de intensidades médias nacionais. No entanto, também aqui se define uma unidade de medida média internacional (uma média das médias nacionais). A diferença entre os dois planos se restringe, portanto, a que no plano nacional existe uma intensidade-padrão que serve de base, enquanto no plano internacional a intensidade de referência é dada apenas por uma média.

A diferença entre o plano internacional e o nacional se amplia quando levamos em conta a questão da produtividade do trabalho:

Porém a lei do valor é modificada ainda mais em sua aplicação internacional pelo fato de que no mercado mundial o trabalho nacional mais produtivo conta também como mais in- 
tensivo, sempre que a nação mais produtiva não seja obrigada pela concorrência a reduzir o preço de venda de sua mercadoria a seu valor.

Na medida em que a produção capitalista é desenvolvida num país, na mesma medida elevam-se aí também a intensidade e a produtividade nacional do trabalho acima do nível internacional. As diferentes quantidades de mercadorias da mesma espécie, que são produzidas em tempo igual de trabalho em diferentes países, têm, portanto, valores internacionais desiguais, que se expressam em preços diferentes, isto é, em somas de dinheiro que diferem conforme os valores internacionais. O valor relativo do dinheiro será portanto menor na nação em que o modo de produção capitalista é mais desenvolvido do que naquela em que é menos desenvolvido. Segue-se, portanto, que o salário nominal, o equivalente da força de trabalho expresso em dinheiro, será também mais alto na primeira nação que na segunda; o que de forma alguma significa que isso também é válido para o salário real, isto é, para os meios de subsistência colocados à disposição do trabalhador.

Porém, mesmo abstraindo essa diferença relativa do valor do dinheiro em diferentes países, será freqüentemente verificado que o salário diário, semanal, etc. na primeira nação é mais alto que na segunda, enquanto o preço relativo do trabalho, isto é, o preço do trabalho em relação tanto à mais-valia como ao valor do produto, na segunda nação é mais alto que na primeira [O Capital I-II, p. 140; El Capital I-II, p. 684].

Nesta passagem há dois aspectos que devem ser comentados. Em primeiro lugar, "no mercado mundial o trabalho mais produtivo conta também como mais intensivo" vale dizer, para as produtividades nacionais desiguais estabelece-se a mesma escala mencionada antes para as intensidades - "sempre que a nação mais produtiva não seja obrigada pela concorrência a reduzir o preço da mercadoria a seu valor" ${ }^{\natural 0}$. Este parágrafo pode ser interpretado no sentido de que, no plano internacional, há uma diferenciação dos valores nacionais (correspondentes neste contexto aos valores individuais), e que o valor internacional (correspondente ao valor social) expressará portanto mais tempo de trabalho do país menos produtivo, e menos tempo de trabalho no país mais produtivo. A diferença entre o que se passa no plano internacional com relação ao caso nacional é que internacio-

\footnotetext{
40 "A seu valor", neste contexto, significa claramente "ao equivalente em horas de trabalho", ou seja, a seu valor individual. A não redução do preço da mercadoria a seu valor individual por parte do país mais produtivo significa, portanto, a não homogeneização do conteúdo em tempo de trabalho de uma unidade de valor.
} 
nalmente não há tendência à generalização do progresso técnico (ou, se houver ${ }^{41}$, ela será muitíssimo mais lenta)..

Em segundo lugar, quanto ao valor do dinheiro: fica claro, no contexto, que valor do dinheiro é seu conteúdo em tempo de trabalho; ele é menor no país mais produtivo porque representa menos tempo de trabalho. Desta maneira, os preços monetários serão mais elevados ${ }^{42}$. Por isto, o salário nominal será maior; mas, uma vez que o maior progresso técnico leva à produção de mais-valia relativa, o preço relativo do trabalho (em relação ao valor do produto ou à mais-valia) será menor.

No Capítulo XIV do Livro III ("Causas contrariantes" da "Lei da queda tendencial da taxa de lucro", item V: "Comércio exterior") podemos ler o seguinte:

Capitais investidos no comércio exterior podem proporcionar taxa de lucro mais elevada, porque aqui, em primeiro lugar, se concorre com mercadorias que são produzidas em outros países com menores facilidades de produção, de forma que o país mais adiantado vende suas mercadorias acima de seu valor, embora mais barato do que nos países concorrentes. À medida que o trabalho do país mais adiantado é valorizado aqui como trabalho de peso específico mais elevado, a taxa de lucro sobe, pois o trabalho que não é pago como qualitativamente mais elevado é vendido como tal. A mesma relação pode ocorrer no caso do país para onde são enviadas mercadorias e do qual são adquiridas mercadorias; que este, a saber, dê mais trabalho objetivado in natura do que recebe e que, não obstante, obtenha assim a mercadoria a preço mais baixo do que ele mesmo poderia produzir. Exatamente como o fabricante que usa uma nova invenção antes de sua generalização vendendo mais barato do que seus concorrentes, e mesmo assim vende acima do valor individual de sua mercadoria, ou seja, aproveita como mais trabalho a força produtiva de trabalho especificamente mais elevada por ele empregada [O Capital III-IV, p. 172].

\footnotetext{
${ }^{41}$ Há uma grande polêmica a este respeito, que se traduz por exemplo na pergunta: o livre comércio e a liberdade de movimentos de capitais devem gerar uma tendência à convergência internacional dos níveis de renda? A economia neoclássica responde afirmativamente a esta questão, enquanto outras correntes teóricas são muito mais céticas, ou têm posição claramente por uma resposta negativa.

${ }^{42}$ Este argumento sobre a variação no valor do dinheiro (ou seja, no nível dos preços), que remonta a Ricardo, não está bem desenvolvido. Corresponde ao que modernamente é chamado de "Harrod-BalassaSamuelson effect" [Obstfeld and Rogoff 1996, Chapter 4], que comentaremos na subseção 5.5.4.
} 
Neste parágrafo são retomadas algumas das idéias já expostas acima: o país que tem maiores "facilidades de produção" vende suas mercadorias "acima do seu valor" (isto é, acima de seu valor individual - este termo aparece explicitamente, numa comparação com o caso nacional), embora mais barato do que nos países concorrentes (isto é, abaixo do valor individual dos concorrentes); isto significa intercâmbio de quantidades desiguais de trabalho. Há um comentário interessante, embora bastante óbvio, que não tinha aparecido antes: o país menos produtivo dá mais trabalho objetivado do que recebe, mas ainda assim obtém a mercadoria "a preço mais baixo do que ele mesmo poderia produzir". Isto significa que este país dá pela mercadoria mais trabalho do que ela custou no país de origem, mas ainda assim a compra por menos trabalho do que se a tivesse de produzir. Portanto, um intercâmbio desigual de quantidades de trabalho não é obrigatoriamente desfavorável para o país que "perde" horas de trabalho ${ }^{43}$.

\subsection{2 - Particularidades do valor e dos preços no plano internacional}

Os valores e os preços no plano internacional têm uma natureza distinta da que têm no interior de um mesmo espaço econômico. A principal razão é a persistência de desigualdades duradouras entre condições nacionais de produção - tecnológicas, institucionais -, o que faz que não haja tendência à "homogeneização" do trabalho, à constituição generalizada do mesmo padrão de trabalho simples. Na verdade, já há heterogeneidade do trabalho quando consideramos desigualdades nas condições de produção e a concorrência intra-setorial no plano nacional (seção 5.2); mas no plano internacional as diferenças tendem a ser mais duradouras, não são tão transitórias como no plano nacional; a dialética valores individuais - valor social é truncada. $\mathrm{O}$ valor traduzido internacionalmente não é, portanto, determinado como "puro dispêndio de força de trabalho"; as distintas intensidades e produtividades nacionais são levadas em conta, e formam-se projeções internacionais dos valores nacionais (correspondentes aos valores individuais) que se ordenam em uma escala. No entanto, uma vez que há comércio internacional, e se supomos que os preços

\footnotetext{
${ }^{43}$ De fato, o problema deste país está na produção menos eficiente, não no intercâmbio (subseção 5.3.6).
} 
das mercadorias transacionadas (tradables) não podem divergir excessivamente, há formação de preços internacionais ${ }^{44}$.

A diferença duradoura de condições de produção não diz respeito apenas aos setores que entram diretamente nas transações internacionais, isto é, que produzem tradables. Vimos na subseção 5.2.5 que, na medida em que o progresso técnico se generaliza em cada setor e o valor social de seus produtos cai, ocorre uma "difusão solidária" do aumento da produtividade do trabalho. É todo o trabalho realizado no país - no espaço econômico unificado em que o aumento da produtividade se dá - que se torna mais produtivo (no sentido de que a hora de trabalho simples se troca por mais valores de uso); isto acontece mesmo para o trabalho que não foi beneficiado por progresso técnico e cuja produtividade física, portanto, não se modificou. O truncamento do processo de difusão do progresso técnico no plano internacional, portanto, implica a constituição de uma diferenciação da produtividade do trabalho entre as nações, não apenas entre os setores nos quais a produtividade física evoluiu de modo diferente.

Esta diferenciação nacional de produtividade implica uma diferenciação duradoura na magnitude do valor produzido pela hora de trabalho de cada país quando traduzido internacionalmente. Assim, podemos dizer que, tal como acontece com a determinação dos salários ${ }^{45}$, a determinação do valor internacional adicionado pela hora de trabalho abstrato (simples) tem uma natureza macroeconômica.

O ordenamento da capacidade de produzir valor internacional em uma escala, a partir das distintas produtividades nacionais do trabalho, pode ser chamado de normalização internacional do tempo de trabalho. Como vimos no Capítulo 3, subseção 3.3.3, a normalização propriamente dita do trabalho se dá no interior de um mesmo setor, da produção das mesmas mercadorias; mas podemos estender este conceito ao plano internacional $^{46}$.

\footnotetext{
44 Mesmo que avaliemos que não se formam verdadeiros preços de produção, ou preços comerciais, internacionais. A formação destes preços supõe a formação de uma taxa geral de lucro internacional, o que é bastante discutível; voltaremos a esta questão na próxima subseção.

${ }^{45}$ Cf. subseção 5.2.5.

${ }^{46}$ Neste plano, não se trata, naturalmente, da produção da mesma mercadoria, mas da produção de um determinado conjunto de bens, isto é, da totalidade dos bens produzidos em cada país.
} 


\subsection{3 - Taxa de câmbio, valores internacionais e preços}

Como estabelecer a correspondência em termos de trabalho abstrato (de valor) entre as horas de trabalho dos diversos países?

A questão-chave é definir como tratar a taxa de câmbio: embora não haja homogeneização do trabalho de forma completa no plano internacional, os diversos valores nacionais são traduzidos internacionalmente quando se expressam em uma moeda internacional de referência. Desta maneira, é estabelecida uma correspondência entre os tempos nacionais de trabalho (simples) abstrato. Dizendo de outra maneira, uma unidade monetária internacional expressa tempos diferentes de trabalho abstrato em cada país; estes tempos são portanto normalizados internacionalmente, passam a expressar a magnitude do "tempo de trabalho abstrato padronizado internacionalmente".

A determinação da taxa de câmbio que deve ser usada para estabelecer a correspondência dos valores, contudo, não é uma coisa simples. Não podemos usar a taxa de câmbio corrente, que é uma taxa em preços (de mercado). Tampouco podemos usar uma taxa de câmbio média, ou alguma variação da média — esta seria uma taxa de câmbio em termos dos preços correspondentes aos preços de produção ou, mais exatamente, aos preços comerciais nacionais ${ }^{47}$.

Como determinar uma taxa de câmbio em valor? A maneira mais natural é tomar como referência o que acontece com a quantificação do trabalho abstrato no plano nacional, e com a formação do valor social a partir dos distintos valores individuais. Neste processo, quantidades de trabalho distintas (isto é, tempos de trabalho concreto distintos), mas que permitem produzir valores de uso qualitativa e quantitativamente iguais, são consideradas iguais em termos de trabalho abstrato, isto é, são normalizadas. Em se tratando da realização de uma normalização internacional, que envolve o conjunto do

\footnotetext{
${ }^{47}$ Este é o caráter dos conceitos da taxa de câmbio tendencial proposta por Guglielmo Carchedi [1991, pp. 248-250] e da taxa de câmbio determinada a partir dos custos unitários reais defendida por Anwar Shaikh [1998b; 1999].
} 
trabalho realizado em cada país, não podemos fazê-la a partir de um único valor de uso; é preciso partir do conjunto dos bens produzidos em cada país ${ }^{48}$.

A taxa de câmbio que procuramos será, então, a que estabelece a igualdade em uma moeda internacional dos valores de um conjunto de bens representativo da totalidade dos bens de cada país. Como não dispomos de cálculos de valores dos bens de muitos países, há a alternativa de usar como proxy a taxa que estabelece a igualdade do preço de uma cesta representativa de bens: ou seja, a taxa de câmbio que estabelece a paridade de poder de compra (PPP, Purchasing Power Parity) ${ }^{49}$. É possível então contar então com uma referência cujo cálculo já está consolidado pela experiência.

A taxa PPP pode ser calculada a partir da equação: $\varepsilon=P_{2}{ }^{*} / P_{1}$, em que $P_{1}$ e $P_{2}{ }^{*}$ são os níveis de preços de uma cesta de bens representativa, respectivamente no país 1 e no país 2, em termos da moeda de cada um (o índice subscrito indica a qual país o nível de preços se refere, e o asterisco indica tratar-se de preços em termos da moeda do país 2). $\varepsilon$ é a taxa de câmbio nominal do país 1, definida como o preço da moeda do país 2 em termos da moeda do país 1 .

Se dispomos de uma taxa de câmbio em valor, o valor internacional, ou o valor nacional expresso internacionalmente, será o valor nacional ajustado por esta taxa ${ }^{50}$. É

\footnotetext{
${ }^{48}$ Poderia ser questionada a escolha do conjunto dos bens de cada país para calcular esta taxa, com base no argumento de que seria mais correto tomar apenas os tradables. Entretanto, parece mais indicado tomar o conjunto dos bens; afinal, o que pretendemos é normalizar a produção de valor de cada país, a partir da desigualdade da força produtiva média do seu trabalho (a força produtiva do trabalho de cada país só pode ser entendida como uma média das forças produtivas referentes à produção de cada mercadoria); ela deve ser calculada, portanto, sobre o conjunto da produção nacional.

49 Não estamos sugerindo, de maneira alguma, que as taxas de câmbio efetivas tendam a este valor. Ao contrário; como argumentaremos na subseção seguinte, elas tendem a divergir deles quanto mais os níveis de produtividade relativos dos países divirjam. Com relação à proximidade entre a taxa PPP e a taxa em valor que buscamos, ela dependerá, naturalmente, da cesta de bens representativa escolhida. Estas taxas só coincidiriam para dois países que produzam exatamente os mesmos bens, na mesma quantidade (neste caso, a soma dos valores expressos em dinheiro seria igual à soma dos preços).

${ }^{50}$ É preciso também calcular os valores nacionais das mercadorias, o que tampouco é simples. Muitos autores já têm se dedicado a esta questão; entre outros: Shaikh [1984, 1998a], Fred Moseley [1991], Valle Baeza [1991, Capítulo VI], Shaikh e Tonak [1994], Carchedi e De Haan [1996], diversos autores em Dunne (ed.)
} 
importante observar que, como projeções internacionais dos valores nacionais, os valores internacionais assim definidos serão em geral desiguais para mercadorias iguais produzidas por países diferentes. Isto se deve ao fato de que o espaço econômico mundial não é plenamente unificado; portanto, os valores nacionais, e suas projeções internacionais, ficam a meio-caminho entre valores individuais e verdadeiros valores sociais internacionais; expressam concorrência e difusão tendencial do progresso técnico ${ }^{51}$ plenas nos espaços nacionais, e limitadas no plano internacional (como vimos na subseção 5.5.2).

Quanto aos preços internacionais, eles devem ser iguais (como vimos igualmente na subseção 5.5.2), ou iguais a menos do impacto dos custos de transporte e distribuição, e das diferenças de taxação. Não precisam, contudo, serem considerados preços de produção ou preços comerciais; isto depende do juízo que façamos sobre a existência ou não de uma tendência internacional à igualação das taxas de lucro. Se julgamos que esta tendência não existe no plano internacional, ou existe de modo muito limitado, os preços internacionais ficarão a meio-caminho entre preços de produção ou preços comerciais nacionais e verdadeiros preços de produção ou preços comerciais internacionais.

Há divergência entre os autores que se ocuparam desta questão quanto à existência ou não de uma tendência à igualação internacional das taxas de lucro. Ernest Mandel, em O Capitalismo Tardio, afirma que esta tendência não existe ${ }^{52}$.

Sob as condições das relações capitalistas de produção, preços uniformes de produção (isto é, uma igualização em larga escala das taxas de lucro) só se apresentam no interior dos mercados nacionais (...). A lei do valor só resultaria em preços uniformes por todo o mundo se ocorresse uma igualização internacional geral da taxa de lucro, em resultado da

[1991]. No entanto, ainda são poucos os países para os quais cálculos dos valores de seus produtos já foram feitos.

${ }^{51}$ Difusão plena do progresso técnico apenas como tendência de generalização do progresso técnico no interior de cada setor; como vimos, este processo leva tempo, e uma igualdade plena das condições técnicas de produção nunca é alcançada.

${ }^{52}$ Ernest Mandel define os valores internacionais de uma maneira distinta da adotada aqui. Não se centra na definição da taxa de câmbio; baseia-se em um conceito de valor médio: "[O] valor no mercado mundial será determinado pelo nível internacional médio dos valores da mercadoria necessários para satisfazer toda a demanda internacional monetariamente efetiva. Esse valor médio pode então superar o do país mais produtivo, assim como pode permanecer muito aquém do valor no país mais atrasado" [Mandel 1985, p. 48]. 
completa mobilidade do capital e da distribuição do capital por todas as partes do mundo, independentemente da nacionalidade ou origem de seus possuidores. Em outras palavras, somente se existisse, na prática, uma economia mundial capitalista homogeneizada, com um único estado mundial capitalista [Mandel 1985, p. 47].

No Capítulo 11 da mesma obra, Mandel cita diversos exemplos de desigualdade nas taxas de lucro. Guglielmo Carchedi [1991] e Anwar Shaikh [1998b; 1999] têm a posição contrária. Carchedi se centra no exame do que se passa no setor oligopolístico internacional, e apresenta dados que apóiam a idéia da convergência das taxas de lucro [Carchedi 1991, seção 7.2, pp. 236-40]. Shaikh argumenta a partir da pressão que as taxas de retorno das obrigações financeiras (que supõe tendencialmente iguais, dada a mobilidade internacional do capital financeiro) exercem sobre as taxas de lucro em cada país; estas tenderiam a se igualar, portanto, mesmo independentemente dos fluxos internacionais de investimento direto [Shaikh 1999, pp. 15-6]. Uma avaliação desta questão, contudo, ultrapassa os objetivos desta tese.

\subsection{4 — Intercâmbio desigual}

A observação de Marx citada ao final da subseção 5.5.1 nos diz que nem todo intercâmbio desigual é desfavorável enquanto intercâmbio. Se queremos avaliar quando o intercâmbio em si mesmo implica perda, e quando isto não acontece, é necessário caracterizar mais precisamente os diversos casos de desigualdade.

A definição do intercâmbio desigual (ou da troca desigual) simplesmente a partir da desigualdade na troca de horas de trabalho não é suficiente. Mandel, por exemplo, diz que

A troca desigual consiste na troca do produto de 300 milhões pelo produto de 1,2 bilhões de horas de trabalho ${ }^{53}$, ou seja, no fato de que, no mercado mundial, a hora de trabalho do país desenvolvido é considerada mais produtiva e intensiva que a da nação atrasada [Mandel 1985, p. 254].

O problema desta maneira de definir intercâmbio desigual é que a troca de mais horas de trabalho menos produtivo por menos horas de trabalho mais produtivo, se isto for feito na proporção correta, não constitui em si mesma uma perda! É necessário realizar a

\footnotetext{
${ }^{53}$ Estes números vêm de um exemplo arbitrário.
} 
normalização internacional do tempo de trabalho, ou seja, não fazer a análise diretamente em termos de horas fisicas de trabalho (ou seja, horas de trabalho concreto), mas sim em termos de horas de trabalho abstrato, ou seja, do valor expresso internacionalmente.

Arghiri Emmanuel, cuja obra L'Échange Inégal, publicada inicialmente em $1969^{54}$, foi a maior responsável pela realização do debate em torno da questão do intercâmbio desigual, trata esta questão em termos de troca desigual de valor, e define de modo mais restrito os casos em que há uma verdadeira desigualdade, isto é, uma desigualdade que implica perda na troca. Fala de um intercâmbio desigual em sentido amplo, vinculado à desigualdade nas composições orgânicas do capital, que não é um verdadeiro intercâmbio desigual, pois não implica perda real na troca; e de um intercâmbio desigual em sentido restrito, que implica perda na troca [Emmanuel 1972, Capítulos 2 e 4]. Como conseqüência dos pressupostos que adota, este último seria provocado unicamente por desigualdades nos salários (nas taxas de mais-valia). A obra de Emmanuel é extremamente sugestiva; sofre, contudo, com a artificialidade dos seus pressupostos e a baixa plausibilidade de seu argumento central — o de que as desigualdades nos salários têm a responsabilidade original pelas desigualdades internacionais e, conseqüentemente, os assalariados dos países ricos participam da exploração do terceiro mundo ${ }^{55}$.

Os diversos autores que intervieram do debate sobre o intercâmbio desigual, ocorrido sobretudo no início dos anos 70, têm posições muito diferentes a respeito. No entanto, nenhum deles deu um papel central à questão da determinação da taxa de câmbio que expressa no plano internacional os valores nacionais; conseqüentemente, propomos aqui um novo quadro conceitual, que segue o critério básico de tratar a desigualdade em termos da troca desigual de valor ${ }^{56}$. Desta forma o tempo de trabalho em cada país é normalizado

\footnotetext{
${ }^{54}$ Emmanuel já havia adiantado seu argumento em um trabalho de 1962 [Emmanuel 1971a].

55 Este é, inclusive, o título de um dos artigos de Emmanuel: "El proletariado de los países privilegiados participa en la explotación del tercer mundo" [Emmanuel 1971b].

${ }^{56}$ Além de Emmanuel e Mandel, tiveram participação destacada no debate dos anos 70 Charles Bettelheim [1972], Samir Amin [1971, 1974, 1981] e Oscar Braun [1973]. Este último propôs um tratamento em termos de preços sraffianos, o que foi aceito por Samir Amin [em Amin 1974, pp. 154-5]; para isto, introduziu o conceito de preços de produção naturais (os preços que existiriam se a taxa de lucro e a taxa de salários fossem uniformes em todo o mundo). Intercâmbio desigual consistiria, assim, na implantação e manutenção de preços de produção maiores que os "naturais” em um país e inferiores em outro [Braun 1973, p. 108]. Um
} 
de acordo com sua força produtiva; isto é necessário se queremos captar a desigualdade na própria troca; a desigualdade em termos de diferença na força produtiva do trabalho é própria à produção (cf. subseção 5.3.6).

Segundo este critério, o intercâmbio desigual tem origem nos desvios dos preços internacionais efetivos em relação aos valores - a diferença entre o preço internacional praticado e o valor internacional. O intercâmbio desigual entre países ocorrerá, então, se alguns vendem sistematicamente produtos por preços inferiores aos valores (e portanto sofrem uma perda de valor) ou compram sistematicamente por preços superiores aos valores (e portanto sofrem igualmente uma perda de valor), ou ambos, ou se uma destas perdas predomina sobre ganhos em outra direção ${ }^{57}$.

Sem pretender esgotar todas as possibilidades, são listadas abaixo as razões mais importantes para a ocorrência de intercâmbio desigual no comércio entre países menos avançados e países mais avançados. Estas razões podem combinar-se para explicar porque, para os países menos avançados, o preço de venda internacional tende a ser inferior ao valor, enquanto o preço de compra tende a ser superior.

\section{1 - Divergência entre a taxa de câmbio corrente e a taxa de câmbio em valor}

De acordo com o quadro conceitual desenvolvido aqui, a explicação mais geral das desigualdades entre preços internacionais e valores é a presença de uma diferença sistemática entre a taxa de câmbio em valor e a taxa de câmbio corrente.

Há um argumento conhecido que mostra que os níveis de preços de cada país tendem a elevar-se de acordo com o crescimento da produtividade no setor de tradables, o que provoca desvios da paridade do poder de compra. Em geral, o crescimento da produtividade no setor de non-tradables, no qual os serviços têm uma grande participação, é muito mais lento do que no setor de tradables; isto faz que a diferença entre a produtividade no

autor mais recente, Guglielmo Carchedi, discute o intercâmbio desigual e dá um lugar central à questão da taxa de câmbio. Sua proposta, no entanto, é de uma taxa de câmbio tendencial que corresponde mais a uma determinação em termos de preços de produção do que em termos de valor; cf. nota 47 deste capítulo.

${ }^{57}$ Não sendo os valores internacionais plenamente igualados, na transferência internacional de valor não há perfeita correspondência entre o que um país ganha e o outro perde. A transferência internacional de valor funciona, portanto, de modo apenas aproximado. 
setor de tradables (maior) e a produtividade no setor de non-tradables (menor) cresça quando o nível de produtividade de um país se eleva. Sendo a taxa de câmbio determinada fundamentalmente pela produtividade no setor de tradables, ela se afastará sistematicamente da taxa PPP, de uma tal maneira que, quanto maior for o nível de produtividade de um país, maior será a expressão dos preços dos seus produtos em uma moeda de referência internacional. À medida que a produtividade de um país cresce, sua taxa de câmbio tende, portanto, a se apreciar. Este fato é chamado de efeito Harrod-Balassa-Samuelson [Obstfeld and Rogoff 1996, pp. 210-4].

Traduzindo este argumento na linguagem da teoria do valor-trabalho, a vantagem da força produtiva do trabalho em um país mais avançado tecnicamente é maior para os tradables do que para os non-tradables. Se a correspondência entre as respectivas forças produtivas é estabelecida a partir dos tradables apenas - que é o que tendem a fazer as taxas de câmbio correntes -, o valor médio adicionado por hora de trabalho no país mais avançado é superestimando, e o mesmo valor no país menos avançado é subestimando.

Desta maneira, a expressão internacional do valor nacional dos produtos do país atrasado (a partir desta taxa de câmbio corrente) fica abaixo do seu valor internacional propriamente dito, isto é, do valor nacional expresso pela taxa de câmbio em valor, que reflete corretamente a diferença relativa da força produtiva média do trabalho em cada país. $\mathrm{O}$ mesmo acontece com os preços internacionais efetivos: são inferiores aos preços que corresponderiam à força produtiva do país. O mercado internacional subestima de uma forma sistemática os preços dos produtos de um país mais atrasado tecnicamente. Desta forma, ele perde valor na troca. Além da desigualdade já existente na produção (uma força produtiva menor do trabalho nacional, e portanto menor produção de valor internacional), uma desigualdade adicional é imposta na própria troca.

\section{2 - Redução adicional do valor da força de trabalho}

A partir da diferença entre a taxa de câmbio em valor e da taxa de câmbio efetiva, todos os preços do país mais atrasado tecnicamente, tal como expressos internacionalmente, ficam mais baixos do que os que corresponderiam à diferença nas forças produtivas médias do trabalho de cada país; isto acontece também para os salários. Pode acontecer, além disto, que os salários no país mais atrasado sejam ainda mais baixos. Várias razões podem explicar esta possibilidade; por exemplo, um país mais atrasado, tendo mão de obra rural em processo de expulsão do campo, pode ter um exército industrial de reserva maior. 
O rebaixamento adicional dos salários pode ser usado para aumentar a competitividade dos produtos de exportação, levando então a uma queda adicional dos seus preços, e portanto ampliando a troca desigual (venda dos produtos por preços internacionais inferiores aos valores internacionais, ou seja, à expressão internacional dos valores nacionais).

Esta é uma maneira em que a hipótese de Emmanuel (troca desigual a partir de salários mais baixos nos países dependentes) pode ser aceita; não é necessário para isto compartilhar todo seu quadro teórico (que inclui a igualação internacional das taxas de lucro, e portanto a formação de preços de produção internacionais).

\section{3 - Intercâmbio desigual a partir dos preços comerciais.}

Outro caso de intercâmbio desigual que amplia a subestimação internacional da força produtiva média do trabalho nos países tecnicamente mais atrasados decorre de margens diferentes de transferência de mais-valia para os capitais comerciais. Isto acontece se o preço de venda dos produtores - o preço de produção em sentido restrito (cf. subseção 5.3.4) - é tal que permite que os capitais comerciais dos países mais adiantados se apropriem do grosso da mais-valia, e não há uma compensação em sentido contrário (ou seja, para as mercadorias compradas pelo país mais atrasado).

A possibilidade de intercâmbio desigual a partir da desigualdade nas margens comerciais é discutida por Shaikh e Tonak [1994, pp. 66-71]. Como vimos na subseção 3.3.9 do Capítulo 3, estes autores mostram que, em geral, as diferenças entre preços e valores não são significativas. Esta afirmação, contudo, se refere na verdade à diferença entre valores, preços de mercado e preços de produção "em sentido amplo" (ou seja, preços comerciais, quando passamos a levar em conta a especialização do comércio - cf subseção 5.3.4). Para a desigualdade dos preços de produção em sentido restrito e dos preços comerciais, Shaikh e Tonak não dão nenhuma estimativa.

Ora, há uma série de dados recentes que indicam que esta diferença pode ser enorme. Michel Chossudovsky cita diversos exemplos disto; assim, uma empresa de vestuário compra uma camiseta desenhada em Paris por entre US\$3,00 e US\$4,00 em Bangladesh, no Vietnã ou na Tailândia, e a revende por um preço de cinco a dez vezes 
maior [Chossudovsky 1999, pp. 78-9] ${ }^{58}$. O livro de Naomi Klein, Sem Logo, abunda de exemplos semelhantes. E o que é mais importante: aproveitar estes tipos de ganho passou a ser uma estratégia central de diversas empresas, que mantém nos países de origem as atividades de design, marketing e centralização das vendas, e deslocam a produção para o terceiro mundo [Klein 2002].

Esta enorme desigualdade é explicada fundamentalmente pelo controle que a firma comercial (comercial no sentido de que não produz de fato suas mercadorias) exerce sobre as firmas produtoras, e sobre todo o circuito comercial.

\section{4 - Intercâmbio desigual a partir da desigualdade política}

Até aqui, tratamos do intercâmbio desigual a partir das diferenças econômicas. Naturalmente, se levamos em conta que os países tecnicamente mais avançados são também imperialistas, e os tecnicamente mais atrasados também dependentes, devemos incorporar na análise elementos mais especificamente políticos. Os países imperialistas podem forçar através de meios políticos a redução dos preços internacionais dos países dependentes, e isto amplia as possibilidades de intercâmbio desigual.

Sem pretender tratar de modo extenso deste tema, mencionemos apenas uma das maneiras em que os países dependentes têm perdido devido à sua dependência política $\mathrm{e}$ econômica. Como é amplamente conhecido, o Banco Mundial e o FMI têm imposto a diversos países que recorrem a eles as chamadas políticas de "ajuste estrutural". Uma das suas conseqüências mais comuns é a obrigação de aumentar as exportações, para pagar tanto a dívida externa quanto as maiores importações que se seguem a políticas de abertura comercial. Uma vez que estas políticas são impostas mais ou menos ao mesmo tempo para países que têm características semelhantes, levam a que muitos tentem ampliar simulta-

\footnotetext{
${ }^{58}$ Chossudovsky faz uma observação importante, enquanto comenta outro exemplo: "O preço de varejo das mercadorias produzidas no Terceiro Mundo é com freqüência até dez vezes maior que aquele pelo qual foram importadas. Desse modo, um ‘valor agregado' correspondente é criado de modo artificial dentro da economia de serviços dos países ricos, sem que ocorra nenhum tipo de produção material. Esse valor é agregado ao PIB do país rico. Por exemplo, o preço do varejo do café é sete a dez vezes mais alto do que o FOB e aproximadamente vinte vezes o pago para o produtor rural no Terceiro Mundo (ver Tabela 3.1)” [Chossudovsky 1999, p. 77]. Ou seja, o conhecido declínio do terceiro mundo no comércio mundial é, em parte, falso: é exagerado pelo fato de os fluxos comerciais oficiais não contabilizam o tipo de transferência de valor citado aqui.
} 
neamente as vendas externas dos mesmos produtos. Obviamente, isto provoca uma queda drástica dos seus preços. Susan George e Fabrizio Sabelli analisam de forma detalhada como isto aconteceu, sobretudo para países africanos, desde os anos 80 , no quadro da crise da dívida externa [George e Sabelli 1994, pp.93-113]. Michel Chossudovsky [1999] e Eric Toussaint [2002] também analisam este processo.

Esta queda dos preços por razões de política econômica constitui uma das principais variantes do intercâmbio desigual nas últimas décadas. Os preços ficam muito abaixo de seus valores. Além disso, o esforço excepcional de exportar leva a uma maior depreciação da taxa de câmbio, ampliando a perda comentada acima: além de vender muito barato, os países que são presos nesta armadilha são obrigados a comprar ainda mais caro.

\section{Conclusão: Intercâmbio desigual, ganhos e perdas no plano internacional}

Fica caracterizada, assim, a existência de amplas possibilidades de intercâmbio desigual de valor no comércio internacional, em favor dos países tecnicamente mais avançados, e em detrimento dos países tecnicamente mais atrasados.

No entanto, caracterizar a existência deste tipo de intercâmbio é apenas um dos elementos necessários para uma avaliação dos ganhos e das perdas com o comércio internacional. Outros elementos devem ser considerados, para que não fiquemos com um quadro parcial, e distorcido, do processo.

Em primeiro lugar, nem todo intercâmbio imediatamente favorável é positivo no longo prazo, e nem todo intercâmbio imediatamente desfavorável é negativo no longo prazo. O impacto de ganhos ou perdas imediatos no decorrer do tempo é muito mais complexo.

Assim, um ganho imediato no intercâmbio pode reforçar um tipo de especialização que se combina com estagnação tecnológica, e revelar-se negativo no longo prazo. Inversamente, uma perda imediata pode inserir-se no quadro de um esforço de apropriação de tecnologia, e ter seus efeitos negativos totalmente compensados no longo prazo. Uma estratégia de desenvolvimento baseada em esforço exportador, que se utilize por um período de taxas de câmbio em que a moeda nacional é muito depreciada, pode ser bem sucedida, como sabemos a partir da experiência de vários países; a condição para isto é a apropriação de tecnologia. A explicação disto está em um fato sublinhado brilhantemente por Luigi Pasinetti [1981; 1993]: a fonte fundamental de ganhos no plano internacional para os 
países atrasados tecnicamente é o aprendizado tecnológico. Os benefícios advindos do comércio (ou as perdas eventuais) são secundários; isto vale também para os ganhos a partir de vantagens comparativas, que existem sob certas condições (até porque são ganhos once and for all $^{59}$ ).

Outra observação necessária é que o aparecimento de uma perda na troca não implica obrigatoriamente que a situação tenha piorado para o país que a sofre. O exemplo mencionado no fim da subseção 5.5.1 pode ser adaptado para ilustrar este argumento. Se um país consegue introduzir inovações técnicas que reduzem o valor nacional de determinada mercadoria, e a vende no mercado internacional acima de seu valor, mas abaixo do valor que ela tem num país que a compra, estará havendo intercâmbio desigual; no entanto, o país que começa a sofrer esta perda estará em uma situação melhor do que antes: embora pague pela mercadoria mais que seu valor internacional, compra-a por um preço inferior ao que tinha de pagar por ela antes.

Assim, a análise do intercâmbio em termos de valor não é suficiente para avaliações de mudanças ao longo do tempo.

Por outro lado, os ganhos e perdas internacionais ao longo do tempo não podem ser avaliados tampouco a partir apenas da conhecida "deterioração nos termos de intercâmbio", ou dos termos de troca, apontada por Hans Singer e Raul Prebisch, embora ela tenha um caráter de comparação temporal. Nesta avaliação, no lugar de comparar quantidades de valor ou de trabalho abstrato num mesmo periodo de tempo, comparam-se quantidades físicas de produtos ao longo do tempo.

De novo, o exemplo adaptado da citação de Marx pode ilustrar este ponto. O país que teve progresso técnico e que passou a vender sua mercadoria por um preço mais baixo (embora acima de seu novo valor internacional), se a situação das mercadorias que compra não mudou, sofreu uma deterioração dos termos de troca, mas ficou numa situação duplamente melhor: pelo progresso técnico em si mesmo, e pelo ganho na troca desigual. Esta é a regra geral: quem tem progresso técnico mais rápido tende a ter deterioração de seus termos de troca, embora isto não signifique perda ${ }^{60}$. Com isto, vemos que intercâmbio desi-

\footnotetext{
59 “De uma vez por todas".

${ }^{60}$ O exemplo analisado por Obstfeld e Rogoff [1996] nas pp. 235-57 de seu livro mostra justamente isto.
} 
gual de valor e deterioração dos termos de troca podem evoluir em sentidos opostos, embora também possam andar juntos, naturalmente.

Se o problema apontado por Singer e Prebisch é de fato importante, é porque na troca de produtos primários por produtos industriais os vendedores dos primeiros deveriam ter melhora dos termos de troca, já que (em geral) o progresso técnico incide mais fortemente sobre os produtos industriais.

Vemos, portanto, que a análise dos benefícios ou prejuízos do comércio internacional é um tema complexo, do qual o intercâmbio desigual em termos de valor representa apenas um aspecto. O critério decisivo para avaliar se há ganho ou perda ao longo do tempo deve ser a evolução da magnitude dos valores de uso que podem ser obtidos a partir da hora de trabalho simples nacional ${ }^{61}$, o que depende, além do intercâmbio de valores ou dos termos de troca, da evolução da tecnologia própria ou dos parceiros comerciais. Uma avaliação mais completa da questão teria ainda de tratar ainda de temas que não foram sequer mencionados aqui - por exemplo, dos aspectos ligados ao balanço de pagamentos, das conseqüências de um possível endividamento e do volume de emprego.

Reconhecer esta complexidade, no entanto, não implica negar a importância da análise em termos de valor da desigualdade imediata no intercâmbio. Ela estabelece um fato fundamental: em geral, o país mais atrasado tecnicamente transfere valor para o mais adiantado, de forma semelhante à transferência que os setores de baixa composição orgânica do capital fazem para os de alta composição, no quadro da transformação dos valores (nacionais) em preços de produção.

Assim, o objetivo desta seção não foi fazer uma avaliação das condições em que o comércio exterior é favorável, ou avaliar estratégias de abertura econômica, questões que exigiriam uma abordagem muito mais ampla. Foi simplesmente mostrar as diversas formas assumidas pelas transferências de valor no comércio internacional e argumentar que, mesmo quando consideramos a diferença de produtividade (isto é, quando fazemos a aná-

\footnotetext{
${ }^{61}$ Isto corresponde aproximadamente ao que é chamado na literatura de termos de troca simples do fator trabalho (single factoral terms of trade para o fator trabalho). O simples aqui distingue este conceito do de double factoral terms of trade; este último, aplicado ao fator trabalho, se traduz na comparação da quantidade (concreta) de trabalho que um país recebe em troca do trabalho contido nos seus produtos.
} 
lise em termos de trabalho abstrato, normalizado internacionalmente), o intercâmbio entre países avançados e atrasados implica troca desigual de trabalho.

\subsection{5 - Um destaque: taxas de câmbio e criação de valor}

Um aspecto da análise anterior é o tratamento das taxas de câmbio como expressão da relação entre as distintas capacidades do trabalho de criar valor nos diversos países. Ou seja, as diferenças entre os países na geração e apropriação de progresso técnico, que são a causa fundamental da diferenciação na capacidade de criar valor internacional, se expressam através do seu impacto na taxa de câmbio. Afinal, se o dinheiro é a concretização material do trabalho abstrato, o valor internacional de uma moeda nacional determina a maneira pela qual o tempo de trabalho (abstrato) no país é contado internacionalmente.

Conseqüentemente, um dos objetivos fundamentais de uma política de desenvolvimento deve ser conseguir uma apreciação sustentada, de longo prazo, da moeda nacional.

\section{6 - A LEI DO VALOR NO SEU CONJUNTO E A CONCORRÊNCIA}

\section{CAPITALISTA}

Para tratar do funcionamento da lei do valor no seu conjunto, podemos partir da formulação de Ernest Mandel no segundo e no terceiro capítulos de O Capitalismo Tardio, sobre a estrutura desigual e hierarquizada do mercado mundial, seu desenvolvimento desigual e combinado e as "três fontes de superlucros". Sua ênfase está justamente na desigualdade e na hierarquia, bem como no desequilíbrio, gerados pela lei do valor. Sua conseqüência para os países atrasados é reforçar seu atraso: “(...) [A] lei do valor compele inexoravelmente os países atrasados a se especializarem, no mercado mundial, de modo desvantajoso para si próprios" [Mandel 1985, p. 49].

É explorando as conseqüências da lei do valor, e não a violando, que os países e setores mais dinâmicos buscam superlucros. Conforme o período histórico, o tipo de superlucro predominante muda. $\mathrm{Na}$ época do capitalismo de livre concorrência, o superlucro era obtido principalmente a partir da produção desigual e da transferência de valor a partir do nível distinto de produtividade nas regiões mais desenvolvidas e menos desenvolvidas ("colônias internas") no interior dos mesmos países. $\mathrm{Na}$ época do imperialismo clássico, a origem principal dos superlucros estava na relação dos países imperialistas com os países coloniais e semicoloniais; a mesma combinação de produção desigual e transferência de 
valor $^{62}$ se registrava. Finalmente, na fase do capitalismo tardio, o superlucro é obtido principalmente na justaposição de desenvolvimento em setores dinâmicos e subdesenvolvimento em outros, basicamente nos próprios países imperialistas, mas também, de modo secundário, nas semicolônias ${ }^{63}$. Estas três fontes de superlucros predominam nos distintos períodos históricos, mas não se excluem mutuamente [Mandel 1985, Capítulo 3, pp. 5173].

É possível discutir a periodização e a caracterização das distintas etapas proposta por Mandel. Seria necessário, ademais, estendê-la ao período posterior à publicação de $O$ Capitalismo Tardio. Para a discussão realizada aqui, entretanto, o importante é a idéia de que o funcionamento da lei do valor não conduz à homogeneização da economia mundial, mas à sua hierarquização permanente, com desigualdades que se modificam, sem deixarem de existir.

Para os lucros dos capitais, não importa apenas sua própria produtividade; importam as produtividades dos outros. No modelo de concorrência perfeita walrasiano, todos os agentes são tomadores de preços (price-takers), e fixam seu nível ótimo de produção selecionando a tecnologia disponível, dados seus custos e preços de venda, sem se preocuparem com o que fazem os concorrentes. No capitalismo realmente existente, ao contrário, as empresas não podem deixar de olhar para os lados. Não se trata apenas de ver nas outras empresas adversários na disputa por mercados; trata-se também de ver nas desigualdades — nacionais e internacionais — oportunidades de maiores ganhos.

A lei do valor emerge desta caracterização da economia mundial como lei da geração de superlucros, da mais-valia extra e do intercâmbio desigual.

\footnotetext{
${ }^{62}$ Mandel, a partir da sua concepção sobre a origem da mais-valia extra (subseção 5.2.3), não fala nunca em produção desigual de valor, mas apenas em transferência de valor. Como vimos na seção 5.5, as duas coisas acontecem. Para o tema desta seção esta diferença com a abordagem de Mandel não é importante.

${ }^{63}$ Em O Capitalismo Tardio o termo semicolônia é usado para os países dependentes em geral.
} 


\section{CAPÍtulo 6 - Conclusão: As CATEgorias da ECONOMIA MARXISTA DIANTE DE OUTRAS ABORDAGENS}

\section{1 - INTRODUÇÃo}

Este capítulo faz uma série de comparações entre a abordagem de Marx e outras abordagens, com o objetivo de chamar a atenção para duas questões: a de como a economia de Marx pode reivindicar alguns pontos-fortes em comparação com outras abordagens teóricas, e a de como vários deles se relacionam diretamente com o duplo caráter do trabalho (e das categorias da economia capitalista em geral) e com a concepção do valor como substância social. Complementa, portanto, observações que foram feitas ao longo deste trabalho ${ }^{1}$.

As comparações com outras abordagens não pretendem, de nenhuma maneira, representar uma análise crítica das suas contribuições. Seu objetivo é muito mais o de, através do contraste, chamar a atenção para características da abordagem de Marx.

Por outro lado, argumentamos também que a teoria do valor e as categorias da economia marxista, tal como interpretadas aqui, são um bom ponto de partida para o desenvolvimento da ciência econômica.

\section{2 - MERCADORIA, DINHEIRO E CAPITAL}

\subsection{1 - Duplo caráter do trabalho, substância do valor e dinheiro}

A concepção da mercadoria como constituída de dois contrários — valor de uso e valor - , e como resultado de um trabalho que se desdobra em trabalho concreto e trabalho abstrato, reflete teoricamente de maneira bastante adequada a natureza da economia capitalista. A noção de que a generalização das relações mercantis dá origem a uma substância socialmente constituída, o trabalho abstrato, que se objetiva como valor das mercadorias, base para as comparações entre as diversas mercadorias, pode ser considerada mais realista do que a idéia de que uma economia que produz mercadorias de forma generalizada pode

\footnotetext{
${ }^{1}$ Especialmente na seção 1.5 do Capítulo 1.
} 
ser compreendida como um processo de trocas em que cada agente procura avaliar qual coleção de bens, dentre as inúmeras possibilidades existentes, lhe daria maior utilidade (representação que constitui o quadro de referência fundamental da economia neoclássica).

Além disto, da primeira concepção o dinheiro nasce naturalmente, como representação material desta substância social, como figura geral do valor; é uma necessidade teórica e prática ${ }^{2}$. Já para a segunda concepção a explicação do estatuto do dinheiro torna-se um quebra-cabeça. Assim, comparando os dois quadros teóricos, o da economia de Marx e o neoclássico (na sua versão walrasiana), chegamos naturalmente a uma explicação da origem da dificuldade da teoria neoclássica para tratar do dinheiro (e a fortiori do capital): o problema fundamental está em como compreende a própria natureza da economia que se propõe a estudar. Em uma palavra, ela não pensa estar estudando uma economia cuja marca distintiva é a produção de mercadorias: unidades (contraditórias) de valor de uso e valor. Ao se focar sobre os bens entendidos como meros valores de uso, desconhece a dimensão do valor (como conteúdo distinto do valor de troca).

O modelo básico da economia neoclássica é, aliás, pelo menos em sua versão "mais rigorosa", walrasiana, o modelo de uma pura "economia de trocas", em que não há produção. A produção é introduzida em um momento posterior, e é essencialmente concebida como troca, isto é, troca de insumos (incluindo os "serviços dos fatores de produção") por produtos. Seu conceito de valor é de valor relativo, preço relativo (não há preços monetários ou preços absolutos). Portanto, pura proporção de troca. Não há nenhuma substância do valor (o que, aliás, certamente seria considerado pelos modernos neoclássicos como uma categoria metafísica). Os valores só podem ser os resultados de um sistema de equações de equilíbrio. Esta é a única maneira de determiná-lo quantitativamente; sem o conceito de equilíbrio, o valor seria inteiramente indeterminado, pois um bem poderia ser trocado por outro em qualquer proporção.

Examinando mais detalhadamente esta ausência de uma substância do valor, vemos que a troca na concepção neoclássica não supõe uma igualação de algum aspecto do bem; um agente troca se obtiver com isto maior utilidade. Não se supõe a igualdade de utilida-

\footnotetext{
${ }^{2}$ Uma economia mercantil exige, como vimos neste trabalho, a constituição de uma representação geral da riqueza; para que haja produção de mercadorias, tem de haver dinheiro. O dinheiro concebido desta maneira não é evidentemente nem um simples numerário, nem um simples intermediário das trocas.
} 
des, e muito menos a redução das distintas utilidades individuais a uma utilidade geral, comum, "abstrata", para falar como Marx (o que seria necessário para poder falar de utilidades iguais). Aliás, isto nem seria possível, pois a utilidade está sempre ligada a um corpo material, a um valor de uso particular; além disso, sendo um conceito subjetivo, é incomensurável entre os agentes.

Não pode haver, tampouco, redução de trabalho concreto a trabalho abstrato. Tanto os bens (ou serviços) trocados, quanto o trabalho que os produz, são irremediavelmente heterogêneos. Aliás, os bens não são fundamentalmente percebidos como produzidos pelo trabalho. Na formulação inicial da teoria do equilíbrio geral, de uma economia de trocas, os agentes recebem dotações de bens e trocam seus excessos. Quando a produção é introduzida no modelo, e se admite a produção para a troca, isto não leva a uma caracterização distinta da nova natureza dos bens; não se pensa que pode haver uma alteração fundamental na sua natureza, ou seja, não se pensa que bens produzidos para a troca sejam mercadorias, e que isto é diferente de simples bens em geral. Em toda esta construção teórica, não há constituição de uma substância social (o trabalho abstrato) que torna a mercadoria contraditória e o dinheiro sua representação necessária.

Os bens, portanto, não são mercadorias para os neoclássicos. Não são portadores de valor. Se para Marx o valor só se manifesta na relação entre dois bens (no caso, duas mercadorias), mas já existe em cada mercadoria (na medida em que esta é um produto do trabalho humano, feito intencionalmente e de forma regular para a troca), para os neoclássicos, sequer faz sentido falar do valor de um bem fora da relação de troca. A questão não é que o valor só se manifeste na equiparação de dois bens, ou na troca: ele simplesmente não existe fora dela. $\mathrm{O}$ valor como tal não existe; há apenas valor de troca. Para Marx, a proporção em que as mercadorias se trocam é determinada em primeiro lugar pelo seu valor que, com o processo de generalização da produção para a venda, existe desde o momento da própria produção, antes portanto da troca. Para os neoclássicos, a proporção em que os bens se trocam é determinada exclusivamente pelas condições da própria troca (refletindo as dotações e as preferências dos agentes, bem como as tecnologias existentes, quando há produção). Se para Marx, como o valor existe antes da troca (ou da venda), o preço realmente obtido pode ser distinto dele, para os neoclássicos a distinção entre preço e valor não 
faz nenhum sentido. Mesmo a definição de preços normais ou naturais, importante para os primeiros neoclássicos, foi abandonada pelos neoclássicos mais recentes ${ }^{3}$.

Esta concepção dos neoclássicos, de que os bens não são portadores de valor, não são mercadorias, isto é, não são fundamentalmente produzidos para a troca (e portanto produzidos), se explica porque não vêem nenhuma diferença significativa entre uma "economia de trocas" sem produção, uma economia com produção mas que desenvolve apenas a troca direta, o escambo, e a economia mercantil, pelo menos no que diz respeito à natureza dos bens. Já mencionamos que a produção é essencialmente concebida como uma troca. Além disto, uma economia de trocas generalizadas é concebida como não tendo uma diferença qualitativa com relação a uma economia de trocas eventuais. Elas difeririam apenas quantitativamente ${ }^{4}$. Isto é, uma economia em que os bens não são em geral produzidos para a troca, em que se trocam apenas seus excessos, e uma economia em que os bens no conjunto são produzidos para a troca, e em que portanto as trocas são generalizadas, só seriam distintas porque a segunda é mais complexa do que a primeira.

Assim, o quadro teórico neoclássico, especialmente na sua vertente walrasiana, é totalmente inadequado para compreender especificidade da mercadoria. Não se compreende que uma mercadoria não é qualquer produto do trabalho humano, e menos ainda um bem não produzido. Uma mercadoria é um bem produzido para ser vendido; no contexto da economia capitalista, essa é a forma geral que assumem os produtos do trabalho.

Caracterizando uma economia de escambo, Marx diz em Para a Crítica da Economia Política:

\footnotetext{
${ }^{3}$ A este respeito, o artigo de Garegnani [1976] é esclarecedor.

${ }^{4}$ Isto se comprova pelo costume extremamente curioso da economia neoclássica de começar estudando seus problemas em economias “com dois participantes” (quando não com um único indivíduo, que é o único consumidor e detém a única firma) para depois tentar generalizar, aumentando o número de participantes. Quando a generalização não é possível, considera-se que é pelas complicações práticas ou técnicas, e não pela natureza essencialmente diferente das duas economias. Se partimos da concepção bem desenvolvida por Marx, de que as duas economias são qualitativamente diferentes, fica fácil entender porque estes procedimentos típicos da teoria neoclássica não podem funcionar. Aliás, a estranheza destes procedimentos só é superada pela bizarria de começar estudando "economias sem produção".
} 
O comércio à base de troca direta, forma natural do processo de troca, apresenta muito mais a transformação incipiente dos valores de uso em mercadorias do que a das mercadorias em dinheiro. Aqui o valor de troca não reveste uma figura livre, mas está ainda vinculado imediatamente ao valor de uso. Isto se revela de duas maneiras. A própria produção, em toda a sua estrutura, está dirigida a valores de uso e não a valores de troca, e por isso somente através da formação de um excedente sobre a quantidade de valores de uso necessária ao consumo é que os valores de uso deixam de ser valores de uso para serem meios de troca, isto é, mercadoria. Por outro lado, tornam-se propriamente mercadorias apenas dentro dos limites do valor de uso imediato, se bem que distribuídos polarmente de tal maneira que as mercadorias, que devem ser intercambiadas pelos seus possuidores, precisam ser valor de uso para ambos, mas cada qual para aquele que não a possui [Para a Crítica $d a$ Economia Política, pp. 45-6].

O mesmo tema é retomado em O Capital [O Capital I-I, pp. 81-2; El Capital I-I, p. 107]. Não é um exagero dizer que a concepção neoclássica básica da economia corresponde muito mais a esta descrição de uma economia de trocas diretas do que a uma economia capitalista.

É interessante notar que também Keynes, nos seus escritos preparatórios à Teoria Geral, dá à questão da distinção entre uma economia de escambo e uma economia monetária um lugar central na crítica à teoria neoclássica (ou "clássica", como ele prefere):

A distinção que é normalmente feita entre uma economia de escambo e uma economia monetária depende do emprego do dinheiro como um meio conveniente para realizar trocas como um instrumento de grande conveniência, mas transitório e neutro nos seus efeitos (...). Não se supõe que ele afete a natureza essencial das transações e que elas deixem de se fazer, nas mentes dos que as fazem, entre coisas reais, ou modifique os motivos e decisões das partes. O dinheiro, desta maneira, é empregado, mas é tratado como sendo em certo sentido neutro.

A teoria que desejo diria respeito, ao contrário desta, a uma economia na qual o dinheiro joga um papel próprio e afeta os motivos e decisões e é, em suma, um dos fatores operativos da situação, de tal maneira que o curso dos eventos não pode ser previsto, seja no longo prazo ou no curto, sem um conhecimento do comportamento do dinheiro entre o primeiro estágio e o último. E é isto que queremos dizer quando falamos de uma economia monetária [The Collected Writings of John Maynard Keynes, London, Macmillan and Cambridge, Cambridge University Press, 1971-1989, vol. XIII, p. 408-409, apud Carvalho 1992, p. 37]. 
Na verdade, Keynes chega a caracterizar que a economia em que os postulados dos “clássicos" se aplicam só pode ser uma "economia cooperativa" ou uma "economia neutra". Uma economia cooperativa é aquela em que:

(...) $[\mathrm{O}] \mathrm{s}$ fatores de produção são recompensados pela divisão do produto real de seus esforços cooperativos segundo proporções acertadas [Keynes 1971-89, vol. XXIX, apud Rotheim 1981, p. 575].

Ou seja, os "fatores de produção" são pagos diretamente com bens. Nesta economia os postulados da "economia clássica" valem obrigatoriamente. Valeriam também em uma "economia neutra", que seria

(...) [U]ma sociedade do tipo daquela em que de fato vivemos, onde o funcionamento do processo produtivo depende amplamente de uma classe de empresários que alugam os fatores de produção por dinheiro e buscam seu pagamento vendendo o produto por dinheiro, com a condição de que os rendimentos correntes dos fatores de produção são necessariamente gastos, direta ou indiretamente, com a compra de seu próprio produto corrente dos empresários [Keynes 1971-89, vol. XXIX, p. 77, apud Rotheim 1981, p. 576].

O autor pós-keynesiano Fernando Cardim de Carvalho diz a respeito deste tipo de economia:

Esta concepção de economia, que Minsky apelidou de "paradigma da feira de aldeia" ("village fair paradigm"), a vê como constituída por consumidores-produtores independentes que comerciam os excedentes de sua produção que ultrapassam suas necessidades [Carvalho 1992, p. 39].

Ou seja, tanto Keynes (nos seus escritos preparatórios à Teoria Geral — na própria Teoria Geral estas idéias não apareceram tão claramente) quanto autores pós-keynesianos fazem uma caracterização da concepção de economia dos neoclássicos muito semelhante à que pode ser construída a partir de Marx ${ }^{5}$.

É interessante registrar que há uma segunda razão que afasta o modelo walrasiano, ou neowalrasiano, do equilíbrio geral, de uma economia capitalista. Com sua ficção (necessária dentro da sua lógica) do "leiloeiro", que centraliza todas as trocas, só permitindo

\footnotetext{
${ }^{5}$ Outros aspectos do tratamento que os pós-keynesianos (e o próprio Keynes) dão à necessidade do dinheiro apresentam mais diferenças com relação ao argumento de Marx. Um ponto chave é o da finalidade da produção, ao qual voltaremos abaixo.
} 
que elas se façam quando se atinge o vetor de preços de equilíbrio; com sua definição de que todos os preços dos mesmos bens são obrigatoriamente iguais (anunciados pelo leiloeiro), com suas suposições de perfeita informação para todos os agentes, ele é de fato o modelo de uma economia ultracentralizada ${ }^{6}$. Esta necessidade de, contrariamente à sua intenção de "modelar" uma economia descentralizada, chegar à máxima centralização, tem uma relação muito clara com o fato de não conceber a economia que teoriza como uma economia de produção de mercadorias e, portanto, com não atribuir um papel central ao dinheiro. Podemos entender esta centralização das trocas e dos preços no leiloeiro, ao lado da exigência de só permitir as trocas no equilíbrio, como uma tentativa de evitar as contradições próprias à troca real das mercadorias, em que estas não obrigatoriamente conseguirão ser vendidas, em que o trabalho privado não é sempre reconhecido como social, etc.

Uma terceira razão que afasta o modelo de economia dos neoclássicos de uma economia capitalista é que nele o objetivo da economia é o consumo, ou melhor, a maximização das utilidades, e não a acumulação da riqueza abstrata. Voltaremos a este ponto na próxima subseção deste capítulo.

Há uma razão mais geral para a incapacidade da economia neoclássica de tratar adequadamente a economia mercantil e o dinheiro. Sua incapacidade de compreender a diferença dos bens em uma "economia sem produção", em uma economia com produção mas que só realiza trocas na forma de escambo, e uma economia mercantil, em que as mercadorias são, na sua a imensa maioria, produtos do trabalho, produzidos de forma intencional e regular para a troca (venda), liga-se, naturalmente, à sua recusa à dialética, e mais especificamente à sua recusa a compreender as mercadorias como objetos contraditórios, unidades de valor de uso e de valor. Por isto não ela apenas não trata adequadamente do dinheiro nos modelos já desenvolvidos até agora; não pode superar esta limitação drástica, a não ser que mude radicalmente sua concepção teórica ${ }^{7}$.

Como vimos anteriormente, há uma mudança qualitativa, fundamental, na passagem de uma economia de trocas eventuais para uma economia mercantil, e isto se traduz diretamente na necessidade do dinheiro. A generalização das trocas - a formação de uma

\footnotetext{
${ }^{6}$ Este ponto é destacado por Bernard Guerrien [1989].

${ }^{7}$ Este impossibilidade é um dos temas centrais da tese de Leda Paulani [Paulani 1991].
} 
economia mercantil - significa, antes de qualquer coisa, transformar os bens (produtos do trabalho) em mercadorias; acrescentar-lhes ao lado do seu valor de uso, um caráter de valor; ao mesmo tempo atribuir ao trabalho de produzi-los, ao lado do seu caráter específico, concreto, e privado, o caráter de trabalho abstrato, e social. As mercadorias, portanto, são objetos profundamente contraditórios.

Para concluir: a economia capitalista é antes de tudo uma economia produtora de mercadorias, e uma característica fundamental da mercadoria é a de ser portadora de valor, unidade de valor de uso e valor. O dinheiro, que é o desenvolvimento, a autonomização, a exteriorização, a materialização da dimensão de valor, está portanto presente desde o início. Isto não acontece para os neoclássicos; o valor como tal não está presente, e não marca portanto toda a lógica da produção. O dinheiro tem de ser introduzido depois que as características fundamentais da economia já foram estabelecidas, quando ela por assim dizer já está funcionando, e por isto ele não encontra seu lugar ${ }^{8}$. Fica mais difícil incluir o dinheiro "de forma essencial", como se queixava Frank Hahn".

\subsection{2 - Capital e dinâmica}

Outro ponto forte da economia de Marx é o conceito de capital. A idéia do capital como uma substância semovente, representada privilegiadamente pelo dinheiro, que se expande através das suas metamorfoses, a partir de uma determinada estrutura de relações sociais, reflete bem melhor o caráter real do capital na economia capitalista do que a dis-

\footnotetext{
${ }^{8}$ Como Alfredo Saad-Filho e Costas Lapavitsas observam: "Para Marx, a moeda, enquanto equivalente geral, tem um papel especial na reprodução econômica. A moeda se origina a partir do caráter essencial da mercadoria, que é o de requisitar a troca com outra mercadoria com um valor de uso diferente. Isto transforma a outra mercadoria na forma equivalente do valor, a qual pode ser diretamente trocada pela primeira. O desenvolvimento e generalização desta relação explica a monopolização das trocas diretas por uma mercadoria específica, que se torna moeda. Em contraste, a teoria neoclássica presume ex ante que as mercadorias são trocadas diretamente, e em seguida tenta derivar a moeda como meio de troca. Este procedimento é logicamente falho porque, se as mercadorias podem ser trocadas diretamente, a moeda não pode ter nenhuma propriedade que a diferencie delas" (Saad-Filho, Alfredo, e Lapavitsas, Costas: "A Teoria Horizontalista da Moeda e do Crédito: Uma Análise Crítica”, Estudos Econômicos, Vol.29, nº 1, 1999, pp.33-34).

${ }^{9}$ Em diversos trabalhos [Hahn 1965; 1973; 1975], Hahn tratou da dificuldade da economia neoclássica de incorporar o estudo do dinheiro; cf. nota 51 do Capítulo 1.
} 
solução deste conceito numa coleção de bens de capital. Como se sabe, a vinculação entre bens de capital heterogêneos e montantes de valor, na estrutura teórica neoclássica, não consegue evitar raciocínios circulares ${ }^{10}$. Por outro lado, a substância semovente de Marx inclui como seus momentos tanto coleções de bens de capital quanto o capital-dinheiro (e, de quebra, inclui ainda o capital-mercadorias, cuja existência é difícil de negar, e que não encontra um estatuto claro na economia neoclássica).

Há ainda uma vantagem importante das categorias de Marx mencionadas, que é a de abrirem o caminho para uma melhor compreensão da dinâmica da economia capitalista. A idéia de um conjunto de relações sociais de interdependência que se resumem no capital como um sujeito automático dominante, cujo objetivo impessoal é a expansão do valor, isto é, da riqueza abstrata, tem mais poder explicativo do que a concepção do capital como insumos utilizados para uma produção de bens cujo objetivo é a maximização de utilidades.

Compreender que a finalidade que move a economia capitalista é a produção de valor, e não de valores de uso, que é a valorização do capital que determina sua dinâmica, é indispensável para a apreensão da natureza do capital, e portanto do próprio dinheiro — já que poder transforma-se em capital é uma das suas determinações. Neste ponto, é interessante retomar a comparação com a economia keynesiana, comentando brevemente a evolução do pensamento de Keynes a este respeito na preparação da Teoria Geral.

Inicialmente, Keynes chegou a valorizar a fórmula marxista da circulação do capital, $D-M-D$ '; posteriormente, seguiu um outro caminho. Como Leda Paulani [Paulani 1991, pp. 83-97] argumenta: Keynes, na Teoria Geral, não conseguiu corresponder às possibilidades que sua visão intuitiva, manifestada enquanto preparava seu livro, abria para a percepção da natureza da economia capitalista. Ora,

(...) $[\mathrm{O}]$ que diferencia a economia monetária na qual vivemos, por exemplo, da economia empresarial neutra, é a finalidade da produção e não a existência ou não de dinheiro, visto que ele também existe nesta última [Paulani 1991, p. 86].

A limitação da formulação na Teoria Geral se revela na sua comparação com a visão intuitiva anterior:

\footnotetext{
${ }^{10}$ Este foi um dos temas centrais da controvérsia do capital nos anos 50, 60 e 70 do século XX.
} 
Assim, se, na visão, Keynes intuía o papel fundamental e diferenciado do dinheiro a partir de sua percepção quanto à motivação que comanda o processo capitalista, na teoria é o dinheiro, de per $s i$, que vai constituir o ponto de partida, e não porque seja ele o padrão de valor, mas simplesmente em função se suas 'peculiaridades técnicas' (elasticidades de produção, substituição, etc.) [Paulani 1991, p. 94].

Retomando a questão das limitações da economia neoclássica, é importante observar que no tratamento do capital a carência de uma compreensão dialética da realidade é decisiva. A economia neoclássica não compreende seu objeto de estudo como economia capitalista, isto é, como uma economia em que são produzidas mercadorias e na qual a finalidade é a valorização do capital. Não pode explicar de forma coerente o que é o dinheiro e que papel ele cumpre. Ora, como a discussão da tendência ao entesouramento e da passagem do dinheiro ao capital mostra, o capital só pode ser entendido a partir da tendência a superar a circulação simples (a fórmula $M-D-M$ ) e a assumir a circulação na forma $D-M-D^{\prime}$ que o dinheiro adquire (uma vez que as relações mercantis se generalizam). A necessidade de pensar o processo como um desenvolvimento contraditório aparece com toda clareza. Se a exclusão da contradição do campo de visão da economia neoclássica já impede a compreensão da mercadoria e do dinheiro, com muito mais razão impede a compreensão do capital, com suas metamorfoses permanentes.

É interessante chamar a atenção para um outro aspecto de toda esta discussão. Tanto as dificuldades da economia neoclássica em relação ao dinheiro (especialmente nos modelos walrasianos) quanto no tratamento do capital (evidenciada nas várias controvérsias sobre o capital, não apenas na realizada sobretudo nos anos 50, 60 e 70 do século XX) são bem conhecidas. Contudo, a profunda ligação entre estas duas dificuldades não é em geral percebida. Do ponto de vista da teoria de Marx, ela fica muito clara.

Examinando a evolução do tratamento da economia neoclássica do capital a partir da controvérsia sobre o capital dos anos 50, 60 e 70, vemos que uma das conseqüências desta controvérsia foi o abandono, pelo menos nos textos teóricos com pretensão de rigor, de uma visão do capital como a de John Bates Clark. Este autor distingue capital e bens de capital:

Podemos pensar no capital como uma soma de riqueza produtiva, investida em coisas materiais que estão mudando perpetuamente - que vêm e vão continuamente - embora o fundo permaneça. O capital então vive, por assim dizer, por transmigração, saindo dos corpos e entrando em outros, de novo e de novo [Clark 1899, pp. 119-20]. 
Com esta concepção, como é bem sabido, Clark queria justificar o lucro pela produtividade marginal do capital. Mas não foi por esta razão que ela foi abandonada pela teoria neoclássica com pretensões de rigor ${ }^{11}$. Foi abandonada fundamentalmente a partir das dificuldades de agregação de bens de capital heterogêneos em um único capital definido macroeconomicamente. Não é aqui, é claro, o lugar para avaliar se tal abandono foi bem justificado. Mas vale a pena observar que esta concepção de um capital que "transmigra", saindo de uns corpos e entrando em outros, aproxima-se de certa forma da idéia das metamorfoses do capital de Marx. Além disto, corresponde bastante a certos aspectos do funcionamento real de uma economia capitalista: é verdade que o capital, enquanto fundo de valor, assume várias formas; tanto é dinheiro, como determinado estoque de "bens de capital", como mercadorias produzidas que serão vendidas.

A diferença fundamental entre a concepção de Clark e a de Marx é que aquele não concebe o capital como fundo de valor, mas como fundo (palavra que tem relação com substância) de capacidade produtiva (ele diz "soma de riqueza produtiva"). Para Marx, como vimos, o capital como substância é valor, relação social, manifestação do caráter peculiar do trabalho que produz mercadorias; de modo algum "capacidade" ou "força produtiva”. O valor de um estoque de capital pode mudar se a capacidade produtiva dos meios de produção em que ele está investido não se altera (por exemplo, se há progresso técnico na produção das máquinas que o compõem). Ou, inversamente, coleções de "bens de capital" com capacidade produtiva muito diferente podem ter o mesmo valor (e transferir para as mercadorias produzidas o mesmo valor).

Se a capacidade produtiva é uma propriedade dos valores de uso, a remuneração do capital, por outro lado, diz respeito às propriedades sociais do capital, ao capital enquanto valor.

Portanto, do nosso ponto de vista, o erro da concepção de Clark está na própria concepção de capital como capacidade produtiva, está em desconhecer o duplo caráter do trabalho produtor de mercadorias e todos os seus desdobramentos ${ }^{12}$. Não está na agrega-

\footnotetext{
11 Nas “versões populares” ela continua tão presente como antes.

12 Thorstein Veblen, ao criticar a concepção de Clark do capital como um fundo que permanece transmigrando, disse o seguinte: "Falar de uma transferência de 'capital' que não envolve uma transferência de 'bens de capital' é uma contradição com a posição fundamental, de que o 'capital' é constituído de 'bens de capi-
} 
ção dos bens de capital, e nem na idéia de um fundo dotado da faculdade de "transmigração"! Sem pretender opinar sobre qual é a melhor maneira de tratar o capital no contexto neoclássico, podemos dizer que a questão da agregação ou da desagregação pouca diferença faz ${ }^{13}$.

Para quem quer reproduzir na teoria o funcionamento real de uma economia capitalista, isto é, para quem quer compreender o que é capital, o "maior rigor" atual da teoria neoclássica - em que o conceito de capital é evitado, e subsistem apenas bens de capital — é certamente pior do que a falta de rigor de John Bates Clark.

A concepção do capital como conjunto de bens de capital é compartilhada pela economia sraffiana. Em Produção de Mercadorias por Meio de Mercadorias, Sraffa explicita que uma das características básicas de sua abordagem é evitar qualquer idéia de quantidade de capital medida independentemente dos preços:

(...) [O] termo "capital" em sua conotação quantitativa [foi evitado], às custas de algum cansativo circunlóquio. Isso porque esses termos [Sraffa refere-se, além do termo "capital", ao termo "custos de produção" - JM] acabaram ficando ligados inseparavelmente à suposição de que representam quantidades que podem ser medidas independentemente e antes da determinação dos preços dos produtos. (Recordem-se dos "custos reais" de Marshall e da "quantidade de capital" implícita na teoria de produtividade marginal.) Visto que um

tal'. O continuum no qual a 'entidade permanente' do capital reside é uma continuidade de propriedade, não um fato físico. A continuidade, na verdade, é de uma natureza imaterial, uma questão de direitos legais, de contrato, de compra e venda" [Veblen 1972 (1908), p. 181]. É possível dizer que Veblen tocou de uma maneira distinta no ponto argumentado aqui: Clark misturou os aspectos físicos do capital (como a produtividade) com os aspectos de valor (que são sociais, se expressam legalmente, têm uma natureza imaterial).

13 Também os críticos sraffianos têm dito que a questão da desagregação não elimina as inconsistências do tratamento que a economia neoclássica dá ao capital, e isto desde o trabalho de Garegnani de 1970 [Garegnani 1970]. Entre os trabalhos mais recentes que insistem neste ponto incluem-se: Schefold [1997; 2000]; Petri [1998; 1999]; Garegnani [2000]. Os economistas neoclássicos têm ignorado estes trabalhos; desinteressaram-se das controvérsias sobre o capital e não respondem mais aos seus críticos. A propósito deste fato, Duncan Foley, em um artigo-resenha de Mongiovi e Petri (eds.) [1999], faz uma observação extremamente sugestiva: "De fato, dado o interesse decrescente no equilíbrio geral entre os teóricos do maisnstream, eu suspeito que a maior parte do esforço original a respeito do equilíbrio geral nos últimos dez anos pode ter sido despendido por seus críticos clássicos” [Foley 2001, pp. 378-9]. 
dos objetivos deste trabalho consiste em libertar-se de tais pressupostos, a eliminação dos termos pareceu ser o único modo de não prejudicar o tema [Sraffa 1985, p. 183].

Para Sraffa, a redução do capital a um conjunto de bens (de mercadorias, mais exatamente) pode ser entendida como uma maneira provisória de caracterizá-lo, necessária no contexto de uma crítica à teoria neoclássica. De fato, Produção de Mercadorias por Meio de Mercadorias tem um objetivo fundamentalmente crítico (lembremos que o subtítulo do seu livro é "Prelúdio a uma crítica da teoria econômica", onde "teoria econômica" refere-se à economia neoclássica), e não apresenta uma teoria completa do funcionamento de uma economia capitalista. No entanto, quando os economistas referenciados em sua obra definiram sua abordagem da economia capitalista - a chamada abordagem do excedente (surplus approach _ - , mantiveram este tratamento do capital. Como lemos, por exemplo, em um trabalho de um dos mais destacados sraffianos, Pierangelo Garegnani (referindo-se à necessidade, compartilhada pelo surplus approach e pela economia neoclássica, de medir o capital de modo independente da distribuição):

$\mathrm{Na}$ abordagem clássica [Garegnani refere-se ao surplus approach - JM], o capital pode afinal ser medido como um conjunto de magnitudes (quantidades físicas dos vários meios de produção, ou quantidades de 'trabalho datado'), permitindo então uma solução do problema. Como veremos, a mesma maneira de medir põe dificuldades básicas nas teorias marginalistas [Garegnani 1990, p. 2].

A possibilidade de prescindir de um conceito de capital distinto dos bens de capital, e de quantificá-lo, é desta forma apresentada como uma vantagem da abordagem do excedente.

Do ponto de vista da abordagem defendida neste trabalho, o enfoque do capital defendido por Garegnani é uma deficiência. O surplus approach fica privado da possibilidade de tratar do capital como valor que se valoriza, como substância em movimento, e perde com isto uma dimensão essencial da economia capitalista.

Contudo, a abordagem sraffiana evita o erro mais grave da teoria neoclássica, que é confundir o capital com a capacidade produtiva dos meios de produção. Na verdade, faz mais que isto: critica enfaticamente este erro da economia neoclássica. Ao demonstrar que as variáveis de distribuição (a taxa de lucro e os salários) são determinadas fora do seu sistema de equações (que representa as proporções em que determinadas quantidades físicas de mercadorias produzem outras quantidades de mercadorias), Sraffa provou também 
que a remuneração do capital não é determinada pela produtividade física (com o mesmo sistema de equações, e portanto com a mesma produtividade física, a taxa de lucro pode variar de zero até uma taxa máxima chamada de $R$ ). Ou seja, o capital não pode ser entendido como capacidade produtiva.

Retomamos aqui, então, a mesma consideração feita no Capítulo 4, seção 4.5, com relação à abordagem sraffiana: ela pode ser incorporada como um aspecto da economia marxista. Os sistemas de equações desenvolvidos em Produção de Mercadorias por Meio de Mercadorias representam as proporções em que certas quantidades físicas de mercadorias podem ser usadas para produzir outras quantidades físicas de mercadorias, determinam a partir daí os limites da variação da taxa de lucro e dos salários (em um quadro de equilíbrio entre oferta e demanda e de preços estacionários), e determinam ainda os limites em que, nas mesmas condições, os preços estacionários podem variar. Estas equações devem ser consideradas um instrumento analítico extremamente útil: certamente não são suficientes para reproduzir conceitualmente o funcionamento de uma economia capitalista, mas expressam algumas de suas características. Neste sentido, são semelhantes aos esquemas de reprodução de Marx.

\subsection{3 - A determinação dos salários}

Vimos, no Capítulo 5, subseção 5.2.5, que Luigi Pasinetti, em Structural Change and Economic Growth, enfatiza o caráter macroeconômico dos salários de uma maneira essencialmente semelhante à que realizamos aqui, embora a partir de um quadro teórico distinto do que está sendo exposto neste trabalho. Podemos compartilhar também a contraposição que ele realiza entre esta concepção e a da abordagem neoclássica:

A 'taxa de salário real' da teoria econômica tradicional relaciona-se com a produtividade marginal do trabalho. É um único número - um número de unidades físicas da mercadoria que é produzida no setor em que o trabalhador está realmente trabalhando. Mas este não é o conceito da taxa de salário real que é relevante em um sistema econômico moderno. Quando o grau de especialização na produção é muito marcado, o conceito de 'taxa de salário real' que se torna relevante é representado, não por um único número, mas por todo um conjunto de números (um vetor), indicando a cesta física de bens nos quais a taxa de salário é realmente gasta, e, como tal, dependente na produtividade física do sistema econômico como um todo [Pasinetti 1981, p. 137]. 
Naturalmente, a idéia de que os salários reais são determinados pela produtividade marginal do trabalho pode ser contestada por outras razões. Mas o ponto posto em relevo aqui é fundamental e se relaciona, como vimos na subseção 5.2.5, com o duplo caráter do trabalho e a interação do trabalho abstrato e do trabalho concreto. Enquanto a produtividade do trabalho (média ou marginal) é uma característica do trabalho concreto individual, os salários reais dependem da interação do valor da força de trabalho (e portanto de um quantum de trabalho abstrato) com a produtividade geral do trabalho na economia (característica do trabalho concreto no conjunto da economia).

\subsection{4 - Diferenças entre preços e valores}

Na subseção 1.5.3 do Capítulo 1 chamamos a atenção para o fato de que a abordagem marxista da economia é a única que dá uma importância central à distinção entre preços e valores, e à possibilidade de que os primeiros se desviem dos segundos. Este tema esteve presente também nos Capítulos 4 e, sobretudo, 5; neste último, destacamos a importância do conceito de troca desigual como troca desigual de valor, baseada portanto nestes desvios.

O sentido da diferença entre preços e valores está ligado à concepção do valor como uma substância que se objetiva em diversas formas possíveis, e que pode assumir magnitudes diferentes. O valor não é uma simples relação de troca.

Esta concepção tem uma outra grande vantagem, já mencionada no Capítulo 4, seção 4.5: permite o tratamento de situações de não equilibrio. Nestas situações, os preços não podem ser determinados como solução de um sistema de equações em que oferta e demanda se igualam. Aí a noção de uma existência de uma substância do valor é indispensável, como explicam Freeman e Carchedi:

Precisamente porque os conceitos de equilíbrio não podem dar uma fundamentação teórica para a economia de não-equilíbrio, uma ruptura coerente com o Equilíbrio Geral é impossível sem uma teoria do valor.

Isto fica claro logo que se façam as perguntas mais simples: por exemplo, se as pessoas compram e vendem a preços de não-equilíbrio, o que acumulam? (...)

(...) Igualem-se ou não oferta e demanda, os capitais trocam e acumulam valor: trabalho pretérito. Uma economista ou um economista que não pode dar esta resposta é como um físico privado da energia; ela ou ele não tem um conceito genérico com o qual explicar in- 
terações entre sistemas heterogêneos. Tudo tem de ser estudado isoladamente de tudo o mais [Freeman e Carchedi 1996a, pp. XII-XIII].

\section{3 - O DUPlo CARÁter do TRABAlHo E AS CONTRAdiÇÕES DO}

\section{CAPITALISMO}

\subsection{1 - O caráter contraditório do progresso técnico}

Na seção 3.2 do Capítulo 3 chamamos a tenção para a importância do duplo caráter do trabalho na economia capitalista e dos seus desdobramentos. Destacamos aqui, como vantagens especialmente importantes da abordagem marxista, apenas alguns aspectos relacionados com as contradições da economia capitalista.

Em primeiro lugar: o progresso técnico tem uma relação extremamente contraditória com a economia capitalista. De um lado, ele é extremamente estimulado por ela; introduzir inovações técnicas é em geral um objetivo de qualquer empresa capitalista. Isto se deve à concorrência intra-setorial (Capítulo 5, subseção 5.2.4).

O impacto geral da introdução do progresso técnico, no entanto, não é simplesmente positivo; em muitos aspectos, é até negativo. Progresso técnico amplia a capacidade de produzir valores de uso, e portanto amplia a riqueza material; mas não amplia a produção de valor (exceto quando se restringe a uma parte das empresas, de modo transitório), e só aumenta os lucros de quem se coloca à frente na corrida, resultado que é logo questionado $^{14}$. No longo prazo, além disso, provoca uma tendência à elevação da composição orgânica do capital e a partir daí uma tendência à queda da taxa de lucro ${ }^{15}$.

A curto ou médio prazo, a introdução do progresso técnico tende a provocar superprodução; esta é uma das conseqüências da concorrência intra-setorial. A razão disto é clara: a introdução de inovações técnicas quase sempre exige produção em maior escala, e os que ampliam a sua produção ficam obrigados a deslocar os concorrentes, a disputar-lhes

\footnotetext{
${ }^{14}$ Como vimos no Capítulo 5.

${ }^{15} \mathrm{O}$ estudo deste importante desdobramento da interação contraditória entre o trabalho concreto e o trabalho abstrato ultrapassa os limites deste trabalho.
} 
o mercado. A introdução de progresso técnico a partir da concorrência não pode ser feita, é claro, de modo planejado, com o cuidado de evitar superprodução.

Em suma, o progresso técnico não pode em geral evitar as crises da economia capitalista; ao contrário, pode mesmo precipitá-las. A economia marxista explica de forma perfeitamente clara este ponto: esta é uma decorrência do duplo caráter do trabalho, da distinção entre riqueza física e riqueza abstrata (em valor). Certamente outras abordagens teóricas - inclusive a neoclássica — tratam eventualmente da distinção entre riqueza material e valor. Mas é possível argumentar que as categorias de Marx são as que a fazem de maneira mais consistente. Não há dúvida de que esta distinção é decisiva para explicar as crises da economia capitalista desenvolvida, e para explicar um dos paradoxos do século XX e deste início de século XXI: o enorme progresso técnico não levou ao que seria de se esperar, isto é, uma grande redução da miséria, para não falar da sua completa eliminação, nem mesmo nos países capitalistas mais ricos.

$\mathrm{Na}$ verdade, a economia neoclássica, em especial, não tem meios teóricos para tratar da divergência entre produção material e produção de valor; seu quadro teórico, ao fazer da economia capitalista uma economia voltada para a produção de valores de uso, e não para a valorização do capital, retira a importância desta questão.

\subsection{2 - A precariedade da mão invisível do mercado}

O duplo caráter do trabalho e da riqueza é a chave para entendermos porque, ao contrário das esperanças que muitos depositam na auto-regulação da economia pelo mercado, os resultados disto têm sido sempre muito precários.

O objetivo capitalista da produção é o valor, a valorização do capital, e não a produção de valores de uso para satisfazer necessidades humanas. Para produzir uma mercadoria, uma empresa deve ser motivada pelo lucro que obterá daí.

Isto não é nenhuma novidade; Adam Smith já o compreendia muito bem.

Não é da benevolência do açougueiro, do cervejeiro ou do padeiro que esperamos nosso jantar, mas da consideração que eles têm pelo seu próprio interesse. Dirigimo-nos não à sua humanidade, mas à sua auto-estima, e nunca lhes falamos das nossas próprias necessidades, mas das vantagens que advirão para eles [Smith 1983, p. 50]. 
(...) $[\mathrm{M}]$ as se alguém emprega um capital para fomentar a atividade, assim o faz exclusivamente em função do lucro; conseqüentemente, sempre se empenhará no sentido de aplicar este capital no fomento daquela atividade cujo produto é suscetível de atingir o valor máximo, isto é, daquele produto que possa ser trocado pela quantidade máxima de dinheiro ou de outras mercadorias [Smith 1983, p. 379].

Não há nada a objetar quanto a esta compreensão do funcionamento do mercado. O problema é a conclusão otimista que Smith extrai destas considerações:

Ora, a renda anual de cada sociedade é sempre exatamente igual ao valor de troca da produção total anual da sua atividade (...). Portanto, já que cada indivíduo procura, na medida do possível, empregar seu capital em fomentar a atividade nacional e dirigir de tal maneira essa atividade que seu produto tenha o máximo valor possível, cada indivíduo necessariamente se esforça por aumentar ao máximo possível a renda anual da sociedade. Geralmente, na realidade, ele não tenciona promover o interesse público nem sabe até que ponto o está promovendo. Ao preferir aumentar a atividade do país e não de outros países, ele tem em vista apenas sua própria segurança; e orientando sua atividade de tal maneira que sua produção possa ser de maior valor, visa apenas seu próprio ganho e, neste, como em muitos outros casos, é levado como que por mão invisível a promover um objetivo que não fazia parte de suas intenções. Ao perseguir seus próprios interesses, o indivíduo muitas vezes promove o interesse da sociedade muito mais eficazmente do que quando tenciona realmente promovê-lo. Nunca ouvi dizer que tenham realizado grandes coisas para o país aqueles que simulam exercer o comércio visando ao bem público [Smith 1983, pp. 379-80].

Muitos foram os autores que mostraram que nem sempre a mão invisivel promove o interesse da sociedade de modo tão eficaz como Smith imaginava. Do ponto de vista deste trabalho, interessa chamar a atenção para um aspecto apenas: em todo este raciocínio, Smith desconhece o duplo caráter do trabalho e a contradição entre riqueza material e riqueza abstrata (valor). As contradições decorrentes daí (em particular as contradições da lei do valor, a dinâmica da concorrência intra-setorial, os efeitos contraditórios do progresso) mostram que a mão invisível funciona muito precariamente, e sofre um problema de fundo: é irracional buscar o máximo de bem-estar (material) pela maximização do lucro (valor).

\section{4 - UM QUADRO TEÓRICO REALISTA, COERENTE, AMPLO E}

\section{FLEXÍVEL}


Uma última observação diz respeito ao quadro teórico da economia marxista e as demais abordagens.

Argumentamos ao longo deste trabalho que as categorias da economia marxista reproduzem adequadamente características fundamentais da economia capitalista; e que, além disto, seu quadro teórico é coerente. Em particular, mostramos que a crítica mais importante à sua consistência lógica — a afirmação de que é impossível transformar valores em preços de produção de modo compatível com a teoria do valor — não tem validade.

Acrescentamos aqui apenas mais um argumento em favor deste quadro teórico: sua maior amplitude, quando comparado aos demais. Ao destacar o duplo caráter das categorias fundamentais da economia capitalista e, portanto, ao interessar-se tanto pela análise no plano material, físico, quanto em termos de valor e das relações sociais, a economia marxista vai além de outras abordagens, e torna possível incluí-las no seu arcabouço, ou incluir aspectos de suas análises. Uma abordagem feita estritamente em termos materiais, de valores de uso, por outro lado, não pode incluir no seu interior aspectos fundamentais das análises marxistas. Do mesmo modo, ao atribuir um lugar central à especificidade histórica da economia capitalista, a economia marxista vai além de outras abordagens: tanto pode estudar a lógica específica da economia capitalista, quanto ir além dela, mostrar seus limites.

Não se segue daí, obviamente, que a economia marxista possa incluir qualquer análise feita a partir de outras vertentes teóricas ${ }^{16}$. O ponto é apenas que, tendo um quadro teórico mais amplo e flexível, ela tem maior capacidade de servir de ponto de partida para integrar outras abordagens.

Podemos concluir este trabalho acreditando ter cumprido um dos seus objetivos fundamentais: argumentar que as categorias econômicas de Marx são um bom ponto de partida para a compreensão da economia capitalista - possívelmente o melhor dentre as alternativas existentes. Esta avaliação se justifica pelas características de seu quadro teórico: realista, coerente, amplo e flexível.

\footnotetext{
${ }^{16}$ Em alguns casos, as possibilidades de integração são muito grandes, como acontece com as análises sraffianas, ou com as vertentes pós-keynesianas que destacam o caráter de economia monetária da produção da economia capitalista. Em outros, são muito menores - no caso da economia neoclássica, o grande complicador é, como vimos, que esta escola representa a economia capitalista de uma forma muito distante do capitalismo realmente existente.
} 


\section{BIBLIOGRAFIA}

Amin, Samir (1971). L'Accumulation à l'Échelle Mondiale. Paris, Éditions Anthropos.

(1974). El Desarrollo Desigual. Barcelona, Editorial Fontanella. Originalmente publicado em francês, em 1973.

(1981). L’Échange Inégal et la Loi de la Valeur. Paris, Éditions Anthropos, 2 ème édition. Edição original em francês de 1973.

Arthur, Christopher J. (ed.) (1996). Engels Today. A Centenary Appreciation. London, Macmillan.

Arthur, Christopher J. (1996). "Engels as Interpreter of Marx’s Economics”. In: Arthur (ed.) 1996, pp. 173-209.

(1998). “Engels, Logic and History”. In: Bellofiore, Riccardo (ed.) 1998a, pp. 3-15.

Backhaus, Hans Georg (1974). "Dialectique de la forme de la valeur", Critiques de l'Économie Politique $\mathrm{n}^{\circ}$ 18, octobre-décembre, pp. 5-33. Originalmente publicado em alemão em 1969.

Banaji, Jairus (1979). "From the Commodity to Capital: Hegel's Dialectic in Marx's Capital". In: Elson, Diane (ed.) 1979, pp. 14-45.

Bellofiore, Riccardo (ed.) (1998a). Marxian Economics: A Reappraisal. Essays on Volume III of Capital. Volume 1: Method, Value and Money. London, Macmillan.

(1998b). Marxian Economics: A Reappraisal. Essays on Volume III of Capital. Volume I1: Profits, Prices and Dynamics. London, Macmillan.

Bettelheim, Charles (1972). “Observações teóricas". In: Emmanuel (1972), pp. 305-58. Originalmente publicado em francês, em 1969.

Böhm-Bawerk, Eugen von (1974): "La Conclusión del Sistema de Marx", in Sweezy, Paul (1974b), pp. 29-127. Originalmente publicado em alemão em 1896.

Böhm-Bawerk, Eugen von (1986). Capital e interés. México, Fondo de Cultura Económica, 2a edição em espanhol. Obra publicada pela primeira vez em alemão, em 1884.

Burkett, Paul (1991). "Some Comments on 'Capital in General and the Structure of Marx's Capital". Capital and Class 44, Summer, pp. 49-72.

Bortkiewicz, Ladislaus von (1952): "Value and Price in the Marxian System". International Economic Papers, 1952 (2), pp. 5-60. Originalmente publicado em alemão em 1906-1907. 
(1974): “Contribución a una retificación de los fundamentos de la construción teórica de Marx en el volumen III de El Capital", in Sweezy, Paul (1974a), pp. 191-213. Originalmente publicado em alemão em 1907.

Braun, Oscar (1973). Comercio Internacional e Imperialismo. Buenos Aires, Siglo Veintiuno Editores de Argentina.

Brown, M., Sato, K. And Zarembka, P. (eds.) (1976). Essays in Modern Capital Theory. Amsterdam, North Holland.

Carcanholo, Reinaldo (1991). "O valor, a riqueza e a teoria de Smith". Análise Econômica, 9 (15), março, pp. 183-205.

(1996): Valor e Preço de Produção. Universidade Federal do Espírito Santo, Cadernos de Economia ${ }^{\circ}$ 11. Originalmente publicado em espanhol em 1977.

(2000). "Sobre o conceito de mais-valia extra". Anais do V Encontro Nacional de Economia Política, Fortaleza.

Carchedi, Guglielmo (1991): Frontiers of Political Economy. London, Verso.

(1996): "Non-equilibrium market prices", in Freeman and Carchedi (eds.) (1996), pp. 164-182.

Carchedi, Guglielmo and de Haan, Werner (1996): "The transformation procedure: a nonequilibrium approach", in Freeman and Carchedi (1996), pp. 136-163.

Castoriadis, Cornelius (1987). "Valor, Igualdade, Justiça, Política. De Marx a Aristóteles e de Aristóteles até Nós", in As Encruzilhadas do Labirinto, I. Paz e Terra, pp. 264-335. O artigo foi publicado originalmente em francês em 1975; republicado em livro (Les Carrefours du Labyrinthe, Seuil) em 1978.

Cartelier, Jean (1981). Excedente y Reproducción. México, Fondo de Cultura Económica. A edição original francesa, é de 1976.

Carvalho, Fernando J. Cardim (1992). Mr. Keynes and the Post Keynesians. Aldershot, England, Edward Elgar.

Chossudovsky, Michel (1999). A Globalização da Pobreza. São Paulo, Moderna. Originalmente publicado em inglês, em 1997.

Clark, John Bates (1899): The Distribution of Wealth. New York, Augustus M. Kelley Bookseller, 1965 (reprodução da edição original de 1899).

Colletti, Lucio (1974). "Bernstein et le marxisme de la Deuxième Internationale", in Colletti, Lucio, De Rousseau a Lenine. Paris, Gordon \& Breach, pp. 101-174. 
Dobb, Maurice (1945). Economía Política y Capitalismo. México, Fondo de Cultura Económica. Publicado originalmente em inglês, em 1937.

Teoria del Valor y de la Distribución desde Adam Smith. Buenos Aires, Siglo XXI Argentina, 1975. Edição original em inglês de 1973.

Dostaler, Gilles et Laguex, Maurice (dir.) (1985). Un échiquier centennaire. Théorie de la valeur et formation des prix. Paris et Québec, Éditions La Découverte et Presses Universitaires du Québec.

Dunne, Paul (ed.) (1991). Quantitative Marxism. Cambridge (UK), Polity Press.

Eatwell, John and Milgate, Murray (eds.) (1983). Keynes's Economics and the Theory of Value and Distribution. Oxford, Duckworth.

Eatwell, John, Milgate, Murray and Newman, Peter (eds.) (1990a). The New Palgrave - Marxian Economics. London, Macmillan, and New York, W.W. Norton. O dicionário The New Palgrave foi originalmente publicado em 1987.

Eatwell, John, Milgate, Murray and Newman, Peter (eds.) (1990b). The New Palgrave - Capital Theory. London, Macmillan, and New York, W.W. Norton. O dicionário The New Palgrave foi originalmente publicado em 1987.

Echeverria, Rafael (1978). “Critique of Marx's 1857 Introduction”. Economy and Society, Vol. 7 (4), November, pp. 333-366.

Echeverria, Rafael (1980). "The concrete and the abstract in Marx's Method - a reply to Terrel Carver". Economy and Society, Vol. 9 (2), May, pp. 204-217.

Eldred, Michael (1994a): “A Reply to Gleicher”, in Mohun, Simon (ed.) (1994), pp. 199-203. Originalmente publicado em 1984. (1994b): “Postscript” a 1994a, pp. 203-204.

Eldred, Michael, and Hanlon, Marnie (1981): "Reconstructing Value-Form Analysis". Capital and Class n. ${ }^{\circ}$ 13, Spring, pp. 24-60.

Elson, Diane (ed.) (1979). Value: The Representation of Labour in Capitalism. London, CSE Books.

Elson, Diane (1979). “The Value Theory of Labour”. In: Elson, Diane (ed.) 1979, pp. 115-80.

Emmanuel, Arghiri (1971a). "El intercambio desigual". In: Emmanuel y otros (1971), pp. 5-37. Artigo originalmente publicado em 1962. 
(1971). "El proletariado de los países privilegiados participa en la explotación del tercer mundo". In: Emmanuel y otros (1971), pp. 164-9.

(1972). El intercambio desigual. México, Siglo Veintiuno Editores. Originalmente publicado, em francês, em 1969.

Emmanuel y otros (1971). Imperialismo y Comercio Internacional. (El intercambio desigual). Buenos Aires, Cuadernos Pasado y Presente, $n^{\circ} 24$.

Engels, Friedrich (1976). "La ley del valor y la tasa de ganancia”. In: Marx, Karl, 1976c, pp. 112647.

Faccarello, Gilbert (1998). "Some Reflections on Marx's Theory of Value", in Bellofiore (ed.) 1998a, pp. 29-47.

Fausto, Ruy (1983a). Marx — Lógica e Politica, Tomo I. São Paulo, Editora Brasiliense.

(1983b). “Dialética Marxista, Humanismo, Anti-humanismo". In: Fausto, 1983a, pp. 2765

(1983c). “Abstração Real e Contradição: sobre o Trabalho Abstrato e o Valor". In: Fausto, 1983a, pp. 89-138. Artigo publicado originalmente em francês, em 1978.

(1983d). “Circulação de Mercadorias, Produção Capitalista”. In: Fausto, 1983a, pp. 141223.

(1987a). Marx - Lógica e Política, Tomo II. São Paulo, Editora Brasiliense.

(1987b). "Pressuposição e posição: dialética e significações 'obscuras"”. In: Fausto 1987a, pp. 149-98.

(1997). Dialética Marxista, Dialética Hegeliana: A Produção Capitalista como Circulação Simples. São Paulo, Editora Paz e Terra, Editora Brasiliense.

Foley, Duncan K. (1982). "The Value of Money, the Value of Labor-Power and the Marxian Transformation Problem". The Review of Radical Political Economics, Vol. 12, n 2, Summer, pp. 37-47.

(2001). "Value, Distribution and Capital: a Review Essay". Review of Radical Political Economics, volume 13, number 3, July.

Freeman, Alan. (1995): "Marx without equilibrium". Capital and Class n. ${ }^{\circ}$ 56, Summer, pp. 49-89. (1996a): "The psicopathology of Walrasian Marxism", in Freeman and Carchedi (eds.) 1996, pp.1-28. 
(1996b): "Price, value and profit - a continuous, general, treatment", in Freeman and Carchedi (eds.) 1996, pp. 225-279.

(1998). "The Limits of Ricardian Value: Law, Contingency and Motion in Economics", na sua página na Internet.

Freeman, Alan and Carchedi, Guglielmo (eds.) (1996). Marx and Non-Equilibrium Economics. Cheltenham, UK and Brookfield, US, Edward Elgar. (1996a): "Foreword", in Freeman and Carchedi (eds.) 1996, pp. VII-XX. (1996b): "Introduction", in Freeman and Carchedi (eds.) 1996, pp. XXI-XXVI.

Garegnani, Pierangelo y otros (1979): Debate sobre la teoría marxista del valor. México, Ediciones de Pasado y Presente.

Garegnani, Pierangelo (1970). "Heterogeneous Capital, the Production Function and the Theory of Distribution". In: Review of Economic Studies, vol. 37, pp. 407-36. Republicado em Hunt and Schwartz (eds.) 1972, pp. 245-291.

(1976). "On a Change in the Notion of Equilibrium in Recent Work on Value: a Comment on Samuelson”. In: Brown, Sato and Zarembka (eds.) 1976. Republicado em Eatwell and Milgate (eds.) 1983.

(1979). “La realidad de la explotación”. In: Garegnani y otros (1979), pp. 30-64. Originalmente publicado em italiano, em 1978. (1990). "Quantity of Capital". In: Eatwell, John, Milgate, Murray and Newman, Peter (eds.) (1990b), pp. 1-78.

(2000). "Savings, investment and capital in a system of general intertemporal equilibrium”. In: Kurz, Heinz (ed.) 2000, pp. 392-449

George, Susan, et Sabelli, Fabrizio (1994). Crédits sans Frontières. La religion séculière de la Banque mondiale. Paris, La Découverte.

Geras, Norman (1971). "Essence and Appearance: Aspects of Fetishism in Marx's Capital". New Left Review 65, January-February, pp. 69-85.

Germer, Claus (1998). "O conceito de 'padrão-ouro' e os equívocos da Economia Política”. Niterói, Anais do III Econtro Nacional de Economia Política.

Gleicher, David (1983). "A historical approach to the question of abstract labour". Capital and Class 21, Winter, pp. 97-122. Republicado em Mohun (ed.) 1994, pp. 174-198. 
Grossmann, Henryk (1975). Marx, l'Economie Politique Classique et le Problème de la Dynamique. Paris, Editions Champ Libre. Publicação original, em alemão, em 1940.

(1979). "Modificación del Plan Originario de la Estructura de 'El Capital' de Marx y sus Causas". In": Grossmann, Henrik. Ensayos sobre la Teoría de las Crisis. Dialéctica y Metodología en "El Capital". México, Ediciones Pasado y Presente, pp. 41-70. Publicação original, em alemão, em 1929.

Guerrien, Bernard (1989). La Théorie Néo-classique. Bilan et Perspectives du Modèle d'équilibre général. Paris, Economica, 3eme édition.

Hahn, Frank (1965): "On Some Problems of Proving the Existence of Equilibrium in a Monetary Economy", in Hahn and Brechling (eds.) The Theory of Interest Rates, London, Macmillan; republicado em Hahn Equilibrium and Macroeconomics, Cambridge, Massachusetts, The MIT Press, 1984.

(1973): "On the Foundations of Monetary Theory", in Parkin and Nobay (eds.) Essays in Modern Economics, Manchester, Longman Group. Republicado em Hahn [1984].

(1975): "Money and General Equilibrium", Indian Economic Journal, 23, oct-dec. Republicado em Hahn Money, Growth and Stability, Oxford, Basil Blackwell, 1985.

Harvey, Philip (1985). "The Value-Creating Capacity of Skilled Labor in Marxian Economics". Review of Radical Political Economics 17:1/2 (Spring/Summer), pp.83-102.

Hegel, G.W.F. (1968). Ciencia de la Lógica. Buenos Aires, Ediciones Solar y Librería Hachette.

(1970a). Précis de l'Encyclopédie des Sciences Philosophiques. Paris, Librairie Philosophique J. Vrin.

(1970b). Encyclopédie des Sciences Philosophiques, I, La Science de la Logique, § 33, $3^{a}$ édition, 1830, tradução francesa e notas de Bernard Bourgeois. Librairie Philosophique J. Vrin, Paris.

Heinrich, Michael (1989). "Capital in general and the structure of Marx's Capital". Capital and Class 38, Summer 1989, pp. 63-79.

Hilferding, Rudolf (1974). "La crítica de Böhm-Bawerk a Marx", in: Sweezy (org.), 1974. Originalmente publicado em alemão, em 1904.

Hodgson, Geoff (1974): "Marxian Epistemology and the Transformation Problem". Economy and Society $\mathrm{n}^{\circ} 3$ (4), November, pp. 357-392.

Horverak, Øyvind (1988). "Marx's view of competition and price determination". History of Political Economy, vol. 20, nº 2, Summer, pp. 275-297. 
Hunt, E. K. and Schwartz, Jesse G. (eds.) (1972). A Critique of Economic Theory. Harmondsworth, Penguin Books.

Itoh, Makoto and Yokokawa, Nobuharu (1979). “Marx's Theory of Market Value”. In: Elson (ed.) 1979, pp. 102-114.

Itoh, Makoto (1980). Value and Crisis. New York, Monthly Review Press, 1980. (1988). The Basic Theory of Capitalism. The Forms and Substance of the Capitalist Economy. Totowa, New Jersey, Barnes \& Noble Books, 1988.

Kay, Geoffrey (1979). "Why Labour is the Starting Point of Capital”. In: Elson, Diane (ed.) 1979, pp. 46-66.

Kliman, Andrew (1998). "Value, Exchange-Value and the Internal Consistency of Volume III of Capital: A Refutation of Refutations". In: Bellofiore (ed.) 1998b, pp. 29-42.

Kliman, Andrew, and McGlone, Ted (1988): "The Transformation non-Problem and the nonTransformation Problem". Capital and Class n. ${ }^{\circ}$ 35, Summer, pp. 56-83.

Kliman, Andrew, and McGlone, Ted (1999). “A Temporal Single-system Interpretation of Marx's Value Theory". Review of Political Economy, volume 11, number 1, January.

Klein, Naomi (2002). Sem Logo. A Tirania das Marcas em um Planeta Vendido. Rio de Janeiro, Editora Record. Originalmente publicado em inglês, em 2000.

Kurz, Heinz D. (ed.) (2000). Critical Essays on Piero Sraffa's Legacy in Economics. Cambridge, Cambridge University Press.

Lagueux, Maurice (1985). "Le principe de conservation et le problème de la transformation". In Dostaler e Lagueux (org.), Un échiquier centenaire, La Découverte, 1985, pp. 107-25.

Lebowitz, Michael A (1992). Beyond Capital. Marx's Political Economy of the Working Class. New York, St. Martin's Press.

Lenin, Vladimir Illitch Ulianov (1972). Cuadernos Filosóficos. Buenos Aires, Ediciones Estudio. Redigido entre 1895 e 1916.

Likitkijsomboon, Pichit (1995): "Marxian Theories of Value-Form". Review of Radical Political Economics, Vol. 27, nº 2, pp. 73-105.

Lipietz, Alain (1982): “The So-Called 'Transformation Problem' Revisited”. Journal of Economic Theory, Vol. 26 (1), February, pp. 59-88.

(1983). Le monde enchanté: De la valeur à l'envol inflationniste. Paris, La Découverte/Maspero. 
Lippi, Marco (1979a). Marx. El valor como coste social real. Madrid, Ediciones Piramide. Originalmente publicado em italiano em 1976.

(1979b). "A lei do valor-trabalho como 'forma' da lei geral da produção: um reexame". In: Lippi 1979a, pp. 155-168. Texto de uma apresentação oral realizada em 1978. (1979c): "El principio del valor-trabajo", in Garegnani y otros (1979), pp. 84-94.

Maldonado-Filho, Eduardo (1987): “A transformação dos valores em preços de produção e o fenômeno da absorção e liberação de capitais". Anais do XV Encontro Nacional de Economia, Salvador.

Mandel, Ernest (1967). La formation de la pensée économique de Karl Marx. Paris, François Maspero.

(1976). "Introduction". In: Marx 1976b, pp. 11-88.

(1981). “Introduction”. In: Marx 1981, pp. 9-90.

(1985). O Capitalismo Tardio. São Paulo, Nova Cultural, $2^{a}$ edição, 1985. Originalmente publicado em alemão em 1972.

Mandel, Ernest and Freeman, Alan (eds.) (1984). Ricardo, Marx, Sraffa. London, Verso.

Marx, Karl (1965). Oeuvres Economie I, Bibliothèque de la Pléiade, Paris, Gallimard. (1965b). Misère de la Philosophie. In: Karl Marx, Oeuvres Economie I, 1965, pp. 1-136. (1965c). Le Capital. In: Karl Marx, Oeuvres Economie I, 1965, pp. 535-1406.

(1968). Oeuvres Economie II, Bibliothèque de la Pléiade, Paris, Gallimard.

(1971a). Das Kapital, Erster Band. Berlin, Dietz Verlag.

(1971b, 1972, 1976a): Elementos Fundamentales para la crítica de la economia política (borrador) 1857-1858 (Obra em geral conhecida pelo seu nome em alemão, Grundrisse). México, Siglo Veintiuno Editores. Três volumes: Volume I, 1971; Volume II, 1972; Volume III, 1976.

(1971c). Introducción General a la Crítica de la Economía Política / 1857. In: Marx, Karl (1971b), pp. 1-33.

(1973). Grundrisse. London, Penguin Books.

(1975a). Das Kapital. Dritter Band. Berlin, Dietz Verlag, 1975.

(1975b). El Capital, Libro Primero. Volúmenes I, II e III. Buenos Aires, Siglo Veintiuno Argentina Editores. 
(1976b). Capital, Volume 1. London, Penguin Books.

(1976c). El Capital. Libro Tercero. Volúmenes VI, VII e VIII. México, Siglo Veintiuno

Editores, 1976.

(1981). Capital, Volume 3. London, Penguin Books.

(1982a). Para a Crítica da Economia Política. São Paulo, Abril Cultural, Os Economistas.

(1982b). Introdução à Crítica da Economia Política (1857). In Marx, Karl (1982a), pp.

$3-21$.

(1982c). Salário, Preço e Lucro. In Marx, Karl (1982a), pp. 133-185.

(1982d) Notas Marginales al Tratado de Economía Política de Adolph Wagner. México,

Ediciones Pasado y Presente.

(1987, 1983, 1985). Teorias da Mais-Valia. São Paulo, Difel. Três volumes: Volume I, Segunda Edição, 1987; Volume II, 1983; Volume III, 1985.

(1988). Economic Manuscript of 1861-1863, volume I. In Karl Marx and Frederick

Engels, Collected Works, Volume 30. New York, International Publishers.

(1989). Economic Manuscript of 1861-1863, volume III. In Karl Marx and Frederick

Engels, Collected Works, Volume 32. New York, International Publishers.

(1988). O Capital. São Paulo, Nova Cultural, $3^{\text {a }}$ edição. Cinco volumes: Livro I, Volumes I e II; Livro II, Volume III; Livro III, Volumes IV e V.

(1989). Economic Manuscript of 1861-1863, volume III. In Karl Marx and Frederick Engels, Collected Works, Volume 32. New York, International Publishers.

(sem data). Capitulo VI Inédito de O Capital. Resultados do Processo de Produção Imediata. São Paulo, Editora Moraes.

Marx, Karl, et Engels, Friedrich (1964): Lettres sur “Le Capital”. Paris, Éditions Sociales.

McGlone, Ted and Kliman, Andrew (1996): "One system or two? The transformation of values into prices of production versus the transformation problem", in Freeman and Carchedi (eds.) (1996), pp. 29-48.

Meek, Ronald (1973). Studies in the Labour Theory of Value. London, Lawrence \& Wishart, Second Edition. A primeira edição é de 1956.

(1971a). Economia e Ideologia. Rio de Janeiro, Zahar Editores. Edição original inglesa de 1967. 
(1971b) “Sraffa e a Reabilitação da Economia Clássica”. In: Meek 1971a, pp. 209-230.

Mirowski, Philip (1989). More Heat than Light. New York, Cambridge University Press.

Mohun, Simon (ed.) (1994). Debates in Value Theory. London, Macmillan Press Ltd.

Mohun, Simon (1994). “Value, Value-Form and Money”. In: Mohun (ed.) 1994, pp. 214-230.

Mongiovi, Gary, and Petri, Fabio (eds.) (1999). Value, Distribution and Capital. Essays in honour of Pierangelo Garegnani. London, Routledge.

Morishima, Michio e Catephores, George (1980). Valor, Exploração e Crescimento. Rio de Janeiro, Zahar Editores. Originalmente publicado em inglês em 1978.

Fred Moseley (ed.) (1993). Marx's Method in Capital - A Reexamination. New Jersey, Humanities Press International.

Moseley, Fred (1991). The Falling Rate of Profit in the Postwar United States Economy. London, Macmillan,

(1993a): "Introduction”, in Moseley, Fred (ed.), 1993a, pp. 1-13.

(1993b): "Marx's Logical Method and the 'Transformation Problem"”, in Moseley, Fred (ed.) (1993), pp. 157-183.

(1995). "Capital in General and Marx’s Logical Method: A Response to Heinrich's Critique". Capital and Class 56, Summer 1995, pp. 15-48.

(1998). "Marx's Logic in Capital and the 'Transformation Problem"”. In: Bellofiore (ed.) 1998b, pp. 14-28.

(2000). "The 'New Solution' to the Transformation Problem: A Sympathetic Critique". Review of Radical Political Economics, Vol. 32 (2), pp. 282-316.

(2001). "The development of Marx's theory of the distribution of surplus-value in the Manuscript of 1861-63”. Review of Radical Political Economics, Vol. 33 (3), Summer 2001, pp. 265-271.

(2001-2). "Marx’s logical error: a comment". Science and Society, Vol. 65 (4), Winter 2001-2, pp. 515-527.

Naples, Michele (1996): "Time, money, equilibrium: methodology and the labour theory of the profit rate", in Freeman and Carchedi (eds.) 1996, pp. 95-115.

Nicolaus, Martin (1973). "Foreword". In: Marx 1973.

Oakley, Allen (1983). The Making of Marx's Critical Theory - A Bibliographical Analysis. London, Routledge \& Kegan Paul. 
Obstfeld, Maurice and Rogoff, Kenneth (1996). Foundations of International Macroeconomics. Cambridge, Massachusetts, The MIT Press.

Pasinetti, Luigi (1981). Structural Change and Economic Growth. Cambridge, Cambridge University Press.

(1993). Structural Economic Dynamis. A theory of the economic consequences of human learning. Cambridge (UK), Cambridge University Press.

Paulani, Leda (1991). Do Conceito de Dinheiro e do Dinheiro como Conceito. Tese de Doutorado. São Paulo, FEA-USP.

Petri, Fabio (1998). "The 'Sraffian' critique of neoclassical economics: some recent developments". Revista da Sociedade Brasileira de Economia Política, ${ }^{\circ}$ 3, dezembro, pp. $5-44$.

(1999). "Professor Hahn on the 'neo-Ricardian' criticism of neoclassical economics". In: Mongiovi, Gary and Petri, Fabio (eds.), pp. 19-68.

Postone, Moishe (1978). "Necessity, Labor, and Time: A Reinterpretation of the Marxian Critique of Capitalism". Social Research, Vol. 45 (4), winter 1978, pp. 739-788. In: Wood 1988c, pp. 546-577.

Time, labor and social domination. New York, Cambridge University Press, 1993.

Roberts, Bruce (1987). "Marx after Steedman: Separating Marxism from 'Surplus Theory"”. Capital and Class n. ${ }^{\circ}$ 32, Summer, pp. 84-103.

Ramos-Martínez, Alejandro and Rodríguez-Herrera, Adolfo (1996): "The transformation of values into prices of production: a different reading of Marx's text", in Freeman and Carchedi (eds.) 1996, pp. 49-76.

Reati, Angelo (1989). "A Note on the Alleged Redundancy of Labor Value". Review of Radical Political Economics, Vol. 21, n 1-2, pp. 169-174.

Reuten, Geert (1993). "The Difficult Labor of a Theory of Social Value: Metaphors and Systematic Dialectics at the Beginning of Marx's Capital”, in Moseley, Fred (ed.) (1993), pp. 89-113. (1995): "Conceptual Collapses - A Note on Value-Form Theory". Review of Radical Political Economics, Vol. 27, nº 3, pp. 104-110.

Reuten, Geert and Williams, Michael (1989): Value-Form and the State. London, Routledge.

Rodríguez-Herrera, Adolfo (1996): "Money, the postulates of invariance and the transformation of Marx into Ricardo". In Freeman and Carchedi 1996 (eds.), pp. 77-94. 
Rosdolsky, Roman (2001). Gênese e Estrutura de O Capital de Karl Marx. Rio de Janeiro, Contraponto Editora/Editora da UERJ. Originalmente publicado em alemão em 1968.

Rotheim, Roy J. (1981): “Keynes' monetary theory of value (1933)”. Journal of Post Keynesian Economics, Vol. III, № 4, Summer, pp. 568-585.

Rowthorn, Robert (1982). "Trabalho Qualificado no Sistema Marxista”. In: Capitalismo, Conflito e Inflação, Zahar Editores. Publicado originalmente como artigo em 1973.

Rubel, Maximilien (1968). “Introduction”. In: Marx 1968, pp. XVII-CXXVII.

Rubin, Isaak Illich (1974). Ensayos Sobre la Teoria Marxista del Valor. Buenos Aires, Ediciones Pasado y Presente, Siglo XXI Argentina. Traduzido da 3ª edição russa, de 1928.

(1980). A Teoria Marxista do Valor. São Paulo, Brasiliense. Traduzido da $3^{\text {a }}$ edição russa, de 1928.

(1994). “Abstract Labour and Value in Marx’s System”, in Mohun, Simon (1994), pp. 35-72. Originalmente publicado em 1927.

Saad-Filho, Alfredo (1997). "Concrete and Abstract Labour in Marx's Theory of Value". Review of Political Economy, Vol. 9 (4), October 1997, pp. 457-477.

Saad-Filho, Alfredo, e Lapavitsas, Costas (1999): “A Teoria Horizontalista da Moeda e do Crédito: Uma Análise Crítica”. Estudos Econômicos, IPE-USP, São Paulo, Vol. 29, nº 1.

Salama, Pierre. Sur la Valeur (1975). Paris, Librairie François Maspero.

Salama, Pierre et Tran Hai Hac (1992). Introduction à l'économie de Marx. Paris, La Découverte.

Samuelson, Paul A. (1970). “The 'Transformation' from Marxian 'Values' to Competitive 'Prices': A Process of Rejection and Replacement". Proceedings of the National Academy of Sciences, U.S.A., vol.67, № 1, September, pp. 423-425.

(1971). "Understanding the Marxian Notion of Exploitation: A Summary of the SoCalled Transformation Problem Between Marxian Values and Competitive Prices". The Journal of Economic Literature, vol. IX, No 2, June, pp.399-431.

Schefold, Bertram (1997a). Normal Prices, Technical Change and Accumulation. London, Macmillan.

(1997b). "Classical Theory and Intertemporal Equilibrium". In: Schefold 1997a, pp. 425-501.

(2000). "Paradoxes of capital and counterintuitive changes of distribution in an intertemporal model”. In: Kurz (ed.), pp. 363-91. 
Schwartz, Jesse (ed.) (1977). The Subtle Anatomy of Capitalism. Santa Monica, California, Goodyear Publishing Company.

Seton, Francis (1957): “The Transformation Problem”. The Review of Economic Studies, 24, pp. 149-160.

Shaikh, Anwar (1977): "Marx's Theory of Value and the 'Transformation Problem”, in Schwartz, Jesse (ed.) (1977), pp. 106-139.

(1981): "The Poverty of Algebra”, in Steedman, Ian and Sweezy, Paul (1981), pp. 266300 .

(1982): "Neo-Ricardian Economics: A Wealth of Algebra, A Poverty of Theory". The Review of Radical Political Economics, Vol. 12, n 2, Summer, pp. 67-83.

(1984): "The Transformation from Marx to Sraffa", in Mandel, Ernest and Freeman, Alan (1984), pp. 43-84 e 266-269.

(1990a): "Abstract and concrete labour", in Eatwell, John, Milgate, Murray and Newman, Peter (eds.) (1990a), pp. 42-44. Originalmente publicado em 1987.

(1990b): "Capital as a social relation", in Eatwell, John, Milgate, Murray and Newman, Peter (eds.) (1990a), pp. 72-78. Originalmente publicado em 1987.

(1990c): "Exploitation", in Eatwell, John, Milgate, Murray and Newman, Peter (eds.) (1990a), pp. 165-169. Originalmente publicado em 1987.

(1990d). "Market value and market price", in Eatwell, John, Milgate, Murray and Newman, Peter (1990), pp. 254-256. Originalmente publicado em 1987.

(1992). "Value and Value Transfers: A Comment on Itoh", in Roberts, Bruce and Feiner, Susan (1992), pp. 76-90.

(1998a). "The Empirical Strength of the Labour Theory of Value". In: Bellofiore, Riccardo (ed.) 1998b, pp. 225-251.

(1998b). Explaining Long Term Exchange Rate Behavior in the United States and Japan. Working Paper N $\mathrm{N}^{\mathrm{2}}$ 250, New York, New School for Social Research. (1999). Real Exchange Rates and the International Mobility of Capital. Working Paper $\mathrm{N}^{\mathrm{o}} 265$, New York, New School for Social Research.

Shaikh, Anwar, and Tonak, E. Ahmet. Measuring the Wealth of Nations. The Political Economy of National Accounts. Cambridge (US), Cambridge University Press, 1994. 
Smith, Adam (1983). A Riqueza das Nações. Investigação sobre sua Natureza e suas Causas. São Paulo, Abril Cultural. Originalmente publicado em inglês, em 1776.

Smith, Murray E.G. (1994a): “Alienation, Exploitation and Abstract Labor: A Humanist Defense of Marx's Theory of Value". Review of Radical Political Economics, Vol. 26, n 1, pp. 110133.

(1994b): Invisible Leviathan: The Marxist Critique of Market Despotism beyond Postmodernism. Toronto, University of Toronto Press.

Smith, Tony (1990). The Logic of Marx's Capital. New York, State University of New York Press. (1993). Dialectical Social Theory and its Critics - from Hegel to Analytical Marxism and Postmodernism. New York, State University of New York Press.

Sraffa, Piero (1985). Produção de Mercadorias por Meio de Mercadorias. In: Kalecki, Sraffa, Robinson. São Paulo, Editora Nova Cultural, Coleção Os Economistas, $2^{\mathrm{a}}$ edição, pp. 173258. Originalmente publicado em inglês, em 1960.

Steedman, Ian (1977): Marx after Sraffa. London, Verso.

Sweezy, Paul (1967): Teoria do Desenvolvimento Capitalista. Rio de Janeiro, Zahar Editores, $2^{\circ}$ edição. Originalmente publicado em inglês em 1942.

(org.) (1974): Economia Burguesa y Economia Socialista. Buenos Aires, Pasado y Presente, Siglo XXI Argentina Editores. Originalmente publicado em inglês em 1949.

(1974a): "Introducción" in Sweezy, Paul (org.) (1974), pp. 7-27. Originalmente publicado em inglês em 1949.

Toussaint, Eric (2002). A Bolsa ou a Vida. A divida externa do Terceiro Mundo: As finanças contra os povos. São Paulo, Editora Fundação Perseu Abramo. Originalmente publicado em francês, em 1998.

Valier, Jacques (1982). Une Critique de l'Economie Politique. Paris, Librairie François Maspero. 2 volumes.

Valle Baeza, Alejandro (1991). Valor y Precio: Una forma de regulación del trabajo social. México, Universidad Nacional Autónoma de México.

Veblen, Thorstein (1972). “Professor Clark’s Economics”. In: Hunt and Schwartz (eds.), pp. 172185.

Vianello, Fernando (1979). "El eslabón roto". In: Garegnani y otros (1979), pp. 65-74. Originalmente publicado em italiano, em 1978. 
de Vroey, Michel (1985). "La théorie marxiste de la valeur, version travail abstrait. Un bilan critique", in Dostaler et Laguex (dir.) 1985.

Weeks, John (1981). Capital and Exploitation. Princeton, Princeton University Press.

Wolff, Richard D., Roberts, Bruce and Callari, Antonino (1982). "Marx's (not Ricardo's) 'transformation problem': a radical reconceptualization". History of Political Economy, Vol. 14, No 4, Winter, pp. 564-582. (1984). "A Marxian Alternative to the Traditional 'Transformation Problem"'. Review of Radical Political Economics, Vol. 16, nº 2/3, Summer and Fall, pp. 115-135. (1998). “The Transformation Trinity: Value, Value Form and Price”. In: Bellofiore (ed.) 1998b, pp. 43-56.

Wood, John Cunningham (ed.) (1988). Marx's Economics: Critical Assessments. Vol. III, Marxian Economic Analysis. London, Croom Helm.

Yaffe, David (1975): "Valeur et prix dans Le Capital de Marx", Critiques de l'Économie Politique $\mathrm{n}^{\circ} 20$, avril-juin, pp. 45-103. (1994a): "Value, Price and the Neo-Ricardians: An Introductory Note", in Mohun, Simon (1994) (ed.), pp. 82-87. Originalmente publicado em 1973. (1994b): "Postscript" a 1994a, pp. 87-88.

Young, Gary (1976): “A Note on Marx Terminology”. Science and Society, Vol.40, No.1, Spring, pp. $72-78$. 